\title{
DISTRIBUIÇÃO DOS TIPOS DE CLASSE II, SUBDIVISÃO E AVALIAÇÃO DE SUAS ASSIMETRIAS
}

\section{KARINA JERÔNIMO RODRIGUES SANTIAGO DE LIMA}

Dissertação apresentada à Faculdade de Odontologia de Bauru da Universidade de São Paulo, como parte dos requisitos para obtenção do título de Mestre em Odontologia, área de Ortodontia.

(Edição Revisada)

\section{BAURU}




\section{DISTRIBUIÇÃO DOS TIPOS DE CLASSE II, SUBDIVISÃO E AVALIAÇÃO DE SUAS ASSIMETRIAS}

\section{KARINA JERÔNIMO RODRIGUES SANTIAGO DE LIMA}

Dissertação apresentada à Faculdade de Odontologia de Bauru da Universidade de São Paulo, como parte dos requisitos para obtenção do título de Mestre em Odontologia, área de Ortodontia.

(Edição Revisada)

Orientador: Prof. Dr. Guilherme Janson

\section{BAURU}




\section{KARINA JERÔNIMO RODRIGUES SANTIAGO DE LIMA}

21 de Agosto de 1974

Nascimento

João Pessoa - PB

1993-1997

Curso de Graduação em Odontologia pela Faculdade de Odontologia da Universidade Federal da Paraíba (UFPB).

1997-1999

Curso de Aperfeiçoamento em Ortodontia pela Assessoria e Consultoria de Ortodontia, Pesquisa e Ensino (ACOPEN).

$2001-2003$

Curso de Pós-graduação em Ortodontia, ao nível de Mestrado, pela Faculdade de Odontologia de Bauru - Universidade de São Paulo (FOB - USP).

Associação

Associação Paulista de Cirurgiões-Dentistas. 


\section{Lima, Karina Jerônimo Rodrigues Santiago de}

Distribuição dos tipos de Classe II, subdivisăo e avaliaçăo de suas assimetrias / Karina Jerônimo Rodrigues Santiago de Lima. - Bauru, 2003 .

170p. : il. ; $30 \mathrm{~cm}$.

Dissertaçăo (Mestrado) -- Faculdade de Odontologia de Bauru. Universidade de São Paulo.

Orientador: Prof. Dr. Guilherme Janson

funo $n: 1317120-0817103$

Autorizo, exclusivamente para fins acadêmicos e cientificos, a reproduçăo total ou parcial desta dissertaçăo, por processos fotocopiadores e outros meios eletrônicos.

Bauru, 28 de janeiro de 2003.

Assinatura: Karinayf Lloima

Projeto de Pesquisa aprovado pelo Comitê de Ética em Pesquisa da Faculdade de Odontologia de Bauru, Universidade de São Paulo, em 30 de março de 2001. 
E o sonho se confunde com os momentos sozinhos da jornada, da solidão cativa e horas de incerteza...

E a jornada finda como um sonho 6om, a certeza grata da vitória, o alívio transformado em lágrimas...

$E$ as reticências da continuidade preenchem a alma, embalando a vida que segue serena e segura, navegando...

Em mar de suor derramado nas agruras do tempo de um coração ofegante e repleto!

Feliz em estar vivo e sonhando...

Nilo Cesar Lima 
A DEUS, razão do meu viver, que além de me ter abençoado com uma família maravilhosa, deurme a oportunidade de vivenciar este momento tão especial e gratificante de minha vida profissional. Obrigada Senhor, por estar sempre presente em todos os momentos de minha vida, guiando-me por caminhos retos e iluminando-me na realização deste trabalho. 
Aos meus queridos pais, ORLANDINO e JURACY, com quem aprendi as mais belas lições de amor, carinho e dedicação. Agradeço por todo incentivo e apoio nos momentos e decisões mais importantes da minha vida, muitas vezes, abdicando de seus sonhos em prol dos meus. Considero-os um exemplo como casal, como pais e como colegas de profissão. A vocês, devo tudo, meu equilíbrio, minha formação profissional, minhas virtudes morais e espirituais. Não tenho palavras para expressar o imenso orgulho e alegria por tê-los como meus pais. Eu amo vocês! 
Ao meu esposo NILO CESAR, fonte incessante de amor, bondade, carinho, humildade, companheirismo, e outras tantas virtudes indescritíveis. O meu maior desafio foi, indubitavelmente, abdicar de nossa convivência diária, quando cada minuto de ausência parecia uma eternidade. Obrigada pelo incansável incentivo e imensurável paciência, confortando-me nas horas tristes, vibrando com as minhas vitórias. Sem o seu amor, nada valeria à pena! 
Aos meus queridos irmãos ALEXANDER, TATIANA e à minha primairmã ADRIANA KARLA, pelos fortes laços de amor e carinho que nos unem, cujas doces lembranças funcionam como um bálsamo, amenizando a saudade. Agradeço pelo estímulo constante, fortalecendo-me na busca dos meus ideais.

Com muito carinho, dedico-lhes este trabalho. 


\section{Agradecimentos especiais}

Aos meus avós JOÃO PAULO, ANTÔNIA E OTACíLIO, que já se encontram junto ao Pai e me deixaram tantas lembranças de dedicação e amor. À minha querida avó JOSEFA (vovó ZEFINHA) pelas suas orações e que, mesmo distante, faz-se muito presente, fortalecendo-me com suas sábias e carinhosas palavras.

À minha sogra MARIA DAS GRAÇAS (GRACINHA), a quem considero uma segunda mãe, pelo amor e carinho com que sempre me tratou. Agradeço a Deus pelos nossos laços tão íntimos de amizade e cumplicidade, incentivandome e apoiando-me no cumprimento desta jornada.

Aos meus cunhados ALBERTO CÉSAR (BETO), JÚLIO CÉSAR (JUCA), BRUNA, e IRAILTON, pela amizade, pelo carinho e consideração a mim dispensados.

Ao meu sobrinho JOÃO PAULO, a quem a distância me impossibilitou de acompanhar suas primeiras mudanças, seus primeiros passos. Espero que um dia entenda o quanto essa ausência foi difícil e compreenda o grande amor que sinto por você.

A toda minha FAMÍLIA, tios, tias e primos, pela confiança em mim depositada, por compartilharem a alegria de novas conquistas, por todo amor e incentivo.

Ao meu saudoso e querido tio ZECA, pelas boas recordações que deixou, que em muito nos influenciou com sua paixão pelos estudos e pela incessante busca do conhecimento.

Aos familiares do Nilo, em especial, os tios ELISON, ELISA e filhos, pela calorosa acolhida aqui em São Paulo, no seio de vossa família, adotando-nos como "netos". Obrigada por tanto carinho, dedicação e amor a nós oferecidos. 


\section{Agradecimento especial}

Ao Prof. Dr. GUILHERME JANSON,

Agradeço pela amizade, pela honra do convívio acadêmico, atenção e rigor no ensinar-me a arte de aos outros ensinar, o entusiasmo devotado à pesquisa e a clareza na orientação deste trabalho. 


\section{Agradecimentos}

Aos Professores Doutores DÉCIO RODRIGUES MARTINS, RENATO RODRIGUES DE ALMEIDA, JOSÉ FERNANDO CASTANHA HENRIQUES, MARCOS ROBERTO DE FREITAS e ARNALDO PINZAN, pelos valiosos conhecimentos e experiências transmitidas, para minha formação profissional em Ortodontia.

Aos PROFESSORES da Universidade Federal da Paraíba, responsáveis pela minha formação acadêmica que contribuíram para o meu aprimoramento moral, científico e intelectual.

Aos amigos do Curso de Mestrado ANALU, ANGELA, CELSO, CRISTINA YUKA, DANIELE, LENIANA e RODRIGO, nós formamos uma turma maravilhosa, destacando-se pela união e cumplicidade. Estes dois anos foram, indiscutivelmente, de grande aprendizado, tanto no âmbito profissional, quanto no pessoal em que compartilhamos momentos alegres e tristes, já eternizados em meu coração. Agradeço a Deus por ter convivido com todos vocês e por ter-me dado a capacidade de reconhecer em todos, os amigos que são e sua valiosa colaboração nesta jornada.

Aos alunos do Curso de Doutorado ADRIANO, ANA CARLA, ANA CLÁUDIA, DANIELA, DANILO, FAUSTO, KARINA CRUZ, KARYNA VALE, PAULO e RENATA, pela disponibilidade em nos auxiliar e pelo convívio fraterno.

Aos colegas do antigo Curso de Mestrado ADRIANA, CÉLIA, CLÁUDIA, DANIELE, DENISE, FÁBIO, FABRÍCIO, FERNANDA, JOSÉ EDUARDO, JOSÉ NORBERTO, KARINA, MARIA FERNANDA, REJANE e SANDRA, pela atenção e amizade.

Às inesquecíveis amigas e colegas de profissão JULIANA LEMOS (JULY), PATRÍCIA VASCONCELOS (PATY) e SÍLVIA CRISTINA (SILVINHA) que me 
acompanharam da escola até a Faculdade; a quem considero uma extensão da minha família, exemplos de amizade sincera e verdadeira que não se abala com a distância, nem com o tempo. Obrigada por torcerem para que esta etapa da minha vida se concretizasse e por todas as demonstrações de carinho.

À querida VIRGÍNIA FONTANA, que me deu a grande oportunidade de compartilhar de seus conhecimentos de Ortodontia, durante os anos que trabalhei em seu consultório e, muito além disso, honrou-me com uma grande amizade. Sinto-me feliz e orgulhosa em ser a sua madrinha de Crisma!

À amiga GISELLE MONTEIRO, companheira de estudo, para a prova de Mestrado, pela amizade, carinho e apoio em vários momentos desta trajetória ortodôntica.

Aos colegas pós-graduandos das demais Disciplinas desta Faculdade, pela proveitosa e animada convivência durante estes dois anos; em especial à ÉRIKA PETER, uma amiga sincera e muito especial com quem tive muitas afinidades, sou grata pela sua companhia, pelos momentos de descontração, pelas longas conversas.

Às amigas JANEYSA e ANDREZA pelos agradáveis momentos em nossas caminhadas, pelo carinho e incentivo constantes.

Aos casais amigos, RODRIGO e MICHELINE, FRANCI e SAMUEL, pelos maravilhosos momentos em que desfrutamos da sua companhia em São Paulo, fazendo-nos sentir mais perto de "casa", por todo apoio e consideração. 


\section{Agradeço ainda,}

À Faculdade de Odontologia de Bauru - Universidade de São Paulo, representada pela Digníssima Diretora Prof. Dra. MARIA FIDELA NAVARRO.

Ao Prof. Dr. JOSÉ CARLOS PEREIRA, Presidente da Comissão de PósGraduação da Faculdade de Odontologia de Bauru - Universidade de São Paulo.

Ao Prof. Dr. JOSÉ FERNANDO CASTANHA HENRIQUES, Prefeito do Campus da Faculdade de Odontologia de Bauru - Universidade de São Paulo, por proporcionar ambiente e infra-estrutura ideais para o aprimoramento científico e pessoal.

Ao Superintendente do Hospital de Reabilitação de Lesões Labiopalatais, Prof. Dr. JOSÉ ALBERTO DE SOUZA FREITAS (Tio Gastão) e à Prof. Dra. IZABEL MARIA MARCHI DE CARVALHO, responsável pelo Setor de Radiologia deste mesmo hospital, por ter permitido a utilização dos aparelhos de raios $\mathrm{X}$, para a obtenção das radiografias. Aos funcionários e residentes deste Setor, pelas orientações na utilização dos aparelhos e auxílios prestados.

Ao Prof. Dr. JOSÉ ROBERTO LAURIS, pela disponibilidade e paciência na orientação dos testes estatísticos.

Aos PACIENTES, fundamentais para minha formação e aprimoramento prático, possibilitando-me a realização deste trabalho.

Aos funcionários da Disciplina de Ortodontia CRISTINA, VERA, tia MARIA, SÉRGIO, como também ao DANIEL e ao FERNANDO por toda atenção, auxílio e amizade. Obrigada pela maneira carinhosa com que sempre me trataram. 
Aos funcionários da Pós-Graduação, em especial à Dona ANA, AURÉLIO e GIANE, pela delicada assistência e solicitude.

Aos funcionários da Biblioteca, pela eficiência, simpatia e pelas orientações valiosas, para a execução deste trabalho.

Aos funcionários da ACOPEN, CÉSAR, LUCIANA, SIMONE, SÔNIA e WALTER pelo carinho, amizade e presteza a mim dispensados.

À FAPESP, pela concessão de bolsa de estudos.

E a TODOS que, direta ou indiretamente, contribuíram para a realização deste trabalho. 


\section{SUMÁRIO}

LISTA DE FIGURAS

xviii

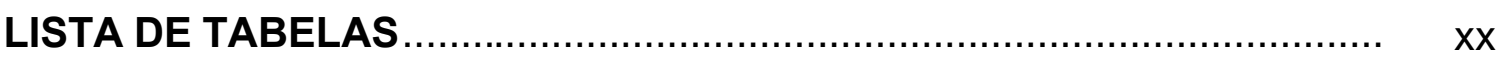

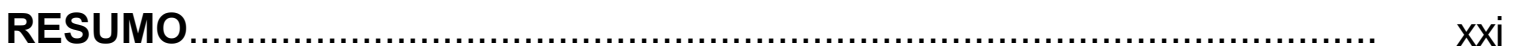

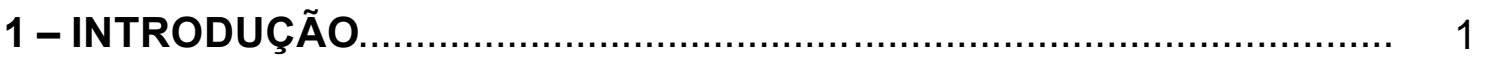

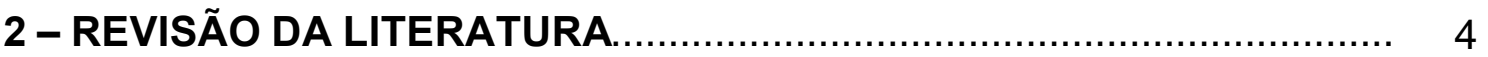

2.1 - A Assimetria craniofacial.................................................. 6

2.2 - A Assimetria craniofacial e as más oclusões............................ 10

2.3 - Etiologia da assimetria craniofacial...................................... 16

2.4 - A Classe II, subdivisão...................................................... 21

2.5 - Diagnóstico das más oclusões de Classe II, subdivisão................ 25

2.5.1 - Análise facial frontal.......................................................... 26

2.5 .2 - Radiografia Póstero-Anterior (PA) ..................................... 31

2.5.3 - Radiografia submentoniana............................................ 35

2.6 - Tipos de tratamento da Classe II, subdivisão............................ 39

2.6.1 - Tratamento ortopédico funcional da Classe II, subdivisão.......... 40

2.6.2 - Tratamento ortodôntico corretivo da Classe II, subdivisão.......... 41

2.6.2.1 - Mecânicas assimétricas empregadas na correção da Classe II, subdivisão.................................................................. 48

2.6.2.2 - Correção do desvio da linha média................................. 51

2.6.3 - Tratamento ortodôntico-cirúrgico das más oclusões assimétricas............................................................... 59

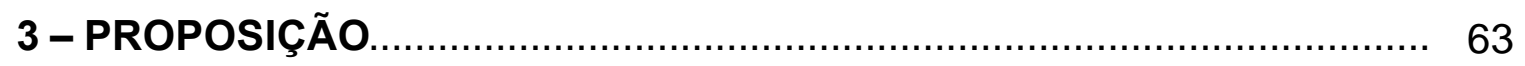

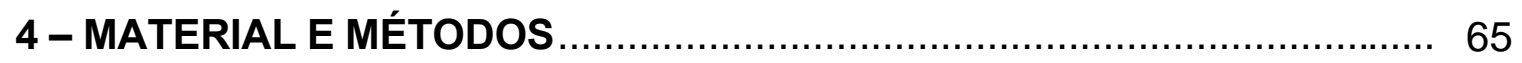


4.1 - Material.

4.2 - Métodos.

4.2.1 - Obtenção das Fotografias para classificação da Classe II, subdivisão, quanto aos tipos. 69

4.2.2 - Obtenção das Radiografias. 70

4.2.2.1 - Radiografias submentonianas 70

4.2.2.1.1 - Estruturas Anatômicas. 70

4.2.2.1.2 - Pontos de Referência. 71

4.2.2.1.3 - Linhas. 75

4.2.2.1.4 - Grandezas Cefalométricas 76

4.2.2.1.4.1 - Sistema de coordenadas mandibulares. 77

4.2.2.1.4.1.1 - Ântero-posterior. 77

4.2.2.1.4.1.2 - Transverso 78

4.2.2.1.4.2 - Sistema de coordenadas do assoalho craniano. 78

4.2.2.1.4.2.1 - Ântero-posterior. 78

4.2.2.1.4.2.2 - Transverso. 79

4.2.2.1.4.3 - Sistema de coordenadas do complexo zigomaticomaxilar 80

4.2.2.1.4.3.1 - Ântero-posterior. 80

4.2.2.1.4.3.2 - Transverso 80

4.2.2.1.4.4 - Sistema de coordenadas dentárias.. 81

4.2.2.1.4.4.1 - Ântero-posterior. 81

4.2.2.1.4.4.2 - Transverso. 82

4.2.2.1.4.5 - Medidas angulares entre as abscissas dos sistemas de coordenadas. 82

4.2.2.1.4.6 - Variáveis adicionais. 82

4.2.2.1.4.7 - Diferenças entre medidas bilaterais. 83

4.2.2.1.4.7.1 - Coordenadas mandibulares......................................... 83

4.2.2.1.4.7.1.1 - Ântero-posterior............................................................ 83

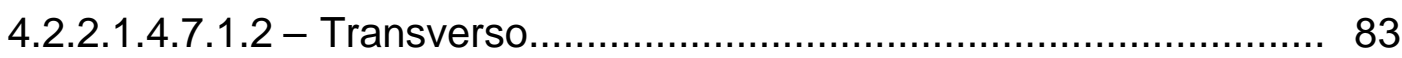

4.2.2.1.4.7.2 - Coordenadas do assoalho craniano.............................. 83

4.2.2.1.4.7.2.1 - Ântero-posterior........................................................ 83

4.2.2.1.4.7.2.2 - Transverso .......................................................... 84 
4.2.2.1.4.7.3 - Complexo zigomaticomaxilar.......................................... 84

4.2.2.1.4.7.3.1 - Ântero-posterior......................................................... 84

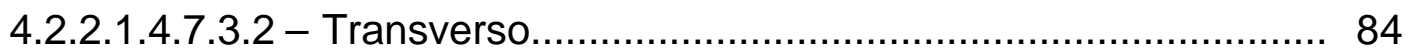

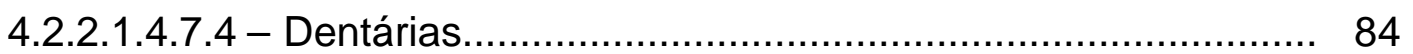

4.2.2.1.4.7.4.1 - Ântero-posterior........................................................ 84

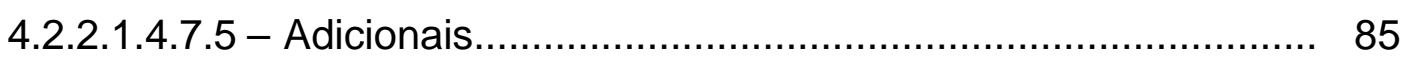

4.2.2.2 - Radiografias póstero-anteriores..................................... 98

4.2.2.2.1 - Estruturas anatômicas....................................................... 98

4.2.2.2.2 - Pontos de referência......................................................... 99

4.2.2.2.3 - Linhas e Planos............................................................ 101

4.2.2.2.4 - Grandezas Cefalométricas............................................... 102

4.2.2.2.4.1 - Diferenças entre medidas bilaterais................................ 104

4.2.3 - Erro do Método................................................................ 110

4.2.4 - Avaliação da distribuição dos tipos de Classe II, subdivisão....... 110

4.2.5 - Análise Estatística................................................................ 111

4.2.5.1 - Estatística Descritiva ....................................................... 111

4.2.5.2 - Comparação entre os grupos.................................................. 111

5 - RESULTADOS

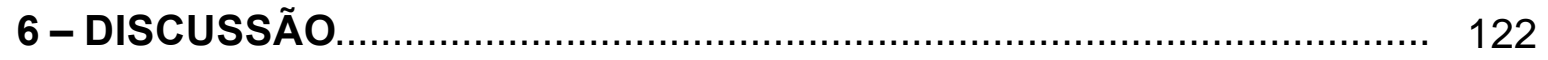

6.1 - Amostra Selecionada............................................................. 123

6.2 - Metodologia Empregada..................................................... 125

6.3 - Considerações sobre a Mensuração das Grandezas

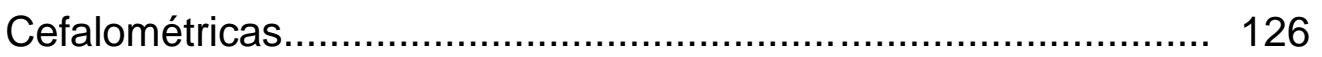

6.4 - Precisão da Metodologia....................................................... 127

6.5 - Distribuição dos tipos de Classe II, subdivisão............................. 128

6.6 - Resultados Obtidos nas Radiografias Submentonianas................. 130

6.6.1 - Sistema de Coordenadas Mandibulares................................... 131

6.6.2 - Sistema de Coordenadas do Assoalho Craniano......................... 132

6.6.3 - Sistema de Coordenadas Zigomaticomaxilares......................... 133

6.6.4 - Sistema de Coordenadas Dentárias.......................................... 134 
6.6.5 - Medidas Angulares

6.6.6 - Variáveis Adicionais. 137

6.7 - Resultados Obtidos nas Radiografias Póstero-Anteriores 137

6.8 - Considerações gerais. 139

6.9 - Considerações clínicas sobre o tratamento da Classe II, subdivisão

7 - CONCLUSÕES

ABSTRACT

\section{APÊNDICES}




\section{LISTA DE FIGURAS}

FIGURA 1 - Caso com Classe II, subdivisão

FIGURA 2 - Caso com oclusão normal

FIGURA 3 - Análise facial frontal

FIGURA 4 - Estruturas anatômicas da radiografia submentoniana

FIGURA 5 - Pontos da radiografia submentoniana.

FIGURA 6 - Linhas da radiografia submentoniana

FIGURA 7 - Grandezas cefalométricas da radiografia submentoniana Sistema de Coordenadas Mandibulares - Ântero-Posterior... 89

FIGURA 8 - Grandezas cefalométricas da radiografia submentoniana Sistema de Coordenadas Mandibulares - Transverso.

FIGURA 9 - Grandezas cefalométricas da radiografia submentoniana Sistema de Coordenadas do Assoalho Craniano - ÂnteroPosterior.

FIGURA 10 - Grandezas cefalométricas da radiografia submentoniana Sistema de Coordenadas do Assoalho CranianoTransverso.

FIGURA 11 - Grandezas cefalométricas da radiografia submentoniana Sistema de Coordenadas do Complexo Zigomaticomaxilar Ântero-Posterior. 
FIGURA 12 - Grandezas cefalométricas da radiografia submentoniana Sistema de Coordenadas do Complexo Zigomaticomaxilar

- Transverso.

FIGURA 13 - Grandezas cefalométricas da radiografia submentoniana Sistema de Coordenadas Dentárias - Ântero-posterior e Transverso. 95

FIGURA 14 - Grandezas cefalométricas da radiografia submentoniana Medidas Angulares entre as abscissas dos Sistemas de Coordenadas. 96

FIGURA 15 - Grandezas cefalométricas da radiografia submentonianaVariáveis Adicionais. 97

FIGURA 16 - Estruturas anatômicas da radiografia póstero-anterior 105

FIGURA 17 - Pontos da radiografia póstero-anterior. 106

FIGURA 18 - Linhas e planos da radiografia póstero-anterior 107

FIGURA 19 - Grandezas angulares da radiografia póstero-anterior 108

FIGURA 20 - Grandezas lineares da radiografia póstero-anterior. 109 


\section{LISTA DE TABELAS}

Apresentação dos erros casuais (DAHLBERG43), e dos resultados do teste t para amostras dependentes, das diferenças entre as replicações, do teste intra-examinador

TABELA 1 - Sistema de Coordenadas Mandibulares................................... 113

TABELA 2 - Sistema de Coordenadas do Assoalho Craniano....................... 114

TABELA 3 - Sistema de Coordenadas Zigomaticomaxilares........................ 114

TABELA 4 - Sistema de Coordenadas Dentárias....................................... 115

TABELA 5 - Medidas Angulares........................................................ 115

TABELA 6 - Variáveis adicionais....................................................... 116

TABELA 7 - Radiografia Póstero-Anterior................................................ 116

TABELA 8 - Tabela de distribuição dos tipos de Classe II, subdivisão.......... 117

TABELA 9 - Tabela de concordância da avaliação dos tipos de Classe II, subdivisão

Resultados do teste $t$ independente, entre os grupos de Oclusão Normal e de Classe II, subdivisão - tipos 1 e 2

TABELA 10 - Sistema de Coordenadas Mandibulares................................ 118

TABELA 11 - Sistema de Coordenadas do Assoalho Craniano.................... 118

TABELA 12 - Sistema de Coordenadas Zigomaticomaxilares...................... 119

TABELA 13 - Sistema de Coordenadas Dentárias....................................... 119

TABELA 14 - Medidas Angulares....................................................... 120

TABELA 15 - Variáveis adicionais....................................................... 120

TABELA 16 - Radiografia Póstero-Anterior............................................... 121 
Resumo 


\section{RESUMO}

O objetivo principal deste trabalho foi determinar, por meio de avaliação em fotografias frontais sorrindo, a distribuição dos tipos principais de Classe II, subdivisão. Secundariamente, estes subgrupos foram comparados com um grupo de oclusão normal, para investigar a ocorrência de assimetria dentoesquelética, utilizando-se radiografias submentonianas e póstero-anteriores. $\mathrm{O}$ grupo experimental consistiu de 44 indivíduos que apresentavam má oclusão de Classe II, subdivisão, com idade média de 15,3 anos. O grupo controle consistiu de 30 indivíduos que apresentavam oclusão normal, com idade média de 22,42 anos. Todos apresentavam os dentes permanentes superiores e inferiores, em ambos os arcos dentários, até os primeiros molares e que não haviam sido submetidos a tratamento ortodôntico. A Classe II, subdivisão do tipo 1 apresenta uma coincidência da linha média dentária superior com a linha média facial e desvio da linha média dentária inferior. O tipo 2 apresenta características opostas. Duas examinadoras realizaram uma avaliação subjetiva das fotografias frontais. Para a avaliação da simetria, medidas de diferenças relativas da posição espacial de pontos dentários e esqueléticos bilaterais foram obtidas nas radiografias submentoniana e pósteroanterior. Utilizourse $o$ teste $t$ independente para a comparação das assimetrias dentoesqueléticas entre os subgrupos de Classe II, subdivisão, tipos 1 e 2 com o grupo de oclusão normal. Os resultados demonstraram que $61,36 \%$ dos casos de Classe II, subdivisão foram do tipo 1; 18,18\% foram do tipo 2 e 20,45\% foram considerados duvidosos. Os dois subgrupos de Classe II, subdivisão apresentaram um grau de assimetria esquelética semelhante ao grupo de oclusão normal. Portanto, concluiu-se que os principais componentes que contribuem para a relação ântero-posterior assimétrica na Classe II, subdivisão, tipos 1 e 2 são dentoalveolares. 
1. Introdução

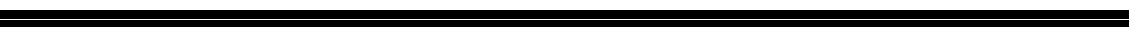




\section{1 - Introdução}

Muitos trabalhos publicados na literatura já verificaram que a Classe II, subdivisão resultaria principalmente de uma assimetria de posição dos molares inferiores, situados mais para posterior no lado da Classe II, do que no lado da Classe R,79,141. Em 1998, verificourse que os componentes mais freqüentes que contribuem para a relação ântero-posterior assimétrica na Classe II, subdivisão eram dentoalveolares, sendo que a principal diferença entre a má oclusão de Classe II, subdivisão e a oclusão normal consistiu na posição mais para distal do primeiro molar inferior do lado da Classe II, em uma base óssea com assimetria normal. Uma diferença secundária consistiu na posição mais para mesial do primeiro molar superior, no lado da Classe II. Portanto, concluise pela existência de dois tipos distintos de Classe II, subdivisão79. Como conseqüência, a linha média dentária inferior também apresenta um desvio mais freqüente para o lado da Classe II, do que a linha média dentária superior, no sentido oposto ${ }^{79}$. Estes estudos demonstraram portanto que as assimetrias presentes nos casos de Classe II subdivisão são principalmente dentoalveolares, sem a participação de assimetrias esqueléticas mandibulares. Entretanto, essas conclusões foram derivadas de trabalhos que incluíram os dois tipos de subdivisão acima descritos, associados. Isso gerou especulações de que as assimetrias dentoesqueléticas possam ser melhor evidenciadas se esses subgrupos de Classe II, subdivisão forem comparados individualmente com um grupo de oclusão normaß1.

Cada tipo de Classe II, subdivisão requer um planejamento de tratamento específico, de acordo com suas características. A literatura recomenda para o primeiro tipo (causado pela posição distalizada do molar inferior no lado da Classe II), os seguintes possíveis tratamentos: uma das melhores opções consistirá da extração de dois pré-molares superiores e de um pré-molar inferior do lado da Classe $\{, 29,35,36,82,174$, desde que o perfil do paciente permita certa retração dos incisivos superiores e dos incisivos inferiores. Para pacientes com assimetria subclínica ${ }^{38}$, cujo perfil não permita o esquema de extrações e uma certa quantidade de retração conseqüente, o tratamento basicamente consistirá em se obter a correção ântero-posterior do lado da Classe II, com a utilização de elásticos de Classe II unilaterais. Para o segundo tipo (causado pela posição mesializada do molar superior no lado da 
Classe II), os seguintes protocolos de tratamento podem estar indicados: extração de apenas um pré-molar superior do lado da Classe II, terminando com uma relação molar de Classe II desse lado, mas com as linhas médias dentárias coincidentes entre si e com o plano sagital mediano. Casos de pacientes em crescimento e que sejam colaboradores, podem admitir a correção com a utilização de forças extrabucais assimétricas.

Assim, seria interessante se conhecer a porcentagem desses principais tipos de subdivisão existentes, de forma a melhor orientar o clínico em seus planejamentos. Adicionalmente, os subgrupos de Classe II, subdivisão serão comparados individualmente com um grupo de 30 indivíduos com oclusão normal, com a finalidade de investigar as especulações acima de que as assimetrias esqueléticas mandibulares poderão ser evidenciadas, quando essa má oclusão é assim dividida. 
2. Revisão da Literatura 


\section{2 - Revisão da Literatura}

Com o intuito de facilitar a compreensão do texto e tornar a leitura mais agradável, dividiu-se este capítulo que revisa a literatura pertinente ao assunto deste trabalho nos seguintes tópicos:

2.1 - A Assimetria craniofacial

2.2 - A Assimetria craniofacial e as más oclusões

2.3 - Etiologia da assimetria craniofacial

2.4 - A Classe II, subdivisão

2.5 - Diagnóstico das más oclusões de Classe II, subdivisão

2.5.1 - Análise facial frontal

2.5.2 - Radiografia Póstero-Anterior (PA)

2.5.3 - Radiografia submentoniana

2.6 - Tipos de tratamento da Classe II, subdivisão

2.6.1 - Tratamento ortopédico funcional da Classe II, subdivisão

2.6.2 - Tratamento ortodôntico corretivo da Classe II, subdivisão

2.6.2.1 - Mecânicas assimétricas empregadas na correção

da Classe II, subdivisão

2.6.2.2 - Correção do desvio da linha média

2.6.3 - Tratamento ortodôntico-cirúrgico das más oclusões assimétricas 
Sabe-se que aproximadamente $50 \%$ de todas as más oclusões de Classe II constituem-se de subdivisões 5,171 , desta forma, convém avaliar a localização e a quantidade da assimetria, como forma de auxiliar no tratamento ortodôntico. Deve-se identificar os fatores responsáveis pela má oclusão e se a origem da assimetria é predominantemente dentoalveolar, esquelética ou uma combinação de ambas.

\section{1 - A Assimetria craniofacial}

Percebe-se a assimetria na região craniofacial como uma variação no tamanho ou no relacionamento das estruturas bilaterais da face. A causa do desequilíbrio pode estar na própria forma dos diferentes ossos, ou no posicionamento desfavorável de um osso ou das estruturas faciais. Por outro lado, o esqueleto facial pode se apresentar sem assimetria e o desequilíbrio concentrar-se, apenas, nos tecidos moles sobrejacentes ${ }^{19}$. As assimetrias das estruturas craniofaciais podem ter efeitos secundários na dentição e na oclusão, podendo apresentar problemas clínicos maiores associados, quando são do tipo severo 38 .

WOO182, em 1931, analisou 63 medidas em cada um dos 800 egípcios estudados e constatou que os ossos do crânio do lado direito exibiam uma assimetria, denotando que este lado demonstrava um maior tamanho conseqüente ao maior desenvolvimento do hemisfério cerebral direito. O lado contralateral do complexo facial exibia uma maior assimetria, apresentando um maior tamanho na região do arco zigomático e da hemimaxila esquerda, apesar do terço inferior do esqueleto facial não ter sido investigado.

Em sua monografia realizada em 1932, LUDWIG ${ }^{100}$ citou que os destros apresentam-se numa freqüência de $95 \%$ e os sinistros em aproximadamente $5 \%$, entre os humanos. Para cada caso, há uma tendência de se utilizar o lado direito ou esquerdo do corpo, sugerindo haver uma assimetria do sistema nervoso central. Corroborando esta proposição, afirmou que o centro da fala situa-se no hemisfério cerebral esquerdo nas pessoas destras e no direito, nas sinistras. Morfologicamente, as diferenças entre os lados direito e esquerdo se refletem no comprimento dos braços e das pernas; o braço direito é mais longo que o esquerdo e a perna direita mais curta que a esquerda. Dessa forma, mesmo em relação às partes do corpo que se assemelham essencialmente em 
estrutura em cada lado, a assimetria sistemática constitui num fenômeno comum.

BJÖRK; BJÖRK20, em 1964, estudando 149 crânios adultos do Peru, verificaram que a deformação occipital usualmente resultava em um menor tamanho da base do crânio no lado mais deformado, posicionando a cavidade glenóide mais anteriormente deste mesmo lado. Concluíram que a linha média facial não desenvolve uma assimetria de maneira análoga à base do đânio porque o crescimento maxilomandibular é inferior, no lado deformado. Segundo estes autores, este efeito referiurse a uma assimetria compensatória dos maxilares, diferentemente da assimetria displásica que promove uma hipo ou hiperplasia unilateral do côndilo mandibular.

Em 1971, ENLOW; KURODA; LEWIS 47 afirmaram que uma alteração em alguma porção do complexo craniofacial produz uma alteração igual em outra parte e, algumas vezes, em sentido contrário. Devido à habilidade individual intrínseca para compensar alterações de crescimento regionais, uma alteração relevante em uma parte anatômica não impede necessariamente o desenvolvimento de proporções faciais harmoniosas.

Comumente, utilizam-se as mensurações do esqueleto craniofacial em humanos, em crânios ou em radiografias cefalométricas no estudo do crescimento e desenvolvimento facial, das bases apicais e dos arcos dentários. VIG; HEWITT172, em 1975, desenvolveram uma metodologia para a análise da assimetria facial, comparando-se os lados direito e esquerdo, por meio de radiografias póstero-anteriores. Desta forma, os 63 jovens selecionados não poderiam apresentar nenhum grau de assimetria e nem desarranjos dentários. A faixa etária desta amostra variou entre 9 a 18 anos, com idade média de 14 anos, sendo 20 jovens do gênero masculino e 43 do gênero feminino. Após a realização dos traçados cefalométricos, concluíram que as regiões da base do crânio e da maxila exibiam uma assimetria predominantemente maior do lado esquerdo, enquanto a mandíbula e as regiões dentoalveolares apresentavam um maior grau de simetria.

Para avaliar a assimetria do complexo craniofacial normal, SHAH; JOSHI152, em 1978, selecionaram 43 jovens. A amostra constava de 29 pacientes do gênero masculino e 14 do gênero feminino, com idade média de 21 anos e seis meses. Para este estudo, utilizaram radiografias póstero- 
anteriores de pacientes com os dentes em oclusão cêntrica apresentando faces simétricas clinicamente e oclusão normal. Concluíram que a assimetria pode estar presente mesmo $œ$ os dentes apresentam um excelente contato oclusal, máxima intercuspidação e linhas médias dentárias superiores e inferiores coincidentes. Além disso, verificaram que as estruturas da face são significantemente maiores no lado direito do que no lado esquerdo e que uma das possíveis causas para a produção da assimetria relacionava-se ao hábito de mastigação unilateral. Como as forças mastigatórias são transmitidas dos dentes para os ossos do crânio e da face, estes autores observaram que a maioria dos jovens mastigava mais do lado direito do que do lado esquerdo, constituindo-se num dos possíveis fatores responsáveis pelo lado direito ser maior que o esquerdo, neste trabalho. Afirmaram também que as faces simétricas e harmoniosas podem exibir uma assimetria esquelética, estando esta assimetria minimizada pelos tecidos moles.

Em 1981, CHEBIB; CHAMMA 34 avaliaram a assimetria craniofacial de 64 adultos leucodermas de ambos os gêneros por meio da radiografia pósteroanterior. Oito pontos ímpares localizados na linha mediana e 12 pontos pares laterais foram selecionados para o método matemático de mensuração da assimetria craniofacial pelo sistema de coordenadas $\mathrm{X}$ e $\mathrm{Y}$. Verificaram uma menor freqüência da assimetria na região mediana do que nas laterais e nenhuma diferença significante foi encontrada com relação ao gênero. As estruturas da região dentoalveolar mediana da maxila, a porção inferior do nariz e o mento mostram grandes desvios estatísticos dentre todas as estruturas analisadas. Uma significante assimetria horizontal do lado esquerdo estava presente nas estruturas ósseas, com comprometimento muscular associado: temporal (músculo temporal), côndilo (pterigóideo lateral), maxila (bucinador), zigoma (músculos zigomáticos), osso mastóideo (esternocleidomastoideo) e região goníaca (masseter e pterigóideo medial). Concluíram que existe uma diferença entre as estruturas craniofaciais dos lados esquerdo e direito, sendo que o lado esquerdo apresenta uma maior assimetria horizontal e menor assimetria vertical, apesar destes dados necessitarem de mais pesquisas para sua confirmação.

Os estudos de KANTOMAA86, em 1989, assim como os de PIRTTINIEMI; KANTOMAA; RONNING ${ }^{131}$, em 1990, verificaram uma relação 
próxima entre a morfologia da superfície articular da fossa glenóide e a morfologia mandibular, influenciando no desenvolvimento de discrepâncias esqueléticas e más oclusões.

Em 1991, PECK; PECK; KATAJA ${ }^{126}$, utilizaram a radiografia pósteroanterior, para estudar a intensidade e variabilidade da assimetria craniofacial subclínica em 52 adultos leucodermas com bom equilíbrio facial, sendo 49 do gênero feminino e 3 do gênero masculino, com idade média de 21 anos e 2 meses. A determinação da assimetria esquelética foi realizada por meio de três medidas bilaterais esqueléticas que foram: órbita látero-superior, zygoma e gônio. A diferença entre os lados esquerdo e direito da hemiface foi quantificada em milímetros para que se calculasse a largura total entre os pontos bilaterais. Os resultados revelaram que houve uma ligeira dominância para o lado direito, embora não tenha sido estatisticamente significante. Os resultados sugerem que o complexo craniofacial exibe menor assimetria e maior estabilidade dimensional à medida que se aproxima do crânio, e validam o uso do ponto cefalométrico orbital látero-superior como ponto de referência craniano estável no cefalograma frontal.

Ainda em 1991, TALLENTS et al.168 comentaram que a assimetria mandibular geralmente relaciona-se com uma hiperplasia condilar unilateral associada a um crescimento acelerado. Comentaram que as conseqüências das assimetrias mandibulares poderiam ser a mordida aberta, o desvio da linha média mandibular em direção contrária ao maior lado, a inclinação do plano oclusal e a mordida cruzada do lado mais curto. As alterações faciais mais comuns são o desvio do mento, em sentido contrário ao lado mais longo ou proeminência ou achatamento da região goníaca. Concluíram que o ângulo goníaco geralmente se encontra mais agudo no lado mais comprido.

Objetivando estudar a assimetria na forma e localização da articulação temporomandibular e sua relação com a assimetria mandibulofacial, PIRTTINIEMI; KANTOMAA ${ }^{130}$, em 1992, analisaram 40 crânios adultos, de ambos os gêneros, sem defeitos estruturais morfológicos, representando um grupo racial uniforme do século XIX, pertencente ao Departamento de Anatomia, da Universidade de Helsinki, na Finlândia. Utilizaram radiografias submentonianas, laterais e póstero-anteriores cuja configuração da fossa era claramente definida. Os resultados mostraram uma assimetria 
temporomandibular direcional generalizada. A fossa glenóide do lado direito estava mais posicionada lateral e posteriormente do que a esquerda, quando analisada na visão axial. A mandíbula estava geralmente mais comprida no lado esquerdo do que do lado direito, na visão frontal. A assimetria temporomandibular encontrada neste estudo relacionava-se com as características da base do crânio $e$ as diferenças direita-esquerda do comprimento mandibular. A linha média dentária inferior estava mais desviada para a direita do que para a esquerda pela visão frontal, sugerindo uma tendência a uma oclusão normal, do lado direito e um comprimento mandibular maior para o lado esquerdo. Este aspecto relaciona-se com a assimetria condilar, uma vez que a superfície articular é mais íngreme no lado direito do que no esquerdo. A razão básica para o relacionamento assimétrico direcional vinculou-se com a interação recíproca entre o desenvolvimento assimétrico da base do crânio e a influência da função direcional.

\section{2 - A Assimetria craniofacial e as más oclusões}

A assimetria craniofacial ocorre freqüentemente na maioria da população, segundo alguns pesquisadores $20,36,125,176,182$, e independe da má oclusão53,95,101.

Em 1952, CHENEY35 esclareceu que podem haver vários tipos e combinações de desenvolvimento assimétrico, alguns deles envolvendo as estruturas profundas das bases apicais, enquanto que outros ocorrem nos arcos dentários. Há ainda outro grupo que resulta de diferenças em tamanho e forma dos arcos dentários opostos. Em muitos indivíduos, um lado da face é diferente do outro e, nesses casos, aconselha-se planejar o tratamento para resolver os problemas dentoesqueléticos, de acordo com a necessidade individual. Concluiu que nem todo tratamento ortodôntico deve ser realizado bilateralmente (simétrico), pois há assimetrias intrínsecas das bases apicais, existindo também as assimetrias entre as bases apicais e as desarmonias entre as formas dos arcos dentários.

Segundo FISHER ${ }^{53}$, em 1954, a assimetria facial não necessariamente interfere na obtenção da correta oclusão. Baseando-se nisto, pacientes com oclusão normal, apresentando as linhas médias superior e inferior coincidentes entre si apresentaram uma maior assimetria para o lado direito da face ${ }^{152}$. 
BRASH; MCKEAG22, em 1956, comentaram que a assimetria facial ocorre devido a uma assimetria de desenvolvimento do cérebro por razões funcionais ou devido a um hábito muscular assimétrico, como a mastigação unilateral.

Pesquisando sobre as assimetrias e sua significância clínica, CHENEY36, em 1961, relatou que existem quatro tipos de assimetrias dentofaciais que seriam resultantes de diferenças ântero-posteriores unilaterais, diferenças de altura (desarmonia vertical); diferenças laterais horizontais (deslocamentos laterais) e rotações do complexo maxilar ou do ramo mandibular, associadas ou não a variações de tamanho unilaterais. Verificou que todas estas alterações assimétricas atuariam afetando o tamanho, a forma e a posição das duas hemifaces direita e esquerda. Desenvolveu um método de identificação e descrição das assimetrias faciais, estabelecendo pontos anatômicos de referência para comparação entre os lados direito e esquerdo. Para tanto, utilizou fotografias extrabucais frontais, de perfil e da região mandibular numa visão axial para a análise das assimetrias dos tecidos moles. Posteriormente, radiografias póstero-anteriores e modelos de estudo foram obtidos para se avaliar as assimetrias esqueléticas e dos arcos dentários, respectivamente.

LETZER; KRONMAN95, em 1967, avaliando a inter-relação entre a oclusão dentária e a presença ou ausência de assimetria da base do crânio ou mandibular no plano frontal, compararam um grupo de 50 pacientes possuindo oclusão excelente com 50 pacientes apresentando más oclusões. O critério de determinação da oclusão excelente baseou-se em um relacionamento ânteroposterior normal dos arcos dentários, uma sobremordida normal, uma tolerância de apinhamento de no máximo três milímetros dos arcos dentários e um espaço interproximal inexistente ou mínimo. Os resultados desta investigação revelaram que não houve uma relação estatisticamente significante entre a oclusão e a simetria ou a assimetria da face. Entretanto, um grau significante de simetria, tanto na base craniana anterior como na mandíbula foi encontrado no grupo com oclusão normal. De modo contrário, ambos os grupos demonstraram uma assimetria, sugerindo-se que a assimetria facial constitui-se numa característica normal nos pacientes, sendo independente do tipo da má oclusão. 
Analisando a assimetria dos arcos dentários em pacientes com oclusão normal e com má oclusão, HECHTER69, em 1975, encontrou uma maior assimetria no arco inferior em ambos os grupos. Entretanto, verificou um aumento da assimetria, em ambos os arcos, quando a má oclusão estava presente. Por meio de funções matemáticas, pesquisas sobre a forma do arco dentário também demonstraram assimetrias $13,18,127$.

Realizando uma revisão da literatura sobre a assimetria do esqueleto craniofacial, $\operatorname{COOK}^{38}$, em 1980, afirmou que a anatomia craniofacial normal pode demonstrar graus variados de assimetria, desde a assimetria subclínica, compatível com a oclusão normal, até as assimetrias acentuadas, resultantes de causas traumáticas, patológicas ou do desenvolvimento. Comentou que a deformação do crânio pode ocorrer no útero, durante o nascimento ou na infância. Concluiu que provavelmente todas as estruturas craniofaciais demonstram algum grau de assimetria, sendo geralmente subclínica e compatível com a oclusão normal.

Mais tarde, PONYI; SZABÓ; NYILASI133, em 1991, objetivaram elucidar se havia diferenças entre os lados direito e esquerdo de 18 medidas mandibulares de crânios europeus, de ambos os gêneros, pertencentes aos séculos X e XII, que estavam soterrados no sudeste húngaro. Desenvolveram uma pesquisa em que encontraram uma diferença estatisticamente significante apenas para a menor dimensão sagital do pescoço mandibular, nos dois gêneros. Concluíram que a assimetria dos lados esquerdo e direito foi encontrada entre as dimensões mandibulares medidas individualmente em $41,4 \%$ dos crânios masculinos e 40,4\% dos crânios femininos.

MELNIK ${ }^{106}$, em 1992, avaliou uma amostra longitudinal de jovens com idades, variando entre 6, 9, 12, 14 e 16 anos, pertencente ao Centro de Crescimento de Burlington, Ontário; Canadá. Este autor objetivou analisar a assimetria mandibular e as medidas do ângulo goníaco de ambos os lados, de acordo com o gênero e a idade, por meio da comparação das diferenças obtidas entre os lados direito e esquerdo, nas radiografias oblíquas de $45^{\circ}$. Os resultados demonstraram que as assimetrias eram comuns em todas as idades. Um maior comprimento mandibular no lado direito, manifestando-se aos 12 anos no gênero feminino e somente aos 16 anos, no gênero masculino, idade em que 5 a $10 \%$ das jovens apresentavam assimetrias maiores do que 
$5 \mathrm{~mm}$. Embora o gênero masculino tenha demonstrado uma maior assimetria mandibular, apresentando maior comprimento em idades mais precoces, após os 14 anos não houve mais diferenças entre os gêneros. De modo contrário, diferenças significantes não existiram entre os ângulos goníacos dos lados direito e esquerdo, em relação ao gênero e à idade da amostra estudada.

Objetivando determinar se a simetria mandibular em adultos com mordida cruzada posterior unilateral denotava diferença daquela de adultos com más oclusões de Classe I, não tratadas, O'BYRN et al.118, em 1995, conduziram uma pesquisa em que 30 adultos, acima de 18 anos, com mordida cruzada posterior unilateral foram comparados com 30 adultos com más oclusões de Classe I. Obtiveram-se radiografias submentonianas para se avaliar as simetrias esquelética e dentária. Enquanto as tomografias horizontais corrigidas serviram para avaliar a posição condilar dentro da fossa glenóide. Em relação ao sistema de coordenadas mandibulares, o primeiro molar inferior, do lado da mordida cruzada, apresentava-se mais lateral e distalmente, em comparação com o do lado oposto. Esqueleticamente, a mandíbula não demonstrou assimetria. A mandíbula apresentourse rotacionada em relação ao assoalho craniano, de forma que o côndilo do lado da mordida cruzada estava posicionado posteriormente em relação ao lado oposto. Concluiu-se que havia uma posição posterior relativa da fossa glenóide, uma vez que não se observou nenhuma assimetria mandibular esquelética ou deslocamento condilar dentro da fossa, como evidenciado nas tomografias corrigidas no grupo com mordida cruzada, quando comparadas com as do grupo de Classe I. Os autores questionaram se seria correto corrigir mordidas cruzadas posteriores unilaterais em adultos apenas ortodonticamente, com a movimentação dentária, considerando-se que a remodelação óssea da fossa glenóide já possa ter ocorrido. Concluíram que as adaptações tanto na posição mandibular, relativas ao sistema de coordenadas do assoalho craniano, como na dentição, em relação ao sistema de coordenadas mandibulares, existem em adultos com mordida cruzada posterior não tratada. Com a correção do problema oclusal, há um aumento da possibilidade destas alterações ocorrerem dentro da fossa glenóide. As mudanças suaves da posição condilar relacionam-se com a capacidade adaptativa de alguns pacientes em tolerar 0 desconforto e a dor. 
Em 1998, PIRTTINIEMI129 afirmou que a assimetria normal na região do esqueleto craniofacial pode ser direcional ou flutuante. A direcional pode ser encontrada em três dimensões: ântero-posterior; craniocaudal e assimetrias nas dimensões direita e esquerda. Quando ocorre por diferença bilateral, sua justificativa torna-se complexa, apesar de se manifestar freqüentemente. Em geral, concluiu que quando a assimetria funcional aumenta com a idade, há uma dificuldade em se determinar a contribuição exata de cada fator etiológico envolvido. Também relatou que a influência da oclusão no desenvolvimento das estruturas faciais harmoniosas exerce suma importância durante os primeiros anos de vida.

SHEATS et al. ${ }^{154}$, em 1998, fizeram uma estimativa da magnitude de prevalência da assimetria dentária e facial em jovens americanos, sem história de tratamento ortodôntico prévio e compararam com os dados estatísticos de um grupo submetido ao tratamento ortodôntico. Concluíram que não há associações significantes entre a assimetria facial e a não coincidência das linhas médias. Entretanto, associações estatisticamente significantes foram encontradas em relação à assimetria do molar e a assimetria facial, a assimetria do molar e a não coincidência das linhas médias e a assimetria do molar e o tipo racial. Em virtude da deficiência metodológica para avaliação da assimetria, os resultados desta pesquisa não puderam ser considerados precisos. Para os autores, os examinadores não foram adequadamente calibrados e ainda, os pacientes avaliados não foram analisados quanto à presença de desvios da relação cêntrica para a oclusão cêntrica e, nem mesmo, com relação à coincidência das linhas médias.

LEGAN92, ainda neste ano, comentou que a mandíbula exerce uma contribuição dominante para a assimetria dentofacial já que forma o suporte esquelético dos tecidos moles da face inferior. De modo contrário, a maxila contribui com um suporte mínimo para os tecidos moles, apresentando pequena participação na assimetria. Afirmou também que a maioria das assimetrias maxilares é secundária ao crescimento mandibular assimétrico, podendo ser mensurada simplesmente pela localização da linha média dentária superior e pela inclinação do plano oclusal.

Também em 1998, SHROFF; SIEGEL159 comentaram que a fratura condilar na infância associa-se a um crescimento limitado, contribuindo, 
conseqüentemente, para o aparecimento da assimetria. À medida que o crescimento facial prossegue, a mandíbula progressivamente desvia-se para 0 lado afetado, ou, em alguns casos, pode ocorrer um crescimento compensatório excessivo no lado da fratura, hiperplasia condilar, produzindo uma assimetria com desvio mandibular para o lado oposto ao afetado. Quando a articulação temporomandibular sofre uma injúria, ocorre a formação de uma artrose intracapsular, apresentando grande potencial para produzir uma anquilose $\operatorname{articular}^{136}$. Além da presença da assimetria, uma restrição na abertura bucal se manifesta devido à falta do movimento de translação condilar no lado afetado. Uma assimetria maxilar compensatória, uma inclinação do plano oclusal e uma disfunção temporomandibular podem estar associadas a estas assimetrias. As doenças degenerativas articulares unilaterais predispõem ao aparecimento da assimetria. A reabsorção condilar progressiva, quando ocorre bilateralmente, associa-se a uma mordida aberta anterior e a uma retrognatia mandibular progressiva. Nos casos de reabsorção condilar unilateral, a assimetria agrava-se paulatinamente e o lado afetado vai se tornando cada vez mais Classe II $^{159}$.

FUSHIMA; INUI; SATO56, em 1999, avaliaram a assimetria dentária em pacientes com desordens temporomandibulares por meio de cefalogramas póstero-anteriores e de modelos de estudo. Examinourse o desvio lateral da linha média inferior, a diferença da relação molar em ambos os lados (direito e esquerdo) e sua relação com o deslocamento lateral da mandíbula. O desvio lateral da linha média inferior e a diferença da relação molar foram significantemente correlacionados com o deslocamento lateral da mandíbula. Em muitos casos, o lado do deslocamento da linha média inferior foi coincidente com a linha média mandibular esquelética. Estes resultados sugerem que nos pacientes com desordem temporomandibular as assimetrias na relação oclusal da linha média inferior e dos molares mantiveram-se de acordo com a assimetria esquelética mandibular. Muitos casos apresentaram uma relação oclusal mais distal do primeiro molar no lado deslocado da mandíbula quando comparado com o lado oposto. Encontrou-se uma alta incidência de relação de Classe II $(61,8 \%)$ e mais evidente no lado deslocado da mandíbula. A discrepância da linha média e a diferença na relação molar 
em ambos os lados apresentaram-se como uma característica oclusal importante nos pacientes com desordem temporomandibular.

\section{3 - Etiologia da assimetria craniofacial}

As más formações genéticas ou congênitas, como a microssomia hemifacial; fatores ambientais, como o trauma; desvios funcionais; desvios mandibulares resultantes de interferências dentárias; fatores epigenéticos e adquiridos, como infecções ou patologias geralmente incluem-se como causas das assimetrias dentofaciais 92 . Quando o crescimento mandibular de um lado aumenta ou diminui, comparando-se com o do lado oposto, desenvolve-se uma assimetria facial com desvio da linha média e do mento para um lado. Várias causas podem estar relacionadas, podendo a assimetria ser congênita ou adquirida.

A oclusão não somente é afetada pela posição dos dentes, mas também pelo padrão de crescimento esquelético. Um dos objetivos do controle do desenvolvimento oclusal e da correção da má oclusão consiste no estabelecimento de uma simetria da forma dos arcos individualmente e do relacionamento oclusal maxilomandibular. A simetria da forma dos arcos relaciona-se com as inclinações axiais e rotações dos dentes individualmente. As assimetrias mandibulares podem estar relacionadas não somente com uma posição assimétrica, como também em relação à morfologia assimétrica mandibular. Diferenças no comprimento do corpo mandibular, bem como, na altura do ramo podem-se relacionar com as assimetrias. O desenvolvimento de uma assimetria pode se iniciar na vida fetal, podendo também resultar de distúrbios do desenvolvimento pós-natal, como o trauma do côndilo mandibular89.

Em 1981, WILLIAMSON178 comentou que a assimetria ocorre freqüentemente devido a fatores genéticos, funcionais e traumáticos. Quando há assimetria, ocorre uma maior severidade da má oclusão de Classe II apenas de um lado, ocasionando uma Classe II, subdivisão. Afirmou também que quando o ortodontista trata em relação cêntrica, o plano de tratamento dos casos deve utilizar ancoragem máxima no arco superior, do lado deficiente. Em alguns casos severos, pode se chegar a uma relação de topo a topo, no lado mais curto da mandíbula, ao final do tratamento, considerando-se um sucesso. 
Quando se manipula a mandíbula em relação cêntrica, os dentes inferiores posicionam-se mais distalmente, comparando-se com os superiores, causando uma discrepância de linha média, com desvio mandibular para o lado deficiente, quando o côndilo se assenta. Como exemplo clínico, este autor citou um caso em que os elásticos assimétricos foram utilizados, não corrigindo a linha média. Relatou que, de um modo geral, 32\% dos pacientes apresentam $3 \mathrm{~mm}$ ou mais de assimetrias mandibulares que podem ser verificadas em radiografias póstero-anterior e submentoniana ${ }^{179}$. Três milímetros equiparamse aproximadamente à largura de uma cúspide, levando uma Classe I, em máxima intercuspidação, para uma Classe II, em relação cêntrica. As assimetrias aparentemente podem ocorrer por deficiência do corpo mandibular de um lado, visualizadas pela radiografia submentoniana, ou pela deficiência de crescimento vertical, quando evidenciadas pela radiografia póstero-anterior. Em ambos os casos, o relacionamento de molar e de canino é mais Classe II, no lado deficiente, quando verificado em modelos de gesso articulados. Uma discrepância de linha média pode ser uma indicação de uma assimetria, sugerindo que um lado da oclusão pode ser mais Classe II que o outro. Se uma assimetria está presente e o caso está sendo tratado com o conceito de posição assentada no côndilo, o profissional deve terminar o caso com um lado mais Classe II que o outro. WILLIAMSON178 comentou que as forças dos elásticos intermaxilares podem empurrar o côndilo para frente e para fora da posição de repouso, no lado da Classe II, havendo a correção da discrepância de linha média, mas um côndilo não fica totalmente assentado. Se nenhum crescimento compensatório ocorre, a discrepância de linha média pode ser corrigida, porém um côndilo não fica assentado, havendo a produção de uma deflexão da oclusão de relação cêntrica até a máxima intercuspidação. Concluiu que nos problemas de linha média devido às discrepâncias de tamanho dentário, o plano de tratamento pode envolver extrações assimétricas, quando o caso permitir, ou aceitação do problema, em casos sem extração, com indicação de ajuste oclusal ao final do tratamento.

A relação entre a assimetria da linha média facial adquirida e 0 deslocamento de disco em jovens foi descrita por SCHELLHAS; POLLEI; WILKES ${ }^{148}$, em 1993, enquanto WESTESSON et al. ${ }^{175}$, em 1994, avaliou esta mesma questão, em adultos. Entretanto, em ambos os trabalhos, não foi 
relatado se a assimetria predispõe ao desenvolvimento de deslocamento de disco da articulação temporomandibular, ou se este deslocamento pode causar desvio mandibular, durante o crescimento.

SKOLNICK et al. ${ }^{163}$, em 1994, utilizando a radiografia póstero-anterior como método de identificação da assimetria mandibular, avaliaram 56 casos cirúrgicos e 109 casos ortodônticos buscando a inter-relação entre o trauma pré-pubescente e o desenvolvimento da assimetria mandibular. Verificaram uma associação estatisticamente significante entre a história de trauma prépubescente e a assimetria mandibular, por meio das radiografias frontais tanto nos casos cirúrgicos como no grupo de pacientes ortodônticos. Nos casos cirúrgicos, a história de trauma facial pré-pubescente foi constatada em 6 pacientes, sendo que todos apresentavam assimetria mandibular, enquanto que no grupo dos pacientes ortodônticos, 20 jovens apresentavam história de trauma e 11 apresentavam assimetria mandibular. Finalmente, concluíram que existe uma associação estatisticamente significante entre a evidência radiográfica de assimetria mandibular e a história de trauma facial prépubescente.

A maior causa da assimetria severa em jovens pré-pubescentes consiste na anquilose da ATM e limitação do seu movimento, resultante da fratura condilar unilateral. Quanto maior o grau de inibição da mobilidade associada ao crescimento ativo, mais rápida e severa será a assimetria. A anquilose óssea da ATM pode produzir uma assimetria tridimensional facial, envolvendo ambos os maxilares, sendo um grande desafio cirúrgico. Em adição, os desarranjos internos unilaterais da ATM com ou sem história prévia de fratura condilar mandibular podem ser a causa principal da assimetria facial. A microssomia hemifacial consiste numa causa comum da assimetria facial em jovens, apresentando uma deformação típica da orelha e do ramo mandibular, com côndilo e tecidos moles associados inadequados ou ausentes ${ }^{92}$.

A perda prematura dos molares decíduos causa rotação e inclinação axial anormal dos primeiros molares superiores permanentes que se constituem fatores determinantes da assimetria dentária. A mesialização com inclinação para anterior dos molares permanentes resulta em perda significante de espaço na porção posterior do arco dentário. Outro fator desta rotação seria a erupção ectópica mesial do molar. Durante o desenvolvimento, as coroas dos 
molares superiores estão voltadas para distal e durante o crescimento, quando a maxila se desloca para frente e para baixo, os molares superiores se verticalizam, ficando suas coroas voltadas para oclusal. Comentaram que uma rotação mesial do molar superior resulta numa relação de molar de Classe II mais acentuada no lado afetado. Pela vista oclusal, os arcos podem ser avaliados quanto à simetria, pela rafe mediana e sua projeção no arco mandibular por meio de uma estrutura plástica transparente sobreposta à superfície oclusal dos dentes. A maneira mais eficiente de se avaliar a rotação dos molares consiste em desenhar uma linha ao longo da superfície mesial do molar em cada lado do arco e observar o ponto de intersecção destas duas linhas ${ }^{159}$.

Em 1999, LEGRELL; ISBERG94 propuseram-se a pesquisar se 0 deslocamento de disco da ATM causa desvio mandibular e o desenvolvimento da assimetria da linha média mandibular em coelhos durante o período de crescimento. Estudos experimentais em coelhos68,168 devem ser considerados relevantes porque o mesmo padrão de desvio mandibular durante 0 crescimento após a restrição de movimento mandibular tem sido registrado em seres humanos 76 e em macacos ${ }^{77}$, indicando que não há diferença entre estas espécies a respeito do impacto da função mandibular alterada no padrão de crescimento mandibular. Desta forma, concluíram que o deslocamento de disco, não tratado, em coelhos em período de crescimento provoca a assimetria do comprimento mandibular com desvio da linha média para o lado ipsilateral.

SJURSEN; LEGAN; WERTHER ${ }^{161}$, ainda em 1999, publicaram um caso clínico de uma jovem de 28 anos com assimetria facial conseqüente a um trauma na infância, mencionando que este fator poderia ter implicado no desenvolvimento desta assimetria. Pela análise dentária, a paciente apresentava uma Classe II, com sete milímetros de sobressaliência, mordida aberta anterior, desvio da linha média dentária inferior para o lado esquerdo e deslocamento mandibular para a direita, durante o movimento de abertura de boca. Diagnosticou-se também um excesso vertical da maxila acompanhado de uma deficiência do arco superior, no sentido transverso e uma assimetria mandibular do lado esquerdo, além da presença de um desnivelamento da órbita esquerda, constatado pela análise facial. Concluíram que o trauma pré-- 
pubescente geralmente está vinculado como uma das causas do crescimento mandibular assimétrico.

Neste mesmo ano, KONDO; AOBA 87 , afirmaram que a função anormal do músculo cervical pode causar uma postura anormal da cabeça, afetando desfavoravelmente o desenvolvimento e a morfologia da coluna cervical e do esqueleto maxilofacial, o que induz à assimetria facial e oclusal. A atividade anormal do músculo cervical e dos músculos mastigatórios pode ocasionar anormalidades morfológicas da mandíbula e da articulação temporomandibular (ATM) e contribuir para 0 desenvolvimento de desordens temporomandibulares. A restauração do equilíbrio bilateral das atividades do músculo cervical e a correção oclusal podem conduzir a uma melhora morfológica da coluna cervical e das ATMs e a correção da postura da cabeça.

Objetivando avaliar a assimetria morfológica e posicional da mandíbula de pacientes jovens com mordida cruzada posterior unilateral funcional, PINTO et al. ${ }^{128}$, em 2001, utilizaram uma amostra com nove jovens do gênero feminino e seis do gênero masculino, com idade média de 8,8 anos, avaliados no início do tratamento e aproximadamente 6 meses após a fase de contenção. Todos os pacientes apresentavam mordida cruzada posterior unilateral completa, envolvendo três ou mais dentes posteriores, um deslocamento funcional da relação cêntrica para a máxima intercuspidação habitual, e sem sinais ou sintomas de desordem temporomandibular. Utilizourse um aparelho de expansão palatina para expansão rápida da maxila, durante 1 mês e por mais 6 meses, como contenção. Utilizaram-se cortes tomográficos para avaliar o espaço articular, e radiografias submentonianas, para avaliar a assimetria morfológica aposicional. Os resultados demonstraram que a mandíbula apresentava-se significantemente maior no lado não cruzado do que no lado cruzado. A assimetria foi mais evidente no ramo mandibular e envolveu os processos coronóide e condilar. O espaço articular póstero-superior apresentou-se mais amplo no lado não cruzado do que no lado cruzado. Após o tratamento e a contenção, a mandíbula não demonstrou assimetria morfológica significante. Houve maior crescimento mandibular no lado cruzado, comparando-se com o lado oposto, além de um reposicionamento mandibular. Verificou-se uma rotação anterior do lado cruzado em direção ao lado não cruzado. Concluiu-se que a mordida cruzada posterior unilateral causa 
assimetrias morfológicas e posicionais da mandíbula em jovens, e que estas assimetrias podem ser amplamente corrigidas com a expansão precoce.

\section{4 - A Classe II, subdivisão}

Devido às relações oclusais assimétricas, as más oclusões de Classe II, subdivisão, geralmente apresentam dificuldades de tratamento. A natureza da assimetria oclusal pode ser devido às assimetrias dentoalveolares ou esqueléticas, ou a uma combinação destes fatores e acredita-se que esses fatores subjacentes complicam a obtenção de uma oclusão simétrica.

A relação de má oclusão de Classe II esquelética decorre de uma protrusão maxilar ou uma retrusão mandibular ou combinação de ambas estas características. Algumas vezes, porém, o complexo maxilomandibular pode estar bem relacionado e a Classe II resulta de uma má posição dos dentes em suas bases esqueléticas, estando os dentes superiores vestibularizados e os inferiores lingualizados em suas respectivas bases ósseas, ou uma combinação de ambos os arcos $105,115,174$. Enquanto que a Classe II, subdivisão pode ser conseqüente, primeiramente, da posição mais distal do molar inferior do lado da Classe $\|^{2,79,141}$, ou secundariamente, da posição mais mesial do molar superior deste mesmo lado79.

Em sua classificação das más oclusões, ANGLE5, em 1907, acreditava que a relação molar de Classe II se desenvolvia em virtude da erupção distal do primeiro molar inferior em relação à posição normal do primeiro molar superior e classificou as más oclusões de Classe II unilaterais em casos de subdivisão. Afirmou, mais especificamente, que a Classe II unilateral, ou subdivisão decorria da erupção distal do primeiro molar inferior relação ao primeiro molar superior do lado da Classe II.

Baseando-se em três casos de má oclusão de Classe II, subdivisão com etiologia e tratamento distintos, WERTZ174, em 1975, relatou a dificuldade em se diagnosticar e tratar pacientes com Classe II unilateral devido à sua origem multifatorial. Salientou a importância em verificar se a origem da assimetria é dentária ou esquelética. Além disso, comentou que tanto para a Classe II como para a Classe III, subdivisão, a sínfise encontra-se desviada para o menor lado da mandíbula em relação à linha média facial, havendo também desvio mandibular. Nos casos de discrepância severa do crescimento mandibular, 
necessitava-se de uma correção cirúrgica que dependia da quantidade de distorção facial presente. Nas assimetrias dentárias, os segmentos dos arcos dentários destes pacientes devem ser identificados individualmente para o estabelecimento do correto plano de tratamento.

Com o propósito de avaliar a assimetria mandibular, relacionando-a à dor e à palpação, WILLIAMSON; SIMMONS179, em 1979, utilizaram radiografias submentonianas e póstero-anteriores de 53 pacientes com má oclusão pré-tratamento ortodôntico, sendo 27 do gênero feminino e 26 do gênero masculino, com idade média de 14,2 anos, com a mandíbula posicionada em relação cêntrica. Para cada paciente, mediram-se as diferenças entre os lados direito e esquerdo da mandíbula, tanto na radiografia submentoniana, quanto na póstero-anterior. Observou-se o relacionamento dentário nos modelos, com intuito de verificar se havia uma má oclusão de Classe II mais acentuada no lado mais curto da mandíbula. A quantidade de dor pré-tratamento durante a palpação muscular foi correlacionada com o grau de assimetria encontrada. Não se demonstrou correlação estatisticamente significante entre a assimetria mandibular e a sensibilidade muscular. Constataram que a maioria dos casos da amostra apresentou assimetria, devendo os clínicos estar cientes da sua presença em todos os três planos do espaço quando se planeja o tratamento. Os resultados demonstraram que a má oclusão de Classe II de molar e de canino pode apresentar um lado com maior dificuldade de correção que o outro, caso não haja uma compensação da posição da fossa glenóide ou dos dentes superiores.

A assimetria mandibular foi definida por WILLIAMSON178, em 1981, como sendo a diferença entre o tamanho e a forma dos dois lados da mandíbula, podendo ocorrer no plano frontal, no horizontal (basilar), ou em ambos, e ser refletida no plano sagital. Como a posição do côndilo em relação cêntrica influencia a avaliação da desarmonia esquelética, deve-se sempre diagnosticar e finalizar os casos nesta posição. Utilizam-se as radiografias frontais e submentonianas, para se evidenciar alguma assimetria mandibular, realizando-as em relação cêntrica. Considerou que a assimetria sempre vem acompanhada de uma má oclusão como a Classe II, subdivisão ou uma Classe II bilateral, apresentando menor desenvolvimento mandibular do lado mais severo. Concluiu que ao se adotar o conceito de relação cêntrica para estes 
casos, planeja-se o arco superior, no lado deficiente, com ancoragem máxima.

Em 1988, ALAVI; BEGOLE; SCHNEIDER², com a finalidade de investigar a presença de diferenças significantes em relação às assimetrias faciais e dos arcos dentários, desenvolveram um estudo entre pacientes apresentando más oclusões de Classe II, subdivisão e com oclusão normal. A amostra consistiu em 28 jovens em cada grupo, com idade média de 17,1 anos, apresentando a dentição permanente até os primeiros molares. Utilizaram-se telerradiografias, radiografias póstero-anteriores e modelos de estudo para obtenção das medidas lineares, enquanto as medidas específicas foram agrupadas para produzir vários índices de assimetria. Verificaram que a assimetria ântero-posterior das más oclusões de Classe II, subdivisão devia-se, principalmente, à posição mais distal do molar inferior, do lado da Classe II. Entretanto, não foi possível determinar se a posição do molar inferior era devido a uma assimetria esquelética ou dentoalveolar. Verificaram, ainda, uma contribuição secundária da assimetria na região dentoalveolar da maxila.

Utilizando-se de radiografias submentonianas, ROSE et al.141, em 1994, compararam a simetria mandibular de 58 pacientes, sendo 28 com más oclusões de Classe II, subdivisão e 30 com más oclusões de Classe I. Este trabalho limitourse somente ao estudo da mandíbula, uma vez que as radiografias submentonianas não são específicas para a análise dos pontos maxilares. O primeiro molar inferior, quando avaliado em relação à base craniana ou à própria mandíbula, estava localizado mais posteriormente no lado da Classe II, nas más oclusões com subdivisão, em uma mandíbula que não exibia nenhuma assimetria. Qualquer diferença encontrada na assimetria mandibular não excluiu a possibilidade da presença de assimetria dentoalveolar ou esquelética no arco superior contribuir para as más oclusões com subdivisão. Concluíram que a Classe II, subdivisão era decorrente das assimetrias dentárias, visto que a mandíbula não exibe uma posição esquelética anormal nem mesmo assimetria esquelética.

Objetivando avaliar as assimetrias esqueléticas e dentárias em 30 pacientes com idade média de 11,6 anos, apresentando Classe II, divisão 1, subdivisão, MARTINS de ARAÚJO; SCHIRMER; ALMEIDA104, em 1994, utilizaram radiografias póstero-anteriores para verificar a presença de assimetria entre os lados de Classe I e de Classe II, divisão 1, subdivisão, além 
de modelos de estudo para se determinar a freqüência destas assimetrias. Demarcaram-se nove triângulos bilaterais nos traçados cefalométricos para descrever o complexo craniodentofacial. Calculou-se a área de cada triângulo, nas radiografias e a freqüência das assimetrias ântero-posterior e transversa, nos modelos. Os resultados não demonstraram diferenças estatisticamente significantes entre os lados de Classe I e II, nas radiografias, entretanto, a freqüência de assimetrias nos modelos foi estatisticamente significante em nível de $1 \%$, sendo que o arco inferior apresentou maior assimetria que 0 superior. Estas assimetrias foram mais evidentes no plano ântero-posterior do que no transverso e, nos arcos inferiores, do que nos superiores. Concluíram que, no plano frontal, as más oclusões de Classe II, divisão 1, subdivisão caracterizam-se por desvios dentários e não por displasias esqueléticas.

Propondo-se a quantificar e descrever as assimetrias dos arcos dentários na dentadura mista, KULA; ESMAILNEJAD; HASS90, em 1998, avaliaram 151 jovens, com faixa etária entre 7 a 11 anos, com sobressaliência acentuada, objetivando determinar se havia uma relação espacial entre os pontos dentários nos arcos entre si. O plano palatino mediano foi a referência para as medidas transversais, enquanto que um plano palatino mediano construído transversalmente no computador bi a referência para as medidas ântero-posteriores. Mais do que $30 \%$ dos jovens apresentaram assimetrias transversais maiores que $2 \mathrm{~mm}$ nos primeiros molares superiores permanentes. As mais altas médias de assimetrias transversal e ântero-posterior ocorreram nos primeiros molares superiores permanentes. Uma grande quantidade de jovens com sobressaliência acentuada apresentava assimetrias intra-arco significantes em muitos pontos bilaterais. Somente $3 \%$ destes jovens exibiam assimetrias intra-arco dos molares. A posição dos pontos em cada arco variou em relação às medidas nos arcos opostos. Embora grande número de pacientes apresentasse sobressaliência acentuada, muitos exibiram assimetrias intra-arcos significantes e poucos apresentaram assimetrias interarcos.

Objetivando investigar a presença de assimetrias dentárias e/ou esqueléticas entre 30 indivíduos com oclusão normal e 30 indivíduos com más oclusões de Classe II, subdivisão, JANSON79, também em 1998, avaliou tridimensionalmente as assimetrias dentoesqueléticas das más oclusões de 
Classe II, subdivisão por meio de radiografias submentonianas, pósteroanteriores e oblíquas corrigidas. A amostra constava de indivíduos de ambos os gêneros, com idade média de 15,76 anos, para o grupo de Classe II, subdivisão e 22,42 anos, para o grupo de oclusão normal, sendo que todos apresentavam os dentes permanentes até os primeiros molares. Os resultados demonstraram que a principal diferença entre a má oclusão de Classe II, subdivisão e a oclusão normal consistia numa posição mais distal do primeiro molar inferior do lado da Classe II, em uma mandíbula com assimetria subclínica e sem assimetria de posição. Uma diferença secundária entre os dois grupos consistiu na posição mais mesial do primeiro molar superior, no lado da Classe II. De acordo com estes resultados, a linha média dentária inferior também apresentou um desvio mais freqüente para o lado da Classe II, do que a linha média dentária superior, no sentido oposto, conforme evidenciado na avaliação bidimensional da radiografia frontal. Cefalometricamente, os arcos dentários nos casos de má oclusão de Classe II, subdivisão, apresentaram uma maior assimetria do que os de oclusão normal. Especulou que embora assimetrias esqueléticas não tenham sido identificadas na Classe II, subdivisão, elas poderiam se manifestar se os dois principais subgrupos dessa má oclusão (denominados posteriormente de Classe II, subdivisão - tipo 1 e tipo 2) fossem comparados individualmente com o grupo de oclusão normalp1.

\section{5 - Diagnóstico das más oclusões de Classe II, subdivisão}

Com o objetivo de identificar e quantificar a magnitude das assimetrias, muitos métodos têm sido utilizados, incluindo avaliações nas proporções verticais e horizontais da face pelo uso de fotografias faciais, análises radiográficas ou observações clínicas diretas.

O diagnóstico das assimetrias dentárias e esqueléticas pode ser realizado pela avaliação esquelética do paciente e pelo padrão do tecido mole facial, segundo BURSTONE30, 1998. As radiografias submentonianas e póstero-anterior são, particularmente, aplicáveis para o diagnóstico das assimetrias. A radiografia submentoniana auxilia mais precisamente no diagnóstico da assimetria, principalmente quando o problema é mandibular. $O$ tecido mole da face, a observação clínica precisa do aspecto frontal e inferior, 
juntamente com as fotografias faciais contribuem no diagnóstico para a detecção da existência de um problema esquelético.

Também em 1998, LEGAN92 afirmou que o diagnóstico das assimetrias dentofaciais, a história médica e os exames clínico, radiográfico e de modelos de estudo tornam-se necessários para se determinar a extensão do envolvimento do tecido mole, dos componentes esquelético e dentário, além do aspecto funcional. Comentou também que o exame clínico deve incluir uma análise intrabucal com a avaliação dos dentes e das linhas médias faciais, além da detecção de disfunção temporomandibular. O exame facial, pelas vistas frontal e lateral, deve ser conduzido para avaliar as assimetrias na morfologia facial e analisar a posição natural da cabeça. A palpação da maxila e do osso temporal, que suportam a fossa glenóide, podem estar em diferentes níveis em cada lado da cabeça. A avaliação do plano oclusal pode ser diretamente visualizada ao solicitar que o paciente morda uma espátula abaixadora de língua, posicionada horizontalmente, para se determinar seu relacionamento com o plano interpupilar. Ainda quanto ao aspecto frontal, considerou que a vista inferior da mandíbula ou a análise da radiografia submentoniana, auxilia na determinação da extensão da assimetria mandibular em relação ao resto da face. Concluiu que a hiperplasia condilar ou neoplasia podem ocasionar assimetrias esqueléticas verticais associadas às mordidas abertas unilaterais progressivas .

Alguns autores $30,79,138,159$ salientam a importância em se diagnosticar os casos de má oclusão de Classe II, subdivisão em relação cêntrica, para se verificar a real discrepância ântero-posterior que o paciente apresenta. A severidade da discrepância da linha média pode ser aumentada ou diminuída, dependendo de como a mandíbula se reposiciona ${ }^{138}$.

Dentre as várias metodologias e tecnologias disponíveis que possibilitam o diagnóstico prévio das assimetrias mandibulofaciais, destacamse a análise facial frontal, as radiografias póstero-anteriores e as radiografias submentonianas.

\subsection{1 - Análise facial frontal}

O simples exame visual direto pode ser mais preciso do que um bom método científico para o reconhecimento das assimetrias faciais, segundo 
SVED167, 1931. Em 1942, MOORE; HUGHES113, utilizaram a observação direta para analisar seus pacientes na cadeira odontológica. Embora CAMPBELL ${ }^{31}$, em 1950, tenha salientado que a visão não consistia num método acurado na avaliação da assimetria facial.

O primeiro a introduzir as fotografias no estudo das faces foi HERZBERG72, em 1952, afirmando que, provavelmente, a melhor maneira de desenvolver a habilidade na avaliação das faces consistia numa observação direta, criteriosa e repetida. Neste mesmo ano, GAVAN; WASHBURN; LEWIS 57 afirmaram que se os pontos anatômicos fossem marcados nas faces, muitas medidas poderiam ser calculadas precisamente por meio das fotografias dos pacientes.

$\mathrm{Na}$ avaliação frontal, o plano de Frankfurt, o plano sagital mediano ( $\mathrm{N}$ ENA) e o orbitário são demarcados na fotografia. Os lados direito e esquerdo são examinados para determinar assimetrias vertical ou lateral dos olhos, orelhas, processos zigomáticos, ângulos goníacos, pório, proeminência do mento e das partes dentofaciais relacionadas ${ }^{35}$. A análise facial consiste num método valioso na detecção das alterações das estruturas faciais. No exame frontal, pode-se verificar o deslocamento superior do ponto orbitário, a altura e o deslocamento lateral do processo zigomático, a altura do ramo mandibular, os deslocamentos do ângulo mandibular e lateral do mento (em oclusão e em repouso) e a altura dentária maxilomandibular. O exame frontal, inferior ou do perfil do paciente pode ser realizado diretamente ou com fotografias apropriadas. Estas avaliações faciais do tecido mole assemelham-se às avaliações esqueléticas realizadas nas radiografias ântero-posterior e submentoniana ${ }^{36}$.

Entre os muitos métodos propostos para a criação de um plano sagital médio, para avaliar a assimetria facial no plano frontal, estão o Násio-ENA ${ }^{36}$, o Subnasal-Próstio-Pogônio166 e o Násio-Subnasal51. O plano sagital médio consiste, basicamente, em uma linha aproximadamente reta, que passa pelos centros das estruturas anatômicas localizadas próximas ao meio da face ${ }^{166}$. Devido às críticas de $A D L E R^{1}$, em 1948, às técnicas de se criar uma linha média, porque "o próprio eixo de simetria é determinado baseando-se em um conjunto de estruturas que serão examinadas", SUTTON166, em 1968, propôs um método diferente para determinar o plano mediano. Em vez de estruturas 
anatômicas centrais, utilizam-se as extremidades laterais da face para estabelecer a linha mediana, uma vez que o centro da face é eqüidistante dessas extremidades. SUTTON 166 utilizou o zygion (o ponto mais lateral do arco zigomático) como a extremidade lateral da face, porque o crescimento na largura bizigomática do crânio é lento e segue uma velocidade constante. Construiu, então, a linha média nas radiografias cefalométricas ou diretamente na análise frontal dos pacientes, eqüidistante dos zygions. De acordo com SUTTON166, considera-se a face assimétrica no aspecto frontal, se uma ou mais estruturas bilaterais estiverem mais afastadas do plano sagital médio do que a estrutura correspondente do outro lado, ou se o centro de estruturas não pareadas (ex.: o nariz) não se situa nessa linha de referência.

Em estudo sobre o diagnóstico e plano de tratamento das más oclusões de Classe II unilaterais, WERTZ174, em 1975, enfatizou a necessidade de avaliar a relação das linhas médias maxilomandibulares com a linha média facial, quando examinando o paciente visual e manualmente. Relatou que as fotografias da face consistem num ótimo recurso auxiliar na determinação de assimetrias.

Um método visual de análise do desvio das linhas médias dentárias superior e inferior proposto por JERROLD; LOWENSTEIN83, em 1990, consiste em traçar-se uma linha imaginária, perpendicular ao solo, passando pelo centro da glabela. Essa avaliação frontal é feita com o paciente sorrindo, em oclusão habitual. Em uma face simétrica, essa linha deve ser uma bissetriz do nariz e do filtro, coincidindo com as linhas médias da maxila e mandíbula, caindo diretamente sobre o mento mole.

A fotografia torna-se cada vez mais uma ferramenta importante na odontologia. Mas a documentação do tratamento ortodôntico ou ortopédico, com fotografias pré e pós-tratamento, pode tornar-se enganosa, caso as características de uma dessas fotografias estejam distorcidas. O ortodontista deve estar constantemente informado da importância da padronização fotográfica, quando se deseja documentar as mudanças obtidas com o tratamento. CLAMAN; PATTON; RASHID ${ }^{37}$, também em 1990, apresentaram considerações importantes para fotografias faciais frontais e de perfil. A seleção das lentes, posição da câmera, posição e distância do paciente devem ser compreendidas e controladas quando se deseja uma reprodução precisa. 
Quando não se reproduz a posição estável da cabeça, provavelmente há uma distorção da aparência. Nas fotografias de perfil, uma inclinação da cabeça para frente ou para trás, induz a um padrão prognata ou retrognata. Nas fotografias frontais, uma rotação da cabeça altera a percepção da simetria facial. Utilizando pontos faciais facilmente reconhecidos, pode-se padronizar as fotografias frontais e laterais para comparações mais coerentes.

Em um estudo realizado por FERRARIO et al. ${ }^{50}$, em 1993, obtiveram fotografias frontais e laterais de 108 adultos jovens saudáveis (57 do gênero masculino e 51 do gênero feminino) em duas posições, tanto em pé, quanto sentados e utilizaram um protocolo padronizado, para descrever quantitativamente a estrutura do tecido mole craniofacial, a relação entre as estruturas faciais e a postura da cabeça em relação ao solo. Esta análise fotográfica confirmou que o terço inferior da face (região maxilomandibular) apresenta um maior grau de assimetria que outras regiões faciais e que o tecido mole apenas mascara parcialmente a assimetria esquelética. Os jovens assimétricos compensaram sua aparência modificando a postura da cabeça em relação ao solo, para que no plano frontal, o eixo interpupilar e o plano oclusal estivessem paralelos ao solo. Quando fotografados em pé, o plano de Frankfurt direcionava-se para cima e para frente, com um ângulo médio de $13^{\circ}$ em relação ao solo. Quando fotografados sentados este ângulo estava mais próximo do horizontal ( $5^{\circ}$ no gênero masculino e $8^{\circ}$ no gênero feminino). Este resultado confirma a necessidade de uma reavaliação cuidadosa dos protocolos padronizados cefalométricos e fotográficos com relação ao posicionamento em pé ou sentado dos pacientes.

Em 1998, LEGAN92 argumenta que embora o exame clínico seja o método mais importante na avaliação das assimetrias, necessita ser complementado pelas fotografias e pelo estudo dos modelos, apresentando o registro de mordida obtido pelo arco extrabucal de transferência para se localizar as estruturas envolvidas na assimetria. As fotografias faciais e intrabucais constituem-se instrumentos indispensáveis para a documentação das condições iniciais, bem como para o estabelecimento da lista de problemas e do planejamento, sendo essenciais também na avaliação dos resultados do tratamento. 
O exame clínico de um paciente, quando executado de maneira adequada e meticulosa consiste um ato de fundamental importância dentro de um diagnóstico. De acordo com ALMEIDA4, em 1999, deve-se realizar o exame clínico de maneira objetiva, por meio das observações feitas pelo profissional de saúde; executado numa seqüência lógica e constante de procedimentos, realizados diretamente no paciente, com a finalidade de coletar os dados, que serão somados aos de outros exames. Na Ortodontia, especificamente, objetiva-se com o exame clínico: documentar as características gerais e odontológicas do paciente; avaliar suas estruturas faciais, oclusais e funcionais; e determinar quais exames auxiliares serão necessários para o diagnóstico final. Este exame se divide basicamente em duas fases: extrabucal, que, por sua vez se subdivide em cinco etapas (exame frontal da face, exame lateral da face, exame da respiração, exame dos lábios e exame da deglutição); e intrabucal, onde se examinam aspectos clínicos da cavidade bucal do paciente (higienização; dentes restaurados; índice cariogênico; estruturas periodontais, mucosas, amídalas e língua; e as características ortodônticas). Por meio do exame clínico frontal da face, podese observar a presença de alguma assimetria mais acentuada, detectar a existência de determinada má oclusão ou distúrbio no desenvolvimento normal da face, averiguando uma série de outras ocorrências que possam estar acometendo o paciente.

EDLER; WERTHEIM; GREENHILL45, em 2001, investigaram a concordância da avaliação clínica e computadorizada da assimetria mandibular. Doze fotografias padronizadas foram analisadas por 8 clínicos experientes gerando uma escala, da normalidade até assimetria mandibular acentuada. Desenhou-se o contorno da mandíbula no computador e traçaramse duas linhas: linha $A$ (da inserção inferior de uma orelha à outra - Otobasion inferius) e linha $B$ (na bissecção da linha $A$, perpendicular à mesma). Utilizaram-se quatro métodos para quantificar a assimetria, baseados nas diferenças direita/esquerda no perímetro, área, compactação e proporção do centro da área. Houve boa concordância na probabilidade de necessidade de tratamento, porém apenas concordância moderada quanto a um nível "aceitável" de assimetria. As diferenças nas proporções dos perímetros não se correlacionaram adequadamente com a avaliação clínica, entretanto, as 
análises de área e compactação demonstraram concordância absoluta. Já nas proporções das diferenças no centro da área, houve $75 \%$ de sensibilidade e $85 \%$ de especificidade na análise digital. Concluiu-se, portanto, que a avaliação computadorizada pode ser útil na definição dos contornos mandibulares e quantificação de assimetrias causadas pelo crescimento, tratamento e por recidivas.

Portanto, uma vez realizada a análise do tecido mole, clínica ou fotograficamente, pode-se avaliar a extensão do envolvimento do tecido esquelético subjacente por meio de várias técnicas radiográficas. Nos casos com assimetrias clínicas, uma avaliação radiográfica pode revelar uma base esquelética, assimétrica em maior ou menor grau79.

\subsection{2 - Radiografia Póstero-Anterior (PA)}

Dentre os métodos para a avaliação da assimetria craniofacial, o mais utilizado é o exame em norma frontal, pois compara o grau e a localização do problema esquelético, possibilitando, também a aferição das discrepâncias transversais. No entanto, sua maior desvantagem encontra-se na localização dos pontos relacionados. Assim, alguns autores 88,145 descreveram pontos facilmente identificáveis pela radiografia póstero-anterior, que foram: os contornos lateral e superior da órbita, a Crista galli, o ponto gônio, a base craniana anterior e a asa menor do osso esfenóide.

Segundo JACKSON78, em 1937, a determinação do plano sagital mediano do crânio, em estudos com a radiografia PA, é complexa e nem sempre possível. Por esta razão, alguns trabalhos propuseram diferentes metodologias, para aperfeiçoar este método de avaliação.

Os estudos de HARVOLD66, em 1951, para análise da simetria do esqueleto facial foram um dos primeiros relatos do uso de radiografias cefalométricas póstero-anteriores. Desenvolveu-se o método da linha-X para estabelecer o plano sagital mediano. Esta linha foi construída por meio de uma perpendicular à linha horizontal que conecta as suturas frontozigomáticas direita e esquerda, passando pelo ápice da Crista galli e foi utilizada para avaliar a simetria do crânio. Sua amostra consistia de 80 crânios secos, com idades variando dos três aos vinte anos. Determinou que freqüentemente a espinha nasal anterior estava muito próxima à linha-X $(<1,5 \mathrm{~mm})$ em mais de 
$90 \%$ das radiografias. Além disso, as distâncias foram medidas da linha-X aos lados das bordas temporais do osso zigomático e da sutura zigomaticomaxilar, no processo zigomático. $O$ índice de simetria determinado por estas análises nas radiografias PA foi muito próximo dos resultados antropológicos realizados diretamente em crânios secos. Concluiu que era possível identificar com o auxílio da radiografia frontal, assimetrias do esqueleto facial com um considerável grau de precisão.

SHORE ${ }^{156}$, em 1959, realizou um estudo em radiografias pósteroanteriores, em que calculou vários graus de assimetria facial em humanos com oclusão normal e má oclusão. Propôs um método utilizando pontos facilmente discerníveis para construir dois pontos faciais médios e produzir uma linha de referência média facial nesta radiografia. $O$ ponto 1 foi definido como ponto médio entre os aspectos mediais das órbitas, no nível do plano esfenóide e o ponto 2 foi determinado pelas estruturas anatômicas do nariz, projetando-se linhas tangentes às bordas laterais da parede nasal e perpendiculares ao eixo do cefalostato. Interceptaram as duas projeções por uma linha tangente ao ponto mais inferior de cada uma das cavidades nasais e dividiu-se ao meio a distância entre as intersecções para formar o ponto 2.

As aplicações das radiografias PA consistem na avaliação de desvios de linha média, inclinação do plano oclusal, assimetria facial, desvios funcionais da mandíbula, tipologia mandibular, avaliações dentárias e análises de deformidades faciais. Em 1965, MULICK ${ }^{116}$ descreveu uma técnica para a obtenção de radiografias PA para utilização no diagnóstico ortodôntico. Durante o traçado anatômico para orientação no sentido horizontal, recomendou a utilização do eixo transporiônico, do eixo que passa pelos forames redondos ou do eixo das suturas frontozigomáticas direita e esquerda. Já no sentido vertical, a linha de referência pode ser construída de duas maneiras: 1-) como uma perpendicular a qualquer um dos 3 eixos horizontais, passando pelo maior número de estruturas centrais e 2-) como uma linha vertical absoluta, passando pelo maior número de estruturas anatômicas centrais. As estruturas anatômicas centrais referem-se à Crista galli, sutura palatina mediana e vômer.

A determinação das posições dos centros dos meatos utilizando-se as olivas metálicas apresenta precisão duvidosa, pois pode haver diferenças na espessura nos dois meatos e na compressibilidade dos tecidos moles sobre os 
mesmos 55 . Em 1968, SUTTON166 contestou a utilização dos meatos para estabelecer pontos fixos para se determinar o eixo transverso do crânio devido à sua estrutura. Isto ocorre em função do desnível vertical e da possível posição mais à frente de um meato em relação ao outro. Também, há possibilidade de o paciente apresentar ligeira rotação ou inclinação da cabeça, pois as extremidades das olivas podem não preencher os meatos.

Utilizando a radiografia PA, VIG; HEWITT172, em 1975, avaliaram a assimetria facial por meio de triângulos bilaterais que objetivava determinar diversos pontos localizados nas radiografias e uma linha média determinada para a maxila e a mandíbula, separadamente. Delineourse o eixo X (linha média do terço médio da face) a partir de uma linha traçada do mentoniano, pelas bissetrizes das linhas que unem os pontos bilaterais condilares e goníacos. Considera-se o ângulo de divergência entre essas duas linhas como sendo o grau de assimetria entre a maxila e a mandíbula. A bissetriz destes dois eixos pode ser arbitrariamente definida como o eixo facial. Para a avaliação da assimetria das várias partes componentes da face, construíramse sete triângulos bilaterais, com a área de cada um calculada para determinar a assimetria relativa de cada parte componente da face.

Em 1983, GRAYSON; MCCARTHY; BOOKSTEIN63 propuseram uma análise cefalométrica tridimensional com multiplanos objetivando a visualização das linhas médias esqueléticas em níveis progressivos de profundidade do complexo craniofacial por meio de quatro traçados das radiografias PA. Esta técnica demonstrou um conceito tridimensional das deformidades do esqueleto craniofacial, proporcionando informações de diagnóstico muito úteis ao clínico, permitindo que a severidade da assimetria fosse avaliada de posterior para anterior e vice-versa. A aplicação de uma fórmula matemática a um sistema biológico, como no cálculo das áreas dos triângulos direito e esquerdo na radiografia, não deve ser realizada, sendo mais válido observar as diferenças, em forma e posição, desses triângulos construídos bilateralmente. Estes dados auxiliam também na formulação do prognóstico, assim como na determinação da área onde a cirurgia pode ser realizada, caso seja necessária.

GRUMMONS; VAN DE COPELLO64, em 1987, apresentaram uma análise de assimetria frontal bastante detalhada, que consistia na construção de quatro linhas horizontais de referência para mostrar o grau de paralelismo 
das estruturas faciais. A linha de referência média sagital (LRM) foi traçada a partir da Crista galli, tangenciando a espinha nasal anterior (ENA) até a região mentoniana, perpendicular ao plano horizontal (plano Z) que conecta as suturas frontozigomáticas. Selecionou-se a LRM como linha de referência, pois se aproxima do plano visual formado pelo subnasal e os pontos médios entre os olhos e sobrancelhas. A morfologia mandibular foi avaliada por meio de triângulos bilaterais a partir do côndilo, das chanfraduras antegonianas e do mentoniano e a comparação da assimetria maxilomandibular foi avaliada por meio de pares de triângulos. Concluíram que esta análise fornece um método prático e funcional de determinação da localização e quantidade de assimetria facial, apresentando grande valor clínico quando complementada com informações de radiografias em norma lateral e submentoniana.

Comentando sobre um outro método de mensuração das assimetrias por meio de radiografias frontais, FERGUSON49, em 1993, desenvolveu uma técnica que se baseava na utilização de uma linha de referência horizontal determinada nas margens superiores orbitárias e uma linha de referência vertical, no plano sagital mediano, construída em ângulo reto à linha supraorbitária, passando pela Crista galli. Pela medição dos ângulos entre o plano sagital mediano e uma linha da Crista galli à ENA e outra linha da Crista galli ao mentoniano, determinourse a assimetria esquelética neste estudo.

Em 1994, SKOLNICK et al. ${ }^{163}$ obtiveram radiografias póstero-anteriores também com o plano de Frankfurt paralelo ao plano horizontal e a mandíbula na posição do primeiro contato oclusal. Avaliou-se a assimetria mandibular em relação ao plano médio sagital, construído por uma linha vertical conectando o centro da Crista galli e o centro da espinha nasal anterior, estendendo-se até a mandíbula.

Uma outra utilização das radiografias frontais descrita por SHROFF159, em 1998, além de permitir o diagnóstico das más oclusões assimétricas, consiste na avaliação da mordida cruzada posterior, auxiliando também na diferenciação da mordida cruzada esquelética, decorrente da atresia do palato, da mordida cruzada dentária devido à inclinação axial anormal do molar. Para a visualização da inclinação axial dos molares no plano frontal, uma linha horizontal pode ser desenhada ao longo das cúspides, conectando os molares 
direito e esquerdo do arco, comparando-se, posteriormente as inclinações axiais dos dois molares.

Também em 1998, LEGAN92 afirmou que quando se deseja comparar estruturas direita e esquerda da face, a radiografia cefalométrica pósteroanterior constitui-se num recurso valioso, pois se encontra em uma distância relativamente semelhante do filme e da fonte radiográfica. Podem ser obtidas em oclusão cêntrica, bem como em posição de repouso. Com a utilização de dois filmes radiográficos, pode-se determinar a extensão de um possível desvio funcional.

Na prática clínica, o uso da radiografia PA, entretanto, pode ainda ser limitado, já que é difícil reproduzir a posição da cabeça em radiografias subseqüentes, assim como os pontos são difíceis de serem localizados devido à superposição das estruturas. Por isso, outras técnicas radiográficas são também utilizadas para avaliar a assimetria facial, como as radiografias oblíquas e submentonianas 64 .

\subsection{3 - Radiografia submentoniana}

Comparando-se com a radiografia póstero-anterior, a radiografia submentoniana apresenta-se com maior potencial para a avaliação das assimetrias por permitir que pontos anatômicos na base do crânio, que se encontram distantes dos ossos da face, sejam utilizados para a determinação do eixo sagital mediano ${ }^{54}$.

Quem primeiro descreveu a radiografia submentoniana foi SCHUELLER ${ }^{151}$, em 1905 e mais tarde, MERRILL109, em 1949.

Objetivando investigar sobre a precisão da radiografia submentoniana, GILBERT60, em 1960, utilizou um filme radiográfico paralelo ao plano horizontal de Frankfurt e perpendicular ao solo. Utilizou um aparelho de Rx que produzia $140 \mathrm{kVp}$, para a obtenção de uma imagem nítida, sendo que o feixe de raios $X$ incidia no vértice do crânio. Apresentou grande precisão para as mensurações de largura, entretanto, erros significantes foram encontrados nas medidas de comprimento das estruturas. Considerourse este método bastante útil na avaliação das assimetrias esqueléticas e nas deformações associadas às fissuras labiopalatais, apesar de nenhuma análise cefalométrica ter sido proposta. 
Com intuito de avaliar a assimetria e auxiliar no diagnóstico das más oclusões, BERGER ${ }^{15}$, em 1961, foi o primeiro a sugerir a utilização da radiografia submentoniana na cefalometria. Para a obtenção desta projeção, determinou que a cabeça do paciente deveria estar posicionada num cefalostato, com o plano de Frankfurt, perpendicular ao solo. A distância entre o tubo e o filme deveria ser de $1,50 \mathrm{~m}$. Para a orientação da avaliação das estruturas anatômicas, demarcou e traçou diversos pontos, linhas e planos. Localizourse o ponto buccale na região anterior da superfície interna do arco zigomático e o ponto angulare, na ponta de uma densa área radiopaca de forma triangular, formada pela união das bordas superior e inferior da órbita com o arco zigomático. Comentou que a conexão dos pontos buccale determina o plano buccale que passa pelos primeiros molares superiores, enquanto que a conexão dos pontos angulare determina o plano angulare que corta 0 arco dentário entre os caninos e pré-molares. O plano condilar passa pelos contornos mais distais de cada côndilo. Para a determinação de uma linha média sagital, BERGER ${ }^{15}$ utilizou, como orientação, os seguintes pontos: Crista galli, crista frontalis, vômer, tubérculo do atlas, processo odontóide e crista occipital interna. Não foi possível traçar uma linha reta unindo todos esses pontos, tornando-se necessária alguma interpolação, pois a simetria do crânio consiste numa situação muito rara. Para completar o sistema de coordenadas, utilizou-se uma linha, perpendicular à linha sagital mediana, cortando-a ao meio. Estas linhas e os planos de orientação permitiam uma melhor visualização das assimetrias dentoesqueléticas das más oclusões. Entretanto, o autor não testou a reprodutibilidade e validade dessa linha de referência.

Para determinar a linha média da radiografia submentoniana, BERGER $^{16}$, em 1964, demonstrou um método desenhando-se uma linha passando pelo vômer, pela parte posterior do septo nasal e pela Crista galli. Sugeriu que a linha média basilar uma vez construída poderia ser utilizada no estudo da assimetria facial. Afirmou que a radiografia submentoniana poderia ser utilizada simultaneamente com as projeções lateral e frontal para a análise das deformidades dentofaciais.

Ainda neste ano, NAHOUM; FIASCONARO; DI SALVO117 asseguraram que a radiografia basilar relaciona os dentes, bem como a maxila e a 
mandíbula com o esqueleto craniofacial. Dessa forma, afirmaram que a radiografia submentoniana poderia ser incorporada na análise tridimensional das deformidades cranianas, especialmente quando as assimetrias não são detectadas em projeções laterais comuns.

MOSS; SALENTIJN114, em 1971, verificaram em seu trabalho que a passagem e a localização dos feixes neuromusculares não podem ser violados durante o crescimento. Tal afirmação baseia-se nos estudos da estabilidade e homogeneidade da localização do forame mentoniano que serviram de referência para o forame oval como pontos de construção para o eixo de referência sagital mediano. Em avaliações radiográficas de uma série relativamente grande de crânios em idades dentárias variadas, com implantes colocados no forame oval, mandibular e mentoniano, revelaram que suas posições foram estáveis durante o crescimento. Preconizaram que a radiografia submentoniana deve ser tomada com a cabeça posicionada de tal forma que o plano de Frankfurt esteja paralelo ao plano do filme e o plano sagital mediano pode ser derivado dos forames na base craniana.

Utilizando-se os forames espinhosos, pela vista basilar, como pontos de referência, MARMARY; ZILBERMAN; MIRSKY103, em 1979, avaliaram a confiabilidade na construção de uma linha de referência média, para o estudo da assimetria. Utilizaram radiografias submentonianas de 86 crânios secos, obtendo-se uma linha média em cada traçado, da seguinte forma: os centros dos forames espinhosos foram unidos e uma linha perpendicular foi traçada para servir como linha média, mensurando-se várias estruturas pareadas e não pareadas até essa linha média. Os desvios médios de cada ponto estavam dentro dos limites do erro de medição. A reprodutibilidade dessa técnica foi conferida por meio de um segundo traçado de oito radiografias selecionadas aleatoriamente. Concluíram que esta linha média vertical, construída perpendicularmente à linha horizontal formada pelos forames espinhosos, realmente assemelha-se ao plano sagital mediano, apresentando grande confiabilidade na avaliação do grau de assimetria presente em radiografias submentonianas.

Em 1985, GRAYSON et al.62 objetivaram aplicar o método de traçado cefalométrico multiplanos 63 , utilizando a radiografia submentoniana e discutindo sua participação no diagnóstico e plano do tratamento ortodôntico. 
Nesta análise, o cefalograma foi traçado três vezes, definindo-se os pontos e as estruturas de três planos basilares e apresentando as instruções para o seu traçado. Afirmaram que este método auxilia no restabelecimento do relacionamento tridimensional que existe nos filmes radiográficos com duas dimensões. Descreveram também um método para orientar a construção da linha média ântero-posterior de estruturas da base craniana. Esta linha média construída foi transportada para cada plano, sendo crítica para relacionar a localização e extensão da deformidade craniana na análise tridimensional. Como nas telerradiografias, os traçados pré-cirúrgicos nas radiografias basilares podem ser manipulados para simular as alterações esqueléticas previstas na cirurgia.

Em virtude da facilidade de se identificar estruturas de referência médiosagitais confiáveis, difíceis de se localizar na PA, tem-se utilizado bastante a radiografia submentoniana na avaliação da assimetria craniofacial8. ARNOLD; ANDERSON; LILYEMARK8, em 1994, utilizaram a radiografia submentoniana para avaliar 44 adultos, com a análise de assimetria desenvolvida por RITUCCI; BURSTONE140, em 1981, e publicada por FORSBERG; BURSTONE; KANLEY54, em 1984. Esta análise de assimetria consiste na utilização de pontos anatômicos bilaterais, criando sistemas de coordenadas de referência que podem ser utilizados para avaliar outros pontos. Três componentes foram analisados: a base do crânio, 0 complexo zigomaticomaxilar e a mandíbula e cada componente apresentava estruturas que eram analisadas quanto à assimetria, em relação ao sistema de referência do forame espinhoso, assim como em relação ao sistema de referência na linha média, originário daquele componente. Analisaram-se também os côndilos em relação ao eixo intercondilar (um eixo médio de referência derivado da própria mandíbula) para determinar sua posição simétrica em relação à mandíbula. Esse sistema de análise permite estabelecer se a mandíbula está assimetricamente posicionada em relação à base craniana, ou se a estrutura mandibular apresenta uma forma assimétrica. Portanto, a base craniana apresentou medidas de assimetria realizadas em relação ao sistema de coordenadas de referência mediosagital, derivado dos forames espinhosos bilaterais. O complexo zigomaticomaxilar utilizou a linha transpterigomaxilar e sua bissetriz perpendicular como linha de referência mediosagital para medir a 
assimetria na região facial média8,54. Finalmente, a mandíbula apresentava um sistema de referência de coordenadas baseado na linha transcondilar e sua bissetriz perpendicular, para medir a assimetria dentro da mandíbula8,54. Avaliaram-se diversas estruturas pareadas e não pareadas por comparação com esse sistema de coordenadas. Mensuraram a distância até as linhas médias, para as estruturas bilaterais, enquanto as diferenças foram calculadas e, para as estruturas não pareadas, mediram a distância até o plano sagital médio.

\section{6 - Tipos de tratamento da Classe II, subdivisão}

Existem várias formas de se tratar a Classe II, subdivisão. Pode-se empregar diferentes modalidades de tratamento, dependendo das características associadas à má oclusão, como: a severidade da discrepância ântero-posterior, sua etiologia, ou seja, se é dentária ou esquelética, a idade 169 e a colaboração do paciente $29,30,79,80,108,170,181$. O plano de tratamento, a correção e a contenção da Classe II, subdivisão apresentam dificuldades, necessitando de uma proposta de planejamento e diagnóstico adequados, condição essencial para qualquer sucesso clínico ${ }^{174}$.

Utiliza-se a terapêutica assimétrica conservadora para o tratamento de pequenas assimetrias de origem dentária, ou seja, os aparelhos extrabucais assimétricos ${ }^{181}$, os dispositivos ortopédicos funcionais $52,85,107,108,112,136,144,159$ e os aparelhos fixos associados aos elásticos de Classe ||29,82,159 ou aos dispositivos intrabucais distalizadores $21,39,58,159$ sem envolver extrações. Nos casos de assimetrias dentárias severas, realizam-se as extrações assimétricas para se conseguir espaço necessário para que uma mecânica assimétrica possa ser conduzida, ou mesmo, para compensar algumas assimetrias esqueléticas $30,82,170$.

Realizando-se extrações assimétricas, deve-se associar a ancoragem intra e extrabucal para que se maximize a possibilidade de se realizar o tratamento com uma mecânica assimétrica, obtendo-se, como resultado final, uma relação simétrica dos dentes anteriores. Nos casos extremos de assimetria oclusal associada à assimetria facial, o tratamento mais adequado envolve uma combinação de ortodontia e cirurgia ortognática98. 


\subsection{1 - Tratamento ortopédico funcional da Classe II, subdivisão}

Utilizam-se os aparelhos funcionais em pacientes na fase ativa de crescimento, visando corrigir as discrepâncias ântero-posteriores, verticais e transversais pela restrição e/ou redirecionamento do crescimento das bases apicais. O sucesso do tratamento do crescimento facial assimétrico parece depender da severidade da anomalia. Entretanto, a avaliação pré-tratamento das condições do perfil facial tegumentar e das bases apicais e suas mudanças durante o crescimento mostraram que a hipofunção muscular pode ser significantemente compensada durante a terapia ortopédica. Porém, o tratamento somente com aparelhos funcionais nem sempre é eficaz, necessitando da terapia ortodôntica corretiva geralmente após a terapia funcional41,70.

Avaliando pacientes pubescentes que sofreram uma fratura condilar PROFFIT; VIG; TURVEY136, em 1980, preconizaram que tais pacientes devem ser submetidos, inicialmente, ao tratamento ortopédico para estimular o crescimento condilar e o desenvolvimento dos tecidos envolvidos. Com intuito de estimular o crescimento do lado afetado, pode-se recorrer ainda aos aparelhos funcionais híbridos que amenizam as deformidades faciais.

Estudando pacientes com côndilos anormais MELSEN; BJERREGAARD; BUNDGAARD 108, em 1986, demonstraram os efeitos do tratamento com aparelhos funcionais. Concluíram que a microssomia hemifacial não tratada causa a assimetria facial, progredindo durante 0 desenvolvimento pós-natal. A correta interação entre o músculo e o osso constitui-se na condição necessária para que ocorra a aposição óssea e conseqüente produção da simetria facial. Relataram o tratamento de três pacientes com côndilos anormais tratados com o ativador, tendo seus resultados analisados radiográfica e clinicamente. Verificaram que 0 desenvolvimento de um equilíbrio muscular torna-se possível mesmo em pacientes com microssomia hemifacial, apresentando hipofunção muscular. Concluíram que quando se inicia precocemente o tratamento há a obtenção da aposição óssea para o estabelecimento de simetria, pois o resultado depende da colaboração do paciente e do período correto de intervenção.

Um caso clínico tratado com fechamento assimétrico do espaço da agenesia no segmento póstero-inferior foi descrito por FIORENTINO; 
MELSEN52, em 1996. A paciente com 11 anos de idade apresentava uma Classe II esquelética, com uma sobressaliência de $7 \mathrm{~mm}$, uma sobremordida de 5,5mm e desvio da linha média superior para o lado direito em relação à linha média facial. Na radiografia panorâmica, detectourse uma agenesia do segundo pré-molar inferior esquerdo. Determinaram um avanço mandibular de 2,5mm com o aparelho de Herbst que serviu como ancoragem intrabucal, monitorando a linha média, durante o fechamento do espaço do lado esquerdo. Concluíram que o tratamento com 0 aparelho de Herbst possibilitou 0 fechamento do espaço assimétrico, sem provocar efeitos indesejáveis, em termos de assimetria, no arco dentário superior. Os diferentes níveis de força gerados pelo aparelho de Herbst nos dois lados não produziram um padrão de crescimento assimétrico na maxila, mas foi suficiente para evitar o desenvolvimento de uma assimetria do arco inferior.

Com o intuito de analisar clinicamente e por meio de tomografias computadorizadas os efeitos da intervenção ortopédica precoce em pacientes com microssomia hemifacial, KAHL-NIEKE; FISCHBACH85, em 1998, avaliaram as mudanças no tecido mole e duro da articulação temporomandibular pré e pós-tratamento ortopédico de cinco pacientes debilitados na região condilar. Concluíram que houve uma estabilidade e diminuição da diferença condilar esquerda e direita, além de uma melhora do volume muscular. Entretanto, não se pode dar um prognóstico a longo prazo nos casos de deficiências musculares extremas após a cessação do crescimento. A maioria dos casos desta pesquisa obteve também uma melhora na simetria facial, função mandibular, estética facial e oclusão dentária.

\subsection{2 - Tratamento ortodôntico corretivo da Classe II, subdivisão}

A literatura relata a existência de dois tipos distintos de Classe II, subdivisão79. Cada tipo requer um planejamento de tratamento específico, de acordo com suas características. Em grande parte dos casos de Classe II, subdivisão, a linha média dentária superior se apresentará coincidente, ou com um mínimo desvio, com o plano sagital mediano e a linha média dentária inferior se apresentará deslocada para o lado da Classe II, em relação ao plano sagital mediano (devido ao posicionamento mais para posterior do molar deste lado), em uma face apresentando uma assimetria subclínica ${ }^{38}$. Neste caso, 
uma das melhores opções de tratamento consistirá da extração de dois prémolares superiores e de um pré-molar inferior do lado da Classe 2,29,35,36,82,174, desde que o perfil do paciente permita certa retração dos incisivos superiores e inferiores. Isto produzirá uma oclusão final com o lado da Classe I terminando em Classe I de molar e de canino, enquanto que no lado da Classe II, o molar terminará em Classe II e o canino em Classe I, com as linhas médias dentárias superiores e inferiores coincidentes entre si e com o plano sagital mediano.

As mesmas características poderão estar presentes em pacientes com assimetria subclínica ${ }^{38}$, cujo perfil não permita esse esquema de extrações e com uma certa quantidade de retração conseqüente. Assim, o tratamento basicamente consistirá em se obter a correção ântero-posterior do lado da Classe II, com a utilização de elásticos de Classe II unilaterais, ou com o sistema de GIANELLY; PAUL ${ }^{59}$, utilizando-se elásticos de Classe II e elásticos diagonais anteriores. Em todo caso, tudo dependerá enormemente da colaboração do paciente. Esse tipo de mecânica unilateral é muito difícil de ser realizada e pode afetar o arco superior concomitantemente ${ }^{141}$, além de causar também inclinações indesejáveis do plano oclusal29.

Uma outra combinação de má oclusão de Classe II, subdivisão, que ocorre com menor freqüência, consiste naquela em que há desvio da linha média dentária superior em relação ao plano sagital mediano (devido à posição mais para anterior do molar, do lado da Classe II) e coincidência da linha média dentária inferior, em relação a esse plano, em caso sem apinhamento superior ou inferior. Nesse caso, os melhores resultados seriam proporcionados pela extração de apenas um pré-molar superior do lado da Classe II, terminando com uma relação molar de Classe II desse lado, mas com as linhas médias dentárias coincidentes entre si e com o plano sagital mediano. Casos de pacientes em crescimento e que sejam colaboradores, em que o desvio ânteroposterior não seja tão acentuado, podem admitir a correção com a utilização de forças extrabucais assimétricas ${ }^{79}$.

A assimetria ocorre mais freqüentemente que a simetria, segundo BURSTONE29, em 1979, sendo seu diagnóstico de suma importância no planejamento. Afirmou que a maioria das discrepâncias de linha média é causada pela assimetria esquelética e muitas vezes este fator passa 
despercebido no plano de tratamento, provocando dificuldades na finalização dos casos. Objetivando a correção da linha média, deve-se analisar tais assimetrias em quadrantes para que se planeje uma mecânica assimétrica detalhada. Deve-se evitar a utilização de elásticos de Classe II de um lado, de Classe III do outro e elástico cruzado anterior, pois provocam inclinações indesejáveis do plano oclusal esteticamente desfavoráveis. Nas assimetrias esqueléticas, as linhas médias da maxila e da mandíbula não coincidem, constituindo uma discrepância de linha média das bases apicais. As extrações assimétricas, com movimentações de corpo de um lado e inclinações do outro, constituem-se recursos empregados na mecânica assimétrica com variação da perda de ancoragem em cada lado. Deve-se minimizar o uso de elásticos unilaterais, uma vez que provocam efeitos colaterais no plano oclusal. Pode-se utilizar os oclusogramas no diagnóstico inicial dos casos, possibilitando um correto planejamento da mecânica e solucionando o problema de forma adequada .

A maioria dos casos de assimetria dentária apresenta uma história associada de perda precoce de molar decíduo com conseqüente migração mesial dos molares adjacentes. Em 1995, BERGAMINI; MELSEN14 comentaram que quando se perde um dente, o seu adjacente migra em direção ao espaço presente, e quando a perda ocorre unilateralmente, resulta numa assimetria dentária. Somente uma oclusão muito estável pode prevenir estas migrações secundárias. Descreveram um caso clínico em que se realizou uma biomecânica com sistema assimétrico de força para a correção da linha média. A paciente de 24 anos apresentava uma relação de Classe II, subdivisão direita, uma sobressaliência de $11 \mathrm{~mm}$, uma sobremordida de $5 \mathrm{~mm}$ e um desvio de linha média dentária superior de $6 \mathrm{~mm}$ para a esquerda, além de um apinhamento nos incisivos inferiores. Em virtude da perda do incisivo lateral esquerdo devido a um odontoma, utilizourse um arco segmentado para abertura de espaço para uma prótese adesiva, por meio de um sistema de forças assimétricas. Utilizaram-se forças de intrusão e inclinação nos incisivos inferiores para correção da sobressaliência, finalizando-se 0 caso com as linhas médias dentárias coincidentes entre si. A paciente demonstrou grande satisfação com o resultado obtido.

Discutindo as implicações da assimetria dentária no diagnóstico e plano 
de tratamento ortodôntico JANSON et al.82, em 1995, descreveram um caso clínico de má oclusão de Classe II, divisão 1, subdivisão com ligeiro apinhamento superior e inferior, desvio de linha média inferior para a direita e suave protrusão labial. A paciente foi tratada com extrações de dois prémolares superiores e um pré-molar inferior, do lado da Classe I. Os resultados demonstraram que a correção de casos semelhantes com extrações assimétricas permite a obtenção de uma relação de Classe l, de caninos, com ótimo relacionamento dos dentes anteriores e coincidência das linhas médias dentárias. Obtiveram-se uma guia anterior imediata e um excelente perfil facial, comprovando a eficiência desta opção de tratamento, nestes casos.

Segundo SHROFF; LINDAUER; BURSTONE157, em 1997, a mecânica de retração unilateral constitui-se num desafio, uma vez que causa inúmeros efeitos colaterais, durante o tratamento ortodôntico. Comentaram sobre o diagnóstico diferencial e plano de tratamento das más oclusões de Classe II, subdivisão, baseando-se num tratamento biomecânico com momentos de inclinação. Preconizaram a correção da inclinação axial dos molares, utilizando a técnica do arco segmentado com momentos de retração unilateral no tratamento das assimetrias dentárias. Afirmaram que esta técnica permite a aplicação de um sistema de forças diferenciado nos lados direito e esquerdo do arco, sem que ocorram efeitos indesejáveis, tais como: inclinação do plano oclusal, extrusão e mesialização das raízes dos molares e alterações no arco inferior decorrentes do uso de elásticos de Classe II. Produziram compensações dentárias, utilizando a retração unilateral, principalmente, para corrigir a inclinação axial mesiodistal dos molares em casos de assimetrias dentárias e esqueléticas suaves.

WOHL; BAMONTE; PEARSON181, em 1998, descreveram o caso de uma paciente de 13 anos e 3 meses com Classe II, divisão 1, subdivisão esquerda, apresentando as linhas médias dentárias coincidentes com o plano sagital mediano. O arco superior encontrava-se atrésico na região anterior, com ambos os incisivos laterais lingualizados. O plano de tratamento permitiu o crescimento das bases ósseas, optando-se pela expansão do arco superior e uso da placa lábio-ativa no arco inferior. Posteriormente, realizou-se uma distalização assimétrica dos molares e retração dos caninos, para correção do trespasse horizontal de $7 \mathrm{~mm}$, com arco extrabucal assimétrico, apresentando 
maior força do lado esquerdo, além do uso dos elásticos de Classe II, totalizando 19 meses de tratamento, obtendo-se uma relação de canino e de molar em Classe I. Concluíram que o sucesso e estabilidade destes casos se devem a uma ótima cooperação por parte da paciente.

As correções ortodônticas das assimetrias dentárias geralmente constituem-se num processo complexo e desafiador, segundo SHROFF; SIEGEL ${ }^{159}$, em 1998, que avaliaram o tratamento de pacientes com assimetrias, utilizando mecânica assimétrica. Um diagnóstico diferencial meticuloso, juntamente com um plano de tratamento preciso podem levar ao sucesso da correção destas más oclusões. Assim, descreveram que a rotação e a inclinação axial dos molares, a presença de mordida cruzada posterior e a perda prematura dos dentes decíduos, constituem-se elementos chaves do diagnóstico diferencial para a detecção das possíveis assimetrias. Comentaram que se podem corrigir as más oclusões de Classe II, subdivisão de forma conservadora, com elásticos de Classe II unilaterais, molas abertas superelásticas ou cursores, jasper jamper unilateral, aparelho removível de Shamy, expansor tipo pendulum, ancoragem extrabucal assimétrica e preparo de ancoragem, com dobras distais unilaterais.

TODD et al. ${ }^{170}$, em 1999, descreveram um caso clínico de extração assimétrica da Classe II, divisão 1, subdivisão esquerda, acompanhado de uma mordida cruzada anterior e posterior. A paciente leucoderma apresentava 17 anos e 3 meses de idade, com assimetria dentária do arco inferior. Havia um desvio de um milímetro da linha média dentária superior, enquanto a inferior apresentava-se desviada cinco milímetros, ambas para a esquerda, em relação ao plano sagital mediano. A má oclusão do lado direito era de Classe I de molar e de canino, enquanto do lado esquerdo era Classe II de molar e de canino. Desta forma, o plano de tratamento consistiu em extrações de dois primeiros pré-molares superiores e de um pré-molar inferior direito. A mecânica de edgewise empregada baseou-se na utilização de aparelhos fixos, com arcos ortodônticos para a expansão do arco superior e correção da mordida cruzada anterior e posterior, realizando-se simultaneamente 0 alinhamento e nivelamento dos arcos. Retraiu-se o canino inferior direito até a obtenção da simetria bilateral do arco inferior, com a correção das linhas médias superior e inferior. Utilizaram-se elásticos intermaxilares para a obtenção de uma melhor 
intercuspidação dentária, finalizando-se o caso com Classe I de molar e de canino do lado direito e Classe II de molar, no lado esquerdo, alcançando uma sobremordida e uma sobressaliência ideais e coincidência das linhas médias superior e inferior, além da eliminação da mordida cruzada.

Objetivando avaliar as alterações dentoesqueléticas decorrentes do tratamento ortodôntico, $\mathrm{CRUZ}{ }^{40}$, em 2000, comparou um grupo de pacientes com má oclusão de Classe II, subdivisão de Angle, tratados com extrações assimétricas em relação a um grupo controle de oclusão normal. A amostra consistiu de três grupos, com 30 pacientes cada, apresentando as seguintes características: grupo 1 - indivíduos com Classe II, subdivisão, não tratados; grupo 2 - pacientes com Classe II, subdivisão, tratados com extrações assimétricas; grupo 3 - indivíduos com oclusão normal. Todos apresentavam os dentes permanentes superiores e inferiores, em ambos os arcos dentários, até os primeiros molares, no início do tratamento. A idade média da amostra foi de 15,76, 18,57 e 22,42 anos nos grupos de Classe II, subdivisão não tratado, Classe II, subdivisão tratado e oclusão normal, respectivamente. Medidas de diferenças relativas da posição espacial de pontos dentários e esqueléticos bilaterais foram obtidas nas radiografias submentoniana e póstero-anterior. $\mathrm{O}$ teste t para amostras independentes foi utilizado para comparar os grupos $1 \mathrm{e}$ 2 com o grupo 3, em tempos diferentes. Considerou-se que o grupo 2 tinha apresentado uma melhora se as variáveis do grupo 1, que tiveram uma diferença estatisticamente significante com 0 grupo 3 , não fossem estatisticamente diferentes do grupo com oclusão normal. Os resultados nas radiografias submentonianas demonstraram que as extrações assimétricas nas más oclusões de Classe II, subdivisão acentuaram as diferenças nas posições ântero-posteriores direita e esquerda, dos primeiros molares superiores e inferiores, como esperado com estes protocolos de extrações. Não houve alterações esqueléticas significantes que pudessem ser atribuídas às formas de tratamento investigadas e nem efeitos colaterais transversais com as mecânicas assimétricas empregadas. Também foi demonstrado que 0 tratamento da Classe II, subdivisão com extrações assimétricas normaliza o posicionamento das linhas médias superior e inferior sem causar inclinação do plano oclusal ou de qualquer outro plano horizontal pesquisado, na análise da radiografia póstero-anterior. Portanto, concluiu-se que o tratamento da Classe 
II, subdivisão com extrações assimétricas constitui uma modalidade terapêutica válida para a solução deste problema.

Em 2000, SHELLEY et al.155 apresentaram um caso de Classe II, divisão 2, subdivisão com mordidas cruzadas anteriores e posteriores, em virtude de perdas prematuras dos segundos molares decíduos superiores que ocasionaram uma maior mesialização do primeiro molar superior esquerdo, causando uma assimetria do arco superior. Utilizourse uma placa de mordida posterior, para descruzar a mordida, além de mentoneira para controlar 0 crescimento anterior da mandíbula e realizourse extração do primeiro pré-molar superior esquerdo. Corrigiu-se a aparência prognata do lábio inferior, resultando em um perfil ligeiramente convexo. Obteve-se uma relação de Classe I de caninos e de molar direito e relação de Classe II de molar esquerdo, com guia canino durante excursões laterais e coincidência da oclusão cêntrica e relação cêntrica, além da correção da discrepância de linha média. Caso se tivesse utilizado mantenedor de espaço na época das perdas prematuras dos molares decíduos, o caso poderia ter sido tratado sem extração.

De acordo com investigações clínicas de WARREN173, em 2001, quase todos casos de má oclusão de Classe II, subdivisão apresenta algum grau de discrepância entre oclusão cêntrica e relação cêntrica. A maioria dos casos de subdivisão envolve um desvio mandibular em vez de um simples desvio dentário. Quando se detecta este desvio, a primeira meta deve ser destravar a mandíbula (eliminando interferências) e centralizá-la, liberando-a nos três planos do espaço, pois este alinhamento permite o correto diagnóstico. Apresentou 3 casos de má oclusão de Classe II, subdivisão em que havia desvio mandibular e a não coincidência da oclusão cêntrica e relação cêntrica. Nos três casos, realizou-se expansão do arco superior para liberar a mandíbula. Dois foram tratados sem extrações e um com extração dos primeiros pré-molares superiores. Em um dos casos sem extrações, utilizourse elástico de Classe II, unilateralmente, associado à ancoragem extrabucal cervical, totalizando 30 meses de tratamento. No segundo caso sem extrações, utilizourse ancoragem extrabucal cervical, elástico de Classe II, de Classe III e elástico diagonal anterior, finalizando o tratamento também em 30 meses. No outro caso, optourse pelas extrações dos primeiros pré-molares superiores e 
utilização de elástico de Classe II, de Classe III e elástico diagonal anterior, com duração de 24 meses de tratamento.

\subsubsection{1 - Mecânicas assimétricas empregadas na correção da Classe II, subdivisão}

Nos casos de pacientes em crescimento, em que o desvio ânteroposterior não seja tão acentuado, a ancoragem extrabucal unilateral também atua na correção da Classe II, subdivisão79,159. Entretanto, HERSHEY; HOUGHTON; BURSTONE ${ }^{71}$, em 1981, comentaram que embora este aparelho seja efetivo na produção da força de distalização unilateral, o braço interno do arco tende a criar uma mordida cruzada do lado onde se está recebendo a maior força. Além disso, a necessidade de colaboração por parte do paciente constitui em uma das limitações deste aparelho 79,159.

Com relação ao tratamento sem extrações, CETLIN; TEN HOEVE³, em 1983, relataram que o aparelho removível de Shamy, para a correção unilateral da má oclusão de Classe II também apresenta vantagens e desvantagens. Os aparelhos removíveis, assim como os elásticos de Classe II, dependem da cooperação por parte do paciente para se obter o sucesso ao final do tratamento. $\mathrm{O}$ aparelho de Shamy utiliza todo o arco dentário superior como ancoragem, possuindo uma mola de distalização unilateral que serve para corrigir a relação de Classe II, subdivisão. Para os autores, um dos efeitos colaterais deste tratamento conservador implica na grande perda de ancoragem e conseqüente mesialização dos dentes ântero-superiores, podendo ser ou não um efeito desejável.

Outra maneira de se corrigir a Classe II unilateral, de acordo com GIANELLY; BEDNAR; DIETZ58, em 1991, consiste na utilização de molas abertas ou cursores que distalizam o molar unilateralmente, corrigindo sua inclinação axial mesiodistal. Esta distalização unilateral do molar superior torna-se mais aplicável antes da erupção dos segundos molares. As molas distribuem uma força distal para a coroa do molar, além de um momento distal e uma força mesial para os pré-molares e caninos, inclinando estes dentes para anterior. Como reforço de ancoragem no arco superior, deve-se empregar botões de Nance, podendo ainda se utilizar elásticos de Classe II unilaterais, simultaneamente, visando contrabalançar a força mesial ocasionada pelas 
molas ${ }^{159}$. Novamente, surgem efeitos colaterais indesejáveis desta mecânica, como o componente extrusivo dos elásticos de Classe II, a descoordenação dos arcos e a abertura de diastemas nos incisivos inferiores 30,159 .

O aparelho tipo jasper jumper, quando ativado unilateralmente, tem sido empregado para a correção da Classe II, unilateral. Em 1991, BLACKWOO21 e COPE et al.39, em 1994, recomendaram que a utilização deste aparelho geralmente deve ser realizada com um fio redondo contínuo, no arco superior, e um fio retangular espesso, no arco inferior. O molar superior não somente sofre uma distalização, como também uma intrusão. Como resultado do ponto vestibular de aplicação da força intrusiva, o molar superior pode se inclinar vestibularmente, aumentando ainda mais a sobressaliência lateral. No arco inferior, a seção anterior do arco sofre uma força mesial e intrusiva. Isto promove uma inclinação do plano oclusal ântero-inferior, intruindo os dentes anteriores do lado em que há a correção da Classe II, abrindo diastemas nos incisivos inferiores. A falta de relacionamento entre os arcos ocorre devido à aplicação unilateral do sistema de forças, criando uma sobressaliência assimétrica e uma discrepância excessiva de linha média159. A utilização unilateral do jasper jumper pode ser vantajosa nestas situações clínicas, auxiliando na correção das linhas médias. O controle da posição dos incisivos inferiores e a ancoragem do arco inferior podem ser incrementados pela inclusão dos segundos molares no arco retangular e pela incorporação de torque lingual de coroa nestes dentes ${ }^{159}$.

O expansor fixo tipo pendulum pode ser utilizado na correção das más oclusões suaves de Classe II, subdivisão. Este aparelho dentomucosuportado ancora-se no palato, apresentando molas de beta-titânio TMA desenvolvidas para distalizar os molares unilateralmente ou bilateralmente. Entretanto, apresenta 0 inconveniente de dificultar o controle da ancoragem na região anterior do arco' ${ }^{159}$.

A utilização de elásticos de Classe II unilaterais para os casos suaves de Classe II, subdivisão, causam efeitos indesejáveis que dependem da magnitude e do ponto de aplicação da força, bem como do tempo de duração da sua utilização $30,157,159$. Alterações significantes do plano oclusal maxilar anterior, resultantes do componente vertical dos elásticos de Classe II extruem o lado do arco onde o elástico está sendo utilizado. O plano oclusal do lado da 
correção sofre também uma inclinação acentuada em decorrência das forças verticais aplicadas nas porções ântero-superiores e póstero-inferiores, tornando a estabilidade do tratamento questionável, especialmente quando não ocorre um crescimento adequado. Uma descoordenação dos arcos pode se desenvolver, juntamente com uma abertura de diastemas nos incisivos inferiores ${ }^{30,159}$. Além disso, o primeiro sinal da ocorrência destes efeitos colaterais consiste no aparecimento de uma sobressaliência assimétrica $30,157,159$.

Pode-se utilizar elásticos de Classe II e Classe III, associados a um elástico diagonal anterior para tratar as discrepâncias menores de coordenação de linha média nos estágios finais $3,79,97,134$. Entretanto, se os arcos apresentarem formas assimétricas, talvez haja a necessidade de se utilizar elásticos intermaxilares cruzados nas regiões de caninos e pré-molares, com a forma do arco distorcida no sentido oposto 160 .

Em virtude de muitos casos de subdivisão apresentarem-se associados a uma sobremordida profunda, pode-se corrigir o segmento anterior pelo movimento de intrusão e, simultaneamente, pela posição anterior destes molares, distalizando-os por meio de momentos de força ${ }^{159}$. Quando se deseja que forças de distalização assimétricas bilaterais sejam implementadas, podese recorrer à combinação de três segmentos de arcos-base $30,157,158$. As molas de distalização são acopladas bilateralmente nas extensões distais do segmento rígido anterior do arco conectado aos quatro dentes anteriores. Considera-se o ponto de aplicação de força no segmento anterior do fio, o centro de resistência dos dentes ântero-superiores, promovendo uma intrusão controlada na inclinação axial dos quatro incisivos, enquanto os molares sofrem distalização e extrusão bilateral e os pré-molares e caninos são encorajados a se movimentarem para distal, consecutivamente. À medida que os molares distalizam, os ganchos destas molas deslizam para trás da extensão do fio anterior, mudando o ponto anterior de aplicação de força, necessitando uma constante monitoração da posição destes ganchos, durante o tratamento. Em situações de inclinação axial do molar unilateral, pode-se combinar a técnica segmentada com a utilização dos arcos transpalatinos. Após a correção unilateral da inclinação axial do molar, estando a oclusão dos lados direito e esquerdo smétrica, o tratamento ortodôntico pode prosseguir 
com a mecânica simétrica nos quatro quadrantes ${ }^{159}$.

MANDURINO; BALDUCCI102, em 2001, descreveram a confecção e utilização de um arco transpalatino de TMA para distalização do molar superior em caso de Classe II, subdivisão. Segundo os autores, tal método apresenta vantagens em relação a outros aparelhos para distalização de molares, pois o fio TMA apresenta melhor memória de forma e resiliência que o fio de aço; o arco apresenta uma simples construção; o sistema é higiênico e econômico; não há perda de ancoragem anterior e os pré-molares e caninos seguem espontaneamente o molar para distal. No entanto, como há uma maior rotação mesiovestibular do molar de ancoragem, deve-se utilizá-lo com o aparelho fixo na fase de arco retangular de aço, além do uso de força extrabucal noturna para reforçar ancoragem.

Um arco facial reforçado unilateralmente para correção assimétrica foi proposto por SKINAZI162, em 2001. Algumas más oclusões de Classe II apresentam-se claramente assimétricas, por isso os molares superiores necessitam ser distalizados mais de um lado que do outro. Descreve um caso clínico em que utilizou um AEB cervical com braços externos curtos e simétricos, ajustando os ângulos entre os braços externo e interno. Após umas seis a oito semanas, quando o paciente já havia se acostumado com o aparelho, soldourse uma barra rígida entre os arcos interno e externo no lado que necessitava de uma maior distalização. Concluiu que o arco facial reforçado sofre menos deformação que o lado oposto, aumentando assim a pressão no lado reforçado, potencializando a distalização assimétrica.

\subsubsection{2 - Correção do desvio da linha média}

Um dos problemas mais comuns e persistentes que os ortodontistas se deparam constituem-se nos desvios da linha média. Podem ser verificados em todos os tipos de casos, porém parecem ser vistos mais freqüentemente nas más oclusões de Classe II. A coordenação das linhas médias assume grande importância no plano de tratamento ortodôntico e a complexidade de sua correção aumenta de acordo com a duração da terapia. O desvio da linha média por si só não constitui o principal problema, mas é um indício de que a oclusão não se apresenta bilateralmente correta. Portanto, ao se corrigir a má oclusão posterior associada, geralmente se corrige o desvio da linha média97. 
A coincidência das linhas médias dentárias superior e inferior consiste num objetivo a ser estabelecido no tratamento ortodôntico para que haja uma intercuspidação satisfatória e uma harmonia dentária59. A avaliação da estética facial consiste num componente importante do plano de tratamento ortodôntico e a simetria consiste num dos mais relevantes fatores na definição de um sorriso atraente ${ }^{19,75}$. Enquanto a assimetria compromete a estética dentária19. Por esta razão, a posição das linhas médias deve receber total atenção durante a terapia ortodôntica.

A preocupação em se corrigir as discrepâncias de linha média existe desde o princípio da Ortodontia, quando ANGLE6, em 1907, utilizou o elástico de Classe III e o elástico diagonal anterior ambos associados a uma expansão do arco dentário, para a correção das discrepâncias de linha média.

A maioria dos casos que termina muito aquém de um resultado ideal decorre de discrepâncias laterais entre as linhas médias dentárias superior e inferior, segundo BREAKSPEAR ${ }^{25}$, em 1963. Nestes casos, deve-se realizar um ajuste oclusal que pode ou não corrigir a assimetria dentária ou facial. Assim, sempre se deve priorizar a finalização dos casos com a coincidência das linhas médias do que se deparar com este problema após o término do tratamento ativo.

BUCHIN26, em 1967, afirmou que as discrepâncias de linha média são fáceis de serem corrigidas e não constituem um grande problema. Entretanto, a correção torna-se difícil de ser mantida quando a discrepância for causada por uma assimetria esquelética. Quando em presença de desvios de linha média decorrentes de assimetrias dentárias a linha média inferior geralmente se encontra desviada para o lado da relação de Classe I. No tratamento da má oclusão de Classe II, divisão 1, subdivisão, utiliza-se um elástico de Classe II de um lado, um de Classe III do outro e um elástico cruzado anterior, dispostos paralelamente, sendo o anterior, provavelmente, o mais importante. Desta forma, com o nivelamento e remoção das interferências cuspídicas, a má oclusão passa a ser uma 1/2 Classe II, divisão 1, bilateral. A correção completa do caso, até a obtenção da chave de canino em Classe I, com a utilização dos elásticos intermaxilares pode ser obtida em 8 a 10 semanas com ligeira sobrecorreção.

Durante o tratamento ortodôntico, os dentes devem ser posicionados em 
busca de uma harmonia dentoesquelética, de acordo com GIANELLY; PAUL 59, em 1970. Por isso, as posições finais dos dentes devem assumir uma relação oclusal de Classe I, com um perfeito alinhamento, contato proximal, inclinações axiais adequadas e intercuspidação máxima. Assim como os dentes superiores e inferiores devem apresentar um perfeito relacionamento, as linhas médias superior e inferior devem estar coincidentes, havendo uma quantidade semelhante de material dentário em cada hemiarco. Comentaram que se as linhas médias não estão coincidentes, a intercuspidação máxima torna-se improvável, porque a posição das cúspides no lado em que está o desvio da linha média localiza-se mais posteriormente, enquanto que a do lado oposto, as cúspides situam-se mais anteriormente. Afirmaram que nos casos em que o arco superior apresenta coincidência de linha média dentária e o inferior apresenta desvio, ambos em relação ao plano sagital mediano; deve-se utilizar o arco superior como unidade de ancoragem, estabilizando-o com um arco retangular passivo para a correção do desvio de linha média dentária inferior. Concluíram que a utilização do sistema de elásticos de Classe II e III, propostos por BUCHIN26 corrige a discrepância de linha média em, no máximo, dois meses. Enfatizaram a necessidade do controle da inclinação das raízes para complementação dos casos, além da incorporação de dobras de segunda ordem nos caninos e nos molares.

Em um trabalho realizado sobre o desvio da linha média, LEWIS ${ }^{97}$, em 1976, comentou a escassez de publicações a respeito das possíveis causas destas discrepâncias e como elas influenciam a má oclusão. Apresentou uma lista de fatores responsáveis pelo desvio da linha média: 1) mordida cruzada posterior associada ao desvio mandibular; 2) inclinação e/ou migração dos dentes anteriores superiores e/ou inferiores; 3) desvio lateral mandibular, sem mordida cruzada (rotação mandibular resultante de interferências oclusais); 4) arcos assimétricos; 5) discrepâncias de tamanho dentário e a combinação dos quatro primeiros itens. Desta forma, a assimetria, as discrepâncias de linha mediana e os desvios mandibulares jamais se auto-corrigem, devendo ser analisados cuidadosamente e tratados, para a obtenção da estética e estabilidade dos casos. Argumentou que a correção de um desvio de linha média, causado pelo suave desvio da mandíbula, nos casos em que não há mordida cruzada, geralmente torna-se mais fácil nos estágios finais do 
tratamento. Deste modo, recorre-se à utilização simultânea de elásticos de Classe II, tracionando este lado anteriormente e elástico diagonal anterior, corrigindo a posição mandibular e dentária para o centro da face. Quando a mordida cruzada posterior está presente, indica-se primeiramente o seu descruzamento, corrigindo posteriormente a linha média desviada. LEWIS ${ }^{97}$ ainda recomenda a utilização de mecânica com molas de distalização em vez de dobras de segunda ordem, associadas a cursores e elásticos de Classe II, para distalizar os dentes póstero-superiores em casos de arcos assimétricos. Comentou ainda que os dentes superiores, do lado de Classe II, devem ser distalizados um a um até que haja a coincidência das linhas médias.

Em 1977, BEGG; KESLING12 comentaram que o equilíbrio dos elásticos de retração, associados a uma tração de Classe II adequada, durante o estágio 2 , mantêm as linhas médias coordenadas entre si. Afirmaram também que há a possibilidade de aumentar a ação dos elásticos de Classe II unilaterais, do diagonal anterior e de Classe III com molas de verticalização que promovem a movimentação dos dentes, efetuando mudanças na linha média.

Objetivando determinar se a atratividade de adultos jovens seria modificada pela sua aparência estética, SHAW et al. ${ }^{153}$, em 1985, investigaram as implicações estéticas das más oclusões na aparência dentofacial. Utilizaram cinco diferentes disposições fotográficas, em preto e branco, de dois homens e duas mulheres, modificando-as de modo que, em cada versão a face era padronizada, excetuando o problema estético dentário. Os cinco tipos de face de cada paciente diagramadas artificialmente apresentaram os seguintes problemas: incisivos bem posicionados, incisivos proeminentes, incisivo lateral superior ausente, incisivos excessivamente apinhados e fenda labial unilateral. Oitocentos adultos foram convocados para julgar estas 20 faces, utilizando escores para estimar a característica individual social de cada face. Concluíram que as faces com os incisivos proeminentes receberam conceitos de fidelidade e honestidade, enquanto que as faces com fissura unilateral receberam os menores pontos de estética facial. As faces que apresentavam os incisivos alinhados e nivelados apresentaram mais atratividade, socialização, popularidade e sinônimo de inteligência. Desta forma, afirmaram que os pacientes que apresentavam dentes bem posicionados eram mais atraentes socialmente. 
Em 1986, PROFFIT134 afirmou que as discrepâncias menores de coordenação de linha média podem ser tratadas nos estágios finais com elásticos assimétricos de Classe II e de Classe III, evitando-se o máximo os elásticos unilaterais. Os elásticos intermaxilares de Classe II ou de Classe III associados a um elástico diagonal anterior podem ser necessários para a finalização ideal dos casos, entretanto, após o fechamento dos espaços de extração, a correção de discrepâncias acentuadas torna-se complexa.

O uso de elástico diagonal anterior associado aos elásticos de Classe II ou III foi preconizado por ALEXANDER ${ }^{3}$, em 1987, em más oclusões de Classe II ou III, respectivamente. Realiza-se este procedimento, na maioria dos casos, durante os estágios de finalização. Com exceção dos planejamentos com extração em que se deve utilizar durante o fechamento dos espaços, juntamente com o elástico diagonal anterior, quando houver uma discrepância significante de linha média.

Em 1990, JERROLD; LOWENSTEIN83 salientaram que as três linhas médias do paciente: a facial, a maxilar e a mandibular devem ser avaliadas para o diagnóstico e o tratamento adequados dos casos. A coordenação das linhas médias e a simetria facial constituem a base para uma face harmoniosa e agradável. A máxima intercuspidação, a função e a estabilidade dos resultados, as estéticas facial e dentária anterior e a diminuição da potencialidade das disfunções temporomandibulares constituem-se as metas propostas para se obter o sucesso dos casos. O correto diagnóstico diferencial da discrepância permite que $\mathrm{o}$ profissional utilize mecânicas inter e intramaxilares para a resolução dos desvios da linha média. A correção da linha média deve começar desde o início do tratamento e após sua coordenação, devem ser mantidas como referencial para qualquer sistema de força utilizado na finalização dos casos. Quando a discrepância de linha média é suave entre um a dois milímetros, pode-se inclinar os dentes anteriores numa posição que coincida com a linha média facial. Se a linha média inferior se encontra desviada para o lado oposto, deve-se corrigi-la por inclinação. As molas de verticalização, juntamente com elásticos diagonais anteriores podem ser adaptadas para se obter uma coincidência das linhas médias, com a simetria dos incisivos em relação ao plano sagital mediano. A estética resultante deste procedimento é geralmente desfavorável, embora dependa da 
posição dos lábios do paciente, da linha do sorriso e da quantidade de dentes que foram inclinados. A retração acentuada dos caninos constitui-se numa causa do desvio de linha média, ocorrendo quando o profissional não fica atento à obtenção da coincidência das três linhas médias do paciente. Concluíram que a maioria das formas de tratamento parece associar a discrepância de linha média como sendo resultante de um desvio ou qualquer rotação mandibular. Entretanto, quando o desvio de linha média resulta de uma migração dentária, em uma face simétrica, o emprego dessas mecânicas pode alterar a posição mandibular, obtendo-se linhas médias dentárias coincidentes, porém uma face assimétrica.

Avaliando o tratamento do desvio de linha média em uma paciente adulta, SCHUDY150, em 1996, afirmou que a largura dos arcos superior e inferior determina a posição funcional mandibular. Se o arco inferior é mais largo que o arco superior, o paciente oclue em habitual em um ou outro lado, podendo desenvolver uma mordida cruzada. Da mesma maneira ocorre com o arco superior. Quando os dentes posteriores ocluem cúspide-cúspide em vez de cúspide-fossa, até pequenos movimentos habituais da mandíbula para um lado ou outro podem induzir uma mordida cruzada. Desta forma, apresentou um caso de uma paciente com 42 anos de idade, com má oclusão de Classe II, subdivisão, desvio da linha média inferior, discrepância do arco inferior, sobremordida profunda e sobressaliência severa. Corrigiu-se a má oclusão enquanto o côndilo direito foi deliberadamente movimentado para anterior com elásticos utilizados diariamente, durante dez meses. Após dez anos do tratamento, verificou-se uma estabilidade do caso, apresentando uma Classe I de molar, com discrepância corrigida, além da correção da sobressaliência e da sobremordida acentuadas. A estética e a função da má oclusão corrigida mostraram-se satisfatórias tanto para a paciente como para o autor. $O$ tecido periodontal apresentourse saudável e ambas as ATMs apresentaram espaços articulares adequados, suave contorno das superfícies ósseas e ausência de sintomatologia dolorosa.

Em 1998, ERDOGAN; ERDOGAN48 descreveram dois casos clínicos que apresentavam uma Classe II, subdivisão, sendo necessária uma mecânica assimétrica para o tratamento. Ambos os casos mostravam assimetria facial moderada, desvio mandibular para um dos lados, perfil mole e sorriso normais. 
Utilizaram o jasper jumper assimetricamente, com a mecânica convencional de Classe II de um lado e uma mecânica de Classe III do outro, para corrigir a discrepância de linha média e um possível desvio mandibular, resultante de uma deficiência maxilar. Descreveram os efeitos dentoesqueléticos deste tipo de tratamento em um caso, na fase inicial da dentadura permanente, e outro, num paciente adulto. Os efeitos dentários deste sistema de força são recíprocos, ou seja, os incisivos movimentam-se de corpo em direções opostas, enquanto a direção e a quantidade do movimento são controladas pelo tamanho dos jumpers. Houve boa aceitação dos aparelhos pelos pacientes e nenhum índice de quebra foi registrado, mesmo tendo sido acoplados mesialmente aos tubos dos molares. Além de que houve menor manifestação de efeitos adversos em comparação com o uso dos elásticos intermaxilares. Concluíram que em ambos os casos houve a correção das assimetrias dos arcos dentários e a estabilidade dos resultados.

A posição da linha média dentária superior denota um dos mais importantes aspectos de diagnóstico no plano de tratamento ortodôntico. Entretanto, a obtenção da coincidência das linhas médias dentárias com a linha média facial pode ser de difícil obtenção, dependendo do paciente. Além disso, quando não há o alinhamento de outras linhas médias faciais, a avaliação da posição da linha média dentária pode se tornar complexa. Por esta razão, BEYER; LINDAUER ${ }^{17}$, em 1998, propuseram-se a estudar duas implicações: 1-) verificar até quanto a linha média dentária superior pode se desviar da linha média facial e ainda ser considerada esteticamente aceitável e 2-) determinar como as posições dos vários pontos faciais medianos afetam a estética facial, de um modo geral. Cento e vinte examinadores, incluindo 30 ortodontistas, 30 clínicos gerais e 30 pais de pacientes, avaliaram as imagens digitalmente alteradas de dois casos, para determinar a aceitabilidade dos desvios de linha média dentária e priorizar a importância da localização de várias estruturas da linha média facial. Em relação à aceitabilidade do desvio da linha média, os ortodontistas foram mais críticos do que os clínicos gerais e os pais. Quando se avaliaram os desvios das várias estruturas das linhas médias, fotografias apresentando desvios das linhas médias superior e/ou desvios nasais foram consideradas menos estéticas. Concluíram que as diferenças encontradas neste estudo mostraram grandes graus de aceitabilidade de desvio da linha 
média entre os pacientes. Além disso, o mesmo desvio de dois ou três milímetros pode ser considerado aceitável em uma pessoa e inaceitável em outra, dependendo da sua relação com outros pontos faciais.

Quando há uma discrepância da linha média superior e inferior, sem a presença de discrepância apical, o tratamento torna-se simplificado, pois se pode utilizar forças simples para inclinar os dentes, corrigindo as linhas médias correspondentes, não produzindo efeitos colaterais quando aplicadas adequadamente. Inversamente, quando há uma discrepância verdadeira da base apical, a mecânica torna-se mais complexa, ocorrendo uma restrição na movimentação dentária mesiodista|30.

O impacto que a estética dentária exerce na atratividade facial foi abordado por inúmeros trabalhos 17,24,75,84,153. Em 1999, JOHNSTON; BURDEN; STEVENSON84 investigaram a percepção das discrepâncias entre as linhas médias dentária e facial, por meio de uma análise visual realizada por 20 ortodontistas e 20 leigos jovens. Utilizaram uma imagem fotográfica do sorriso de uma jovem, com a mesma expressão facial, modificando-se a linha média dentária em relação à linha média facial. Assim, pôde-se julgar o grau de atratividade do sorriso desta imagem, utilizando-se notas com escala de escores de dez pontos. Como resultados, verificaram que as imagens menos atraentes tanto para os ortodontistas como para os leigos relacionaram-se com o aumento da discrepância entre as linhas médias dentária e a facial. Concluíram que os ortodontistas eram mais sensíveis que as pessoas comuns no que concerne às discrepâncias menores entre as linhas médias dentária e facial. Além disso, calcularam que a probabilidade dos leigos considerarem um menor escore de atratividade era de $56 \%$, enquanto que para os ortodontistas era de $83 \%$, quando havia uma diferença de $2 \mathrm{~mm}$ entre as linhas médias dentária e a facial. Assim, afirmaram que todo tratamento ortodôntico deve incluir a correção completa das discrepâncias das linhas médias dentárias superior e inferior, tolerando-se para os casos mais severos, até no máximo $2 \mathrm{~mm}$ de discrepância entre estas linhas, pois valores superiores a este terão um efeito negativo na estética dentofacial. 


\subsection{3 - Tratamento ortodôntico-cirúrgico das más oclusões assimétricas}

Há diferentes modalidades de cirurgias empregadas para a correção dos variados tipos de assimetria que serão aplicadas conforme a necessidade do caso. Os casos que apresentam falta de desenvolvimento do ramo ascendente, pode-se utilizar enxerto ósseo122,183; a condilectomia aplica-se aos casos com hiperplasia condilar ${ }^{9}$; em casos de assimetria mandibular, pode-se utilizar a técnica de Obwegeser II, de um lado e Obwegeser-Dal Pont, do outro110. As osteotomias Le Fort I e em L invertido ${ }^{183}$ aplicam-se aos casos de assimetria maxilar e mandibular, respectivamente. Já nos casos em que a dentadura não se apresenta tão assimétrica quanto a mandíbula, realiza-se apenas uma genioplastia135.

Em 1998, YAMASHIRO; OKADA; TAKADA ${ }^{183}$ descreveram o tratamento cirúrgico de dois casos clínicos que exibiam assimetria dentofacial, incluindo desvio mandibular e inclinação da maxila. Nos dois casos houve fratura condilar no período pubescente. No primeiro caso, a paciente sofreu uma fratura condilar esquerda aos seis anos de idade, sendo controlada durante três anos. Aos 25 anos procurou tratamento ortodôntico, pois apresentava dificuldade em realizar o movimento de abertura bucal, sendo submetida a um implante de silicone na região condilar. Para a correção da assimetria facial severa, do retrognatismo mandibular, do apinhamento superior e inferior, do desvio esquerdo do mento de sete milímetros e dos movimentos bordejantes mandibulares limitados, recorreurse à terapia combinada ortodôntica-cirúrgica para eliminar o problema dentário e amenizar o esquelético. O segundo caso apresentava uma suave assimetria facial e mandibular, mordida aberta anterior e apinhamento dentário em ambos os arcos, além de um desvio do mento de dois milímetros para o lado esquerdo. Como esta paciente apresentava 12 anos na consulta inicial, tendo história de fratura condilar aos 9 anos, planejaram um tratamento ortopédico até 0 final do crescimento, posteriormente, extraiu-se os primeiros pré-molares superiores e inferiores, durante o tratamento ortodôntico pré-cirúrgico. Mais tarde, implementou-se um reposicionamento cirúrgico maxilomandibular para a finalização do tratamento com a ortodontia pós-operatória. Em ambos os casos, houve, além da correção dos arcos dentários, uma melhora da assimetria e do perfil facial.

Em estudo sobre a correção cirúrgica de pacientes com assimetrias, 
LEGAN92, também em 1998, comentou que a hiperplasia condilar, em seu estágio inicial, apresenta uma mordida aberta no lado afetado, pois a erupção dentária não acompanha o crescimento mandibular. Nos casos mais severos, os dentes geralmente ocluem bilateralmente, mas o plano oclusal frontal encontra-se inclinado e muitas regiões da maxila, da mandíbula e do mento apresentam assimetria. O tratamento destes casos consiste em uma osteotomia segmentada Le Fort I para diferenciar a impacção da maxila dos lados direito e esquerdo, além da expansão do arco. Comentou que a osteotomia bilateral do ramo e a condilectomia devem ser realizadas para rotacionar a mandíbula do lado hiperplásico e uma genioplastia deve ser implementada para a correção da posição do queixo. O diagnóstico e o tratamento precoce da hiperplasia condilar previnem muitas deformidades secundárias, como a inclinação do plano oclusal frontal maxilar. Em pacientes adultos, a cirurgia intracapsular no côndilo mandibular geralmente não se torna necessária, mas as osteotomias maxilar e mandibular são requeridas. A osteotomia Le Fort I para o reposicionamento superior do lado afetado e as osteotomias bilaterais do ramo mandibular corrigem a angulação do plano oclusal, além de servirem, simultaneamente para a correção das discrepâncias ântero-posterior, vertical e transversal associadas. A genioplastia para correção da assimetria do mento, a osteotomia da borda inferior da mandíbula para a correção do lado afetado e/ou o aumento do bordo inferior do lado contralateral devem ser indicadas. Muitos casos ortodôntico-cirúrgicos assimétricos constituem variações de outras deformidades hipo ou hiperplásicas da mandíbula, devendo ser tratados pelo movimento assimétrico do segmento distal mandibular, utilizando osteotomias bilaterais do ramo. Os dois procedimentos cirúrgicos mais freqüentes compõem-se do corte sagital do ramo mandibular e osteotomia do ramo vertical intrabucal. Às vezes, o paciente com o côndilo hiperplásico beneficia-se da condilectomia para corrigir a assimetria mandibular e, freqüentemente, a forma e a posição maxilar devem ser corrigidas, necessitando de osteotomias maxilar e mandibular. A genioplastia, a mandibuloplastia, o aumento ou a redução do tecido mole e do bordo inferior mandibular contribuem adicionalmente na correção das assimetrias. A terapia ortodôntica direciona idealmente os dentes no osso basal. Indica-se a biomecânica do arco segmentado, particularmente, quando o 
planejamento cirúrgico necessita de osteotomia, bem como da precisão no nivelamento pela intrusão, retração com ancoragem máxima, torque segmentado e quando a inclinação e/ou controle das dimensões transversais tornam-se requeridas. O planejamento ortodôntico e o controle biomecânico como o alinhamento, o nivelamento o fechamento do espaço, o controle da largura do arco, o torque e a inclinação devem ser monitorados como objetivos cirúrgicos.

\section{Conclusões da Revisão de Literatura:}

1 - A assimetria craniofacial ocorre freqüentemente na maioria da população e independe da má oclusão. Grande parte dos trabalhos não evidencia uma maior assimetria craniofacial em indivíduos com más oclusões inespecíficas, comparando-se com indivíduos com oclusão normal.

2 - Dentre as causas das assimetrias dentofaciais, incluem-se: as más formações genéticas ou congênitas, como a microssomia hemifacial; fatores ambientais, como o trauma; desvios funcionais; desvios mandibulares resultantes de interferências dentárias; fatores epigenéticos e adquiridos, como infecções ou patologias.

3 - Com relação à Classe II, subdivisão, a maioria dos estudos também não evidenciou uma assimetria esquelética maior em relação a indivíduos com oclusão normal. Muitos trabalhos correlacionam a Classe II, subdivisão com uma maior assimetria dentoalveolar, sendo decorrente, principalmente, do posicionamento mais distal do primeiro molar inferior, do lado da Classe II.

4 - Utilizam-se diversos métodos para identificar e quantificar a magnitude das assimetrias, como uma avaliação frontal por meio do exame clínico ou de fotografias faciais frontais padronizadas, além de avaliações radiográficas, utilizando-se radiografias póstero-anteriores e submentonianas.

5 - O tratamento ortodôntico da Classe II, subdivisão, deve, na maioria das vezes, apresentar uma abordagem com mecânica ou extrações assimétricas, corrigindo, conseqüentemente, as discrepâncias das linhas médias superior e inferior, estabelecendo uma intercuspidação satisfatória e uma harmonia dentária.

Planejou-se este trabalho, objetivando esclarecer algumas questões à 
respeito da Classe II, subdivisão, como a prevalência dos dois tipos principais de Classe II, subdivisão (tipo 1 - causado pelo posicionamento distalizado do molar inferior, do lado da Classe II e tipo 2 - causado pelo posicionamento mesializado do molar superior, do lado da Classe II), refletidas na porcentagem dos desvios das linhas médias dentárias, em relação ao plano sagital mediano, relacionando-os com a possível existência de assimetria dentoesquelética. 
3. Proposiçãao 


\section{3 - Proposição}

Este trabalho visa determinar, por meio de avaliação frontal fotográfica, a prevalência dos tipos principais de Classe II, subdivisão em uma população com este tipo de má oclusão.

Objetiva também verificar a ocorrência de assimetrias dentoesqueléticas nos dois tipos distintos de Classe II, subdivisão, utilizando radiografias submentonianas e póstero-anteriores, pela comparação com um grupo de oclusão normal. 


\section{Materiale Métodos}




\section{4 - Material e Métodos:}

\section{1 - Material:}

A amostra consistiu de dois grupos: o grupo experimental com 44 indivíduos que apresentavam má oclusão de Classe II, subdivisão com Classe II completa, de um lado e Classe I, do outro (FIGURA 1), sendo 23 do gênero masculino e 21 do feminino, com idade média de 15,3 anos; e o grupo controle com 30 indivíduos que apresentavam oclusão normal (FIGURA 2), selecionados dentre estudantes e funcionários da Faculdade de Odontologia de Bauru, sendo 10 do gênero masculino e 20 do feminino, com idade média de 22,42 anos. Desses grupos, 30 indivíduos com má oclusão de Classe II, subdivisão e os 30 indivíduos com oclusão normal já estavam disponíveis, catalogados por meio de fotografias, radiografias submentonianas e pósteroanteriores, em pesquisa realizada anteriormente ${ }^{79}$. Os outros 14 foram selecionados dentre os 600 indivíduos que procuraram tratamento ortodôntico na Disciplina de Ortodontia da Faculdade de Odontologia de Bauru-USP e também foram catalogados por meio de fotografias, radiografias submentonianas e póstero-anteriores.

O critério básico de seleção foi que os indivíduos deveriam apresentar todos os dentes permanentes superiores e inferiores, em ambos os arcos dentários, até os primeiros molares $2,79,104,141,152$. Como critérios adicionais, incluíram-se: ausência de tratamento ortodôntico prévio79,104,141; ausência de deslocamento mandibular lateral durante o fechamento bucal, detectado durante o exame clínico $2,79,104,141,152$; ausência de histórico de trauma facial, ou condições médicas que poderiam ter alterado o crescimento das bases apicais $79,104,136,141,161$ e uma tolerância máxima de $3 \mathrm{~mm}$ de apinhamento nos arcos dentários superior e/ou inferior, desde que simétrico. 

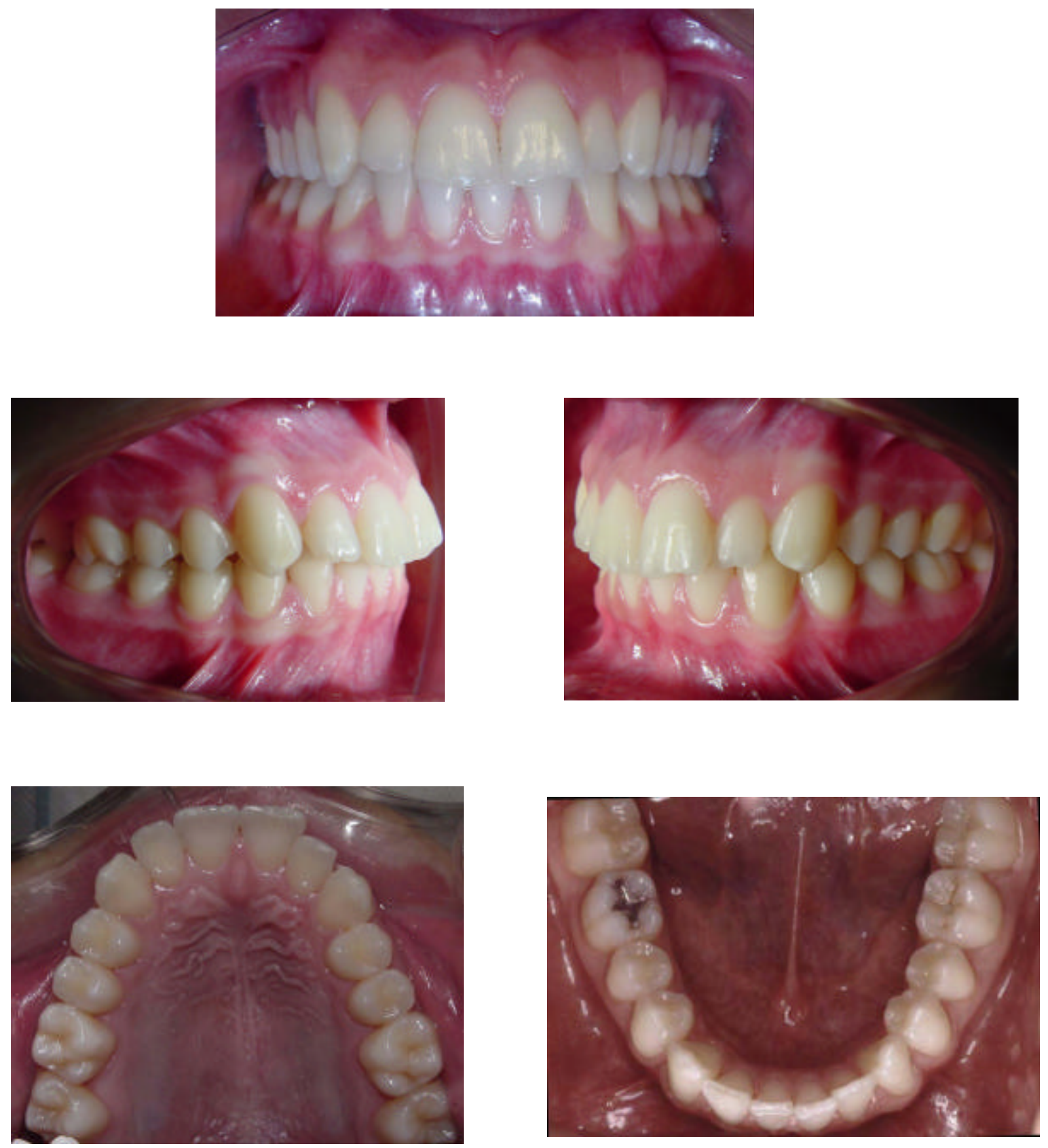

Figura 1 - Caso com Classe II, subdivisão 

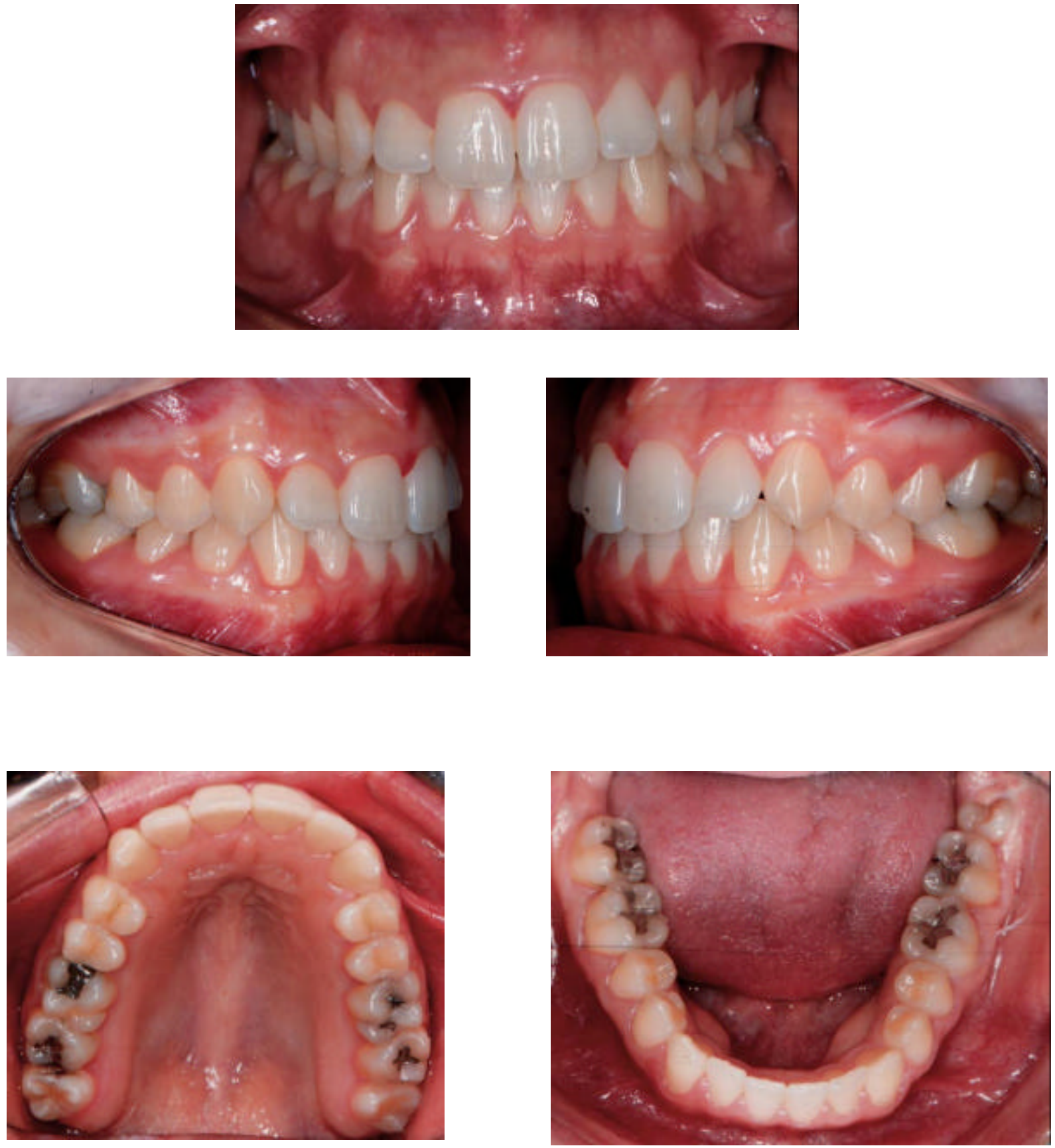

Figura 2-Caso com oclusão normal 


\section{2-Métodos:}

\subsection{1 - Obtenção das fotografias para classificação da Classe II,} subdivisão, quanto aos tipos:

As fotografias dos 30 indivíduos com má oclusão de Classe II, subdivisão inicialmente catalogados foram realizadas com uma câmera fotográfica Nykon F801, já as dos 14 últimos pacientes catalogados foram realizadas com uma câmera fotográfica digital Sony Cyber-shot DSC-F505V. Essas fotografias foram obtidas com o paciente sorrindo, em oclusão habitual, visualizando-se as linhas médias dentárias superiores e inferiores, de forma que uma linha imaginária passando pelo centro da glabela estivesse perpendicular ao solo83(FIGURA 3). A avaliação do desvio das linhas médias dentárias superior e inferior foi realizada de acordo com o método descrito por JERROLD; LOWENSTEIN83.

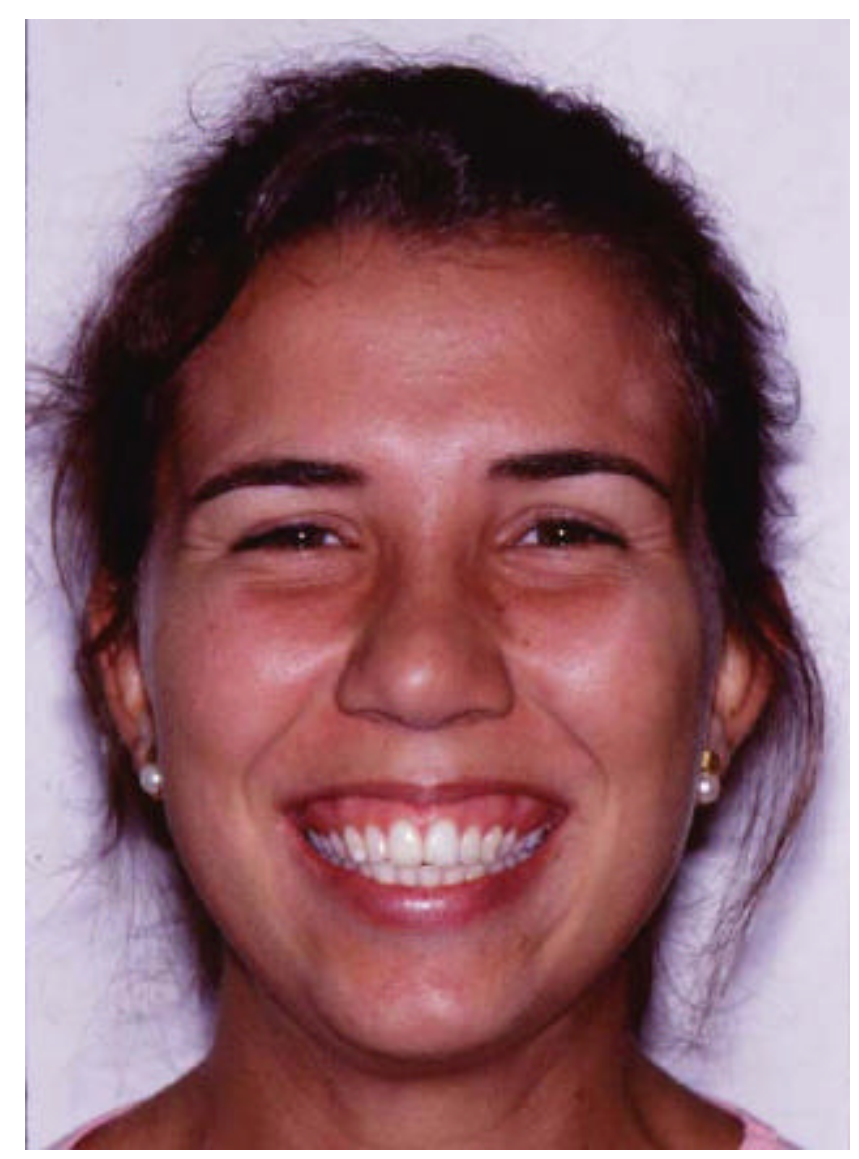

FIGURA - 3 - Análise facial frontal 


\subsection{2 - Obtenção das Radiografias:}

Obtiveram-se duas radiografias de cada indivíduo, uma submentoniana e uma póstero-anterior.

Foram realizados os traçados anatômicos nas radiografias e os pontos demarcados manualmente, em papel de acetato transparente "ultraphan", de 0,07mm de espessura, sobre um negatoscópio, com o auxílio de uma máscara, em uma sala obscurecida. Estes pontos foram posteriormente digitalizados, utilizando-se uma mesa digitalizadora Houston Instrument DT- $11^{1}$, interligada a um microcomputador. Os traçados cefalométricos, assim como as mensurações, foram realizados pelo programa Dentofacial Planner $7.0^{2}$.

\subsubsection{1 - Radiografias submentonianas:}

A técnica de obtenção das radiografias submentonianas baseou-se em metodologias já citadas na literatura54,62,91,92,118,130. Cada jovem foi posicionado sentado em um banco sem encosto de forma que sua cabeça ficasse rotacionada para trás, até que o plano de Frankfurt se apresentasse paralelo ao chassis. O aparelho utilizado para a radiografia foi o TUR D800 ${ }^{3}$, com filme Kodak X-Omat $\mathrm{K}$ (não interfoliado) e com tempo de exposição de 0,125s, a 70kv e 32ma. A distância do ponto focal até as olivas metálicas foi padronizada em $152 \mathrm{~cm}$ e a distância das olivas metálicas até o filme, fixada em $16 \mathrm{~cm}$, fornecendo um fator de magnificação de 9,55\%. Durante a tomada da radiografia, os jovens deveriam manter os dentes em máxima intercuspidação habitual, sob ligeira pressão. Para o traçado das estruturas anatômicas de interesse, demarcação dos pontos e linhas e medição das grandezas cefalométricas, utilizourse a análise de RITUCCI; BURSTONE54,140, com algumas modificações de interesse para esta pesquisa.

\subsubsection{1 - Estruturas Anatômicas (FIGURA 4)}

1- Forame Magno

2- Forames espinhosos

\footnotetext{
${ }^{1}$ Houston Instruments, Austin, Texas, USA.

${ }^{2}$ Dentofacial Planner Software Inc., Toronto, Ontario, Canada.

${ }^{3}$ Dresden, Alemanha (VEB Transformatoren - und Röntgenwerk $>$ Hermann Matern<)
} 
3- Olivas metálicas

4- Mandíbula (incluindo côndilos, ângulos goníacos e processos coronóides)

5- Abóbada craniana posterior

6- Arcos zigomáticos

7- Abóbada craniana anterior

8- Fissuras pterigomaxilares

9- Vômer

10- Primeiros molares superiores

11- Primeiros molares inferiores

12- Incisivos centrais superiores

13- Incisivos centrais inferiores

\subsubsection{2 - Pontos de Referência (FIGURA 5)}

1- O centro medial da oliva metálica direita.

2- O centro medial da oliva metálica esquerda.

3- Gônio direito (GOD) - Ponto médio mediolateralmente na borda posterior do ângulo goníaco direito.

4- Gônio esquerdo (GOE) - Ponto médio mediolateralmente na borda posterior do ângulo goníaco esquerdo.

5- Ponto condilar médio direito (PCMD) - Ponto médio de uma linha que conecta os pontos medial e lateral da cabeça condilar direita.

6- Ponto condilar médio esquerdo (PCME) - Ponto médio de uma linha que conecta os pontos medial e lateral da cabeça condilar esquerda.

7- Ponto condilar medial direito (PCOMD) - O ponto onde uma linha traçada paralelamente ao corpo mandibular toca a porção medial do côndilo direito.

8- Ponto condilar medial esquerdo (PCOME) - O ponto onde uma linha traçada paralelamente ao corpo mandibular toca a porção medial do côndilo esquerdo.

9- Ponto condilar lateral direito (PCLD) - O ponto onde uma linha traçada paralelamente ao corpo mandibular toca a porção lateral do côndilo direito.

10- Ponto condilar lateral esquerdo (PCLE) - O ponto onde uma linha traçada paralelamente ao corpo mandibular toca a porção lateral do côndilo esquerdo. 
11- Distal do primeiro molar inferior direito (DPMID) - O ponto mais distal, alinhado com o sulco mesiodistal central do primeiro molar inferior direito.

12- Distal do primeiro molar inferior esquerdo (DPMIE) - O ponto mais distal, alinhado com o sulco mesiodistal central do primeiro molar inferior esquerdo.

13- Processo coronóide direito $(P C D)$ - O ponto mais anterior, em relação à linha condilar, no processo coronóide direito.

14- Processo coronóide esquerdo (PCE) - O ponto mais anterior, em relação à linha condilar, no processo coronóide esquerdo.

15- Linha média mandibular (LMM) - O ponto mais anterior do corpo da mandíbula. Este é um ponto esquelético.

16- Linha média dentária inferior (LMDI) - O ponto de contato entre as superfícies mesiais das coroas dos incisivos centrais inferiores.

17- Forame espinhoso direito (FED) - $O$ centro geométrico do forame espinhoso direito.

18- Forame espinhoso esquerdo (FEE) - $\mathrm{O}$ centro geométrico do forame espinhoso esquerdo.

19- Linha média dentária superior (LMDS) - O ponto de contato entre as superfícies mesiais das coroas dos incisivos centrais superiores.

20- Vômer anterior (VA) - Intersecção do vômer com uma linha que conecta os pontos angulares direito e esquerdo.

21- Vômer posterior (VP) - Intersecção do vômer com uma linha que conecta os pontos PTM direito e esquerdo.

22- Angulare direito $(A D)^{15,16}$ - O ponto mais anterior, em relação à linha PTM, das opacidades triangulares presentes no ângulo orbital externo, onde as bordas superior e inferior da órbita se encontram e onde o arco zigomático se insere.

23- Angulare esquerdo (AE) $)^{15,16}$ - vide ponto 22.

24- Buccale direito (BD)15,16 - O ponto na superfície interna do arco zigomático direito, onde o mesmo se curva para medial e, em seguida, para trás.

25- Buccale esquerdo $(B E)^{15,16}$ - O ponto na superfície interna do arco zigomático esquerdo, onde o mesmo se curva para medial e, em seguida, para trás. 
26- Fossa craniana média direita (FCMD) - O ponto mais anterior, em relação à linha interespinhosos, na asa menor do osso esfenóide.

27- Fossa craniana média esquerda (FCME) - vide ponto 26.

28- Fissura pterigomaxilar direita (FPMD) - O ponto mais medial e posterior da fissura pterigomaxilar direita.

29- Fissura pterigomaxilar esquerda (FPME) - O ponto mais medial e posterior da fissura pterigomaxilar esquerda.

30- Zygion direito (ZD) - Localizado na intersecção da borda lateral do arco zigomático direito, com uma linha paralela à linha PTM, traçada pela secção de maior largura da distância bizigomática.

31- Zygion esquerdo (ZE) - Localizado na intersecção da borda lateral do arco zigomático esquerdo, com uma linha paralela à linha PTM, traçada pela secção de maior largura da distância bizigomática.

32- Abóbada craniana anterior direita (ACAD)- Ponto onde a borda lateral do crânio é interceptada por uma linha que conecta os pontos zygion direito e esquerdo.

33- Abóbada craniana anterior esquerda (ACAE)- Ponto onde a borda lateral do crânio é interceptada por uma linha que conecta os pontos zygion direito e esquerdo.

34- Básio (Ba) - O ponto mais anterior, em relação à linha interespinhosos, na borda anterior do forame magno.

35- Opístion (Op) - O ponto mais posterior, em relação à linha interespinhosos, na borda posterior do forame magno.

36- Abóbada craniana posterior direita (ACPD) - Ponto onde a borda lateral direita da abóbada craniana é interceptada por uma linha paralela à linha interespinhosos, traçada pela abóbada craniana, em sua secção de maior largura.

37- Abóbada craniana posterior esquerda (ACPE) - Ponto onde a borda lateral esquerda da abóbada craniana é interceptada por uma linha paralela à linha interespinhosos, traçada pela abóbada craniana, em sua secção de maior largura.

38- Contorno médio da mandíbula do lado direito (CMMD) - O ponto mais medial e posterior, no contorno médio do corpo da mandíbula, do lado direito. 
39- Contorno médio da mandíbula do lado esquerdo (CMME) - O ponto mais medial e posterior, no contorno médio do corpo da mandíbula, do lado esquerdo.

40- Ponto médio do eixo transespinhosos (PMETE) - Um ponto médio na linha que une o centro geométrico dos pontos dos forames espinhosos.

41- Ponto perpendicular ao eixo transespinhosos (PERPETE) - Um ponto demarcado perpendicularmente ao eixo transforame espinhoso, à frente do mento, eqüidistante dos forames espinhosos (este e os outros pontos perpendiculares aos eixos das abscissas foram utilizados apenas para possibilitar o traçado dos eixos das ordenadas).

42- Ponto perpendicular ao eixo transcondilar (PERPETC) - Um ponto demarcado perpendicularmente ao eixo transcondilar, à frente do mento, eqüidistante dos pontos médios condilares.

43- Ponto médio do eixo transcondilar (PMETC) - Ponto médio entre os dois pontos condilares médios, no eixo transcondilar.

44- Ponto médio do eixo transpterigomaxilar (PMETPTM)- O ponto médio entre os dois pontos FPM (fissura pterigomaxilar, direita e esquerda), no eixo transpterigomaxilar.

45- Ponto perpendicular ao eixo transpterigomaxilar (PERPETPTM) - Um ponto demarcado perpendicularmente ao eixo transpterigomaxilar, à frente do mento, eqüidistante dos pontos FPM.

46- Ponto médio do eixo transmolar (PMETM)- Ponto médio entre os dois pontos DPMI (distal do primeiro molar inferior direito e esquerdo), no eixo transmolar.

47- Ponto perpendicular ao eixo transmolar (PERPETM) - Um ponto demarcado perpendicularmente ao eixo transmolar, à frente do mento, eqüidistante dos pontos DPMID e DPMIE.

48- Centro da face vestibular do primeiro molar inferior direito (CVPMID).

49- Centro da face vestibular do primeiro molar inferior esquerdo (CVPMIE).

50- Borda mandibular direita (BMD) - Ponto onde a linha perpendicular à face vestibular do primeiro molar inferior direito intercepta a borda mandibular.

51- Borda mandibular esquerda (BME) - Ponto onde a linha perpendicular à face vestibular do primeiro molar inferior esquerdo intercepta a borda mandibular. 
52- Ponto na distal do primeiro molar superior direito (PDMSD) - O ponto mais distal, alinhado com o sulco principal do primeiro molar superior direito.

53- Ponto na distal do primeiro molar superior esquerdo (PDMSE). O ponto mais distal, alinhado com o sulco principal do primeiro molar superior esquerdo.

54- Centro da face vestibular do primeiro molar superior direito (CVPMSD).

55- Centro da face vestibular do primeiro molar superior esquerdo (CVPMSE).

56- Borda mandibular superior direita (BMSD) - Ponto onde a perpendicular à face vestibular do primeiro molar superior direito intercepta a borda mandibular.

57- Borda mandibular superior esquerda (BMSE). Ponto onde a perpendicular à face vestibular do primeiro molar superior esquerdo intercepta a borda mandibular.

58- Ponto médio do eixo transmolar superior (PMETMS)- Ponto médio entre os dois pontos nas distais dos primeiros molares superiores direito e esquerdo no eixo transmolar superior.

59- Ponto perpendicular ao eixo transmolar superior (PERPETMS) - Um ponto demarcado perpendicularmente ao eixo transmolar superior, à frente do mento, eqüidistante dos pontos DPMSD e DPMSE.

\subsubsection{3 - Linhas: (FIGURA 6)}

A- Eixo Transcondilar - ETC - (linha que passa pelos pontos PCMD e PCME, 56)

B- Eixo Transespinhosos - ETE - (linha que passa pelos pontos FED e FEE, 17-18)

C- Eixo Transpterigomaxilar - ETPTM - (linha que passa pelos pontos FPMD e FPME, 28-29)

D- Eixo Transmolares inferiores - ETMI - (linha que passa pelos pontos DPMID e DPMIE, 11-12)

E- Eixo Transmolares superiores - ETMS - (linha que passa pelos pontos DPMSD e DPMSE, 52-53)

F- Eixo Intercondilar - EIC - (linha perpendicular ao eixo Transcondilar, passando pelo ponto médio do mesmo, 42-43) 
G- Eixo Interespinhosos - EIE - (linha perpendicular ao eixo Transespinhosos, passando pelo ponto médio do mesmo, 40-41)

H- Eixo Interpterigomaxilar - EIPTM - (linha perpendicular ao eixo Transpterigomaxilar, passando pelo ponto médio do mesmo, 44-45)

I- Eixo Intermolares inferiores - EIMI - (linha perpendicular ao eixo Transmolar inferior, passando pelo ponto médio do mesmo, 46-47)

J- Eixo Intermolares superiores - EIMS - (linha perpendicular ao eixo Transmolar superior, passando pelo ponto médio do mesmo, 58-59)

\subsubsection{4 - Grandezas Cefalométricas}

O método de RITUCCI; BURSTONE 140 consiste em avaliar a assimetria das estruturas craniodentárias em relação aos diferentes sistemas de coordenadas. Neste estudo foram utilizados os sistemas preconizados por RITUCCI; BURSTONE ${ }^{140}$, com algumas modificações. Os sistemas de coordenadas utilizados foram o sistema de coordenadas mandibulares, do assoalho craniano, zigomaticomaxilar, dentários, e também as medidas angulares entre as abscissas dos sistemas de coordenadas e algumas variáveis adicionais.

Nos sistemas de coordenadas foram estabelecidos dois eixos perpendiculares entre si, para a avaliação do posicionamento ântero-posterior e lateral das estruturas, em relação a esses eixos. Assim, no sistema de coordenadas mandibulares foi estabelecido o eixo transcondilar, passando pelo ponto médio condilar, para a avaliação da simetria do posicionamento ânteroposterior das estruturas mandibulares e o eixo intercondilar, perpendicular, a partir do ponto médio deste, para a avaliação da simetria do posicionamento transversal dessas estruturas. De maneira análoga, foram construídos os eixos transespinhosos e interespinhosos para o sistema de coordenadas do assoalho craniano, os eixos transpterigomaxilar e interpterigomaxilar para 0 sistema de coordenadas zigomaticomaxilares e o eixo intermolares superiores e inferiores para o sistema de coordenadas dentárias. Após a obtenção das grandezas para as variáveis dos lados direito e esquerdo, foi obtida a diferença entre elas. Todas essas variáveis estão descriminadas a seguir.

As radiografias submentonianas e póstero-anteriores do grupo com oclusão normal foram sempre posicionadas com o lado direito do paciente 
coincidente com o lado esquerdo do observador, enquanto que as radiografias do grupo com má oclusão foram posicionadas de forma que o lado com Classe I estivesse sempre do lado esquerdo do observador. Isto foi realizado para que o programa de cefalometria calculasse as diferenças entre medidas bilaterais subtraindo sempre os valores do lado esquerdo, do caso em questão, dos valores do lado direito (nos casos de oclusão normal) e os valores do lado de Classe II, dos do lado da Classe I (nos casos de má oclusão). Os desvios de estruturas centrais, na radiografia submentoniana, foram calculados de forma que se atribuísse um valor positivo se a estrutura estivesse localizada à direita (esquerda do observador) do eixo sagital e um valor negativo, se a estrutura estivesse à esquerda. Na radiografia póstero-anterior adotou-se o critério contrário, por motivos técnicos do programa de cefalometria.

Utilizaram-se valores absolutos para as diferenças entre as medidas dos lados direito e esquerdo e para as distâncias horizontais aos planos de referência médios. Isto eliminou a possibilidade de valores de diferença positivos e negativos se cancelarem no cálculo das médias reais para cada grupo. Entretanto, os valores reais para cada variável foram calculados para elucidar a direção do desvio esquelético ou dentário, quando este estava presente.

O posicionamento das radiografias, da forma anteriormente mencionada, foi realizado para que as leituras dos valores reais, não fossem influenciadas, mas para o cálculo dos valores absolutos, ele poderia ser dispensado.

\subsection{1 - Sistema de coordenadas mandibulares}

\subsection{1 - Ântero-posterior (FIGURA 7):}

1- Gônio direito ao eixo transcondilar (GOD-ETC)

2- Gônio esquerdo ao eixo transcondilar (GOE-ETC)

3- $\quad$ Ponto do processo coronóide direito ao eixo transcondilar (PPCD-ETC)

4- $\quad$ Ponto do processo coronóide esquerdo ao eixo transcondilar (PPCEETC)

5- Ponto distal do primeiro molar inferior direito ao eixo transcondilar (PDMID-ETC) 
6- Ponto distal do primeiro molar inferior esquerdo ao eixo transcondilar (PDMIE-ETC)

7- $\quad$ Ponto distal do primeiro molar superior direito ao eixo transcondilar (PDMSD-ETC)

8- $\quad$ Ponto distal do primeiro molar superior esquerdo ao eixo transcondilar (PDMSE-ETC)

\subsection{2 - Transverso (FIGURA 8):}

9- Gônio direito ao eixo intercondilar (GOD-EIC)

10- Gônio esquerdo ao eixo intercondilar (GOE-EIC)

11- Ponto do processo coronóide direito ao eixo intercondilar (PPCD-EIC)

12- Ponto do processo coronóide esquerdo ao eixo intercondilar (PPCE-EIC)

13- Ponto distal do primeiro molar inferior direito ao eixo intercondilar (PDMID-EIC)

14- Ponto distal do primeiro molar inferior esquerdo ao eixo intercondilar (PDMIE-EIC)

15- Ponto distal do primeiro molar superior direito ao eixo intercondilar (PDMSD-EIC)

16- Ponto distal do primeiro molar superior esquerdo ao eixo intercondilar. (PDMSE-EIC)

17- Linha média mandibular ao eixo intercondilar (LMM-EIC)

18- Linha média dentária inferior ao eixo intercondilar (LMDFEIC)

19- Linha média dentária superior ao eixo intercondilar (LMDS-EIC)

\subsection{2 - Sistema de coordenadas do assoalho craniano}

\subsection{1 - Ântero-posterior (FIGURA 9):}

20- Ponto condilar médio direito ao eixo transespinhosos (PCMD-ETE).

21- Ponto condilar médio esquerdo ao eixo transespinhosos (PCME-ETE).

22- Gônio direito ao eixo transespinhosos (GOD-ETE).

23- Gônio esquerdo ao eixo transespinhosos (GOE-ETE).

24- Ponto no processo coronóide direito ao eixo transespinhosos (PPCDETE). 
25- Ponto no processo coronóide esquerdo ao eixo transespinhosos (PPCEETE).

26- Ponto na distal do primeiro molar inferior direito ao eixo transespinhosos (PDMID-ETE).

27- Ponto na distal do primeiro molar inferior esquerdo ao eixo transespinhosos (PDMIE-ETE).

28- Ponto na distal do primeiro molar superior direito ao eixo transespinhosos (PDMSD-ETE)

29- Ponto na distal do primeiro molar superior esquerdo ao eixo transespinhosos (PDMSE-ETE)

30- Abóbada craniana posterior direita ao eixo transespinhosos (ACPD-ETE)

31- Abóbada craniana posterior esquerda ao eixo transespinhosos (ACPEETE)

32- Fossa craniana média direita ao eixo transespinhosos (FCMD-ETE)

33- Fossa craniana média esquerda ao eixo transespinhosos (FCME-ETE)

\subsection{2 - Transverso (FIGURA 10):}

34- Ponto condilar médio direito ao eixo interespinhosos (PCMD-EIE)

35- Ponto condilar médio esquerdo ao eixo interespinhosos (PCME-EIE)

36- Gônio direito ao eixo interespinhosos (GOD-EIE)

37- Gônio esquerdo ao eixo interespinhosos (GOE-EIE)

38- Ponto no processo coronóide direito ao eixo interespinhosos (PPCDEIE)

39- Ponto no processo coronóide esquerdo ao eixo interespinhosos (PPCEEIE)

40- Ponto distal do primeiro molar inferior direito ao eixo interespinhosos (PDMID-EIE)

41- Ponto distal do primeiro molar inferior esquerdo ao eixo interespinhosos (PDMIE-EIE)

42- Ponto distal do primeiro molar superior direito ao eixo interespinhosos (PDMSD-EIE)

43- Ponto distal do primeiro molar superior esquerdo ao eixo interespinhosos (PDMSE-EIE)

44- Linha média mandibular ao eixo interespinhosos (LMM-EIE) 
45- Linha média dentária inferior ao eixo interespinhosos (LMDIEIE)

46- Linha média dentária superior ao eixo interespinhosos (LMDS-EIE)

47- Abóbada craniana posterior direita ao eixo interespinhosos (ACPD-EIE)

48- Abóbada craniana posterior esquerda ao eixo interespinhosos (ACPEEIE)

49- Fossa craniana média direita ao eixo interespinhosos (FCMD-EIE)

50- Fossa craniana média esquerda ao eixo interespinhosos (FCME-EIE)

51- Básio ao eixo interespinhosos (Ba-EIE).

52- Opístion ao eixo interespinhosos (Op-EIE)

\subsection{3 - Sistema de coordenadas do complexo zigomaticomaxilar}

\subsection{1 - Ântero-posterior (FIGURA 11):}

53- Buccale direito ao eixo transpterigomaxilar (BCD-ETPTM)

54- Buccale esquerdo ao eixo transpterigomaxilar (BCE-ETPTM)

55- Zygion direito ao eixo transpterigomaxilar (ZD-ETPTM)

56- Zygion esquerdo ao eixo transpterigomaxilar (ZE-ETPTM)

57- Abóbada craniana anterior direita ao eixo transpterigomaxilar (ACADETPTM)

58- Abóbada craniana anterior esquerda ao eixo transpterigomaxilar (ACAEETPTM)

59- Angulare direito ao eixo transpterigomaxilar (AD-ETPTM)

60- Angulare esquerdo ao eixo transpterigomaxilar (AE-ETPTM)

61- Ponto distal do primeiro molar inferior direito ao eixo transpterigomaxilar (PDMID-ETPTM)

62- Ponto distal do primeiro molar inferior esquerdo ao eixo transpterigomaxilar (PDMIE-ETPTM)

63- Ponto distal do primeiro molar superior direito ao eixo transpterigomaxilar (PDMSD-ETPTM)

64- Ponto distal do primeiro molar superior esquerdo ao eixo transpterigomaxilar (PDMSE-ETPTM)

\subsection{2 - Transverso (FIGURA 12):}

65- Buccale direito ao eixo interpterigomaxilar (BCD-EIPTM) 
66- Buccale esquerdo ao eixo interpterigomaxilar (BCE-EIPTM)

67- Zygion direito ao eixo interpterigomaxilar (ZD-EIPTM)

68- Zygion esquerdo ao eixo interpterigomaxilar (ZE-EIPTM)

69- Abóbada craniana anterior direita ao eixo interpterigomaxilar (ACADEIPTM)

70- Abóbada craniana anterior esquerda ao eixo interpterigomaxilar (ACAEEIPTM)

71- Angulare direito ao eixo interpterigomaxilar (AD-EIPTM)

72- Angulare esquerdo ao eixo interpterigomaxilar (AE-EIPTM)

73- Ponto vômer anterior ao eixo interpterigomaxilar (PVA-EIPTM)

74- Ponto vômer posterior ao eixo interpterigomaxilar (PVP-EIPTM)

75- Ponto distal do primeiro molar inferior direito ao eixo interpterigomaxilar (PDMID-EIPTM)

76- Ponto distal do primeiro molar inferior esquerdo ao eixo interpterigomaxilar (PDMIE -EIPTM)

77- Ponto distal do primeiro molar superior direito ao eixo interpterigomaxilar (PDMSD-EIPTM)

78- Ponto distal do primeiro molar superior esquerdo ao eixo interpterigomaxilar (PDMSE-EIPTM)

79- Linha média dentária superior ao eixo interpterigomaxilar (LMDS-EIPTM)

80- Linha média mandibular ao eixo interpterigomaxilar (LMM-EIPTM)

81- Linha média dentária inferior ao eixo interpterigomaxilar (LMDFEIPTM)

\subsection{4 - Sistema de coordenadas dentárias (FIGURA 13):}

\subsection{1 - Ântero-posterior:}

82- Ponto na distal do primeiro molar inferior direito ao ponto condilar médio direito (PDMID -PCMD)

83- Ponto na distal do primeiro molar inferior esquerdo ao ponto condilar médio esquerdo (PDMIE-PCME)

84- Ponto na distal do primeiro molar superior direito ao ponto condilar médio direito (PDMSD-PCMD)

85- Ponto na distal do primeiro molar superior esquerdo ao ponto condilar médio esquerdo (PDMSE-PCME) 


\subsection{2 - Transverso:}

86- Linha média dentária inferior ao eixo intermolares inferiores (LMDFEIM)

87- Linha média mandibular ao eixo intermolares inferiores (LMM-EIM)

88- Linha média dentária superior ao eixo intermolares inferiores (LMDSEIM)

89- Linha média dentária inferior ao eixo intermolares superiores (LMDF EIMS)

90- Linha média dentária superior ao eixo intermolares superiores (LMDSEIMS)

91- Linha média mandibular ao eixo intermolares superiores (LMM-EIMS)

\subsection{5 - Medidas angulares entre as abscissas dos sistemas de coordenadas (FIGURA 14):}

92- Ângulo entre os eixos interespinhosos e intercondilar (EIE.EIC)

93- Ângulo entre o eixo transespinhosos e o eixo transcondilar (ETE.ETC)

94- Ângulo entre o eixo transpterigomaxilar e o eixo transcondilar (ETPTM.ETC)

95- Ângulo entre o eixo transpterigomaxilar e o eixo transespinhosos (ETPTM.ETE)

96- Ângulo entre o eixo transmolar inferior e o eixo transespinhosos (ETMETE)

97- Ângulo entre o eixo transmolar inferior e o eixo transcondilar (ETM-ETC)

98- Ângulo entre o eixo transmolar inferior e o eixo transpterigomaxilar (ETMI-ETPTM)

99- Ângulo entre o eixo transmolar superior e o eixo transespinhosos (ETMS-ETE)

100- Ângulo entre o eixo transmolar superior e o eixo transcondilar (ETMSETC)

101- Ângulo entre o eixo transmolar superior e o eixo transpterigomaxilar (ETMS-ETPTM)

\subsubsection{6 - Variáveis adic ionais (FIGURA 15):}

102- Distância do ponto condilar médio direito à linha média mandibular (PCMD-LMM) 
103- Distância do ponto condilar médio esquerdo à linha média mandibular (PCME-LMM)

104- Ponto condilar médio direito ao contorno médio da mandíbula direita (PCMD-CMMD)

105- Ponto condilar médio esquerdo ao contorno médio da mandíbula esquerda (PCME-CMME).

106- Posição lateral do primeiro molar inferior direito (POSMD)

107- Posição lateral do primeiro molar inferior esquerdo (POSME)

108- Posição lateral do primeiro molar superior direito (POSMSD)

109- Posição lateral do primeiro molar superior esquerdo (POSMSE)

\subsection{7 - Diferenças entre medidas bilaterais}

\subsection{1 - Coordenadas mandibulares}

\subsection{1.1 - Ântero-posterior:}

110- Diferença de GO ao ETC (1-2)

111- Diferença de PPC ao ETC (3-4)

112- Diferença de PDMI ao ETC (5-6)

113- Diferença PDMS ao ETC (7-8)

\subsection{1.2 - Transverso:}

114- Diferença de GO ao EIC (9-10)

115- Diferença de PPC ao EIC (11-12)

116- Diferença de PDMI ao EIC (13-14)

117- Diferença PDMS ao EIC (15-16)

\subsubsection{4.}

\subsection{2.1 - Ântero-posterior:}

118- Diferença de PCM ao ETE (20-21)

119- Diferença de GO ao ETE (22-23)

120- Diferença de PPC ao ETE (24-25)

121- Diferença de PDMI ao ETE (26-27) 
122- Diferença PDMS ao ETE (28-29)

123- Diferença de ACP ao ETE (30-31)

124- Diferença de FCM ao ETE (32-33)

\subsection{2.2 - Transverso:}

125- Diferença de PCM ao EIE (34-35)

126- Diferença de GO ao EIE (36-37)

127- Diferença de PPC ao EIE (38-39)

128- Diferença de PDMI ao EIE (40-41)

129- Diferença PDMS ao EIE (42-43)

130- Diferença de ACP ao EIE (47-48)

131- Diferença de FCM ao EIE (49-50)

\subsection{3 - Complexo zigomaticomaxilar}

\subsection{3.1 - Ântero-posterior:}

132- Diferença de BC ao ETPTM (53-54)

133- Diferença de PZ ao ETPTM (55-56)

134- Diferença de ACA ao ETPTM (57-58)

135- Diferença de A ao ETPTM (59-60)

136- Diferença de PDMI ao ETPTM (61-62)

137- Diferença de PDMS ao ETPTM (63-64)

\subsection{3.2 - Transverso:}

138- Diferença de BC ao EIPTM (65-66)

139- Diferença de ZP ao EIPTM (67-68)

140- Diferença de ACA ao EIPTM (69-70)

141- Diferença de A ao EIPTM (71-72)

142- Diferença de PDMI ao EIPTM (75-76)

143- Diferença de PDMS ao EIPTM (77-78)

\subsection{4 - Dentárias:}

4.2.2.1.4.7.4.1 - Ântero-posterior: 
144- Diferença de PDMI ao PCM (82-83)

145- Diferença de PDMS ao PCM (84-85)

\subsection{5 - Adicionais:}

146- Diferença entre PCM-LMM (102-103)

147- Diferença entre PCM-CMM (104-105)

148- Diferença de POSM (106-107)

149- Diferença de POSMS (108-109) 


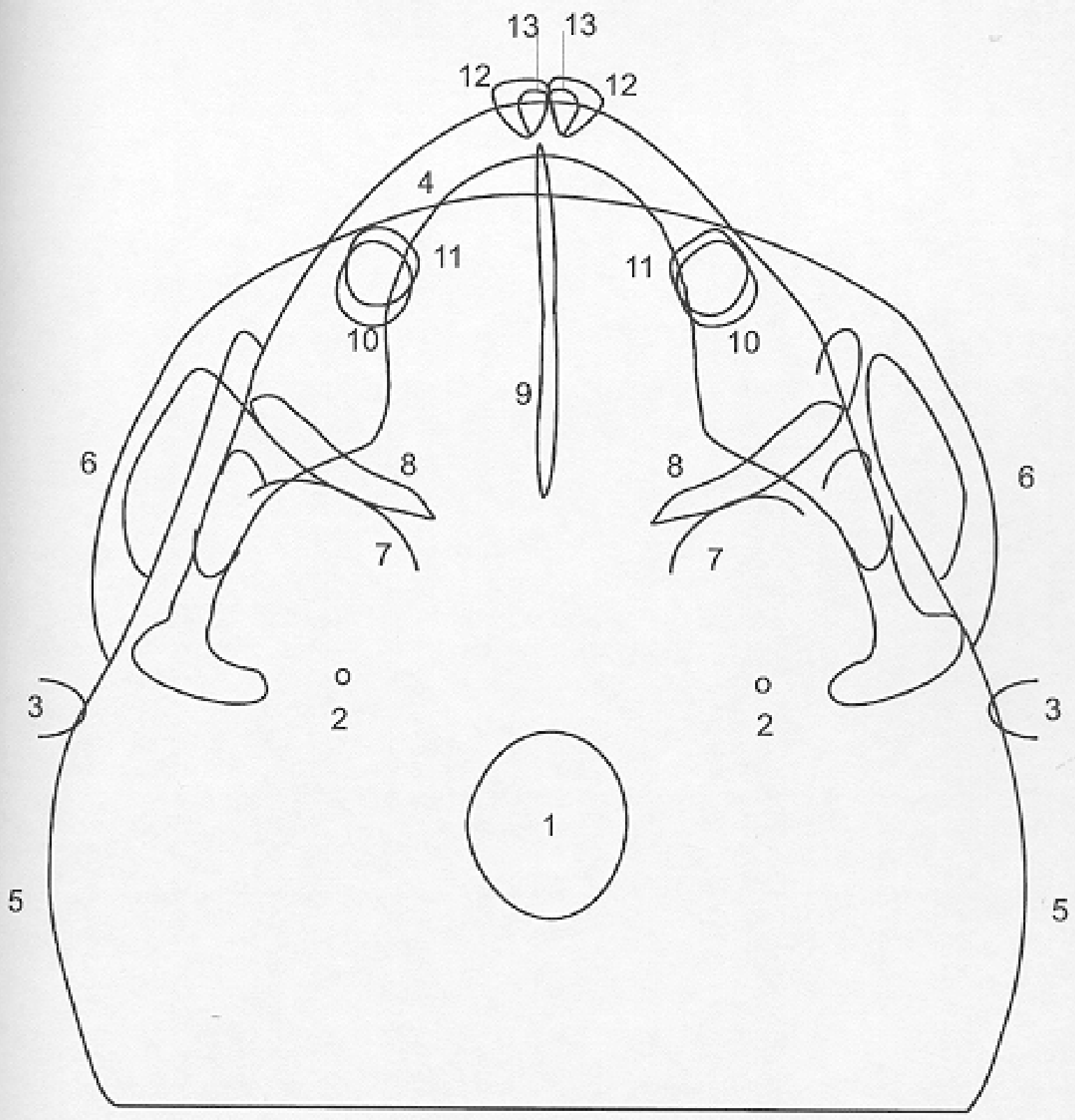

FIGURA - 4 - Estruturas anatômicas da radiografia submentoniana* 


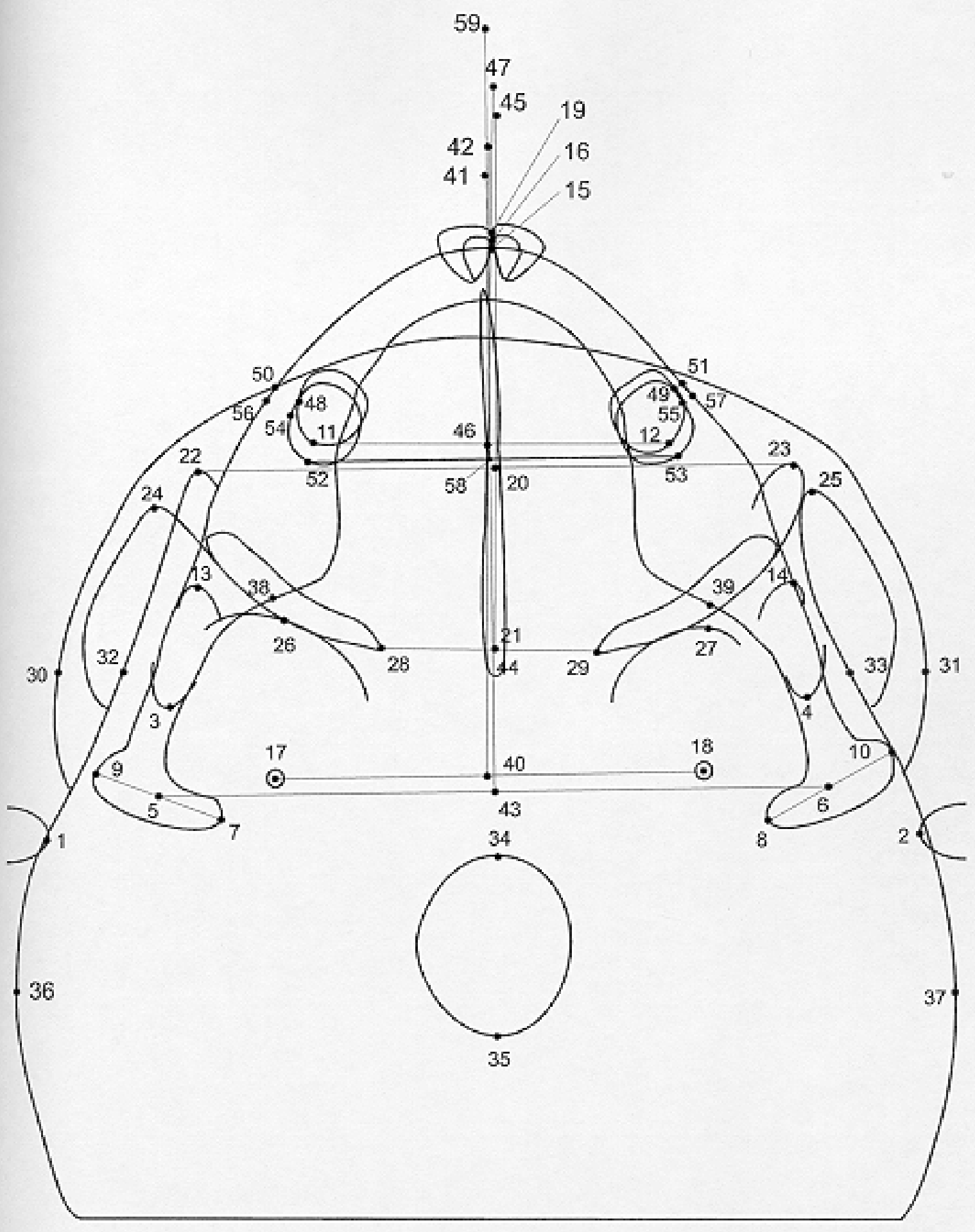

FIGURA - 5 - Pontos da radiografia submentoniana"

'FONTE: Figura reproduzida da pesquisa de JANSON 79 . 


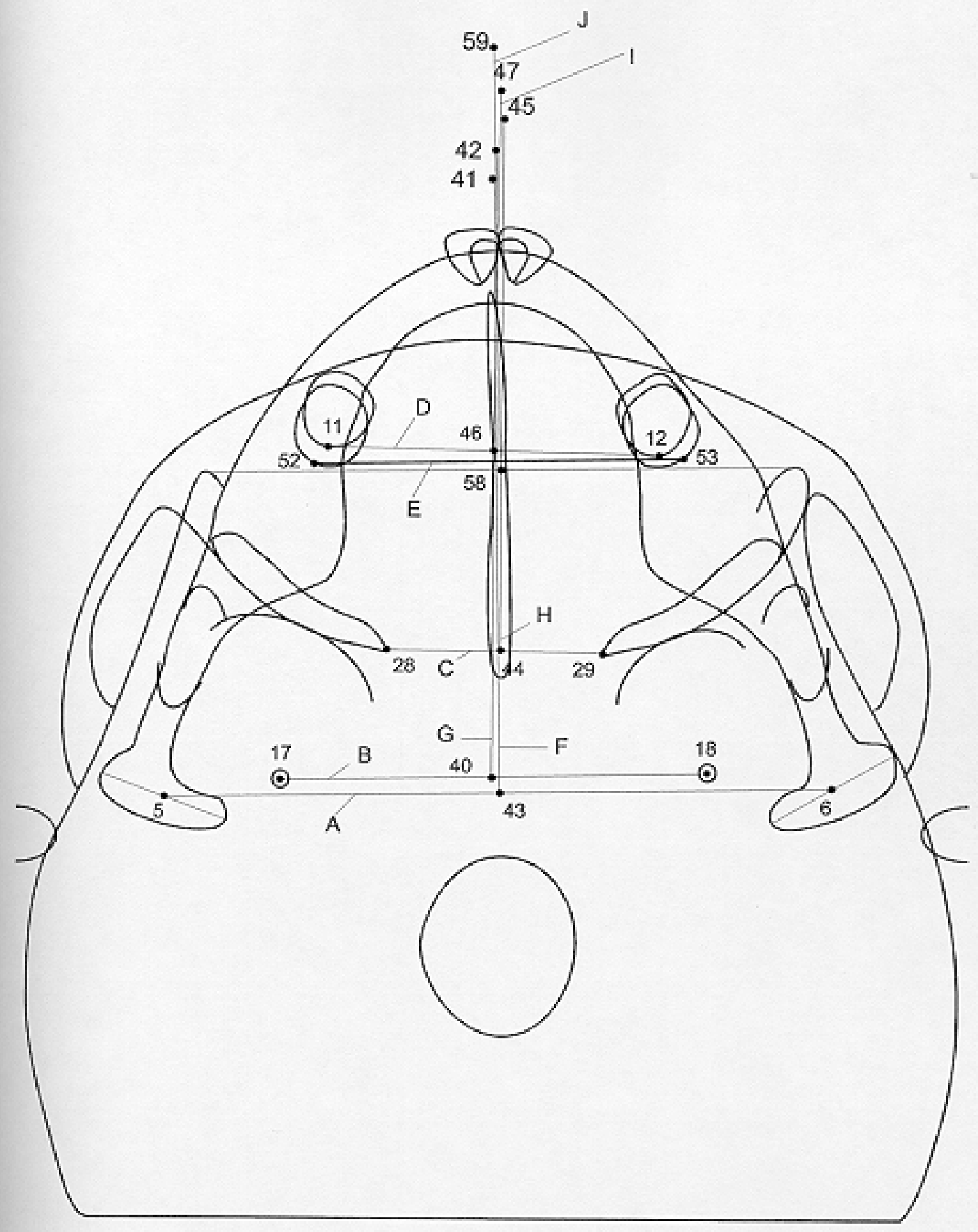

FIGURA - 6 - Linhas da radiografia submentoniana*

\section{'FONTE: Figura reproduzida da pesquisa de JANSON 79 .}




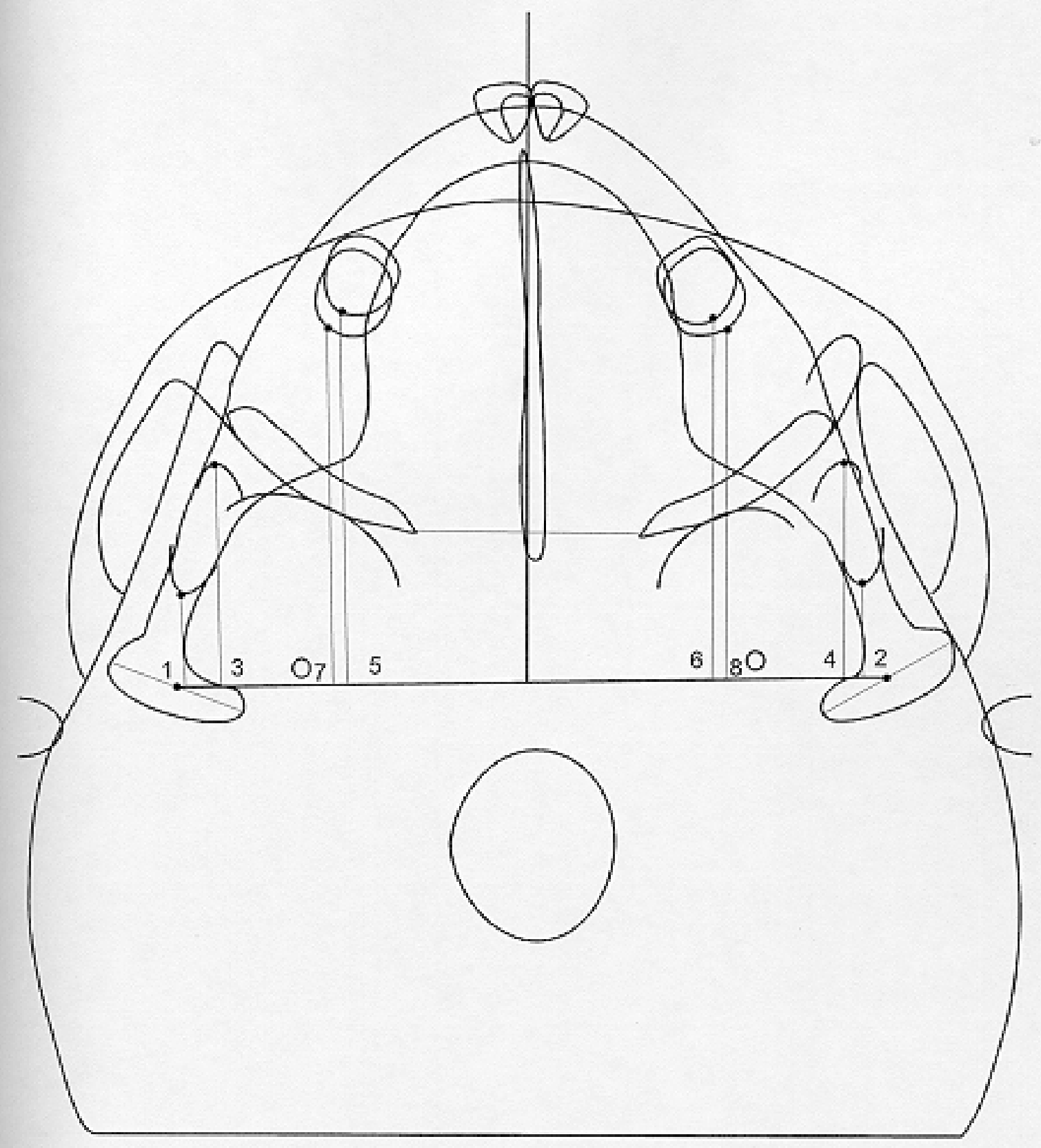

FIGURA - 7 - Grandezas cefalométricas da radiografia submentoniana Sistema de Coordenadas Mandibulares - Ântero-Posterior* 


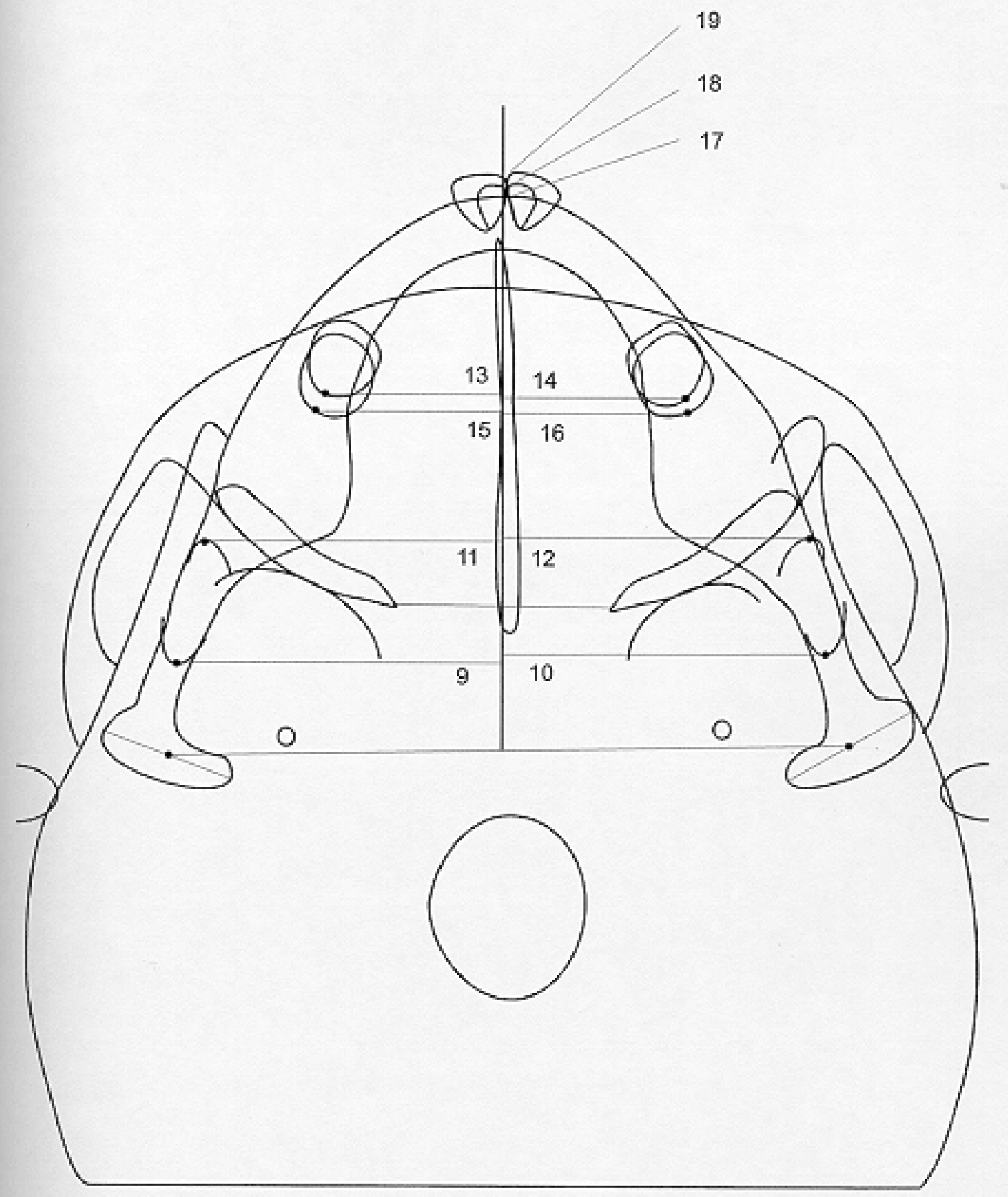

FIGURA - 8 - Grandezas cefalométricas da radiografia submentoniana Sistema de Coordenadas Mandibulares - Transverso* 


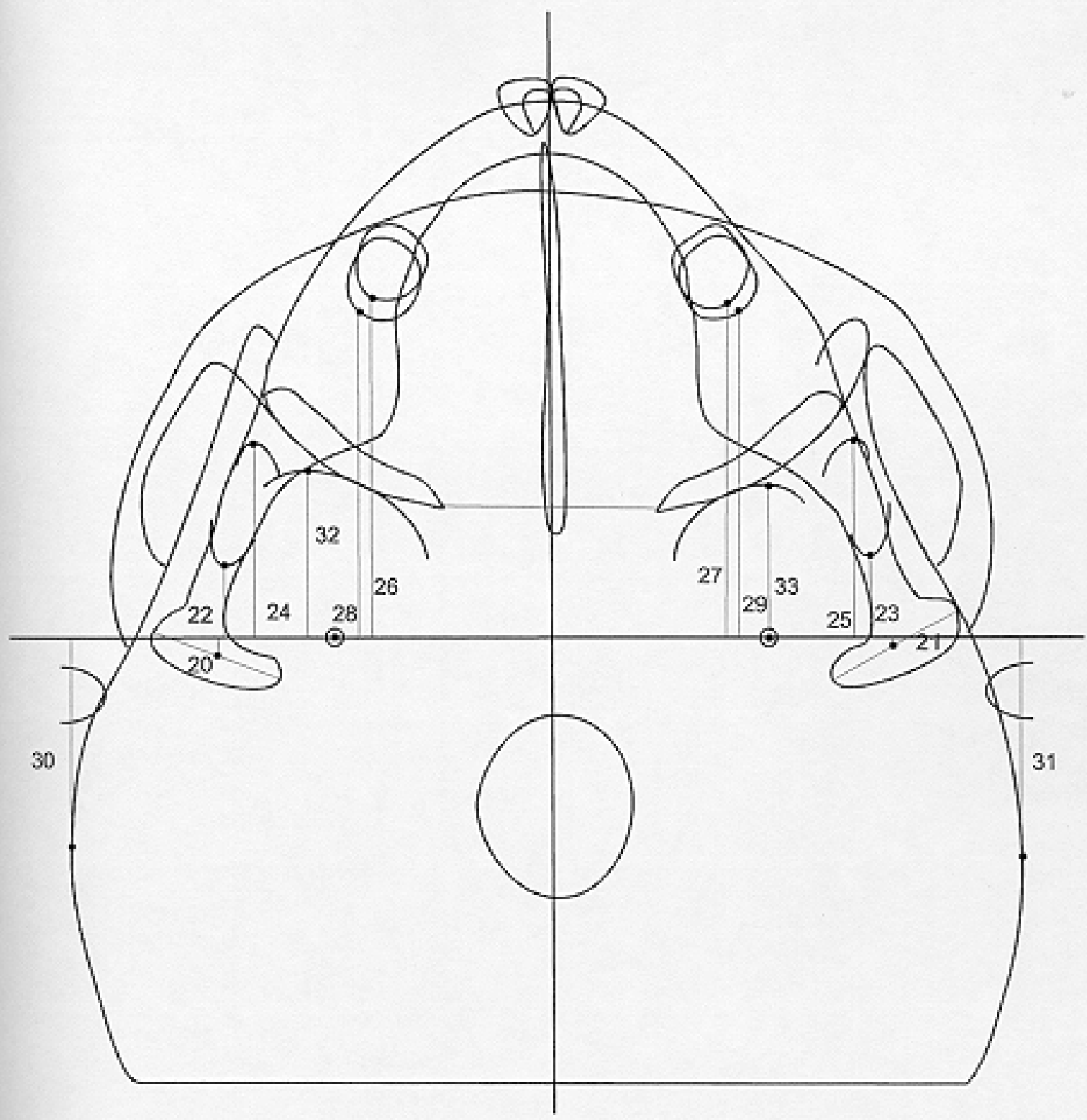

FIGURA - 9 - Grandezas cefalométricas da radiografia submentoniana Sistema de Coordenadas do Assoalho Craniano - ÂnteroPosterior 


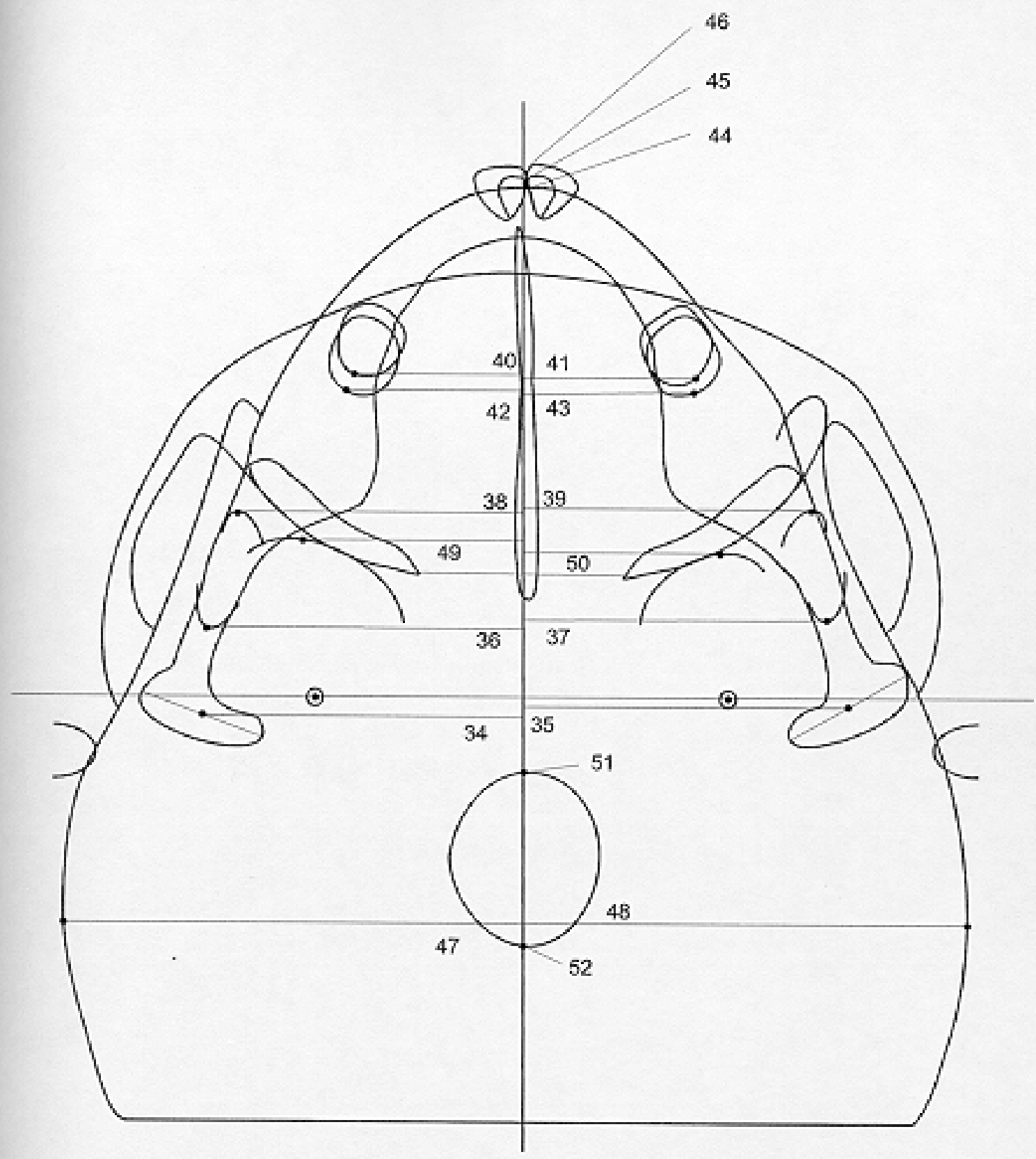

FIGURA - 10 - Grandezas cefalométricas da radiografia submentoniana Sistema de Coordenadas do Assoalho Craniano -Transverso* 


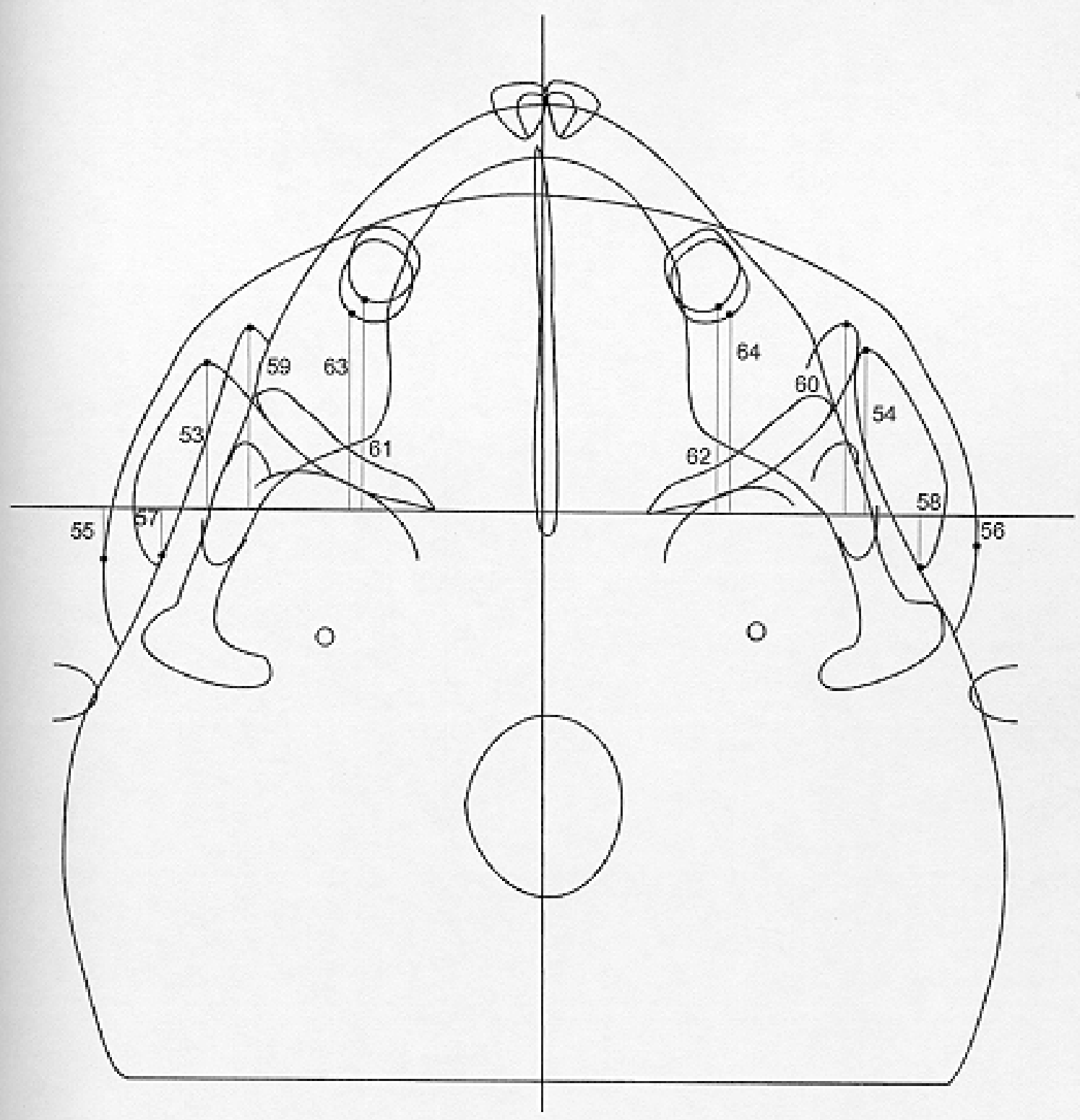

FIGURA - 11 - Grandezas cefalométricas da radiografia submentoniana Sistema de Coordenadas do Complexo Zigomaticomaxilar Ântero-Posterior ${ }^{*}$ 


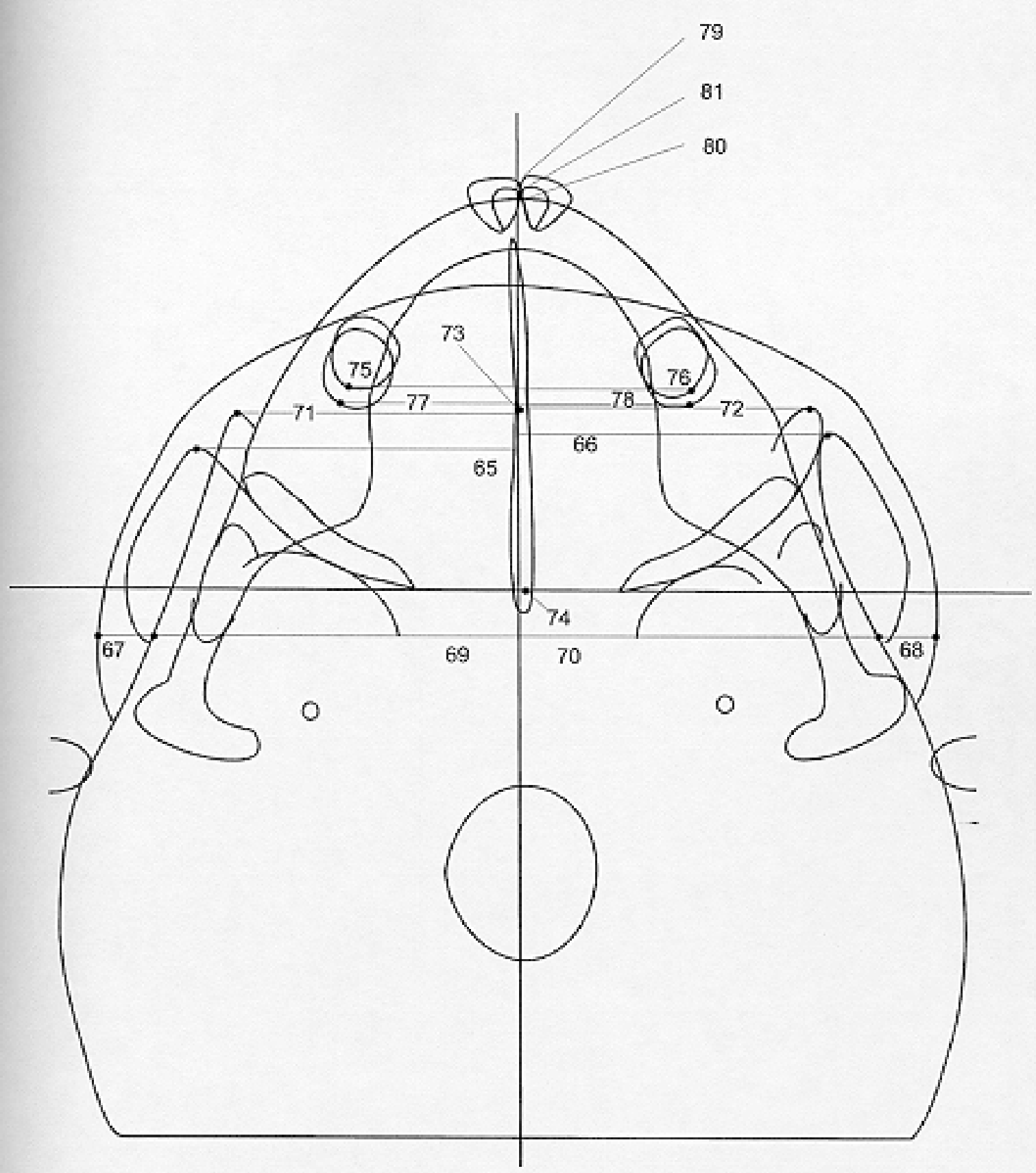

FIGURA - 12 - Grandezas cefalométricas da radiografia submentoniana Sistema de Coordenadas do Complexo Zigomaticomaxilar Transverso ${ }^{*}$ 


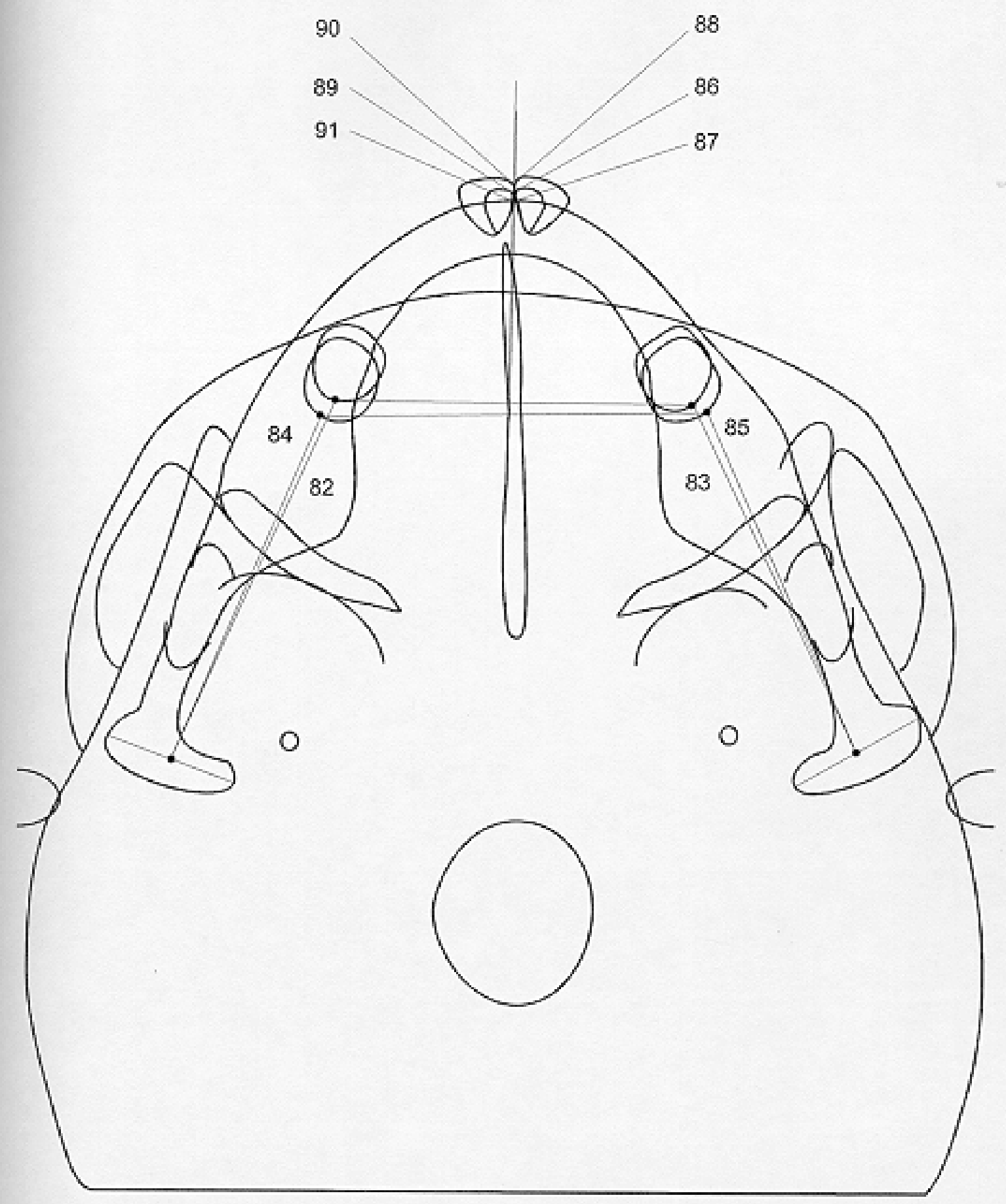

FIGURA - 13 - Grandezas cefalométricas da radiografia submentoniana Sistema de Coordenadas Dentárias - Ântero-posterior e Transverso* 


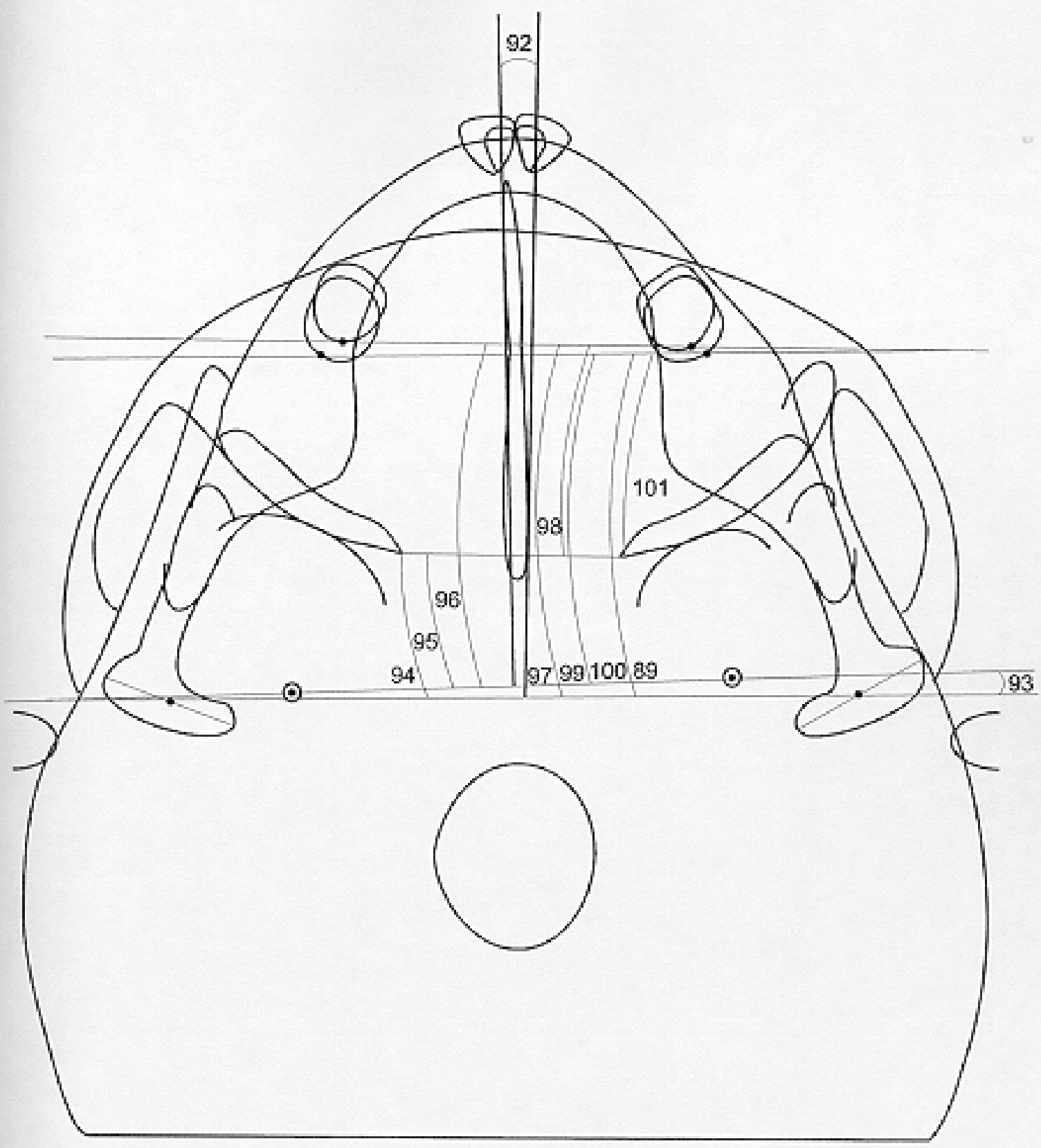

FIGURA -14 - Grandezas cefalométricas da radiografia submentoniana Medidas Angulares entre as abscissas dos Sistemas de Coordenadas* 


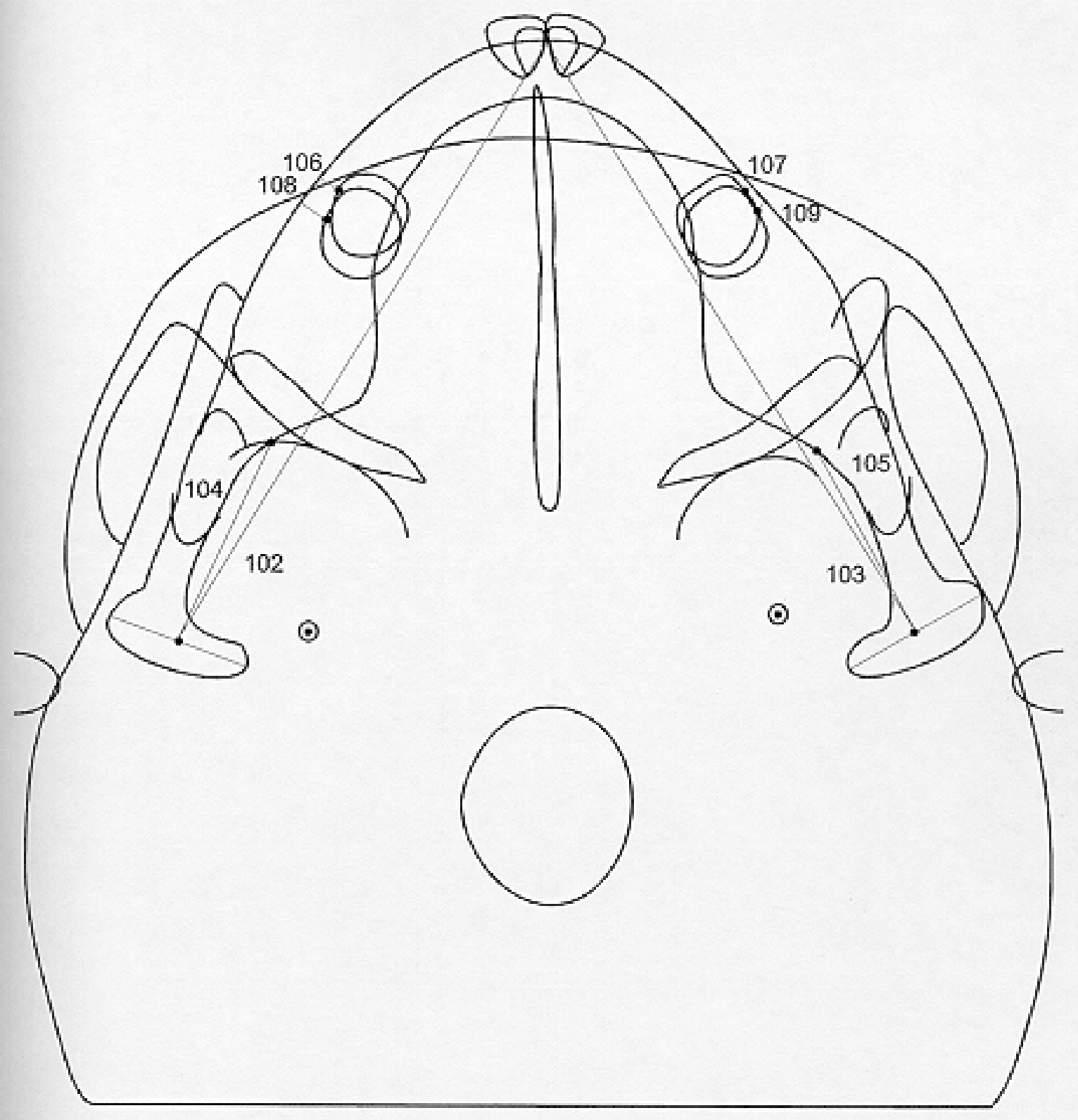

FIGURA - 15 - Grandezas cefalométricas da radiografia submentoniana Variáveis Adicionais* 


\subsubsection{2 - Radiografias póstero-anteriores:}

As radiografias póstero-anteriores dos novos pacientes foram obtidas utilizando-se a seguinte técnica: cada jovem foi posicionado no cefalostato, com a testa e o nariz tocando levemente o chassis 67 . O aparelho utilizado para essas radiografias foi o ROENTAX $10090^{4}$, com filme Kodak X-Omat K (não interfoliado) e tempo de exposição de 1s, a 90kVp e 25ma. A distância do ponto focal até às olivas metálicas foi padronizada em $152 \mathrm{~cm}$ e a distância das olivas metálicas até o filme foi fixada em $16 \mathrm{~cm}$, o que fornecia um fator de magnificação de $8,9 \%$. Durante a tomada das radiografias, os jovens mantiveram os dentes em máxima intercuspidação habitua91,112,118,149,152.

A delimitação das estruturas anatômicas, a demarcação dos pontos e linhas e a obtenção das grandezas cefalométricas foram realizadas nas radiografias, de acordo com GRUMMONS; VAN DE COPPELLO64.

\subsubsection{1 - Estruturas anatômicas (FIGURA 16):}

Para as estruturas bilaterais os números referem-se às estruturas enumeradas e às suas homólogas, do lado oposto.

1- Órbitas

2- Contornos da cavidade nasal

3- Crista galli

4- Arcos zigomáticos

5- Contorno mandibular de um côndilo a outro

6- Contornos maxilares direito e esquerdo

7- Aspectos laterais do osso frontal

8- Aspectos laterais dos ossos zigomáticos

9- Incisivos centrais superiores

10- Incisivos centrais inferiores

11- Primeiros molares superiores

12- Primeiros molares inferiores

\footnotetext{
${ }^{4}$ EMIC (Eletro Medicina Indústria e Comércio LTDA - R. Paulo Franco, 195, São Paulo - SP Brasil - Fone: 11 - 83211131)
} 


\subsubsection{2 - Pontos de referência (FIGURA 17):}

1- Ponto mais superior no contorno da margem da órbita direita, localizado à meia distância, entre as margens média e lateral.

2- Ponto localizado na borda lateral da órbita direita, na porção interna da sutura fronto-zigomática.

3- Ponto mais inferior do contorno da órbita direita, localizado aproximadamente à meia distância, entre as margens média e lateral.

4- Ponto mais medial do contorno da órbita direita, localizado aproximadamente à meia distância, entre as margens superior e inferior.

5- Ponto mais superior do contorno da órbita esquerda, localizado aproximadamente à meia distância, entre as margens média e lateral.

6- Ponto mais medial do contorno da órbita esquerda, localizado aproximadamente à meia distância, entre as margens superior e inferior.

7- Ponto mais inferior do contorno da órbita esquerda, localizado aproximadamente à meia distância, entre as margens medial e lateral.

8- Ponto localizado na borda lateral da órbita esquerda, na porção interna da sutura fronto-zigomática.

9- Ponto mais superior do contorno do orifício nasal.

10- Ponto mais lateral do contorno do orifício nasal, na região da abertura piriforme direita.

11 - Ponto localizado na intersecção do septo nasal com o assoalho do nariz.

12- Ponto mais lateral do contorno do orifício nasal, na região da abertura piriforme esquerda.

13- Ponto de referência súpero-lateral direito: ponto localizado na porção lateral da sutura fronto-zigomática direita, ou na intersecção da asa maior direita do esfenóide e da margem orbitária.

14- Ponto na margem lateral do arco zigomático direito, centrado verticalmente.

15- Ponto localizado na profundidade da concavidade do contorno lateral do maxilar direito, na junção da maxila e do osso zigomático.

16- Ponto de referência súpero-lateral esquerdo: ponto localizado na porção lateral da sutura fronto-zigomática esquerda, ou na intersecção da asa maior esquerda do esfenóide e da margem orbitária.

17- Ponto na margem lateral do arco zigomático esquerdo, centrado verticalmente. 
18- Ponto localizado na profundidade da concavidade do contorno lateral do maxilar esquerdo, na junção da maxila e do osso zigomático.

19- Ponto localizado numa perpendicular à superfície oclusal do primeiro molar superior direito, através da cúspide vestibular, na altura da raiz vestibular (verticalmente).

20- Ponta de cúspide vestibular do primeiro molar superior direito.

21- Ápice radicular do incisivo central superior direito.

22- Ponto localizado no meio da borda incisal do incisivo central superior direito.

23- Ponto localizado apicalmente entre as raízes dos incisivos centrais superiores, a aproximadamente $2 / 3$ do comprimento radicular.

24- Ápice radicular do incisivo central superior esquerdo.

25- Ponto localizado no meio da borda incisal do incisivo central superior esquerdo.

26- Ponto localizado numa perpendicular à superfície oclusal do primeiro molar superior esquerdo, através da cúspide vestibular, na altura da raiz vestibular.

27- Ponta de cúspide vestibular do primeiro molar superior esquerdo.

28- Ponta de cúspide vestibular do primeiro molar inferior direito.

29- Ponto localizado no ápice radicular, através de uma perpendicular traçada à superfície oclusal do primeiro molar inferior direito, a partir da cúspide vestibular.

30- Ponto centrado na borda incisal do incisivo central inferior direito.

31- Ápice radicular do incisivo central inferior direito.

32- Ponto localizado apicalmente entre as raízes dos incisivos centrais inferiores, a aproximadamente $2 / 3$ do comprimento da raiz.

33- Ponto centrado na borda incisal do incisivo central inferior esquerdo.

34- Ápice radicular do incisivo central inferior esquerdo.

35- Ponta de cúspide vestibular do primeiro molar inferior esquerdo.

36- Ponto localizado no ápice radicular do primeiro molar inferior esquerdo, através de uma perpendicular traçada na sua superfície oclusal, a partir da cúspide vestibular.

37- Ponto centrado na superfície superior da cabeça do côndilo direito.

38- Ponto localizado na borda lateral da cabeça do côndilo direito.

39- Ponto localizado na borda lateral do ramo mandibular direito, localizado 
aproximadamente à meia distância, entre a cabeça do côndilo e o ângulo goníaco.

40- Ponto localizado na junção da borda lateral do ramo mandibular direito com o início da convexidade do ângulo goníaco direito.

41- Ponto localizado no ângulo goníaco direito da mandíbula.

42- Ponto localizado na chanfradura antegoniana direita.

43 Ponto localizado na superfície inferior do corpo mandibular direito, entre o ângulo goníaco e a sínfise.

44- Ponto localizado na superfície inferior do corpo mandibular direito, representando o limite lateral direito da concavidade da sínfise (se existir). 45- Ponto mentoniano: o ponto mais inferior na borda da mandíbula, na sínfise. 46- Ponto localizado na superfície inferior do corpo mandibular esquerdo, representado o limite lateral esquerdo da concavidade da sínfise (se existir). 47- Ponto na superfície inferior do corpo mandibular esquerdo, à meia distância entre o ângulo goníaco e a sínfise.

48- Ponto localizado na chanfradura antegoniana esquerda.

49- Ponto localizado no ângulo goníaco esquerdo da mandíbula.

50- Ponto localizado na junção da borda lateral do ramo mandibular esquerdo, com o início da convexidade do ângulo goníaco esquerdo.

51- Ponto na borda lateral do ramo mandibular esquerdo, aproximadamente à meia distância entre a cabeça do côndilo e o ângulo goníaco.

52- Ponto localizado na borda lateral da cabeça do côndilo esquerdo.

53- Ponto centrado na superfície superior da cabeça do côndilo esquerdo.

54- Ponto mais superior da Crista galli, idealmente no meio do osso.

55- Espinha nasal anterior.

56- Ponto médio de intercuspidação das pontas de cúspides dos primeiros molares superior e inferior, do lado direito (construído).

57- Ponto médio de intercuspidação das pontas de cúspides dos primeiros molares superior e inferior, do lado esquerdo (construído).

58- Ponto médio entre os incisivos superiores (construído).

59- Ponto médio entre. os incisivos inferiores (construído).

\subsubsection{3 - Linhas e Planos (FIGURA 18):}

A- Plano Z (linha) - formado pela conexão dos pontos 2 e 8. 
B- Linha X66- linha perpendicular ao plano Z, passando pela Crista galli.

C- Plano oclusal - plano formado entre os pontos médios de intercuspidação das pontas de cúspides dos primeiros molares superior e inferior, de cada lado, respectivamente (pontos 56 e 57, construídos).

D- Plano antegoniano - plano formado entre os pontos 42 e 48 (chanfradura antegoniana).

E- Linha do ramo mandibular direito (formada pelos pontos 37 e 42).

F- Linha do ramo mandibular esquerdo (formada pelos pontos 53 e 48).

G- Linha do corpo mandibular direito (formada pelos pontos 42 e 45).

$\mathrm{H}$ - Linha do corpo mandibular esquerdo (formada pelos pontos 45 e 48 ).

\subsubsection{4 - Grandezas Cefalométricas (FIGURA 19 e 20):}

Para a obtenção das medidas lineares bilaterais ou das estruturas não pareadas, a medição foi realizada da estrutura em questão até a linha de referência vertical média (Linha-X), paralelamente ao plano $Z$.

1- Ângulo do plano $Z$ (ÂPLANOZ) - Ângulo entre o plano $Z$ (8 e 2) e a linha $\mathrm{Cg}$ (Crista galli)-ENA (54 e 55) (FIGURA 19)

2- Ângulo do plano oclusal (ÂPLOCLUSAL) - Ângulo entre o plano oclusal (pontos n’s 56 e 57, construídos) e a linha Cg (Crista galli)-ENA (54 e 55) (FIGURA 19)

3- Ângulo do plano antegoniano (ÂPLANTEG)- Ângulo entre o plano antegoniano (48 e 42) e a linha $\mathrm{Cg}$ (Crista galli)-ENA (54 e 55) (FIGURA 19)

4- Desvio da espinha nasal anterior (DESVENA) - Distância (ponto -linha) entre a espinha nasal anterior (55) e a Linha-X (FIGURA 20)

5- Desvio mandibular (DESMAND)- Distância (ponto-linha) entre o mentoniano (45) e a Linha-X (FIGURA 20)

6- Desvio da linha média superior (A1) - Distância (ponto-linha) entre a linha média dos incisivos superiores (58) e a Linha-X (FIGURA 20)

7- Desvio da linha média inferior (B1)- Distância (ponto-linha) entre a linha média dos incisivos inferiores (59) e a Linha-X (FIGURA 20)

8- Ângulo antegoniano direito (ÂANTD)- Ângulo entre o ramo mandibular (42 e 37) e o corpo mandibular direito (42 e 45) (FIGURA 19)

9- Ângulo antegoniano esquerdo (ÂANTE)- Ângulo entre o ramo mandibular (48 e 53) e o corpo mandibular esquerdo (48 e 45) (FIGURA 19) 
10- Distância Z direita (DISTZD)- Distância horizontal entre a sutura frontozigomática (ponto Z) direita (2) e a Linha-X (FIGURA 20)

11- Distância $Z$ esquerda (DISTZE)- Distância horizontal entre a sutura frontozigomática (ponto Z) esquerda (8) e a Linha-X (FIGURA 20)

12- Distância CO direita (DISTCOD)- Distância horizontal entre o condílio direito (37) e a Linha-X (FIGURA 20)

13- Distância CO esquerda (DISTCOE)- Distância horizontal entre o condílio esquerdo (53) e a Linha-X (FIGURA 20)

14- Distância ZA direita (DISTZAD) - Distância horizontal entre o zygoma direito (14) e a Linha-X (FIGURA 20)

15- Distância ZA esquerda (DISTZAE) - Distância horizontal entre o zygoma esquerdo (17) e a Linha-X (FIGURA 20)

16- Distância NC direita (DISTNCD) - Distância horizontal entre a parede lateral da abertura piriforme direita (10) e a Linha-X (FIGURA 20)

17- Distância NC esquerda (DISTNCE) - Distância horizontal entre a parede lateral da abertura piriforme esquerda (12) e a Linha-X (FIGURA 20)

18- Distância J direita (DISTJD) - Distância horizontal entre o processo jugal direito da maxila (15) e a Linha-X (FIGURA 20)

19- Distância J esquerda (DISTJE) - Distância horizontal entre o processo jugal esquerdo da maxila (18) e a Linha-X (FIGURA 20)

20- Distância AG direita (DISTAGD) - Distância horizontal entre a chanfradura antegoniana direita (42) e a Linha-X (FIGURA 20)

21- Distância AG esquerda (DISTAGE) - Distância horizontal entre a chanfradura antegoniana esquerda (48) e a Linha-X (FIGURA 20)

22- Altura do primeiro molar superior direito (ALTㅌD)- Distância vertical entre 0 processo jugal direito (15) e a ponta de cúspide vestibular do primeiro molar superior direito (20) (FIGURA 20)

23- Altura do primeiro molar superior esquerdo (ALTㅌE)- Distância vertical entre o processo jugal esquerdo (18) e a ponta de cúspide vestibular do primeiro molar superior esquerdo (27) (FIGURA 20) 24- Distância CO-AG Direita (CO-AGD) - Tamanho do ramo mandibular direito, do condílio (37) até à chanfradura antegoniana (42) (FIGURA 20) 25- Distância CO-AG Esquerda (CO-AGE) - Tamanho do ramo mandibular esquerdo, do condílio (53) até à chanfradura antegoniana (48) (FIGURA 20) 
26- Distância CO-ME Direita (CO-MED) - Tamanho do lado direito da mandíbula, do condílio (37) até o mentoniano (45) (FIGURA 20)

27- Distância CO-ME Esquerda (CO-MEE) - Tamanho do lado esquerdo da mandíbula, do condílio (53) até o mentoniano (45) (FIGURA 20)

28- Distância ME-AG Direita (ME-AGD) - Tamanho do corpo mandibular direito, da chanfradura antegoniana (42) até o mentoniano (45) (FIGURA 20) 29- Distância ME-AG Esquerda (ME-AGE) - Tamanho do corpo mandibular esquerdo, da chanfradura antegoniana (48) até o mentoniano (45) (FIGURA 20)

\subsection{1 - Diferenças entre medidas bilaterais}

30- Diferença ângulo antegoniano - ÂANT - (8-9)

31- Diferença distância Z - DISTZ - (10-11)

32- Diferença distância CO - DISTCO - (12-13)

33- Diferença distância ZA - DISTZA - (14-15)

34- Diferença distância NC - DISTNC - (16-17)

35- Diferença distância J - DISTJ - (18-19)

36- Diferença distância AG - DISTAG - (20-21)

37- Diferença altura do primeiro molar superior A6 - ALT6 - (22-23)

38- Diferença distância CO-AG - CO-AG - (24-25)

39- Diferença distância CO-ME - CO-ME - (26-27)

40- Diferença distância ME-AG - ME-AG- (28-29) 


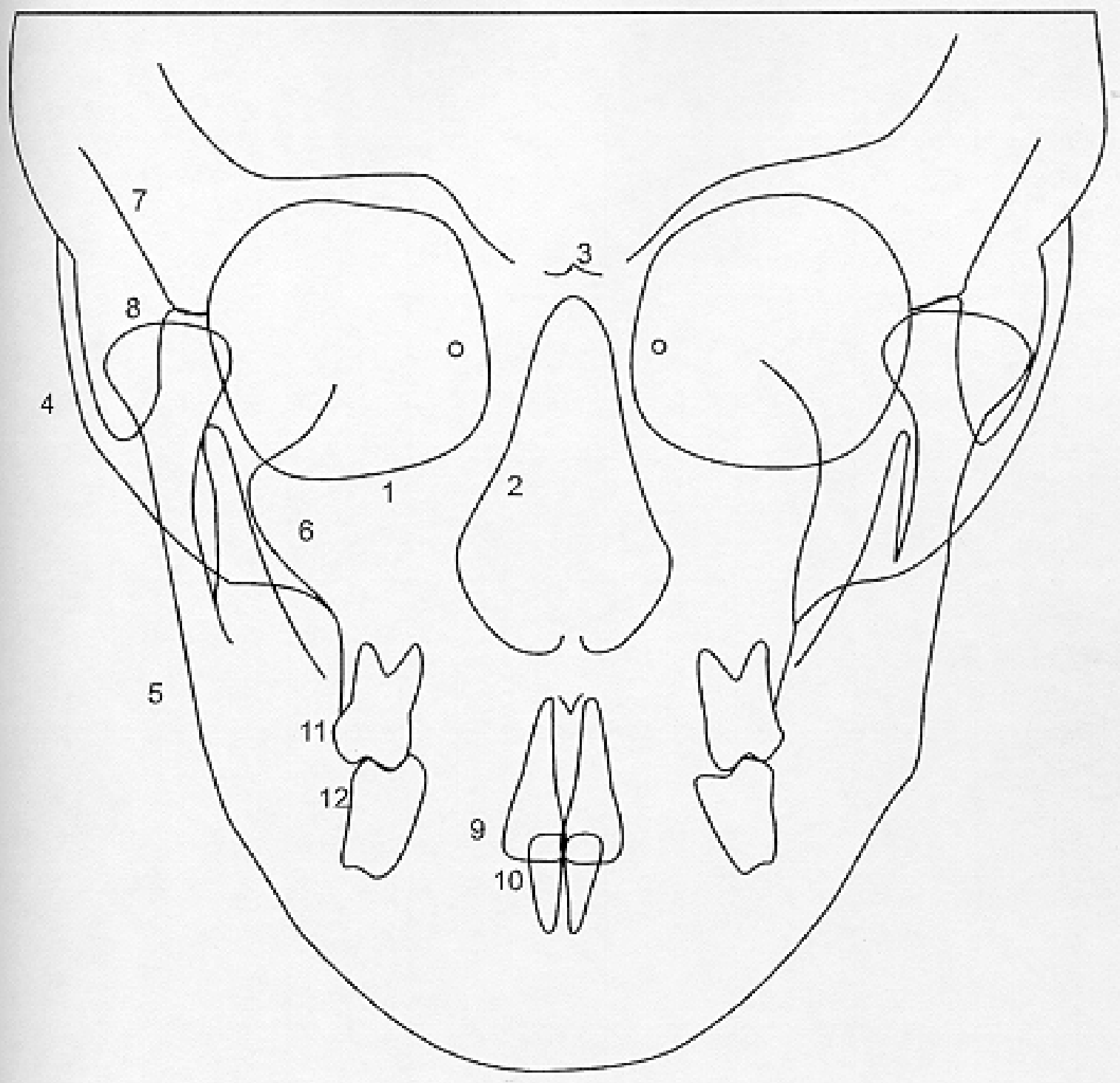

FIGURA - 16 - Estruturas anatômicas da radiografia póstero-anterior* 


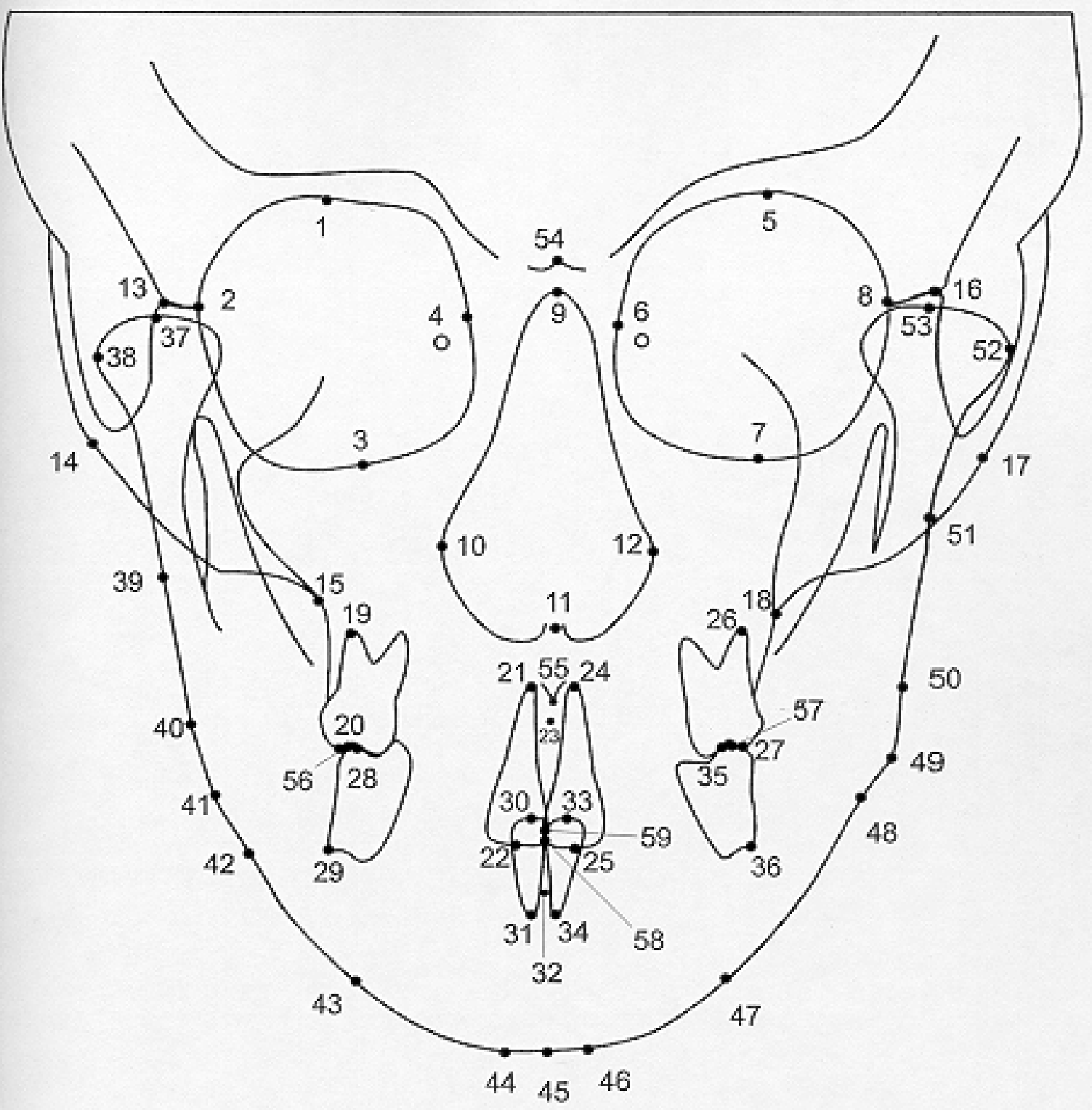

FIGURA - 17 - Pontos da radiografia póstero-anterior*

-FONTE: Figura reproduzida da pesquisa de JANSON79. 


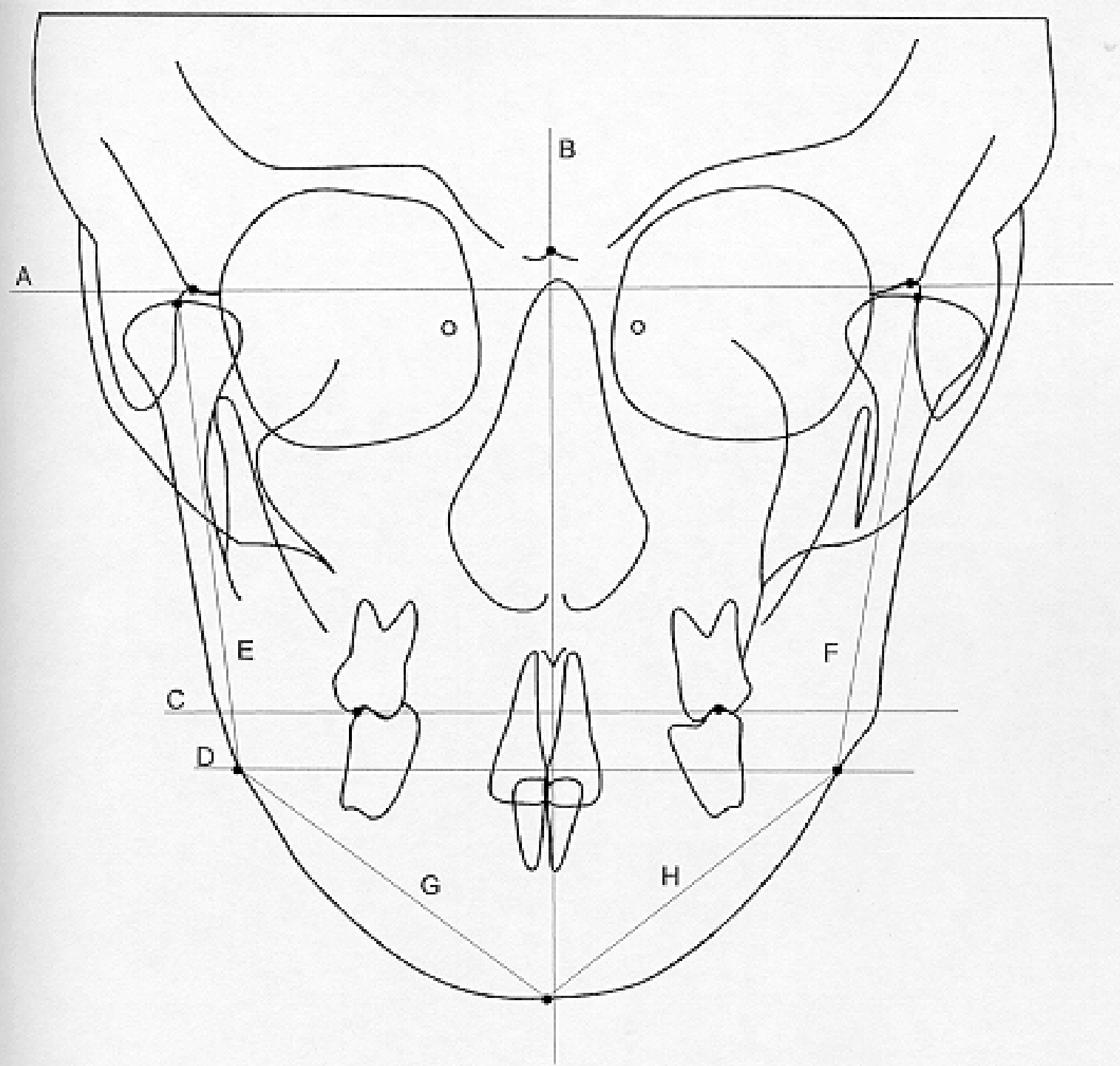

FIGURA - 18 - Linhas e planos da radiografia póstero-anterior* 


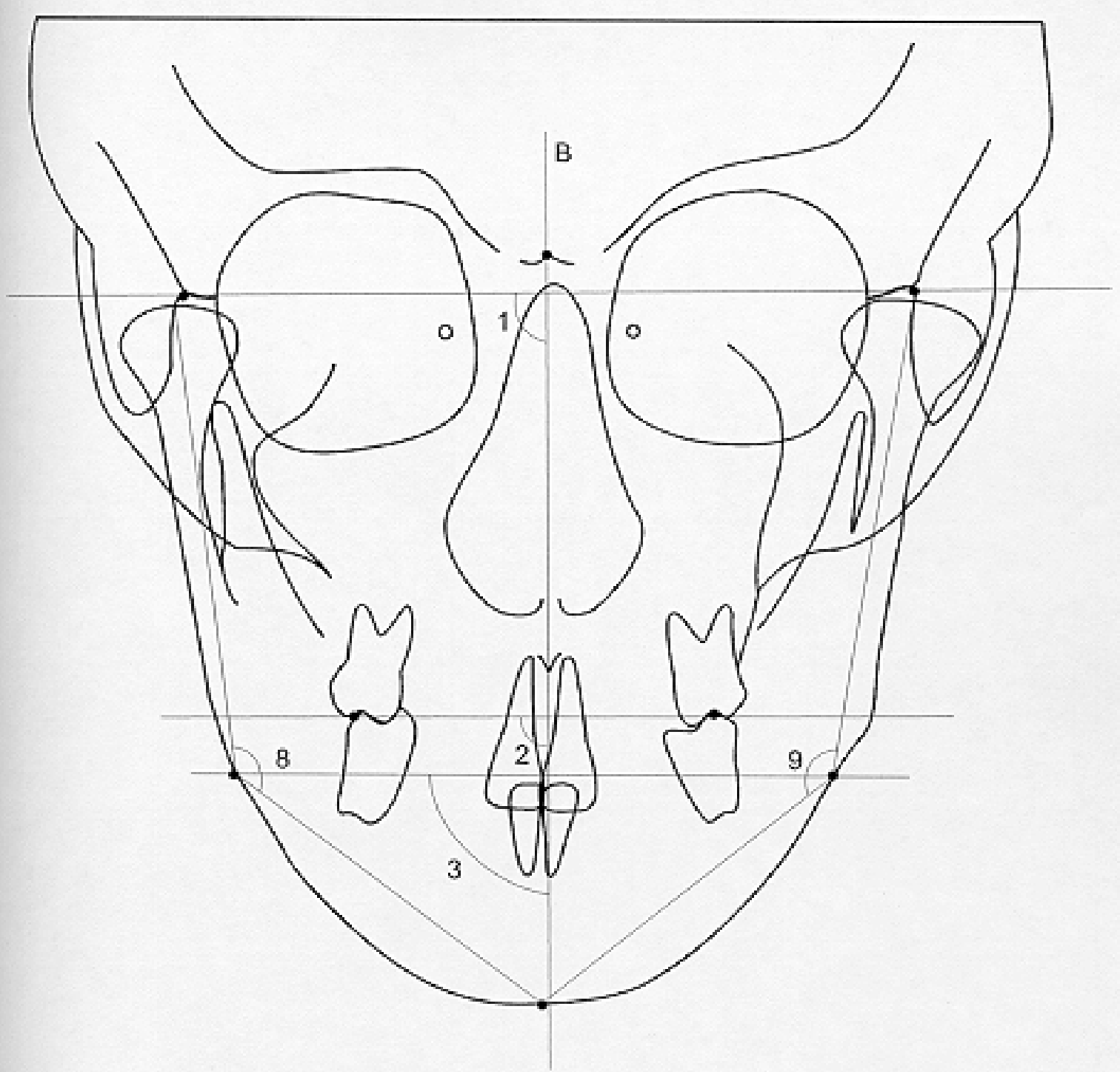

FIGURA - 19 - Grandezas angulares da radiografia póstero-anterior" 


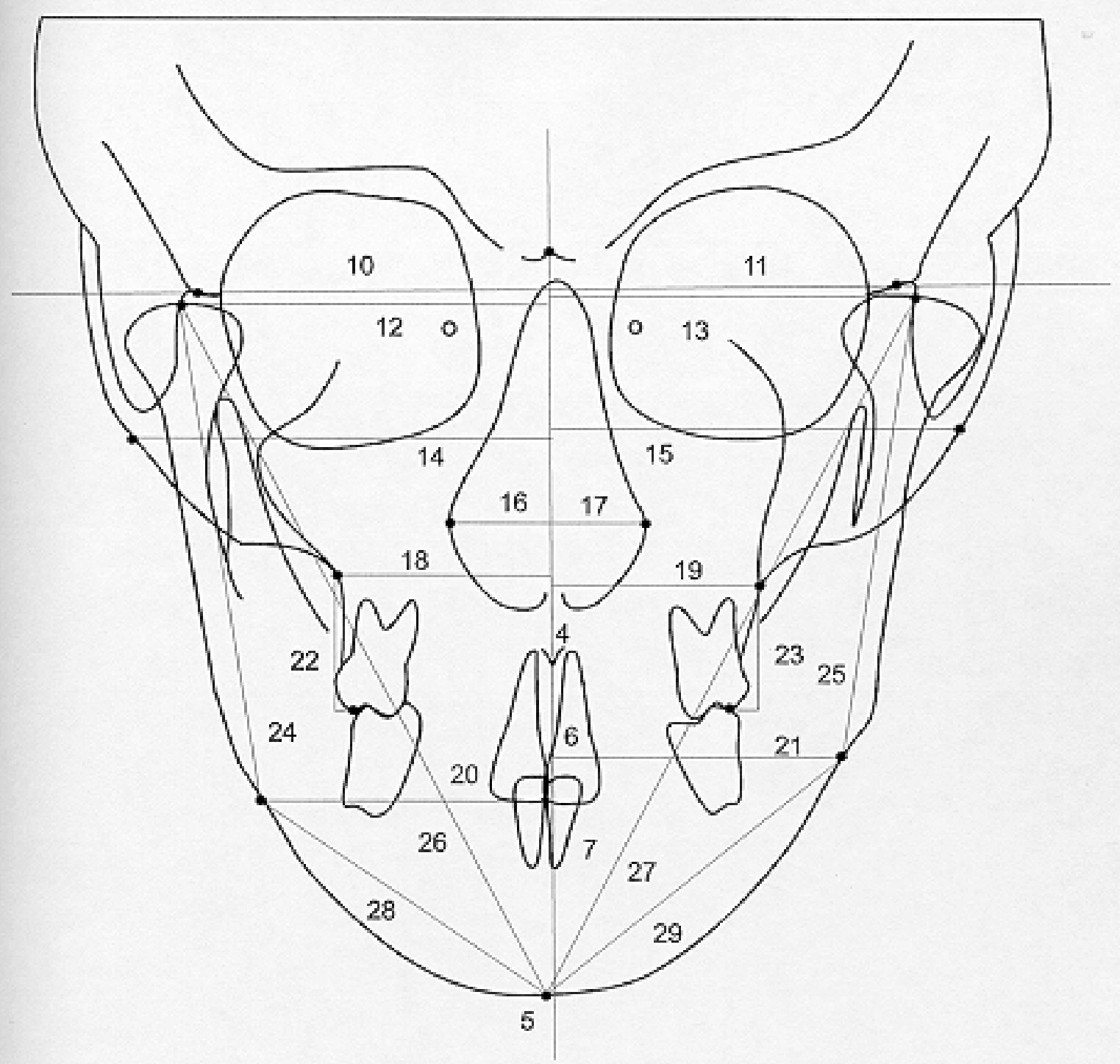

FIGURA - 20 - Grandezas lineares da radiografia póstero-anterior* 


\subsection{3 - Erro do Método}

Para a avaliação do erro intra-examinador foram retraçadas, redigitalizadas e medidas novamente as radiografias submentoniana e pósteroanterior de dez indivíduos do grupo de Classe II, subdivisão, selecionados aleatoriamente, após um mês do final de todos os traçados, somando-se ao total, 20 radiografias. A estimativa da ordem de grandeza dos erros casuais foi avaliada pela aplicação da fórmula proposta por DAHLBERG $43\left(\mathrm{Se}^{2}=\right.$ somatório $\left.d^{2} / 2 n\right)$ e a obtenção dos erros sistemáticos procedeu-se pela aplicação do teste t pareado $11,61,74,139$.

\subsection{4 - Avaliação da distribuição dos tipos de Classe II, subdivisão}

$\mathrm{Na}$ literatura ${ }^{79}$, verificourse que é possível se classificar a Classe II, subdivisão em dois tipos principais. $O$ tipo 1 se caracteriza pelo posicionamento mais para distal do molar inferior, do lado da Classe II, com conseqüente desvio da linha média dentária inferior para este lado. $\mathrm{O}$ tipo 2 se caracteriza pelo posicionamento mais para mesial do molar superior, do lado da Classe II, com conseqüente desvio da linha média dentária superior para o lado oposto. Baseando-se nessa forma de avaliação, duas examinadoras, alunas da pós-graduação em Ortodontia, em nível de Mestrado, quantificaram o número de casos que apresentavam os dois tipos principais de Classe II, subdivisão. Para tanto, observaram nas fotografias frontais os desvios das linhas médias dentárias em relação a uma linha imaginária, perpendicular ao solo, passando pelo centro da glabela ${ }^{83}$. Assim, subdividiu-se o grupo de Classe II, subdivisão em: Classe II, subdivisão - tipo 1 (linha média dentária superior coincidente e inferior desviada), Classe II, subdivisão - tipo 2 (linha média dentária inferior coincidente e superior desviada). Os casos em que houve dúvida quanto a essa classificação não foram incluídos, totalizando 9 casos.

Também se verificou a distribuição dos tipos de Classe II, subdivisão na radiografia PA. Para tanto, utilizourse a análise dos desvios das linhas médias dentárias superior e inferior em relação à linha X (FIGURA 18). Quando a linha média dentária superior coincidia ou se encontrava mais próxima desta linha, classificava-se o caso como Classe II, subdivisão - tipo 1; quando a linha média dentária inferior coincidia ou estava mais próxima desta linha, 
considerava-se Classe II, subdivisão - tipo 2. Quando as duas linhas médias dentárias superior e inferior se encontravam igualmente desviadas para lados opostos, classificou-se como casos duvidosos.

\subsection{5 - Análise Estatística}

\subsubsection{1 - Estatística Descritiva}

As distribuições dos tipos de Classe II, subdivisão nas fotografias e radiografias foram expressas em termos percentuais em relação à amostra total.

Adicionalmente, realizou-se uma análise, utilizando uma tabela de concordância, para verificar o grau de concordância entre as duas formas de avaliação dos tipos de Classe II, subdivisão, tanto na fotografia quanto na radiografia PA.

\subsubsection{2 - Comparação entre os grupos 177}

A literatura já demonstrou que a Classe II, subdivisão não apresenta uma maior assimetria esquelética que a Classe I e a oclusão normaR,79,141. Entretanto, existem especulações de que quando subdivididos quanto ao tipo, pode haver uma maior assimetria em relação à oclusão norma|81. Portanto, de acordo com a classificação dos tipos baseada na análise das fotografias, utilizourse o teste t para variáveis independentes objetivando a comparação das assimetrias entre os tipos 1 e 2 de Classe II, subdivisão com o grupo de oclusão normal. Os resultados foram considerados estatisticamente significantes para $\mathrm{p}<0,05$.

Todas estas análises foram realizadas com o programa Statistica ${ }^{5}$.

\footnotetext{
${ }^{5}$ Statistica for Windows - Release 5.0A - Copywright Statsoft, Inc. 1995.
} 
5. Resultados 


\section{5 - Resultados:}

As tabelas de 1 a 7 , referem-se aos resultados da avaliação dos erros casuais e sistemáticos. A tabela 8 se refere à distribuição dos tipos de Classe II, subdivisão, com relação às avaliações nas fotografias e radiografias pósteroanteriores e a tabela 9 representa a concordância entre as duas formas de avaliação da distribuição, verificada pelas duas examinadoras.

As tabelas de 10 a 16 representam os resultados do teste $t$ independente entre os grupos de oclusão normal e de Classe II, subdivisão tipo 1 e tipo 2. Os resultados em vermelho denotam uma diferença estatisticamente significante $(p<0,05)$.

TABELA 1 - Apresentação dos erros casuais (DAHLBERG43), e dos resultados do teste $t$ para amostras dependentes, das diferenças entre as replicações, do teste intra-examinador

Sistema de Coordenadas Mandibulares

\begin{tabular}{l|c|c|c|c}
\hline \multicolumn{5}{c}{ ÂNTERO-POSTERIOR } \\
\hline & DAHLBERG & $\begin{array}{c}\text { MEDIA } \\
\text { DIFERENÇA }\end{array}$ & $\begin{array}{c}\text { D.P. } \\
\text { DIFERENÇA }\end{array}$ & $\mathbf{p}$ \\
\hline GO-ETC & 0,53 & 0,28 & 1,09 & 0,440500 \\
\hline PPC-ETC & 0,79 & $-0,16$ & 1,65 & 0,767104 \\
\hline PDMI-ETC & 0,55 & $-0,52$ & 1,04 & 0,150181 \\
\hline PDMS-ETC & 0,33 & 0,39 & 0,57 & 0,061728 \\
\hline \multicolumn{5}{|c|}{ TRANSVERSAL } \\
\hline GO-EIC & 1,68 & $-0,79$ & 3,45 & 0,488112 \\
\hline PPC-EIC & 1,38 & $-1,05$ & 2,7 & 0,250744 \\
\hline PDMI-EIC & 1,60 & 0,06 & 3,38 & 0,956474 \\
\hline PDMS-EIC & 1,51 & $-0,65$ & 3,12 & 0,526917 \\
\hline LMM-EIC & 0,93 & $-0,38$ & 1,92 & 0,548932 \\
\hline LMDI-EIC & 0,91 & $-0,40$ & 1,88 & 0,519814 \\
\hline LMDS-EIC & 0,87 & $-0,59$ & 1,74 & 0,312850 \\
\hline
\end{tabular}


TABELA 2 - Apresentação dos erros casuais (DAHLBERG43), e dos resultados do teste $t$ para amostras dependentes, das diferenças entre as replicações, do teste intra-examinador

Sistema de Coordenadas do Assoalho Craniano ANTERO-POSTERIOR

\begin{tabular}{l|c|c|c|c}
\hline & DAHLBERG & $\begin{array}{c}\text { MEDIA } \\
\text { DIFERENÇA }\end{array}$ & $\begin{array}{c}\text { D.P. } \\
\text { DIFERENÇA }\end{array}$ & P \\
\hline PCM-ETE & 0,56 & $-0,06$ & 1,18 & 0,876548 \\
\hline GO-ETE & 0,70 & 0,27 & 1,46 & 0,574963 \\
\hline PPC-ETE & 0,41 & 0,32 & 0,81 & 0,245682 \\
\hline PDMI-ETE & 0,53 & $-0,17$ & 1,11 & 0,641684 \\
\hline PDMS-ETE & 0,45 & $-0,24$ & 0,93 & 0,436091 \\
\hline \multicolumn{5}{|c|}{ TRANSVERSAL } \\
\hline PCM-EIE & 0,42 & 0,25 & 0,85 & 0,380167 \\
\hline GO-EIE & 0,63 & $-0,06$ & 1,33 & 0,889921 \\
\hline PPC-EIE & 0,52 & 0,02 & 1,11 & 0,955980 \\
\hline PDMI-EIE & 0,68 & 0,78 & 1,17 & 0,065115 \\
\hline PDMS-EIE & 0,62 & 0,06 & 1,32 & 0,888952 \\
\hline LMM-EIE & 0,50 & 0,17 & 1,05 & 0,623705 \\
\hline LMDI-EIE & 0,37 & $-0,08$ & 0,78 & 0,755244 \\
\hline LMDS-EIE & 0,30 & 0,08 & 0,63 & 0,699114 \\
\hline
\end{tabular}

TABELA 3 - Apresentação dos erros casuais (DAHLBERG ${ }^{43}$ ), e dos resultados do teste $t$ para amostras dependentes, das diferenças entre as replicações, do teste intra-examinador

Sistema de Coordenadas Zigomaticomaxilares ÁNTERO-POSTERIOR

\begin{tabular}{l|c|c|c|c}
\hline & DAHLBERG & $\begin{array}{c}\text { MEDIA } \\
\text { DIFERENÇA }\end{array}$ & $\begin{array}{c}\text { D.P. } \\
\text { DIFERENÇA }\end{array}$ & p \\
\hline PDMI-ETPTM & 0,85 & $-0,91$ & 1,52 & 0,092161 \\
\hline PDMS-ETPTM & 0,70 & 0,10 & 1,47 & 0,835348 \\
\hline \multicolumn{4}{|c|}{ TRANSVERSAL } \\
\hline VA-EIPTM & 0,43 & $-0,13$ & 0,91 & 0,663559 \\
\hline VP-EIPTM & 0,31 & $-0,33$ & 0,57 & 0,102209 \\
\hline PDMI-EIPTM & 0,86 & 1,16 & 1,34 & 0,023272 \\
\hline PDMS-EIPTM & 0,79 & 0,70 & 1,50 & 0,176318 \\
\hline LMDS-EIPTM & 0,76 & 0,80 & 1,38 & 0,100838 \\
\hline LMM-EIPTM & 0,72 & 1,05 & 1,05 & 0,011812 \\
\hline LMDI-EIPTM & 0,66 & $-0,06$ & 1,39 & 0,895013 \\
\hline
\end{tabular}


TABELA 4 - Apresentação dos erros casuais (DAHLBERG43), e dos resultados do teste $t$ para amostras dependentes, das diferenças entre as replicações, do teste intra-examinador

Sistema de Coordenadas Dentárias ANTERO-POSTERIOR

\begin{tabular}{|c|c|c|c|c|}
\hline & DAHLBERG & $\begin{array}{c}\text { MÉDIA } \\
\text { DIFERENÇA }\end{array}$ & $\begin{array}{c}\text { D.P. } \\
\text { DIFERENÇA }\end{array}$ & p \\
\hline PDMIPCM & 0,71 & $-0,20$ & 1,50 & 0,683402 \\
\hline PDMS-PCM & 0,49 & 0,41 & 0,95 & 0,209679 \\
\hline \multicolumn{5}{|c|}{ TRANSVERSAL } \\
\hline LMDI-EIMI & 0,37 & $-0,04$ & 0,78 & 0,874851 \\
\hline LMM-EIMI & 0,50 & 0,41 & 0,96 & 0,213177 \\
\hline LMDS-EIMI & 0,55 & 0,13 & 1,15 & 0,729609 \\
\hline LMDI-EIMS & 0,45 & $-0,35$ & 0,88 & 0,241866 \\
\hline LMDS-EIMS & 0,40 & $-0,06$ & 0,85 & 0,829395 \\
\hline LMM-EIMS & 0,42 & 0,23 & 0,86 & 0,421783 \\
\hline
\end{tabular}

TABELA 5 - Apresentação dos erros casuais (DAHLBERG43), e dos resultados do teste $t$ para amostras dependentes, das diferenças entre as replicações, do teste intra-examinador

Medidas Angulares

\begin{tabular}{l|c|c|c|c}
\hline & DAHLBERG & $\begin{array}{c}\text { MÉDIA } \\
\text { DIFERENÇA }\end{array}$ & $\begin{array}{c}\text { D.P. } \\
\text { DIFERENÇA }\end{array}$ & $\mathbf{p}$ \\
\hline EIE-EIC & 0,27 & $-0,09$ & 0,56 & 0,627495 \\
\hline ETE-ETC & 0,30 & $-0,04$ & 0,64 & 0,848476 \\
\hline ETPTM-ETC & 0,33 & $-0,21$ & 0,66 & 0,344588 \\
\hline ETPTM-ETE & 0,56 & 0,24 & 1,15 & 0,527526 \\
\hline ETMI-ETE & 0,54 & $-0,12$ & 1,13 & 0,746224 \\
\hline ETMI-ETC & 0,58 & $-0,54$ & 1,08 & 0,150809 \\
\hline ETMI-ETPTM & 0,88 & $-0,95$ & 1,57 & 0,089190 \\
\hline ETMS-ETE & 0,47 & $-0,22$ & 0,97 & 0,491630 \\
\hline ETMS-ETC & 0,36 & 0,42 & 0,63 & 0,064379 \\
\hline ETMS-ETPTM & 0,75 & 0,15 & 1,58 & 0,771604 \\
\hline
\end{tabular}


TABELA 6 - Apresentação dos erros casuais (DAHLBERG43), e dos resultados do teste $t$ para amostras dependentes, das diferenças entre as replicações, do teste intra-examinador

Variáveis adicionais

\begin{tabular}{l|c|c|c|c}
\hline & DAHLBERG & $\begin{array}{c}\text { MEDIA } \\
\text { DIFERENÇA }\end{array}$ & $\begin{array}{c}\text { D.P. } \\
\text { DIFERENÇA }\end{array}$ & $\mathbf{p}$ \\
\hline PCM-LMM & 0,44 & 0,17 & 0,92 & 0,577330 \\
\hline PCM-CMM & 0,83 & $-0,06$ & 1,76 & 0,916643 \\
\hline POSM & 0,46 & 0,37 & 0,90 & 0,229701 \\
\hline POSMS & 0,35 & $-0,15$ & 0,72 & 0,529064 \\
\hline
\end{tabular}

TABELA 7 - Apresentação dos erros casuais (DAHLBERG43), e dos resultados do teste $t$ para amostras dependentes, das diferenças entre as replicações, do teste intra-examinador

RADIOGRAFIA PÓSTERO-ANTERIOR

\begin{tabular}{l|c|c|c|c}
\hline & DAHLBERG & $\begin{array}{c}\text { MEDIA } \\
\text { DIFERENÇA }\end{array}$ & $\begin{array}{c}\text { D.P. } \\
\text { DIFERENÇA }\end{array}$ & $\mathbf{p}$ \\
\hline ÁPLANOZ & 0,42 & $-0,01$ & 0,90 & 0,972773 \\
\hline APLOCLUSAL & 0,58 & $-0,04$ & 1,24 & 0,921002 \\
\hline ÁPLANTEG & 1,44 & $-0,40$ & 3,01 & 0,684565 \\
\hline DESVENA & 0,43 & 0,12 & 0,91 & 0,688461 \\
\hline DESMAND & 0,89 & $-0,01$ & 1,88 & 0,987004 \\
\hline A1 & 0,59 & 0,02 & 1,25 & 0,960799 \\
\hline B1 & 0,45 & $-0,31$ & 0,91 & 0,310492 \\
\hline AANT & 0,99 & 0,62 & 2,00 & 0,352906 \\
\hline DISTZ & 0,82 & $-0,13$ & 1,72 & 0,817308 \\
\hline DISTCO & 2,32 & 0,08 & 4,89 & 0,959897 \\
\hline DISTZA & 2,41 & 0,22 & 5,08 & 0,894275 \\
\hline DISTNC & 1,37 & 0,19 & 2,88 & 0,839557 \\
\hline DISTJ & 1,44 & 0,29 & 3,03 & 0,769755 \\
\hline DISTAG & 2,10 & 0,02 & 4,44 & 0,988965 \\
\hline ALT6 & 1,13 & 0,31 & 2,36 & 0,688470 \\
\hline CO-AG & 1,92 & 0,38 & 4,03 & 0,772522 \\
\hline CO-ME & 1,11 & 0,17 & 2,34 & 0,824131 \\
\hline ME-AG & 1,80 & 0,37 & 3,79 & 0,764636 \\
\hline
\end{tabular}


TABELA 8 - Tabela de distribuição dos tipos de Classe II, subdivisão

\begin{tabular}{c|c|c|c}
\hline & Tipo 1 & Tipo 2 & Dúvidas \\
\hline Fotografias & $61,36 \%$ & $18,18 \%$ & $20,45 \%$ \\
\hline PA & $54,54 \%$ & $34,09 \%$ & $11,36 \%$ \\
\hline
\end{tabular}

TABELA 9 - Tabela de Concordância da avaliação dos tipos de Classe II, subdivisão

\begin{tabular}{|c|c|c|c|}
\hline Foto & Tipo 1 & Tipo 2 & Dúvidas \\
\hline Tipo 1 & 16 indivíduos & 4 indivíduos & 4 indivíduos \\
\hline Tipo 2 & 8 indivíduos & 4 indivíduos & 3 indivíduos \\
\hline Dúvidas & 3 indivíduos & 0 & 2 indivíduos \\
\hline$a=0,1$ & & & \\
\hline
\end{tabular}


RADIOGRAFIA SUBMENTONIANA

TABELA 10 - Resultados do teste $t$ independente, entre os grupos de Oclusão Normal e de Classe II, subdivisão - tipos 1 e 2

Sistema de Coordenadas Mandibulares

\begin{tabular}{|c|c|c|c|c|c|c|c|c|}
\hline \multicolumn{9}{|c|}{ ÂNTERO-POSTERIOR } \\
\hline & \multicolumn{2}{|c|}{ Oclusão Normal } & \multicolumn{3}{|c|}{ Classe II, subdivisão - tipo1 } & \multicolumn{3}{|c|}{ Classe II, subdivisão - tipo 2} \\
\hline & Média & DP & Média & DP & $p$ & Média & DP & $p$ \\
\hline GO-ETC & 1,21 & 1,22 & 1,71 & 1,21 & 0,132311 & 1,55 & 1,30 & 0,504425 \\
\hline PPC-ETC & 1,32 & 0,85 & 1,58 & 1,05 & 0,297584 & 1,27 & 0,77 & 0,893364 \\
\hline PDMI-ETC & 0,96 & 0,64 & 3,00 & 1,49 & 0,000000 & 2,65 & 1,41 & 0,000016 \\
\hline PDMS-ETC & 0,96 & 0,72 & 1,43 & 0,95 & 0,041455 & 1,80 & 1,06 & 0,013380 \\
\hline \multicolumn{9}{|c|}{ TRANSVERSAL } \\
\hline GO-EIC & 1,95 & 1,25 & 2,56 & 2,01 & 0,169055 & 1,76 & 2,26 & 0,751842 \\
\hline PPC-EIC & 2,58 & 1,82 & 2,25 & 2,04 & 0,534454 & 1,20 & 0,96 & 0,047777 \\
\hline PDMI-EIC & 2,94 & 2,04 & 3,04 & 2,51 & 0,862847 & 3,12 & 2,03 & 0,824197 \\
\hline PDMS-EIC & 2,69 & 1,84 & 3,05 & 2,32 & 0,510699 & 3,37 & 2,55 & 0,397703 \\
\hline LMM-EIC & 1,88 & 1,50 & 2,18 & 1,70 & 0,479196 & 2,07 & 2,01 & 0,771169 \\
\hline LMDI-EIC & 1,72 & 1,24 & 2,02 & 1,40 & 0,392124 & 2,01 & 1,85 & 0,603180 \\
\hline LMDS-EIC & 1,55 & 1,12 & 1,58 & 1,59 & 0,945827 & 1,81 & 1,79 & 0,619345 \\
\hline
\end{tabular}

TABELA 11 - Resultados do teste $t$ independente, entre os grupos de Oclusão Normal e de Classe II, subdivisão - tipos 1 e 2

Sistema de Coordenadas do Assoalho Craniano

\begin{tabular}{l|c|c|c|c|l|l|l|l}
\hline \multicolumn{8}{c}{ ÂNTERO-POSTERIOR } \\
\hline & Oclusão Normal & \multicolumn{1}{l|}{ Classe II, subdivisão - tipo1 } & \multicolumn{2}{l}{ Classe II, subdivisão - tipo 2 } \\
\cline { 2 - 11 } & Média & DP & Média & DP & p & Média & DP & p \\
\hline PCM-ETE & 1,59 & 1,27 & 1,45 & 1,33 & 0,692632 & 1,76 & 1,38 & 0,749800 \\
\hline GO-ETE & 1,63 & 1,42 & 2,36 & 1,44 & 0,059401 & 1,96 & 1,74 & 0,578677 \\
\hline PPC-ETE & 1,68 & 1,28 & 2,23 & 1,29 & 0,109068 & 1,72 & 0,88 & 0,926343 \\
\hline PDMI-ETE & 1,04 & 0,84 & 3,14 & 1,55 & 0,000000 & 3,43 & 1,35 & 0,000000 \\
\hline PDMS-ETE & 1,02 & 0,90 & 1,32 & 1,10 & 0,256682 & 1,26 & 0,87 & 0,503561 \\
\hline ACP-ETE & 0,86 & 0,68 & 0,94 & 0,68 & 0,657489 & 1,63 & 2,37 & 0,116286 \\
\hline FCM-ETE & 1,75 & 1,38 & 2,33 & 1,88 & 0,184462 & 2,42 & 1,00 & 0,208032 \\
\hline & \multicolumn{7}{|c|}{ TRANSVERSAL } \\
\hline PCM-EIE & 0,95 & 0,68 & 1,57 & 1,31 & 0,027126 & 1,31 & 1,13 & 0,263207 \\
\hline GO-EIE & 1,78 & 1,31 & 2,81 & 1,98 & 0,023444 & 2,22 & 1,02 & 0,388404 \\
\hline PPC-EIE & 2,74 & 1,92 & 2,91 & 1,97 & 0,740746 & 2,07 & 1,73 & 0,376467 \\
\hline PDMI-EIE & 3,26 & 2,41 & 3,59 & 2,33 & 0,603380 & 3,88 & 2,75 & 0,534230 \\
\hline PDMS-EIE & 2,86 & 2,15 & 3,51 & 2,13 & 0,255286 & 2,95 & 3,76 & 0,932432 \\
\hline LMM-EIE & 2,13 & 1,87 & 2,90 & 1,96 & 0,133153 & 2,63 & 2,41 & 0,528092 \\
\hline LMDI-EIE & 1,90 & 1,67 & 2,21 & 1,86 & 0,504993 & 2,90 & 2,47 & 0,184348 \\
\hline LMDS-EIE & 1,94 & 1,32 & 2,18 & 1,69 & 0,547825 & 2,08 & 1,87 & 0,808315 \\
\hline ACP-EIE & 2,50 & 1,93 & 3,40 & 2,04 & 0,095893 & 2,70 & 2,15 & 0,807391 \\
\hline FCM-EIE & 4,30 & 2,71 & 3,62 & 2,90 & 0,364924 & 1,62 & 1,27 & 0,010698 \\
\hline BA-EIE & 1,37 & 1,17 & 1,72 & 1,22 & 0,280976 & 2,25 & 2,04 & 0,122351 \\
\hline OP-EIE & 1,50 & 1,35 & 2,23 & 1,45 & 0,055757 & 2,23 & 2,22 & 0,246959 \\
\hline
\end{tabular}


TABELA 12 - Resultados do teste $t$ independente, entre os grupos de Oclusão Normal e de Classe II, subdivisão - tipos 1 e 2

Sistema de Coordenadas Zigomaticomaxilares ÂNTERO-POSTERIOR

\begin{tabular}{l|c|c|c|c|c|c|c|c}
\hline \multicolumn{10}{c}{ ÂNTERO-POSTERIOR } \\
\hline & Oclusão Normal & \multicolumn{2}{c}{ Classe II, subdivisão - tipo1 } & \multicolumn{2}{c}{ Classe II, subdivisão - tipo 2 } \\
\cline { 2 - 12 } & Média & DP & Média & DP & p & Média & DP & p \\
\hline BC-ETPTM & 2,27 & 1,73 & 3,18 & 2,22 & 0,089425 & 1,83 & 1,43 & 0,516058 \\
\hline Z-ETPTM & 1,25 & 1,80 & 1,54 & 1,77 & 0,552502 & 3,02 & 3,57 & 0,056843 \\
\hline ACA-ETPTM & 1,13 & 1,64 & 1,44 & 1,66 & 0,482008 & 2,85 & 3,32 & 0,044697 \\
\hline A-ETPTM & 2,27 & 1,88 & 3,06 & 2,33 & 0,163918 & 1,47 & 1,55 & 0,278058 \\
\hline PDMI-ETPTM & 1,27 & 0,95 & 3,68 & 2,32 & 0,000003 & 2,66 & 1,80 & 0,004907 \\
\hline PDMS-ETPTM & 1,23 & 0,90 & 1,36 & 1,07 & 0,622386 & 1,78 & 1,16 & 0,157832 \\
\hline \multicolumn{8}{|c|}{ TRANSVERSAL } \\
\hline BC-EIPTM & 2,42 & 1,87 & 2,25 & 1,19 & 0,697978 & 1,76 & 1,03 & 0,349700 \\
\hline Z-EIPTM & 1,91 & 1,47 & 2,58 & 2,53 & 0,223406 & 1,95 & 1,46 & 0,950498 \\
\hline ACA-EIPTM & 3,84 & 2,54 & 4,05 & 3,38 & 0,792147 & 4,88 & 2,38 & 0,305327 \\
\hline A-EIPTM & 2,89 & 1,81 & 2,13 & 1,79 & 0,116442 & 2,01 & 0,93 & 0,194282 \\
\hline VA-EIPTM & 1,08 & 0,72 & 1,16 & 0,97 & 0,715200 & 0,77 & 0,62 & 0,285084 \\
\hline VP-EIPTM & 0,64 & 0,56 & 0,64 & 0,60 & 0,988650 & 0,68 & 0,74 & 0,866692 \\
\hline PDMI-EIPTM & 2,52 & 2,66 & 2,93 & 1,89 & 0,513915 & 2,96 & 2,21 & 0,674178 \\
\hline PDMS-EIPTM & 2,26 & 2,61 & 2,71 & 2,02 & 0,476857 & 2,41 & 2,29 & 0,884304 \\
\hline LMDS-EIPTM & 1,82 & 1,85 & 1,77 & 1,24 & 0,907323 & 1,95 & 1,26 & 0,853736 \\
\hline LMM-EIPTM & 1,94 & 1,92 & 2,27 & 2,03 & 0,535290 & 2,10 & 1,27 & 0,829773 \\
\hline LMDI-EIPTM & 1,76 & 1,91 & 2,25 & 2,06 & 0,361083 & 1,96 & 1,60 & 0,792957 \\
\hline
\end{tabular}

TABELA 13 - Resultados do teste $t$ independente, entre os grupos de Oclusão Normal e de Classe II, subdivisão - tipos 1 e 2

Sistema de Coordenadas Dentárias

\begin{tabular}{l|c|c|c|c|c|c|c|c}
\hline \multicolumn{10}{c}{ ÂNTERO-POSTERIOR } \\
\hline & Oclusão Normal & \multicolumn{2}{c}{ Classe II, subdivisão - tipo1 } & \multicolumn{2}{c}{ Classe II, subdivisão - tipo 2 } \\
\cline { 2 - 10 } & Média & DP & Média & DP & p & Média & DP & p \\
\hline PDMI-PCM & 1,65 & 1,15 & 3,04 & 1,93 & 0,001469 & 2,70 & 2,32 & 0,078274 \\
\hline PDMS-PCM & 1,43 & 1,14 & 2,13 & 1,31 & 0,036979 & 2,53 & 1,26 & 0,023024 \\
\hline \multicolumn{8}{|c|}{ TRANSVERSAL } \\
\hline LMDI-EIMI & 0,63 & 0,52 & 1,28 & 0,96 & 0,002042 & 1,07 & 0,68 & 0,054246 \\
\hline LMM-EIMI & 0,88 & 0,68 & 2,33 & 1,56 & 0,000024 & 1,65 & 1,31 & 0,028896 \\
\hline LMDS-EIMI & 0,73 & 0,49 & 3,98 & 1,59 & 0,000000 & 3,06 & 0,87 & 0,000000 \\
\hline LMDI-EIMS & 0,62 & 0,52 & 2,63 & 1,06 & 0,000000 & 2,41 & 1,35 & 0,000001 \\
\hline LMDS-EIMS & 0,55 & 0,47 & 0,96 & 0,71 & 0,012913 & 1,18 & 0,61 & 0,003172 \\
\hline LMM-EIMS & 0,89 & 0,74 & 2,12 & 1,64 & 0,000473 & 1,78 & 1,21 & 0,012876 \\
\hline
\end{tabular}


TABELA 14 - Resultados do teste $t$ independente, entre os grupos de Oclusão Normal e de Classe II, subdivisão - tipos 1 e 2

Medidas Angulares

\begin{tabular}{l|c|c|c|c|c|c|c|c}
\hline & \multicolumn{2}{|c|}{ Oclusão Normal } & \multicolumn{2}{c}{ Classe II, subdivisão - tipo1 } & \multicolumn{3}{c}{ Classe Il, subdivisão - tipo 2 } \\
\cline { 2 - 10 } & Média & DP & Média & DP & p & Média & DP & p \\
\hline EIE-EIC & 0,81 & 0,64 & 0,80 & 0,73 & 0,988703 & 0,78 & 0,63 & 0,930111 \\
\hline ETE-ETC & 0,84 & 0,65 & 0,78 & 0,76 & 0,759150 & 0,96 & 0,76 & 0,670081 \\
\hline ETPTM-ETC & 1,23 & 0,84 & 1,61 & 1,36 & 0,195951 & 1,03 & 0,79 & 0,565804 \\
\hline ETPTM-ETE & 1,46 & 1,02 & 1,61 & 1,39 & 0,640572 & 0,95 & 1,10 & 0,223019 \\
\hline ETMI-ETE & 1,09 & 0,87 & 3,33 & 1,65 & 0,000000 & 3,62 & 1,36 & 0,000000 \\
\hline ETMI-ETC & 1,02 & 0,67 & 3,13 & 1,47 & 0,000000 & 2,78 & 1,46 & 0,000016 \\
\hline ETMI-ETPTM & 1,38 & 1,04 & 3,85 & 2,33 & 0,000003 & 2,77 & 1,81 & 0,007327 \\
\hline ETMS-ETE & 1,04 & 0,92 & 1,39 & 1,13 & 0,206572 & 1,33 & 0,92 & 0,434392 \\
\hline ETMS-ETC & 1,00 & 0,76 & 1,50 & 1,01 & 0,038801 & 1,92 & 1,21 & 0,011291 \\
\hline ETMS-ETPTM & 1,27 & 0,97 & 1,42 & 1,13 & 0,604094 & 1,90 & 1,27 & 0,140111 \\
\hline
\end{tabular}

TABELA 15 - Resultados do teste $t$ independente, entre os grupos de Oclusão Normal e de Classe II, subdivisão - tipos 1 e 2

Variáveis adicionais

\begin{tabular}{l|c|c|c|c|c|c|c|c}
\hline & \multicolumn{2}{|c|}{ Oclusão Normal } & \multicolumn{2}{c}{ Classe II, subdivisão - tipo1 } & \multicolumn{3}{c}{ Classe II, subdivisão - tipo 2 } \\
\cline { 2 - 10 } & Média & DP & Média & DP & p & Média & DP & p \\
\hline PCM-LMM & 1,77 & 1,53 & 2,41 & 1,81 & 0,151562 & 2,23 & 1,95 & 0,477516 \\
\hline PCM-CMM & 2,25 & 1,49 & 2,32 & 1,60 & 0,852843 & 1,68 & 1,32 & 0,336149 \\
\hline POSM & 1,46 & 1,07 & 1,82 & 1,15 & 0,224347 & 1,18 & 1,02 & 0,512921 \\
\hline POSMS & 1,69 & 1,16 & 1,75 & 1,39 & 0,871195 & 1,41 & 0,94 & 0,530095 \\
\hline
\end{tabular}


TABELA 16 - Resultados do teste $t$ independente, entre os grupos de Oclusão Normal e de Classe II, subdivisão - tipos 1 e 2

RADIOGRAFIA PÓSTERO-ANTERIOR

\begin{tabular}{l|c|c|c|c|c|c|c|c}
\hline & \multicolumn{2}{|c|}{ Oclusão Normal } & \multicolumn{2}{c}{ Classe II, subdivisão - tipo1 } & \multicolumn{2}{c}{ Classe II, subdivisão - tipo 2 } \\
\cline { 2 - 10 } & Média & DP & Média & DP & p & Média & DP & p \\
\hline ÂPLANOZ & 89,90 & 1,27 & 89,68 & 1,80 & 0,585035 & 90,30 & 1,40 & 0,452195 \\
\hline ÂPLOCLUSAL & 89,34 & 1,74 & 90,02 & 1,97 & 0,171447 & 90,66 & 1,66 & 0,063441 \\
\hline ÂPLANTEG & 88,63 & 1,51 & 88,85 & 2,33 & 0,658713 & 89,15 & 3,84 & 0,551433 \\
\hline DESVENA & 1,33 & 0,84 & 1,49 & 1,45 & 0,594850 & 1,187 & 0,80 & 0,671125 \\
\hline DESMAND & 2,71 & 1,63 & 2,68 & 1,71 & 0,962305 & 1,65 & 0,88 & 0,088726 \\
\hline A1 & 1,40 & 0,90 & 1,65 & 1,58 & 0,463731 & 1,32 & 0,76 & 0,816698 \\
\hline B1 & 1,58 & 0,97 & 2,36 & 1,53 & 0,024013 & 1,70 & 1,26 & 0,773018 \\
\hline ÂANT & 2,40 & 1,51 & 3,42 & 2,81 & 0,090097 & 3,85 & 2,83 & 0,056374 \\
\hline DISTZ & 1,77 & 1,24 & 1,94 & 1,72 & 0,668091 & 1,51 & 0,90 & 0,590116 \\
\hline DISTCO & 3,20 & 2,42 & 4,23 & 3,24 & 0,175933 & 3,55 & 3,14 & 0,737586 \\
\hline DISTZA & 2,86 & 1,96 & 4,24 & 3,26 & 0,055703 & 3,30 & 2,29 & 0,590699 \\
\hline DISTNC & 2,51 & 1,57 & 2,76 & 2,55 & 0,659367 & 2,08 & 1,55 & 0,497016 \\
\hline DISTJ & 2,47 & 1,65 & 3,33 & 2,63 & 0,143171 & 2,21 & 1,69 & 0,692888 \\
\hline DISTAG & 4,25 & 3,19 & 4,27 & 3,32 & 0,981291 & 1,83 & 1,38 & 0,045924 \\
\hline ALT6 & 1,37 & 1,05 & 1,93 & 1,73 & 0,143657 & 2,21 & 2,00 & 0,112970 \\
\hline CO-AG & 2,70 & 2,10 & 3,20 & 2,39 & 0,401619 & 3,33 & 4,23 & 0,552240 \\
\hline CO-ME & 2,26 & 2,21 & 2,37 & 2,22 & 0,842044 & 2,66 & 1,11 & 0,623859 \\
\hline ME-AG & 2,28 & 1,92 & 2,85 & 2,21 & 0,297807 & 3,96 & 2,83 & 0,055496 \\
\hline ÂPLANOZ & 89,90 & 1,27 & 89,68 & 1,80 & 0,585035 & 90,30 & 1,40 & 0,452195 \\
\hline
\end{tabular}


6. Discussão 


\section{6 - Discussão}

\section{1 - Amostra Selecionada}

Avaliaram-se os critérios para seleção da amostra por meio de anamnese e exame clínico. Selecionaram-se dois grupos com características dentárias bem definidas da má oclusão em estudo e de oclusão normal. No grupo de má oclusão, incluíram-se apenas os casos que apresentavam a relação molar de Classe I de um lado e de Classe II completa do outro, pois casos com molar em relação de $1 / 2$ Classe II poderiam atenuar as reais características da Classe II, subdivisão79. Estes jovens não deveriam ter sido submetidos a tratamento ortodôntico, pois assim poderiam mascarar o verdadeiro relacionamento dos dentes com as bases apicais $79,100,104,141$.

Tanto os indivíduos pertencentes ao grupo com má oclusão como ao grupo de oclusão normal deveriam apresentar todos os dentes permanentes superiores e inferiores, em ambos os arcos dentários, até os primeiros molares 2,79,96,104,141,152. Eliminou-se, assim, a possibilidade de movimentações dentárias que ocasionariam desarranjos no relacionamento dos dentes e influenciariam o aparecimento de assimetrias dentárias 79 , pois alguns estudos demonstraram que mutilações nos arcos dentários e ausência de dentes, durante o desenvolvimento mandibular, podem provocar uma assimetria esquelética ${ }^{10,142}$ e uma remodelação condilar111.

Outro pré-requisito consistiu na ausência de deslocamento mandibular lateral durante 0 fechamento bucal, detectado durante o exame clínico2,79,104,118,141,149,152, baseado nos trabalhos de WILLIAMSON178 e SLAVICEK ${ }^{164}$ que asseguravam que a presença de um deslocamento mandibular lateral devido a algum contato prematuro, causa uma alteração da relação ântero-posterior do lado contrário ao desvio, ocasionando um diagnóstico errôneo da oclusão daquele lado. Este critério concordou com os pensamentos de SHROFF; SIEGEL ${ }^{159}$ que preconizavam que "as assimetrias resultantes de desvios funcionais mandibulares geralmente decorrem de contatos prematuros em cêntrica, causando um desvio mandibular lateral na máxima intercuspidação habitual".

Incluiu-se também a ausência de histórico de trauma facial ou condições médicas que poderiam ter alterado o crescimento das bases apicais como pré- 
requisitos para a seleção da amostra $79,104,136,141$, porque já se demonstrou que as respostas compensatórias a uma injúria podem desencadear um desequilíbrio no crescimento do côndilo e do ramo como um todo9,46,47 e já se comprovou que há uma associação entre o trauma e a assimetria mandibular92,136,159,161,163,168,183.

Houve uma tolerância máxima de três milímetros de apinhamento nos arcos dentários superior e/ou inferior, nos casos de Classe II, subdivisão, desde que simétrico, pois assim não ocasionariam assimetrias dentoalveolares decorrentes de problemas de falta de espaço em um quadrante. Em virtude da dificuldade de se encontrar más oclusões sem nenhum apinhamento, permitiut se a presença deste pequeno apinhamento 2,79,104.

Quanto ao gênero, apesar da falta de proporcionalidade entre os gêneros masculino e feminino nos dois grupos estudados, não se considerou um problema já que ARNOLD; ANDERSON; LILYEMARK, ao estabelecerem padrões de normalidade nas radiografias submentonianas, não verificaram diferenças estatisticamente significantes entre os gêneros, quanto às assimetrias. MELNIK ${ }^{106}$, avaliando as assimetrias por meio de radiografias oblíquas a $45^{\circ}$, também observou que após os 14 anos de idade, não havia mais diferenças estatisticamente significantes entre os gêneros. PONYI; SZABÓ; NYILASI133, realizando medições diretas em mandíbulas de crânios europeus de séculos passados, também não detectaram diferenças significantes entre os gêneros. Também, CHEBIB; CHAMMA ${ }^{34}$ estudando índices de assimetria craniofacial em cefalogramas póstero-anteriores, e SHEATS et al. ${ }^{154}$, pesquisando sobre a prevalência da assimetria dentária e facial em escolares americanos de ambos os gêneros, não verificaram uma associação entre o gênero e a assimetria.

No que concerne às idades entre os grupos, houve diferença, visto que o grupo de Classe II, subdivisão apresentava uma idade média de 15,3 anos e o de oclusão normal, 22,42 anos. Considerou-se esta diferença desprezível para os pacientes do gênero feminino, já que nesta idade a maior parte da maturação já tinha ocorrido. Quanto aos pacientes do gênero masculino, ainda havia uma certa quantidade de crescimento. Entretanto, MELNIK ${ }^{106}$ estudando a assimetria mandibular, verificou que existe uma probabilidade semelhante de ocorrer uma melhora ou piora desta assimetria com o crescimento, podendo- 
se, dentro de certos limites, fazer uma analogia em relação ao crescimento craniofacial, de uma forma geral. Desta maneira, a diferença de idade entre os grupos não interferiu na avaliação.

Com relação à quantidade de indivíduos em cada grupo, houve uma falta de proporcionalidade, considerando que o grupo com oclusão normal apresentava 30 indivíduos; o grupo com má oclusão de Classe II, subdivisão tipo 1, 27 indivíduos e o grupo com Classe II, subdivisão - tipo 2 apresentava apenas 8 indivíduos. hicialmente, o grupo de Classe II, subdivisão totalizava 44 indivíduos, entretanto, após a análise facial frontal, eliminaram-se os 9 casos considerados duvidosos, para a realização do teste t independente, visto que poderiam conter características de ambos os grupos, camuflando, assim, os resultados. O maior número de casos encontrados do tipo 1 confirmou os registros na literatura de que a Classe II, subdivisão se deve, principalmente, ao posicionamento distalizado do molar inferior, no lado da Classe $\|^{2,79} \mathrm{e}$ secundariamente, devido ao posicionamento mesializado do molar superior, no lado da Classe 1179 . Seria ideal se os subgrupos de Classe II, subdivisão estivessem em quantidades mais homogêneas, uma vez que as características do grupo de Classe II, subdivisão - tipo 2 não se apresentaram tão expressivas, quanto as do tipo 1. Neste grupo, a participação do molar inferior na produção da Classe II denotou maior evidência que a participação do molar superior no tipo 2. Assim sendo, este trabalho representa um estudo piloto, no que se refere a avaliação das características da Classe II, subdivisão - tipo 2.

\section{2 - Metodologia Empregada}

Obtiveram-se as radiografias submentonianas e póstero-anteriores em máxima intercuspidação habitual de acordo com LAM; SADOWSKY; OMERZA ${ }^{91}$, MONGINI; SCHMID ${ }^{112}$, O'BYRN et al.118, SCHMID; MONGINI; FELISIO149, SHAH; JOSHI152. Contrariamente, outros autores $54,140,178-180$ preconizam sua obtenção em relação cêntrica quando se deseja detectar qualquer desvio mandibular funcional que possa interferir na avaliação da assimetria mandibular, em relação à maxila e à base do crânio. Isto se aplica, principalmente, aos casos de Classe II, pois estes geralmente apresentam um maior desvio, para anterior, que aqueles com Classe 1137. Entretanto, neste trabalho, um dos critérios adotados no momento da seleção da amostra 
consistiu na ausência de desvio funcional mandibular lateral em todos os pacientes $2,79,104,118,141,152$. Desta forma, objetivou-se uma maior precisão na correta avaliação da assimetria mandibular, em relação à maxila e à base do crânio ${ }^{79}$. Baseando-se nos princípios de DAWSON 44 e OKESON ${ }^{120}$, adotourse a manipulação bilateral da mandíbula em relação cêntrica para a avaliação de qualquer desvio funcional mandibular. Desde que os pacientes não apresentassem nenhum sintoma de distúrbios temporomandibulares, considerou-se este tipo de manipulação suficiente para levar os côndilos em relação cêntrica ${ }^{143}$.

Neste estudo utilizaram-se valores absolutos, como abordado no capítulo de Material e Métodos, objetivando eliminar a possibilidade de que os valores de diferença, positivos ou negativos se cancelassem no cálculo das médias para cada grupo ${ }^{8}$. Outra razão para tal conduta deve-se ao fato de que pacientes que não apresentam assimetria facial ou dentária evidentes, demonstram diferenças esqueléticas de tamanho entre os lados direito e esquerdo da maxila e da mandíbula152,172. Além disso, MELNIK 106 demonstrou que a mandíbula se apresenta assimétrica em jovens em crescimento, em diferentes idades. Há trabalhos que demonstraram que existia um certo grau de assimetria presente no arco dentário, mesmo em pacientes com oclusão normal65,101. Ainda mais, de acordo com algumas teorias de assimetria direcionaß34,126,129,130,133,172,182, verificaram-se desvios dentários ou esqueléticos, predominantemente para um dos lados. Portanto, se os valores reais fossem utilizados, os grupos poderiam apresentar uma assimetria direcional que influiria nos resultados obtidos, levando a conclusões distorcidas 79 .

\section{3 - Considerações sobre a Mensuração das Grandezas Cefalométricas}

Aproveitando-se de recursos da informática, recorreu-se à utilização do computador para a medição das grandezas cefalométricas, possibilitando-se trabalhar com um maior número de dados em um menor período de tempo. $\mathrm{O}$ programa Dentofacial Planner 7.0, disponível na Disciplina de Ortodontia, proporcionou a medição com precisão de $0,1 \mathrm{~mm}$ ou $0,1 \mathrm{grau}$, tendo sido já utilizado em diversos trabalhos, assegurando sua fidedignidade 19,23,32,79,80,99,119,121,123,132,165. Permitiu, também, a exportação 
dos resultados obtidos para um programa de estatística, garantindo uma maior precisão na transferência de dados de um programa para outro. Assim, o método manual seria menos prático, não só por ser mais lenta a obtenção dos valores das variáveis, como também haveria uma maior possibilidade de erros durante a digitação dos valores obtidos. Portanto, além de diminuir a possibilidade de erros na fase de mensuração das medidas cefalométricas, de acordo com RICHARDSON139 a utilização do método computadorizado facilitou a manipulação de um grande número de dados.

\section{4 - Precisão da Metodologia}

Com a finalidade de avaliar a precisão e a reprodutibilidade da investigadora, os traçados anatômicos, a demarcação e digitalização dos pontos, foram realizados duas vezes para dez pacientes, selecionados aleatoriamente da amostra total, como recomendado por HOUSTON74. Assim, nesta pesquisa, utilizaram-se dez radiografias submentonianas e dez pósteroanteriores, totalizando-se 20 radiografias da amostra geral, para se calcular os erros casuais e sistemáticos.

Os erros casuais, segundo HOUSTON74, advêm das dificuldades na identificação dos pontos cefalométricos e também devido à imprecisão nas definições de certos pontos. A situação ideal é aquela em que a média das diferenças iguala-se a zero, para uma determinada medida cefalométrica repetida numa série de cefalogramas duplicados, pois isto indica que os erros casuais ocorreram de modo equilibrado nos dois sentidos, isto é, tanto para mais como para menos. No que se refere aos erros sistemáticos, caso a média das diferenças seja diferente de zero, talvez tenha havido uma tendência ao direcionamento dos resultados, de modo consciente ou inconsciente, seja subestimando-os ou superestimando-os, reiteradamente ${ }^{146}$.

Com relação aos erros casuais ${ }^{43}$, observourse nas tabelas 1 a 7 que, na radiografia submentoniana, os únicos valores acima de $1 \mathrm{~mm}$ foram os de quatro variáveis do sistema de coordenadas mandibulares (TABELA 1), todas para o sentido transversal. As variáveis referiram-se à distância do gônio, do ponto do processo coronóide e do ponto distal do primeiro molar inferior e superior ao eixo intercondilar (GO-EIC, PPC-EIC, PDMFEIC e PDMS-EIC, respectivamente), entretanto estes erros não afetaram a precisão das medidas 
realizadas. Desde que haja um equilíbrio entre os valores subestimados e os superestimados, as médias serão pouco afetadas, conforme pode ser verificado pela ausência de significância estatística na avaliação destas variáveis pelo teste t pareado 79,146 .

$\mathrm{Na}$ radiografia póstero-anterior (TABELA 7), 10 variáveis mostraram valores de magnitude acima de $1 \mathrm{~mm}$, entretanto estes erros não afetaram a precisão das medidas realizadas, já que para estas variáveis também houve ausência de significância estatística no teste t pareado.

Com relação à análise dos erros sistemáticos $11,61,74,139$, para 0 teste $t$ dependente (TABELAS 1 a 7), percebe-se que somente duas variáveis apresentaram significância estatística, pertencentes ao sistema de coordenadas zigomaticomaxilares da radiografia submentoniana, sendo 0 ponto distal do molar inferior e a linha média mandibular ao eixo interpterigomaxilar (PDMLEIPTM, LMM-EIPTM - TABELA 3). Provavelmente, a maior magnitude destes erros deveurse aos pontos que originam o eixo transpterigomaxilar e, conseqüentemente, o eixo interpterigomaxilar uma vez que as estruturas mais mediais e posteriores de cada fissura pterigomaxilar apresentam visualização reduzida nesta radiografia79,96,118,141.

Para a radiografia $P A$, nenhuma variável apresentou diferença estatisticamente significante (TABELA 7).

\section{5 - Distribuição dos tipos de Classe II, subdivisão}

De acordo com os resultados da avaliação nas fotografias (TABELA 8), observoutse que dentre os casos de Classe II, subdivisão, 61,36\% correspondem ao tipo 1, ou seja, os casos em que a linha média dentária superior se apresenta coincidente e a inferior desviada, refletindo o posicionamento mais para distal do molar inferior do lado da Classe II; $18,18 \%$ correspondem ao tipo 2, casos em que a linha média dentária inferior se encontra coincidente e a superior desviada, refletindo um posicionamento mais para mesial do molar superior, do lado da Classe II e 20,45\% correspondem aos casos duvidosos. Quando se considerou a avaliação da distribuição dos tipos de Classe II, subdivisão nas radiografias póstero-anteriores (TABELA 8), verificourse que: $54,54 \%$ dos casos constituem-se de Classe II, subdivisão tipo $1 ; 34,09 \%$ de Classe II, subdivisão - tipo 2 e 11,36\% de casos duvidosos. 
Estes resultados concordam com a pesquisa de JANSON79 que constatou que a Classe II, subdivisão se deve principalmente a um posicionamento mais para distal do molar inferior, do lado da Classe II e, secundariamente, a um posicionamento mais para mesial do molar superior, deste mesmo lado.

Houve a mesma tendência de distribuição na radiografia PA, entretanto, a concordância com a avaliação fotográfica não foi significante (TABELA 9). Neste estudo, priorizamos a avaliação da distribuição dos tipos baseada em parâmetros clínicos (avaliação fotográfica), concordando com trabalhos anteriores que afirmaram que confiar em análises cefalométricas dentoesqueléticas para o planejamento ortodôntico pode levar algumas vezes a problemas estéticos, especialmente quando o ortodontista tenta prever resultados para o tecido mole, utilizando apenas valores normais para o tecido duro7,73,124. O tecido mole que recobre os dentes e ossos pode apresentar grande variação, por isso, o padrão dentoesquelético pode ser um guia inadequado para avaliação de desarmonias faciais $27,28,93$. Alguns trabalhos, como o de BURSTONE27, ressaltaram a importância do tegumento facial, obrigando o ortodontista a avaliá-lo sempre, para o correto diagnóstico e tratamento dos pacientes; outros autores verificaram que o planejamento ortodôntico baseado em medidas esqueléticas, sem considerar a avaliação facial, pode ter resultados desastrosos, já que medidas obtidas de pontos esqueléticos podem não corresponder às medidas do tecido mole de um paciente $42,124,147$.

A correção de desvios das linhas médias dentárias deve ser realizada de forma que se obtenha a coincidência com a linha média facial, já que esta é visível clinicamente e repercute na estética facial, não necessariamente apresentando coincidência com a linha média da radiografia frontal. Alguns estudos salientaram a importância da coordenação entre linhas médias dentárias com a linha média facial, para a obtenção de uma estética satisfatória83,84, como o de JOHNSTON; BURDEN; STEVENSON84 em que utilizaram uma imagem fotográfica do sorriso de uma jovem, com a mesma expressão facial, modificando-se a linha média dentária em relação à linha média facial e verificaram que as imagens menos atraentes, tanto para os ortodontistas como para os leigos, relacionaram-se com o aumento da discrepância entre as linhas médias dentária e a facial. 
Baseando-se nestes estudos que também utilizaram a linha média facial na análise clínica como referência para avaliação de assimetrias e considerando que o padrão dentoesquelético pode ser um guia inadequado para avaliação de desarmonias faciais, o presente estudo utilizou a classificação dos tipos baseada na avaliação da fotografia, objetivando a comparação das assimetrias entre os dois subgrupos de Classe II, subdivisão (tipos 1 e 2) com o grupo de oclusão normal.

\section{6 - Resultados Obtidos nas Radiografias Submentonianas}

Nesta pesquisa utilizou-se a análise de RITUCCI; BURSTONE54,140, de acordo com a metodologia dos trabalhos de JANSON79, CRUZ40 e ROSE et al. ${ }^{141}$, objetivando avaliar a assimetria das estruturas dentoesqueléticas em relação aos sistemas de coordenadas da mandíbula, do assoalho craniano, do complexo zigomaticomaxilar, complementando-se com as variáveis adicionais. Acrescentourse a esta análise, a avaliação das assimetrias em relação ao sistema de coordenadas dentárias e as avaliações angulares entre as abscissas dos três sistemas de coordenadas da análise de RITUCCI BURSTONE54,140, de acordo com ROSE et al. ${ }^{141}$, somadas ainda às avaliações das abscissas dentárias em relação às outras abscissas mencionadas.

Objetivou-se, assim, conseguir um maior número possível de informações em relação às características dos dois subgrupos de Classe II, subdivisão, para comparação com o grupo de oclusão normal. Esta análise, já comprovada na literatura8,54,140, utiliza os forames espinhosos para estabelecer o eixo sagital de simetria da base do crânio, pois se constituem em estruturas de grande estabilidade, fácil localização e boa reprodutibilidade ${ }^{103}$. Embora nenhum ponto cefalométrico seja imutável, estas estruturas apresentam grande estabilidade e fácil localização ${ }^{79}$.

Embora GILBERT60 tenha relatado erros significantes em medidas ântero-posteriores e precisão nas medidas transversais, ao estudar radiografias submentonianas, a análise da assimetria ântero-posterior não foi afetada neste trabalho, visto que as avaliações referiram-se às diferenças entre os dois lados, que sofreram a mesma distorção. 


\subsection{1 - Sistema de Coordenadas Mandibulares(TABELA 10)}

Analisando-se a tabela 10 que se refere aos resultados da comparação entre os grupos de oclusão normal com os grupos de Classe II, subdivisão tipo 1 e Classe II, subdivisão - tipo 2, observou-se que no tipo 1 as variáveis que se apresentaram estatisticamente diferentes foram as referentes ao posicionamento ântero-posterior dos molares inferiores e superiores, em relação ao eixo transcondilar (PDMI-ETC e PDMS-ETC), sendo que a variável dos molares inferiores apresentou uma diferença maior que a dos superiores. $A$ diferença, manifestando-se mais fortemente no posicionamento ânteroposterior dos molares inferiores, sugere que são esses dentes, do lado da Classe II, que na maioria dos casos, estão posicionados mais para distal, que os do lado oposto, em relação ao eixo transcondilar2,79. No grupo de Classe II, subdivisão - tipo 2, as duas variáveis PDMLETC e PDMS-ETC apresentaram uma diferença estatisticamente significante, sugerindo que mesmo quando a Classe II, subdivisão é provocada pela posição mais mesial do molar superior, do lado da Classe II, ainda há participação de diferenças de posição ânteroposterior entre os molares inferiores, concordando com os resultados do estudo de $\mathrm{CRUZ}^{40}$ quando analisou as alterações dentoesqueléticas do subgrupo de Classe II, subdivisão tratado com o protocolo de extração de um pré-molar superior do lado da Classe II. Nenhuma medida esquelética mostrou diferença significante, concordando com trabalhos semelhantes já realizados ${ }^{79,141}$.

No sentido transversal do sistema de coordenadas mandibulares, nenhuma variável apresentou diferença estatisticamente significante, para o grupo de Classe - tipo 1. Como não houve diferença estatisticamente significante entre o posicionamento lateral das linhas médias entre os dois grupos e o apinhamento máximo permitido foi de 3mm (simétrico), deve-se esperar que o arco inferior na Classe II, subdivisão - tipo 1, se apresente de forma assimétrica, uma vez que os dentes de um lado estarão mais para distal, em relação aos do lado oposto, em uma base óssea relativamente simétrica79. Outros trabalhos concordam com esta premissa, como os resultados de ALAVI; BEGOLE; SCHNEIDER ${ }^{2}$, que encontraram maior assimetria nos arcos dentários de casos de Classe II, subdivisão, comparados com casos de oclusão normal, assim como o trabalho de HECHTER69, em que se encontrou uma maior assimetria dos arcos dentários em casos de má oclusão, quando 
comparados aos de oclusão normal, e o de MARTINS DE ARAÚJO; SCHIRMER; ALMEIDA ${ }^{104}$ que verificaram uma maior freqüência de assimetrias no arco inferior, na Classe II, subdivisão. Para o grupo de Classe II, subdivisão

- tipo 2, apenas a variável do ponto do processo coronóide ao eixo intercondilar (PPC-EIC) apresentou diferença estatisticamente significante. Estes não eram os resultados esperados para os dois grupos de Classe II, subdivisão, pois se previa que a linha média dentária inferior estivesse desviada no tipo 1 e que a linha média dentária superior estivesse desviada no tipo 2.

\subsection{2 - Sistema de Coordenadas do Assoalho Craniano (TABELA 11)}

Os forames espinhosos foram adotados como parâmetro neste sistema de coordenadas, para a medição das diversas estruturas dentárias e esqueléticas, de acordo com trabalhos de MOSS; SALENTIJN114 que demonstraram que a passagem e a localização dos feixes neuromusculares, durante o crescimento, não podem ser violadas. Outros trabalhos, como o de MARMARY; ZILBERMAN; MIRSKY103 utilizaram a bissetriz perpendicular de uma linha unindo os dois forames espinhosos como a linha média craniana. Estes estudos, juntamente com os publicados por FORSBERG; BURSTONE; HANLEY54 e JANSON79, contribuíram na escolha do plano sagital mediano, da base craniana, neste trabalho.

O posicionamento ântero-posterior dos molares inferiores, em relação ao eixo transespinhosos (PDMFETE), apresentou-se significantemente diferente entre os dois subgrupos de Classe II, subdivisão e o grupo de oclusão normal, demonstrando o posicionamento mais distal assumido por esses dentes, no lado da Classe II, mesmo no grupo de Classe II, subdivisão - tipo 2, agora em relação a estruturas não situadas em sua base óssea (TABELA 11), concordando também com os resultados obtidos por ALAVI; BEGOLE; SCHNEIDER ${ }^{2}$, ROSE et al. ${ }^{141}$ e JANSON79. Não houve diferenças quanto à assimetria esquelética das estruturas avaliadas, entre os grupos. Neste sistema de coordenadas, a posição ântero-posterior dos molares superiores, em relação ao eixo transespinhosos não apresentou uma diferença estatisticamente significante para nenhum dos subgrupos. Como mencionado anteriormente, essa participação menos evidente do molar superior 
estabelecendo a Classe II, subdivisão - tipo 2 pode ser atribuída ao reduzido número de casos neste subgrupo, quando comparado com a participação do molar inferior na causa da Classe II, subdivisão - tipo 1.

No sentido transversal, comparado-se o grupo de oclusão normal com o de Classe II, subdivisão - tipo 1 , as variáveis que apresentaram diferenças estatisticamente significantes foram o ponto condilar médio (PCM) e gônio (GO), sendo que no grupo com Classe II, os valores absolutos foram sempre maiores que no grupo com oclusão normal (TABELA 11). Sendo variáveis mandibulares, indica uma tendência para uma maior assimetria esquelética mandibular, em relação ao assoalho craniano, no grupo com Classe II, subdivisão - tipo 1. ROSE et al. ${ }^{141}$ não encontraram essas diferenças esqueléticas quando compararam um grupo com Classe II, subdivisão, com outro com má oclusão de Classe I. Talvez a explicação para isto seja justamente que eles utilizaram, para comparação, um gupo com Classe I, enquanto que neste estudo, utilizourse um grupo com oclusão normal. Já na comparação do grupo de oclusão normal com o de Classe II, subdivisão - tipo 2, apenas a variável da fossa craniana média (FCM) apresentou diferença estatisticamente significante.

\subsection{3 - Sistema de Coordenadas Zigomaticomaxilares (TABELA 12)}

No sentido ântero-posterior, a posição ântero-posterior dos molares inferiores em relação ao eixo transpterigomaxilar (PDMFETPTM) apresentou diferença estatisticamente significante para os dois tipos de Classe II, subdivisão, mas, a diferença foi mais evidente no grupo de Classe II, subdivisão - tipo 1, indicando a grande participação dessa variável neste subgrupo de Classe II, subdivisão. A posição da abóbada craniana anterior em relação ao eixo transpterigomaxilar (ACA-ETPTM) foi estatisticamente diferente apenas na comparação do grupo de oclusão normal com o grupo de Classe II, subdivisão - tipo 2. As demais variáveis desse sistema de coordenadas não se apresentaram estatisticamente diferentes entre os grupos, demonstrando uma pequena participação dos componentes esqueléticos, visto que apenas uma variável esquelética apresentou significância estatística.

Com relação ao sentido transversal, nenhuma variável apresentou diferença estatisticamente significante. 
Analisando o comportamento das linhas médias dentárias, mesmo não apresentando diferenças estatisticamente significantes, observou-se que no grupo de Classe II, subdivisão - tipo 1, houve um maior desvio da linha média inferior (LMDFEIPTM), comparando-se com o valor desta variável no grupo de Classe II, subdivisão - tipo 2, confirmando a maior participação do molar inferior no subgrupo de Classe II, subdivisão - tipo 1. Analogamente, a linha média dentária superior (LMDS-EIPTM) apresentou um maior desvio no grupo de Classe II, subdivisão - tipo 2, quando comparada ao valor desta variável no grupo de Classe II, subdivisão - tipo 1, indicando uma tendência de maior contribuição do molar superior na Classe II, subdivisão - tipo 2.

\subsection{4 - Sistema de Coordenadas Dentárias (TABELA 13)}

No sentido ântero-posterior, analisando-se as variáveis que relacionam as posições dos primeiros molares inferiores e superiores com o ponto condilar médio (PDMI-PCM e PDMS-PCM), observa-se que no grupo de Classe II, subdivisão - tipo 1, estas duas variáveis foram estatisticamente significantes, com uma maior diferença para o PDMIPCM, novamente nota-se a maior participação dos dentes inferiores na manifestação da má oclusão de Classe II, subdivisão - tipo 1 , como já foi relatado na literatura2,79,141. No grupo de Classe II, subdivisão - tipo 2, apenas a variável PDMS-PCM mostrou-se estatisticamente significante, indicando uma maior contribuição do molar superior neste subgrupo de Classe II, subdivisão.

No sentido transversal, o sistema de coordenadas dentárias do grupo de Classe II, subdivisão - tipo 1 apresentou uma diferença significante quanto ao posicionamento lateral das linhas médias inferior e superior, em relação aos eixos intermolares inferiores e superiores (LMDIEIMI, LMDI-EIMS, LMDS-EIMI, LMDS-EIMS). Já se previam desvios das linhas médias dentárias inferior ou superior, em relação ao eixo intermolares do arco oposto, visto que os casos selecionados eram de subdivisão e apresentavam apenas um apinhamento mínimo e simétrico. Entretanto, observou-se também um desvio das linhas médias dentárias em relação aos eixos intermolares de seu próprio arco dentário. Os desvios estatisticamente significantes para as duas linhas médias sugerem uma assimetria das formas dos arcos superior e inferior na Classe II, subdivisão - tipo 1 como já demonstrado2,69,79. O desvio da linha média 
mandibular, em relação ao eixo intermolares inferiores (LMM-EIMI), sugere, novamente, uma disposição assimétrica dos dentes inferiores em sua base óssea. A linha média mandibular inferior também apresentou um maior desvio, em relação ao eixo intermolares superiores (LMM-EIMS), no grupo com subdivisão - tipo 1 , do que no grupo com oclusão normal. Tais resultados sugerem um deslocamento dos dentes superiores para um dos lados, um desvio dentoalveolar e/ou esquelético mandibular para o lado oposto, ou, ainda, uma combinação desses fatores, em casos de Classe II, subdivisão tipo 1. No grupo de Classe II, subdivisão - tipo 2, somente a variável LMDF EIMI não foi significante, indicando um arco inferior mais simétrico em casos de Classe II, subdivisão - tipo 2, como já afirmado anteriormente ${ }^{79}$.

\subsection{5 - Medidas Angulares (TABELA 14)}

Os ângulos entre os eixos condilares aos eixos dos forames espinhosos e os ângulos referentes aos eixos transcondilar e transespinhoso ao eixo transpterigomaxilar (EIE-EIC, ETE-ETC, ETPTM-ETC e ETPTM-ETE) não mostraram diferenças estatisticamente significantes entre os grupos, demonstrando que geralmente não há alteração esquelética do posicionamento angular mandibular na Classe II, subdivisão - tipos 1 e 2, em relação à base do crânio e em relação à maxila. Mesmo o grupo de Classe II, subdivisão - tipo 1, em que se esperava alguma assimetria mandibular, não se verificou assimetria posicional da mandíbula.

$O$ ângulo entre 0 eixo transpterigomaxilar e 0 eixo transespinhosos (ETPTM-ETE) não se apresentou estatisticamente diferente entre os grupos, demonstrando um posicionamento simétrico também da maxila, em relação ao assoalho craniano, na má oclusão de Classe II, subdivisão - tipos 1 e 2.

Os ângulos entre o eixo transmolar inferior e os eixos transespinhosos, transcondilar e transpterigomaxilar (ETMFETE, ETMI-ETC, ETMI-ETPTM) apresentaram-se estatisticamente diferentes entre os grupos, demonstrando a grande participação de um posicionamento assimétrico dos dentes inferiores, em relação ao crânio, à sua base apical e à maxila, para produzir a subdivisão - tipo 1, como ficou anteriormente demonstrado2,79,141, além de contribuir também para a produção da Classe II, subdivisão - tipo 2. ROSE et al. ${ }^{141}$ também encontraram resultados semelhantes entre o eixo transmolar inferior e 
os eixos transcondilar e transespinhosos (ETMI-ETC, ETMIETE). O ângulo entre o eixo transmolar superior e o eixo transcondilar (ETMS-ETC) apresentou-se estatisticamente diferente para os dois tipos de Classe II, subdivisão, mas não houve diferenças entre os grupos quanto aos ângulos formados pelo eixo transmolar superior e os eixos transespinhosos e transpterigomaxilar (ETMS-ETE, ETMS-ETPTM), tanto para o grupo de Classe II, subdivisão - tipo 1, quanto tipo 2. Sugerindo assim, que os molares dispõem-se simetricamente em relação à base do crânio e à maxila, enquanto apresentam uma pequena rotação entre o eixo transmolar superior e o eixo transcondilar, indicando, possivelmente, uma ligeira rotação do eixo intermolar superior em um sentido e uma leve rotação mandibular em sentido contrário, não evidenciada quando avaliada em relação a outros parâmetros. A contribuição maior para a relação de Classe II, dos dentes posteriores inferiores localizando-se mais para distal, e a menor contribuição dos molares superiores, conforme evidenciado nos outros sistemas de coordenadas e neste, mostram que há uma tendência de diminuição da assimetria dentoalveolar em direção cefálica e portanto, indiretamente, também favorecem a teoria de que há um decréscimo da assimetria esquelética em direção cefálica, de acordo com PECK; PECK; KATAJA ${ }^{126}$ e GRAYSON; MCCARTHY; BOOKSTEIN63.

Semelhante ao trabalho de JANSON79, em que comparou um grupo de Classe II, subdivisão com outro de oclusão normal, neste estudo, mesmo se subdividindo o grupo de Classe II, subdivisão em dois tipos distintos e comparando-os individualmente com o de oclusão normal, não houve diferença entre o ângulo formado pelos eixos transcondilar, transforame espinhoso e transpterigomaxilar, demonstrando-se a ausência de um posicionamento assimétrico da mandíbula em relação ao complexo craniofacial, e também não houve a presença de uma assimetria mandibular, como se esperava no tipo 1.

Tais resultados corroboram um posicionamento mais para distal dos primeiros molares inferiores na mandíbula, na constituição da Classe II, subdivisão - tipo 1, evidenciado pelas variáveis PDMLETC (TABELA 10), PDMI-ETE (TABELA 11), PDMI-ETPTM (TABELA 12), e PDMI-PCM (TABELA 13). Na comparação entre o grupo de oclusão normal com o de Classe II, subdivisão - tipo 2, apesar de estatisticamente significantes, as variáveis 
PDMI-ETC (TABELA 10), PDMI-ETE (TABELA 11) e PDMI-ETPTM (TABELA 12) apresentaram uma diferença menor e a variável PDMHPCM (TABELA 13) não se mostrou estatisticamente significante, já que neste subgrupo há uma tendência de maior participação do molar superior na constituição da subdivisão.

\subsection{6 - Variáveis Adicionais (TABELA 15)}

As variáveis adicionais esqueléticas, que constituem a medição do ponto condilar médio até à linha média mandibular e até o contorno médio da mandíbula (PCM-LMM, PCM-CMM), não se apresentaram significantemente diferentes nos dois tipos de Classe II, subdivisão, mostrando, de uma outra maneira, a ausência de diferença esquelética do tamanho dos lados da mandíbula, na constituição da subdivisão, tanto tipo 1 , quanto tipo 2, concordando com ROSE et al. ${ }^{141}$ e JANSON79. As posições laterais dos primeiros molares inferiores e superiores, em relação à borda mandibular(POSM, POSMS), também não apresentaram diferenças estatisticamente significantes entre os grupos, não evidenciando nenhum posicionamento lateral dos molares na Classe II, subdivisão, dentro de sua base apical.

\section{7 - Resultados Obtidos nas Radiografias Póstero-Anteriores - PA}

\section{(TABELA 16)}

A escolha de uma linha fixa de referência, a partir da qual se obtenham as medidas representa um dos principais problemas em análise de assimetria nas radiografias póstero-anteriores. Neste trabalho, utilizourse o método de HARVOLD66,67, também utilizado por JANSON79 e CRUZ ${ }^{40}$, que consiste em traçar uma linha vertical denominada de linha-X, através da Crista galli, perpendicular a outra linha horizontal, conectando as duas partes laterais da sutura fronto-zigomática, para representar o plano mediano. A escolha deste método de construção da linha média foi por não depender de nenhum ponto maxilar ou mandibular, além da comprovação na literatura66,67 e também porque a órbita látero-superior apresenta pequena variabilidade, como demonstrado por PECK; PECK; KATAJA ${ }^{126 .}$

Na comparação do grupo de oclusão normal com o grupo de Classe II, 
subdivisão - tipo 1, a única variável que apresentou diferença estatisticamente significante foi a medida da linha média dentária inferior em relação à linha-X (B1), refletindo o posicionamento distalizado do molar inferior no lado da Classe II, no tipo 1. Este resultado difere do obtido na radiografia submentoniana, no sistema de coordenadas do assoalho craniano, em que a linha média dentária inferior não se apresentou desviada em relação ao eixo interespinhosos (LMDIEIE, TABELA 11). Possivelmente, essa falta de concordância de resultados deva-se ao fato de que na radiografia submentoniana, o parâmetro de avaliação de desvio da linha média seja o eixo interespinhosos que apresenta, provavelmente, menor alteração de posição do que as bordas laterais das órbitas que constituíram os pontos para a construção da linha-X, utilizada na radiografia póstero-anterior. Estes resultados corroboram com os de outros trabalhos, como o de JANSON79 que constatou a presença de um desvio da linha média dentária inferior em relação ao plano sagital mediano em pacientes com Classe II, subdivisão. O resultado da radiografia póstero-anterior é mais interessante do ponto de vista clínico, pois o cálculo do desvio das linhas médias dentárias, em relação à uma linha imaginária, representando o plano sagital mediano, é mais fácil e útil do que procurar relacionar as linhas médias dentárias aos eixos de coordenadas da base do crânio. Estes desvios das linhas médias dentárias representam o reflexo dos posicionamentos assimétricos dos molares inferiores ou superiores, do lado da Classe II, na má oclusão de Classe II, subdivisão79. Os resultados, em modelos de gesso, de MARTINS DE ARAÚJO; SCHIRMER; ALMEIDA104 apontaram para uma maior freqüência do desvio da linha média inferior do que da superior, em más oclusões de Classe II, subdivisão, o que ratifica este raciocínio. Quanto às outras variáveis da radiografia póstero-anterior, ALAVI; BEGOLE; SCHNEIDER ${ }^{2}$ também verificaram que os valores para a assimetria maxilar no grupo com má oclusão de Classe II, subdivisão, foram semelhantes aos do grupo com oclusão normal, demonstrando que a assimetria esquelética na Classe II, subdivisão, é semelhante à da oclusão normal. MARTINS DE ARAÚJO; SCHIRMER; ALMEIDA ${ }^{104}$, de maneira semelhante, não encontraram assimetrias esqueléticas na Classe II, subdivisão, ao compararem os lados direito e esquerdo, dos pacientes, com a mesma técnica radiográfica. Os resultados das outras variáveis que não apresentaram diferenças 
estatisticamente significantes também são semelhantes aos de SHORE ${ }^{156}$ e LETZER; KRONMAN95, que utilizaram a radiografia póstero-anterior para avaliar a assimetria em grupos de más oclusões inespecíficas, em comparação com grupos de oclusão normal e ao de JANSON79 que também avaliou assimetrias na radiografia PA, comparando um grupo de oclusão normal com um de Classe II, subdivisão.

Para o grupo de Classe II, subdivisão - tipo 2, somente a distância horizontal entre a chanfradura antegoniana e a linha X (DISTAG) apresentou diferença estatisticamente significante. Seria esperado que, neste subgrupo tipo 2, a linha média dentária superior em relação à linha $X(A 1)$ exibisse uma diferença estatisticamente significante, refletindo o posicionamento assimétrico do molar superior, entretanto, isto não ocorreu, possivelmente devido ao número reduzido de casos no tipo 2. Os resultados da pesquisa de CRUZ40 mostraram que os casos de Classe II, subdivisão tratados com extração de um pré-molar superior do lado da Classe II, ainda persistiram apresentando um desvio da linha média superior em relação à linha $X$, maior que o normal. Segundo esta autora 40 , isto provavelmente ocorreu devido ao fato de que mesmo nesses casos em que o fator causal principal da Classe II, subdivisão foi a posição mais para mesial do molar superior do lado da Classe II, ainda houve certa participação assimétrica do molar inferior. Assim, analogamente aos resultados de $C R U Z 40$, observou-se que a posição mesializada do molar superior na Classe II, subdivisão - tipo 2, não se mostrou tão expressiva, quanto o posicionamento distalizado do molar inferior no tipo 1.

\section{8 - Considerações gerais}

Mesmo subdividindo em tipos 1 e 2, os principais componentes que contribuem para a relação ântero-posterior assimétrica na Classe II, subdivisão, tanto tipo 1, quanto tipo 2 na radiografia submentoniana, são dentoalveolares, quando comparados com casos de oclusão normal, demonstrando um comportamento semelhante aos estudos com os subgrupos combinados, comparados com Classe I e oclusão normal2,80,141. Embora ALAVI; BEGOLE; SCHNEIDER ${ }^{2}$ tenham encontrado uma maior participação dentoalveolar na produção da Classe II, subdivisão, também, admitiram uma participação de fatores esqueléticos, em segundo plano. No presente estudo, com diversas 
variáveis, a participação de assimetrias esqueléticas na Classe II, subdivisão, em comparação com a oclusão normal foi muito pequena. Estes resultados contrariam as especulações sobre a possibilidade de se encontrar assimetrias esqueléticas na Classe II, subdivisão, quando subdividida em tipos distintos, já que as reais características de cada tipo poderiam estar atenuadas ${ }^{81}$. Assim, os resultados deste estudo corroboram a menor participação esquelética na Classe II, subdivisão, denotando grande importância no que se refere ao tratamento desta má oclusão, pois orienta o ortodontista para um problema eminentemente dentoalveolar.

Analogamente a um estudo semelhante ${ }^{79}$, observourse nesta pesquisa que a Classe II, subdivisão - tipo 1 ocorre em uma maior porcentagem, caracterizando-se por um posicionamento mais para distal do primeiro molar inferior do lado da Classe II. Conseqüentemente ao posicionamento dos molares houve um desvio da linha média dentária inferior na Classe II, subdivisão - tipo 1, para o lado da Classe II, em relação aos diversos eixos das ordenadas dos sistemas de coordenadas, e também em relação à linha de simetria, na radiografia PA. Na Classe II, subdivisão - tipo 2 houve uma tendência de posicionamento mais para mesial do molar superior para o lado da Classe II, com desvio da linha média dentária superior para o lado oposto da Classe II. Uma possível explicação para a participação do molar superior no tipo 2 não ter sido tão evidente quanto a participação do molar inferior no tipo 1 , pode ser devido ao número reduzido de casos no subgrupo de Classe II, subdivisão.

Os resultados obtidos, de maneira geral, diferem de pesquisas que demonstraram uma tendência para a maxila ser mais assimétrica que a mandíbula ou que as regiões dentoalveolares $152,156,172$, pelo menos quando se compara um grupo com Classe II, subdivisão, com outro de oclusão normal. Não houve nenhuma diferença estatisticamente significante entre os grupos, com o teste $\mathrm{t}$, quanto à assimetria esquelética maxilar nas radiografias submentoniana ou PA, concordando com JANSON79. Aliás, a tendência é justamente inversa, ou seja, de que haja uma diminuição da assimetria esquelética em direção cefálica63,126.

JANSON81 especulou sobre a possibilidade de encontrar assimetrias esqueléticas ao se subdividir um grupo de Classe II, subdivisão, de acordo com 
o posicionamento dos molares. Porém, neste estudo em que se comparou isoladamente um grupo de Classe II, subdivisão - tipo 1 e outro grupo de Classe II, subdivisão - tipo 2 com um grupo de oclusão normal, observourse uma ínfima participação de assimetria esquelética na Classe II, subdivisão, concluindo-se que as diferenças entre os dois grupos se devam, preponderantemente, a fatores dentoalveolares.

\section{9 - Considerações clínicas sobre o tratamento da Classe II, subdivisão}

Há uma grande variedade de terapêuticas para a má oclusão de Classe II, subdivisão, sendo importante a determinação dos fatores etiológicos deste problema, se provém de uma assimetria dentária, esquelética ou de uma combinação destas características 79,138 .

O plano de tratamento deve-se voltar para as características e severidade da má oclusão, a idade ${ }^{169}$ e cooperação do paciente $29,30,40,79,82,108,170,181$. Para a realização de uma terapia conservadora, utiliza-se a ortopedia funcional52,85,107,108,112,136,144,159 e os aparelhos extrabucais assimétricos ${ }^{162,181}$ que distalizam os molares mesializados, associados à ortodontia fixa, evitando-se as extrações dentárias com uma mecânica assimétrica. Utilizam-se os aparelhos funcionais em pacientes na fase ativa de crescimento, visando corrigir as discrepâncias ântero-posteriores, verticais e transversais pela restrição e/ou redirecionamento do crescimento das bases apicais; além de mudanças no perfil facial tegumentar, já que a hipofunção muscular pode ser significantemente compensada durante a terapia ortopédica. Porém, o tratamento somente com aparelhos funcionais nem sempre é eficaz, necessitando da terapia ortodôntica corretiva geralmente após a terapia funciona ${ }^{41,70}$.

Deve-se realizar a terapia com extrações assimétricas objetivando uma mecânica simétrica, porém em casos esqueléticos severos, utiliza-se a combinação de ortodontia e cirurgia ortognática, com ou sem extrações ${ }^{30}$.

O impacto que a estética dentária exerce na atratividade facial foi abordado por inúmeros trabalhos 17,24,75,84,153. Considera-se o posicionamento dentário simétrico um componente importante para um sorriso atraente ${ }^{75,83,84}$, enquanto a assimetria compromete a estética dentária ${ }^{19}$. A coordenação das linhas médias dentárias denota grande importância no plano de tratamento 
ortodôntico e a complexidade de sua correção aumenta com a duração da terapia97. Assim, para a realização de um plano de tratamento adequado, devese avaliar, durante o diagnóstico, as três linhas médias do paciente: a facial, as linhas médias dentárias superior e inferior.

Os resultados deste trabalho indicam que a maior porcentagem da Classe II, subdivisão corresponde ao tipo 1, ou seja, a Classe II se deve ao posicionamento do molar inferior mais para distal com a linha média inferior deslocada para o lado da Classe II, em relação ao plano sagital mediano, em uma face apresentando uma assimetria subclínica38. Neste caso, uma das melhores opções de tratamento consistirá da extração de dois pré-molares superiores e de um pré-molar inferior do lado da Classe 2,29,35,36,40,79,82,97,138,170,174, desde que o perfil do paciente permita certa retração dos incisivos superiores e incisivos inferiores ${ }^{79,138}$. Isto produzirá uma oclusão final com o lado da Classe I terminando em Classe I de molar e de canino, enquanto que no lado da Classe II, o molar terminará em Classe II e o canino em Classe I, com as linhas médias dentárias superior e inferior coincidentes entre si e com o plano sagital mediano. O uso de elásticos intermaxilares torna-se minimizado, já que nesta forma de tratamento, há uma facilidade da correção do desvio da linha média que será obtida concomitantemente com o fechamento do espaço da extração do arco inferior 79,97 .

Uma variação desse padrão de extrações, quando se têm as mesmas características anteriores consiste em extrair também um segundo pré-molar inferior do lado da Classe II, estabelecendo-se uma ancoragem diferencial entre os caninos direito e esquerdo e assim, obtendo a relação de Classe I desses dentes ${ }^{79}$. Desta forma, fecham-se todos os espaços da extração no lado da Classe II pela retração completa dos dentes anteriores superiores e completa mesialização do segmento póstero-inferior para o espaço da extração35,36,79,138,174. Apesar deste segundo esquema de extrações também produzir resultados satisfatórios, requer-se uma maior utilização de elásticos intermaxilares para ajudar na obtenção de uma relação de Classe I, de molar, deste lado. Há uma dificuldade na correção do desvio da linha média, uma vez que, para o fechamento do espaço da extração do pré-molar do lado da Classe II, a linha média deslocar-se-á ainda mais para este lado79,138. Pode-se utilizar, 
nestes casos, um arco retangular no arco superior e um arco redondo no inferior, com amarrações distais associados a um elástico de Classe I e um elástico diagonal anterior, para ajudar na correção da linha média59,79,97. No entanto, esta conduta apresenta um prognóstico mais desfavorável, já que necessita muita colaboração do paciente com relação ao uso de aparelhos extrabucais ou elásticos intermaxilares ${ }^{79}$.

Há casos de pacientes com assimetria subclínica ${ }^{38}$, com as mesmas características anteriores, em que o perfil não permite um esquema de extrações, com retrações subseqüentes. Para tal situação, o tratamento deve almejar a correção ântero-posterior do lado da Classe II, com a utilização de elásticos de Classe II unilaterais ou com elásticos de Classe II e elásticos diagonais anteriores ${ }^{59}$. Porém, a colaboração do paciente torna-se de fundamental importância79. Deve-se ter em mente a dificuldade de realização deste tipo de mecânica unilateral que pode afetar 0 arco superior concomitantemente ${ }^{141}$, como também causar inclinações indesejáveis no plano oclusaR9.

Neste estudo, observourse que a Classe II, subdivisão - tipo 2 ocorre com menor freqüência, caracterizando-se pela tendência de posicionamento mais para mesial do molar superior, com desvio da linha média dentária superior em relação ao plano sagital mediano e coincidência da linha média dentária inferior, em relação a esse plano, em caso sem apinhamento superior ou inferior. Neste tipo, os melhores resultados seriam proporcionados pela extração de apenas um pré-molar superior do lado da Classe II, terminando com uma relação molar de Classe II desse lado, mas com as linhas médias dentárias coincidentes entre si e com o plano sagital mediano. Pode-se optar pela correção com a utilização de forças extrabucais assimétricas nos casos de pacientes em crescimento e que sejam colaboradores, em que o desvio ânteroposterior não seja tão acentuado ${ }^{79}$.

Geralmente, corrigem-se as discrepâncias menores de coordenação de linha média nos estágios finais, com elásticos assimétricos intermaxilares de Classe II e Classe III, associados a um elástico diagonal anterior $3,97,134$. 
Sugestões para futuros trabalhos:

Estudos semelhantes com um número maior de casos no grupo de Classe II, subdivisão - tipo 2. 


\section{Conclusões}




\section{7 - Conclusões}

Baseando-se nos resultados obtidos neste trabalho, de acordo com a metodologia utilizada, conclui-se que:

7.1 - Dentre o grupo de Classe II, subdivisão, 61,36\% constituem-se de Classe II, subdivisão - tipo 1 (linha média superior coincidente e inferior desviada em relação ao plano sagital mediano); 18,18\% de Classe II, subdivisão - tipo 2 (linha média inferior coincidente e superior desviada em relação ao plano sagital mediano) e $20,45 \%$ foram considerados duvidosos.

7.2 - Mesmo se subdividindo um grupo de Classe II, subdivisão em tipos 1 e 2 e comparando-os isoladamente com um grupo de oclusão normal, houve uma presença ínfima de assimetrias esqueléticas estatisticamente significantes, concluindo-se que os principais componentes que contribuem para a relação ântero-posterior assimétrica na Classe II, subdivisão - tipo 1 e na Classe II, subdivisão - tipo 2 são dentoalveolares. 


\section{Referências \\ Bibliográficas}




\section{Referências Bibliográficas*}

1- ADLER, P. A critical account of Grunber's method of symmetroscopy. Dent. Items, v.70, p.433-41, 1948.

2- ALAVI, D. G.; BEGOLE, E. A.; SHNEIDER, B. J. Facial and dental arch asymmetries in Class II subdivision malocclusion. Amer. J. Orthodont. Dentofac. Orthop., v.93, n.1, p.38-46, Jan. 1988.

3- ALEXANDER, R. G. The Alexander discipline. Glendora, CA, ORMCO, 1987.

4- ALMEIDA, R. C.; ALMEIDA, M. H. C. A assimetria facial, no exame clínico da face. Ortodontia, v.32, n.2, p.82-6, Maio-Ago. 1999.

5- ANGLE, E. H. Classification of malocclusion. Dent. Cosmos, v.41, p.24864, 1899.

6- ANGLE, E. H. Malocclusion of the teeth. 7. Philadelphia, S. S. White, 1907.

7- ARNETT, G. W.; BERGMAN, R. T. Facial keys to orthodontic diagnosis and treatment planning: part I. Amer. J. Orthodont. Dentofac. Orthop., v.103, p.299-312, 1993.

8- ARNOLD, T. G.; ANDERSON, G. C.; LIL YEMARK, W. F. Assessment of craniofacial asymmetry with S-V radiographs. Amer. J. Orthodont. Dentofac. Orthop., v.106, n.3, p.250-6, Sept. 1994.

9- AZAZ, B.; NITZAN, D. W.; BRIN, L. Condylar hyperplasia: remodeling of facial structures following condylectomy. Report of two cases. Int. J. Adult Orthodont. Orthognat. Surg., v.6, n.1, p.47-55, JAN. 1991.

\footnotetext{
Normas recomendadas para uso no âmbito da Universidade de São Paulo, com base no documento "Referências Bibliográficas: exemplos", emanado do Conselho Supervisor do Sistema Integrado de Bibliotecas da USP, em reunião de 20 de setembro de 1990.
} 
10- BAKER, W. L. The influence of the forces of occlusion on the development of the bones of the skull. Int. J. Orthodont. Oral Surg. Radiol., v.8, p.259, 1922.

11- BAUMRIND, S.; FRANTZ, R. The reliability of head film measurements. Amer. J. Orthodont., v.60, n.2, p.111-27, Aug. 1971.

12- BEGG, P. R.; KESLING, P. Begg orthodontic theory and technique. 3. Philadelphia, W. B. Saunders, 1977.

13- BEGOLE, E. A. Application of the cubic spline function in the description of dental arch form. J. dent. Res., v.51, p.1549-56, Sep 1980.

14- BERGAMINI, A.; MELSEN, B. Case report: treatment of dental asymmetry. Angle Orthodont., v.65, n.4, p.247-52, July 1995.

15- BERGER, H. Problems and promises of basilar view cephalograms. Angle Orthodont., v.31, n.4, p.237-45, Oct. 1961.

16- BERGER, H. Progress with basilar view cephalograms. Trans. Europ. Orthodont. Soc., v.40, p.159-64, 1964.

17- BEYER, J. W.; LINDAUER, S. Evaluation of dental midline position. Seminars in Orthodontics, v.4, n.3, p.146-52, Sept. 1998.

18- BIGGERSTAFF, R. H. Three variations in dental arch form estimated by a quadratic equation. J. dent. Res., v.51, p.1509, Sep-Oct. 1972.

19- BISHARA, S. E.; BURKEY, P. S.; KHAROUF, J. G. Dental and facial asymmetries: a review. Angle Orthodont., v.64, n.2, p.89-98, Mar. 1994.

20- BJÖRK, A.; BJÖRK, L. Artificial deformation and craniofacial asymmetry in ancient peruvians. J. dent. Res., v.43, n.3, p.353-63, May/June 1964. 
21- BLACKWOOD, H. O. Clinical management of the jasper jumper. J. clin. Orthodont., v.25, n.12, p.755-60, Dec. 1991.

22- BRASH, J. C.; MCKEAG, H. T. A. The aetiology of irregularity and malocclusion of the teeth. Dental Board of U. K. London,1956.

23- BRAUN, S. Achieving improved visualization of the temporomandibular joint condyle and fossa in the sagittal cephalogram and a pilot study of their relationships in habitual occlusion. Amer. J. Orthodont. Dentofac. Orthop., v.109, n.6, p.635-8, June 1996.

24- BRAUN, S.; LEGAN, H. Changes in the occlusion related to the cant of the occlusal plane. Amer. J. Orthodont. Dentofac. Orthop., v.111, n.2, p.184-8, Feb. 1997.

25- BREAKSPEAR, E. K. Some aspects of the retraction of upper incisors by appliances. $38^{\text {th }}$ Congress, European Orthodontic Society. J. Europ. Orthodont. Soc., v.342, 1963.

26- BUCHIN, I. D. JCO Interviews. J. clin. Orthodont., v.1, n.11, p.103-10, Nov. 1967.

27- BURSTONE, C. J. The integumental profile. Amer. J. Orthodont., v.44, n.1, p.1-25, Jan. 1958.

28- BURSTONE, C. J. Lip posture and its significance in treatment planning. Amer. J. Orthodont., v.53, p.262-84, 1967.

29- BURSTONE, C. J. JCO Interviews: On the use of the computer in orthodontic practice (Part 1). J. clin. Orthodont., v.13, n.7, p.442-53, Jul. 1979. 
30- BURSTONE, C. J. Diagnosis and treatment planning of patients with asymmetries. Seminars in Orthodontics, v.4, n.3, p.153-64, Sept. 1998.

31- CAMPBELL, J. The mylohyoid line in the assessment of facial asymmetry. Dent. Rec., v.70, n.9-10, p.204-8, Sept./Oct. 1950.

32- CASSIDY, D. W. et al. A comparison of surgery and orthodontics in "borderline" adults with Class II, division 1 malocclusions. Amer. J. Orthodont. Dentofac. Orthop., v.104, n.5, p.455-70, Nov. 1993.

33- CETLIN, N. M.; TEN HOEVE, A. T. Non extraction treatment. J. clin. Orthodont., v.17, n.6, p.396-404, June 1983.

34- CHEBIB, F. S.; CHAMMA, A. M. Indices of craniofacial asymmetry. Angle Orthodont., v.51, n.3, p.214-26, July 1981.

35- CHENEY, E. A. The influence of dentofacial asymmetries upon treatment procedures. Amer. J. Orthodont., v.38, n.2, p.934-45, July 1952.

36- CHENEY, E. A. Dentofacial asymmetries and their clinical significance. Amer. J. Orthodont., v.47, n.2, p.814-29, Feb. 1961.

37- CLAMAN, L.; PATTON, D.; RASHID, R. Standardized portrait photography for dental patients. Amer. J. Orthodont. Dentofac. Orthop., v.98, n.3, p.197-205, Sept. 1990.

38- COOK, J. T. Asymmetry of the craniofacial skeleton. Brit. J. Orthodont., v.7, n.1, p.33-8, Jan. 1980.

39- COPE, J. B. et al. Quantitative evaluation of craniofacial changes with jasper jumper therapy. Angle Orthodont., v.64, n.2, p.113-22, Mar. 1994. 
40- CRUZ, K. S. Avaliação das alterações dentoesqueléticas decorrentes do tratamento da má oclusão de Classe II, subdivisão por meio das radiografias submentoniana e póstero-anterior. Bauru, 2000. 236p. Mestrado - Faculdade de Odontologia de Bauru, Universidade de São Paulo.

41- CRUZ, K. S. et al. Efeitos dos aparelhos funcionais na correção da má oclusão de Classe II. Rev. Dental Press Ortodon. Ortop. Facial, v.5, n.2, p.1-10, jul./ago. 2000.

42- CZARNECKI, S. T.; NANDA, R. S.; CURRIER, G. F. Perceptions of a balanced facial profile. Amer. J. Orthodont. Dentofac. Orthop., v.104, n.2, p.180-7, Aug. 1993.

43- DAHLBERG, G. Statistical methods for medical and biological students. New York, Intercience, 1940.

44- DAWSON, P. E. Evaluation, diagnosis, and treatment of occlusal problems. St. Louis, C. V. Mosby Co., 1974.

45- EDLER, R.; WERTHEIM, D.; GREENHILL, D. Clinical and computerized assessment of mandibular asymmetry. Europ. J. Orthodont, v.23, n.5, p.485-94, Oct. 2001.

46- ENLOW, D. H. Facial growth. Philadelphia, W. B. Saunders, 1990.

47- ENLOW, D. H.; KURODA, T.; LEWIS, A. B. The morphological and morphogenetic basis for craniofacial form and pattern. Angle Orthodont., v.41, n.3, p.161-88, July 1971.

48- ERDOGAN, E.; ERDOGAN, E. Asymmetric application of the Jasper Jumper in the correction of midline discrepancies. J. clin Orthodont., v.32, n.3, p.170-80, Mar. 1998. 
49- FERGUSON, J. W. Cephalometric interpretation and assessment of facial asymmetry secondary to congenital torticolis. Int. J. oral Maxillofac. Surg., v.22, p.7-10, 1993.

50- FERRARIO, V. F. et al. Craniofacial morphometry by photografic evaluations. Amer. J. Orthodont. Dentofac. Orthop., v.103, n.4, p.327-37, Apr. 1993.

51- FERRARIO, V. F. et al. Distance from symmetry: a three-dimensional evaluation of facial asymmetry. J. oral Maxillofac. Surg., v.52, n.11, p.1126-32, 1994.

52- FIORENTINO, G.; MELSEN, B. Asymmetric mandibular space closure. J. clin. Orthodont., v.30, n.9, p.519-23, Sept. 1996.

53- FISCHER, B. Asymmetries of dentofacial complex. Angle Orthodont., v.24, n.4, p.179-92, Oct. 1954.

54- FORSBERG, C. T.; BURSTONE, C. J.; HANLEY, K. J. Diagnosis and treatment planning of skeletal asymmetry with the submentatvertical radiograph. Amer. J. Orthodont., v.85, n.3, p.224-37, Mar. 1984.

55- FRIEL, S. The diagnosis of malocclusion of the teeth. Dent. Cosmos, v.56, p.825-33, 1914.

56- FUSHIMA, K.; INUI, M.; SATO, S. Dental asymmetry in temporomandibular disorders. J. oral Rehab., v.26, n.9, p.752-6, Sept. 1999.

57- GAVAN, J. A.; WASHBURN, S. L.; LEWIS, P. H. Photography: an anthropometric tool. Amer. J. phys. Anthrop., v.10, p.331-53, 1952.

58- GIANELLY, A. A.; BEDNAR, J.; DIETZ, V. S. Japanese niti coils used to move molars distally. Amer. J. Orthodont. Dentofac. Orthop., v.99, n.6, p.546-66, June 1991. 
59- GiANElly, A. A.; PAUL, I. A. A procedure for midline correction. Amer. J. Orthodont., v.58, n.3, p.264-7, Sept. 1970.

60- GILBERT, D. H. Radiograph method of basilar cephalometrics. Amer. J. Orthodont., v.46, p.384-5, May 1960.

61- GRAVELY, J. F.; BENZIES, P. M. The clinical significance of tracing error in cephalometry. Brit. J. Orthodont., v.1, p.95-101, 1974.

62- GRAYSON, B. H. et al. Basilar multiplane cephalometric analysis. Amer. J. Orthodont., v.88, n.6, p.503-16, Dec. 1985.

63- GRAYSON, B. H.; MCCARTHY, J. G.; BOOKSTEIN, F. An analysis of craniofacial asymmetry by multiplane cephalometry. Amer. J. Orthodont., v.84, n.3, p.217-24, Sept. 1983.

64- GRUMMONS, D. C.; VAN DE COPPELLO, M. A. K. A frontal asymmetry analysis. J. clin. Orthodont., v.21, n.7, p.448-65, July 1987.

65- HABERLE, F. E. A quantitative study of the malocclusion and correction in the posterior segment of the arches of 16 patients. Chicago, 1937. Master's Thesis - Northwestern University.

66- HARVOLD, E. P. The asymmetries of the upper facial skeleton and their morphological significance. Trans. Europ. Orthodont. Soc., p.63-9, 1951.

67- HARVOLD, E. P. A roentgen study of the postnatal morphogenesis of the facial skeleton in cleft palate. Oslo, 1954. Master Thesis Department of Anthropology and Norwegian Dental School, Anatomical Institute, University of Oslo. 
68- HATALA, M. P. et al. Effect of a surgically crested disk displacement on mandibular symmetry in the growing rabbit. Oral Surg., v.82, n.6, p.625-33, Dec. 1996.

69- HECHTER, F. J. Symmetry of the form and dimension of the dental arches of orthodontically treated patients. Winnipeg, 1975. Masters Thesis - University of Manitoba.

70- HENRIQUES, J. F. C. et al. Tratamento da Classe II, 1a divisão com o aparelho regulador funcional de Fränkel (FR). Apresentação de um caso clínico. Rev. Dental Press Ortodon. Ortop. Facial, v.3, n.1, p.2331, jan./fev. 1998.

71- HERSHEY, H.; HOUGHTON, C. W.; BURSTONE, C. J. Unilateral facebows: a theoretical and laboratory analysis. Amer. J. Orthodont., v.79, n.3, p.229-49, Mar. 1981.

72- HERZBERG, B. L. Facial esthetics in relation to orthodontic treatment. Angle Orthodont., v.22, n.1, p.3-22, Jan. 1952.

73- HOLDAWAY, R. A. A soft-tissue cephalometric analysis and its use in orthodontic treatment planning: part I. Amer. J. Orthodont., v.84, p.128, 1983.

74- HOUSTON, W. J. B. The analysis of erros in orthodontic measurements. Amer. J. Orthodont., v.83, n.5, p.382-90, May 1983.

75- HULSEY, C. M. An esthetic evaluation of lip-teeth relationships present in the smile. Amer. J. Orthodont., v.57, n.2, p.132-43, Feb. 1970.

76- ISBERG, A. M.; ELIASSON, S. A cephalometric analysis of patients with coronoid process enlargement and locking. Amer. J. Orthodont. Dentofac. Orthop., v.97, n.1, p.35-40, Jan. 1990. 
77- ISBERG, A. M. et al. Coronoid process elongation in rhesus monkeys (Macaca mulatta) after experimentally induced mandibular hypomobility: a cephalometric and histologic study. Oral Surg., v.70, n.6, p.704-10, Dec. 1990.

78- JACKSON, A. F. Facts, fictions and fallacies in orthodontics. Amer. J. Orthodont. oral Surg., v.23, p.1073-95, 1937.

79- JANSON, G. R. P. Estudo tridimensional das assimetrias dentárias e esqueléticas na má oclusão de Classe II, subdivisão. Bauru, 1998. 271p. Livre-Docência - Faculdade de Odontologia de Bauru, Universidade de São Paulo.

80- JANSON, G. R. P.; METAXAS, A.; WOODSIDE, D. G. Variation in maxillary and mandibular molar and incisor vertical dimension in 12year-old subjects with excess, normal and short lower anterior face height. Amer. J. Orthodont. Dentofac. Orthop., v.106, n.4, p.409-18, Oct. 1994.

81- JANSON, G. R. P. et al. Three-dimensional evaluation of skeletal and dental asymmetries in Class II subdivision malocclusions. Amer. J. Orthodont. Dentofac. Orthop., v.119, n.4, p.406-18, 2001.

82- JANSON, G. R. P. et al. A assimetria dentária e suas implicações no tratamento ortodôntico: Apresentação de um caso clínico. Ortodontia, v.28, n.3, p.68-73, 1995.

83- JERROLD, L.; LOWENSTEIN, L. J. The midline: diagnosis and treatment. Amer. J. Orthodont. Dentofac. Orthop., v.97, n.6, p.453-62, June 1990.

84- JOHNSTON, C. D.; J., B. D.; STEVENSON, M. R. The influence of dental to facial midline discrepancies on dental attractiveness ratings. Europ. J. Orthodont., v.21, n.5, p.517-22, Oct. 1999. 
85- KAHL-NIEKE, B.; FISCHBACH, R. Effect of early orthopedic intervention on hemifacial microssomia patients: an approach to a cooperative evaluation of treatment results. Amer. J. Orthodont. Dentofac. Orthop., v.114, n.5, p.538-57, Nov. 1998.

86- KANTOMAA, T. The relation between mandibular configuration and the shape of the glenoid fossa in the human. Europ. J. Orthodont., v.11, p.77-81, 1989.

87- KONDO, E.; AOBA, T. Case report of malocclusion with abnormal head posture and TMJ symptoms. Amer. J. Orthodont. Dentofac. Orthop., v.116, n.5, p.481-93, Nov. 1999.

88- KROGMAN, W. M.; SASSOUNI, V. Syllabus in roentgenographic cephalometry. Philadelphia Center for Research in Child Growth. Philadelphia, 1957

89- KRONMILLER, J. E. Development of asymmetries. Seminars in Orthodontics, v.4, n.3, p.134-7, Sept. 1998.

90- KULA, K.; ESMAILNEJAD, A.; HASS, A. Dental arch asymmetry in children with large overjets. Angle Orthodont., v.68, n.1, p.45-62, Feb. 1998.

91- LAM, P. H.; SADOWSKY, C.; OMERZA, F. Mandibular asymmetry and condilar position in children with unilateral posterior crossbites. Amer. J. Orthodont. Dentofac. Orthop., v.115, n.5, p.569-76, May 1999.

92- LEGAN, H. L. Surgical correction of patients with asymmetries. Seminars in Orthodontics, v.4, n.3, p.189-98, Sept. 1998.

93- LEGAN, H. L.; BURSTONE, C. J. Soft tissue cephalometric analysis for orthognahic surgery. Oral Surg., v.38, p.744-51, 1980. 
94- LEGRELL, P. E.; ISBERG, A. Mandibular length and midline asymmetry after experimentally induced temporomandibular joint disk displacement in rabbits. Amer. J. Orthodont. Dentofac. Orthop., v.115, n.3, p.24753, Mar. 1999.

95- LETZER, G. M.; KRONMAN, J. H. A posterior cephalometric evaluation of craniofacial asymmetry. Angle Orthodont., v.37, n.3, p.205-11, July 1967.

96- LEW, K. K. K.; TAY, D. K. L. Submentovertex cephalometric norms in male chinese subjects. Amer. J. Orthodont. Dentofac. Orthop., v.103, n.3, p.247-52, Mar. 1993.

97- LEWIS, D. The deviated midline. Amer. J. Orthodont., v.70, n.6, p.60116, Dec. 1976.

98- LINDAUER, S. J. Introduction. Seminars in Orthodontics, v.4, n.3, p.133, Sept. 1998.

99- LIVIERATOS, F. A.; JOHNSTON, L. E. A comparison of one-stage and two-stage nonextraction alternatives in matched Class II samples. Amer. J. Orthodont. Dentofac. Orthop., v.108, n.2, p.118-31, Aug. 1995.

100- LUDWIG, W. Rechts-links-problem im Tierreich und beim menschen. 1932. Monograph - Physiol. Pfl. Tiere apud LUDSTRÖM, A. p.84.

101- LUNDSTRÖM, A. Some asymmetries of the dental arches, jaws, and skull, and their etiological significance. Amer. J. Orthodont., v.47, n.2, p.81-106, Feb. 1961.

102- MANDURINO, M.; BALDUCCI, L. Asymmetric distalization with a TMA transpalatal arch. J. clin. Orthodont., v.35, n.3, p.174-8, Mar. 2001. 
103- MARMARY, Y.; ZILBERMAN, Y.; MIRSKY, Y. Use of foramina spinosa to determine skull midlines. Angle Orthodont., v.49, n.4, p.263-8, Apr. 1979.

104- MARTINS DE ARAÚJO, T.; SCHIRMER, R. W.; ALMEIDA, M. A. Skeletal and dental arch asymmetries in Class II, division 1, subdivision malocclusions. J. clin. pediat. Dent., v.18, n.3, p.181-5, June 1994.

105- MCNAMARA JUNIOR, J. A. Components of Class II malocclusion in children 8-10 years of age. Angle Orthodont., v.51, n.3, p.177-202, July 1981.

106- MELNIK, A. K. A cephalometric study of mandibular asymmetry in a longitudinally followed sample of growing children. Amer. J. Orthodont. Dentofac. Orthop., v.101, n.4, p.355-66, Apr. 1992.

107- MELSEN, B. Asymmetric development of the cranio-facial skeleton: etiology, pathogenesis and treatment. In: INTERNATIONAL SYMPOSIUM ON FEEDING AND DENTOFACIAL DEVELOPMENT 2., Chicago, 1988. Proceedings. Chicago, 1988. p.37.

108- MELSEN, B.; BJERREGAARD, J.; BUNDGAARD, M. The effect of treatment with functional appliances on a pathologic growth pattern of the condyle. Amer. J. Orthodont. Dentofac. Orthop., v.90, n.6, p.503-12, Dec. 1986.

109- MERRILL, V. Atlas of roentgenographic positions. Saint Louis, C. V. Mosby, 1949.

110- MIZUNO, A.; MOTEGI, K. Treatment of an asymmetric mandibular prognathism in an acromegalic patient. J. oral Maxillofac. Surg., v.46, n.4, p.314-20, Apr. 1988. 
111- MONGINI, F. Remodelling of the temporomandibular condyle in the adult and its relationship to the conditions of the dental arches. Acta anat., v.82, p.292-300, 1972.

112- MONGINI, F.; SCHMID, W. Treatment of mandibular asymmetries during growth: a longitudinal study. Europ. J. Orthodont., v.9, n.1, p.51-67, Feb. 1987.

113- MOORE, G. R.; HUGHES, B. O. Familial factors in diagnosis, treatment and prognosis of dentofacial disturbancies. Amer. J. Orthodont., v.28, n.10, p.603-39, Oct. 1942.

114- MOSS, M. I.; SALENTIJN, I. Differences between the functional matrices in the anterior open bite and in deep overbite. Amer. J. Orthodont., v.60, n.6, p.264-80, Sept. 1971.

115- MOYERS, R. E. et al. Differential diagnosis of Class II malocclusion (Part 1). Facial types associated with Class II malocclusions. Amer. J. Orthodont., v.78, n.5, p.477-94, Nov. 1980.

116- MULICK, J. F. An investigation of craniofacial asymmetry using the serial twin study method. Amer. J. Orthodont. Dentofac. Orthop., v.51, n.2, p.112-29, Feb. 1965.

117- NAHOUM, H. I.; FIASCONARO, J.; DI SALVO, N. A. The verticosubmental roentgenogram in cephalometrics. J. Amer. dent. Ass., v.69, p.133-50, Aug. 1964.

118- O'BYRN, B. L. et al. An evaluation of mandibular asymmetry in adults with unilateral posterior crossbite. Amer. J. Orthodont. Dentofac. Orthop., v.107, n.4, p.394-400, Apr. 1995. 
119- OGAARD, B.; KROGSTAD, O. Craniofacial structure and soft tissue profile in patients with severe hypodontia. Amer. J. Orthodont. Dentofac. Orthop., v.108, n.5, p.472-7, Nov. 1995.

120- OKESON, J. P. Management of temporomandibular disorders and occlusion. 2. St. Louis, C. V. Mosby, 1989.

121- O'REILLY, B. L.; NANDA, S. K.; CLOSE, J. Cervical and oblique headgear: a comparison of treatment effects. Amer. J. Orthodont. Dentofac. Orthop., v.103, n.6, p.504-9, June 1993.

122- OSBORNE, R. The treatment of the underdeveloped ascending ramus. Brit. J. plast. Surg., v.17, p.376-88, 1964.

123- PANCHERZ, $\mathrm{H}$. The nature of Class II relapse after Herbest appliance treatment: a cephalometric long-term investigation. Amer. J. Orthodont. Dentofac. Orthop., v.100, n.3, p.220-33, Sept. 1991.

124- PARK, Y. C.; BURSTONE, C. J. Soft-tissue profile: fallacies of hard-tissue standards in treatment planning. Amer. J. Orthodont. Dentofac. Orthop., v.90, n.1, p.52-62, July 1986.

125- PEARSON, K.; WOO, T. L. Further investigation of the morphometric characters of individual bones of the human skull. Biometrika, v.2, p.242-65, 1935.

126- PECK, S.; PECK, L.; KATAJA, M. Skeletal asymmetry in esthetically pleasing faces. Angle Orthodont., v.61, n.1, p.43-8, Spring 1991.

127- PEPE, S. H. Polynomial and catenary curve fits to human dental arches. J. dent. Res., v.54, p.1124-32, Nov-Dec. 1975. 
128- PINTO, A. S. et al. Morphological and positional asymmetries of young children with functional unilateral posterior crossbite. Amer. J. Orthodont. Dentofac. Orthop., v.120, n.5, p.513-20, Nov. 2001.

129- PIRTTINIEMI, P. Normal and increased functional asymmetries in the craniofacial area. Acta odont. scand., v.56, n.6, p.342-5, Dec. 1998.

130- PIRTTINIEMI, P.; KANTOMAA, T. Relation of glenoid fossa morphology to mandibulofacial asymmetry, studied in dry human Lapp skulls. Acta odont. scand., v.50, n.4, p.235-43, Aug. 1992.

131- PIRTTINIEMI, P.; KANTOMAA, T.; RONNING, O. Relation of glenoid fossa to craniofacial morphology, studied on dry human skulls. Acta odont. scand., v.48, n.6, p.359-64, Nov. 1990.

132- POLLARD, L. E.; MAMANDRAS, A. H. Male postpubertal facial growth in Class II malocclusions. Amer. J. Orthodont. Dentofac. Orthop., v.108, n.1, p.62-8, July 1995.

133- PONYI, S.; SZABÓ, G.; NYILASI, J. Asymmetry of mandibular dimensions in european skulls. Proc. Fin. dent. Soc., v.87, n.3, p.321-7, July 1991.

134- PROFFIT, W. R. Contemporary Orthodontics. Saint Louis, C. V. Mosby, 1986.

135- PROFFIT, W. R.; TURVEY, T. Augmentation genioplasty as an adjunct to conservative orthodontic treatment. Amer. J. Orthodont., v.79, n.5, p.473-91, May 1981.

136- PROFFIT, W. R.; VIG, K. W. L.; TURVEY, T. A. Early fracture of the mandibular condyles: frequently and unsuspected cause of growth disturbances. Amer. J. Orthodont., v.78, n.1, p.1-24, July 1980. 
137- PULLINGER, A. G. et al. Relationship of mandibular condylar position to dental occlusion factors in an asymptomatic population. Amer. J. Orthodont. Dentofac. Orthop., v.91, n.3, p.200-6, Mar. 1987.

138- REBELLATO, J. Asymmetric extractions used in the treatment of patients with asymmetries. Seminars in Orthodontics, v.4, n.3, p.180-8, Sept. 1998.

139- RICHARDSON, A. A comparison of traditional and computadorized method of cephalometric analysis. Europ. J. Orthodont., v.3, p.1520, 1981.

140- RITUCCI, R.; BURSTONE, C. J. Use of the submental vertical radiograph in the assessment of asymmetry. Farmington, 1981. Certificate in Orthodontics - Department of Orthodontics, University of Connecticut.

141- ROSE, J. M. et al. Mandibular skeletal and dental asymmetry in Class II subdivision malocclusions. Amer. J. Orthodont. Dentofac. Orthop., v.105, n.5, p.489-95, May 1994.

142- ROSEN, M. D.; BUTCHER, E. O.; SILVERMAN, S. I Muscle and skull development changes in dogs with induced unilateral anodontia. Oral Surg., v.3, p.672-5, Nov. 1965.

143- ROTH, R. H. Functional occlusion for the orthodontist. Part 1. J. clin. Orthodont., v.15, n.1, p.32-51, Jan. 1981.

144- SARNAS, K. V. et al. Hemifacial microsomia treated with the Herbst appliance: report of a case analysed by means of roentgen stereometry and metallic implants. Amer. J. Orthodont., v.82, n.1, p.68-74, July 1982. 
145- SASSOUNI, V. Position of the maxillary permanent first molar in the cephalofacial complex: a study in three dimensions. Amer. J. Orthodont., v.43, n.7, p.447-510, July 1957.

146- SCAVONE JÚNIOR, H. O perfil facial tegumentar dos 13 aos 18 anos de idade: estudo cefalométrico longitudinal em jovens brasileiros leucodermas, com oclusão normal. Bauru, 1996. 217p. Doutorado - Faculdade de Odontologia de Bauru, Universidade de São Paulo.

147- SCHEIDEMAN, G. B. et al. Cephalometric analysis of dentofacial normals. Amer. J. Orthodont., v.78, n.4, p.404-20, Oct. 1980.

148- SCHELLHAS, K. P.; POLLEI, S. R.; WILKES, C. H. Pediatric internal derangements of the temporomandibular joint: effect on facial development. Amer. J. Orthodont. Dentofac. Orthop., v.104, n.1, p.51-9, July 1993.

149- SCHMID, W.; MONGINI, F.; FELISIO, A. A computer-based assessment of structural and displacement asymmetries of the mandible. Amer. J. Orthodont. Dentofac. Orthop., v.100, n.1, p.19-34, July 1991.

150- SCHUDY, F. F. Treatment of adult midline deviation by condilar repositioning. J. clin. Orthodont., v.30, n.6, p.343-7, June 1996.

151- SCHUELLER, A. Die Schaedelbasis in Roentgenbild. Fortschr. Geb. Roentgenstr., v.11, 1905 apud JANSON, G. P. R. p.58.

152- SHAH, S. M.; JOSHI, M. R. An assessment of asymmetry in the normal craniofacial complex. Angle Orthodont., v.48, n.2, p.141-7, Apr. 1978. 
153- SHAW, W. C. et al. The influence of dentofacial appearance on the social attractiveness of young adults. Amer. J. Orthodont., v.87, n.1, p.216, Jan. 1985.

154- SHEATS, R. D. et al. Prevalence of orthodontic asymmetries. Seminars in Orthodontics, v.4, n.3, p.138-45, Sept. 1998.

155- SHELLEY, A. et al. Asymmetric extraction treatment of an Angle Class II division 2 subdivision left malocclusion with anterior and posterior crossbites. Amer. J. Orthodont. Dentofac. Orthop., v.118, n.4, p.462-6, Oct. 2000.

156- SHORE, I. L. A cephalometric study of facial symmetry. Pittsburgh, 1959. Master's Thesis - University of Pittsburgh.

157- SHROFF, B.; LINDAUER, S. J.; BURSTONE, C. J. Class II subdivison treatment with tip-back moments. Europ. J. Orthodont., v.19, n.1, p.93-101, Feb. 1997.

158- SHROFF, B. et al. Segmented approach to simultaneous intrusion and space closure: biomechanics of the three-piece base arch appliance. Amer. J. Orthodont. Dentofac. Orthop., v.107, n.2, p.136-43, Feb. 1995.

159- SHROFF, B.; SIEGEL, S. M. Treatment of patients with asymmetries using asymmetric mechanics. Seminars in Orthodontics, v.4, n.3, p.165-79, Sept. 1998.

160- SINCLAIR, P. M. The reader's corner. J. clin. Orthodont., v.27, n.4, p.221-3, Apr. 1993.

161- SJURSEN, R. C.; LEGAN, H. L.; WERTHER, J. R. Case report: assessment, documentation and treatment of a development facial asymmetry following early childhood injury. Angle Orthodont., v.69, n.1, p.89-94, Feb. 1999. 
162- SKINAZI, G. L. S. Unilaterally reinforced facebow for asymmetrical correction. J. clin. Orthodont., v.35, n.5, p.300-3, May 2001.

163- SKOLNICK, J. et al. Prepubertal trauma and mandibular asymmetry in orthognathic surgery and orthodontic patients. Amer. J. Orthodont. Dentofac. Orthop., v.105, n.1, p.73-7, Jan. 1994.

164- SLAVICEK, R. JCO Interviews: on clinical and instrumental functional analysis for diagnosis and treatment planning (Part 1). J. clin. Orthodont., v.22, n.6, p.358-70, June 1988.

165- STAGGERS, J. A. Vertical changes folowing first premolar extractions. Amer. J. Orthodont. Dentofac. Orthop., v.105, n.1, p.19-24, Jan. 1994.

166- SUTTON, P. R. N. Lateral facial asymmetry - methods of assessment. Angle Orthodont., v.38, n.1, p.82-92, Jan. 1968.

167- SVED, A. An analysis of the most important diagnostic methods used in orthodontia. Angle Orthodont., v.1, p.139-60, 1931.

168- TALLENTS, R. H. et al. Angular and Inear comparisons with unilateral mandibular asymmetry. J. craniomandibular dis. fac. oral pain, v.5, n.2, p.135-42, May 1991.

169- TERRY, H. K. The labiolingual appliance. Amer. J. Orthodont., v.55, n.168-87, 1969.

170- TODD, M. et al. Asymmetric extraction treatment of a Class II division 1 subdivision left malocclusion with anterior and posterior crossbites. Amer. J. Orthodont. Dentofac. Orthop., v.115, n.4, p.410-7, Apr. 1999. 
171- UNITED STATES DEPARTMENT OF HEALTH EDUCATION AND WELFARE. An assessment of the occlusion of the teeth of youths 12-17 years. Rockville, Maryland, United States. National Center for Health Statistics, 1977.

172- VIG, P. S.; HEWITT, A. B. Asymmetry of the human facial skeleton. Angle Orthodont., v.45, n.2, p.125-9, Apr. 1975.

173- WARREN, D. W. Subdivision malocclusions: cracking the riddle. J. clin. Orthodont., v.35, n.2, p.93-9, Feb. 2001.

174- WERTZ, R. A. Diagnosis and treatment planning of unilateral Class II malocclusion. Angle Orthodont., v.45, n.2, p.85-94, Apr. 1975.

175- WESTESSON, P. L. et al. Radiographic assessment of asymmetry of the mandible. Amer. J. Neuroradiol., v.15, n.5, p.991-9, May 1994.

176- WHITE, J. C. A study of craniofacial asymmetry. Cleveland, 1982. Case Western University.

177- WILKINSON, L. et al. Systat for windows: statistics. 5. ed. Evanston II, 1992. p.750.

178- WILLIAMSON, E. H. JCO interviews: on occlusion and TMJ dysfunction (Part 1). J. clin. Orthodont., v.15, n.5, p.333-50, May 1981.

179- WILLIAMSON, E. H.; SIMMONS, M. D. Mandibular asymmetry and its relation to pain dysfunction. Amer. J. Orthodont., v.76, n.6, p.612-17, Dec. 1979.

180- WILLIAMSON, E. H.; WILSON, C. W. Use of a submentatvertex analysis for producing quality temporomandibular joint laminagraphs. Amer. J. Orthodont. Dentofac. Orthop., v.70, n.2, p.200-7, Aug. 1976. 
181- WOHL, T. S.; BAMONTE, E.; PEARSON, H. E. Nonextraction treatment of unilateral Class II, division 1 malocclusion with asymmetric headgear. Amer. J. Orthodont. Dentofac. Orthop., v.113, n.5, p.4837, May 1998.

182- WOO, T. L. On the asymmetry of the human skull. Biometrika, v.22, p.324-41, 1931.

183- YAMASHIRO, T.; OKADA, T.; TAKADA, K. Case report: facial asymmetry and early condylar fracture. Angle Orthodont., v.68, n.1, p.85-90, Feb. 1998. 
Abstract 


\section{ABSTRACT}

The primary objective of this study was to determine, by means of frontal photographic evaluation, the distribution of the two main types of Class II subdivision malocclusions. Secondarily, a comparison of the degree of dentoskeletal asymmetries in these two types was performed with a group of normal occlusion using submentovertex and posteroanterior radiographs. The experimental group consisted of 44 untreated Class II subdivision malocclusion subjects with a mean age of 15.3 years. The control group consisted of 30 subjects with normal occlusion with a mean age of 22.42 years. All possessed a full complement of permanent teeth up to the first molars and had not been submitted to orthodontic treatment. Type I Class II subdivision malocclusion presents a coincidence of the maxillary dental midline with the facial midline and a deviation of the mandibular midline. Type II presents the opposite characteristics. Evaluation of the frontal photographs was performed by means of a subjective evaluation by two examiners. In the submentovertex and posteroanterior radiographs, symmetry was assessed by measuring the relative difference in spatial position of dentoskeletal landmarks between right and left sides. Independent $t$ tests were used to compare the dentoskeletal asymmetries of Types I and II with the normal occlusion group. Results demonstrated that $61.36 \%$ presented a Type I, $18.18 \%$ presented a Type II Class II subdivision malocclusion and $20.45 \%$ were considered undefined. The two subgroups of Class II subdivision malocclusion presented a similar degree of skeletal asymmetry as the normal occlusion group. Therefore, it was concluded that the primary contributors for the asymmetric anteroposterior relationship in types 1 and 2 of Class II subdivision malocclusions are dentoalveolar. 
Apêndices 


\section{APÊNDICES}

Os dados apresentados a seguir se referem aos 14 indivíduos de Classe II, subdivisão, selecionados para esta pesquisa. As características dos 30 indivíduos de Oclusão normal e dos 30 indivíduos de Classe II, subdivisão, bem como os valores reais individuais de cada variável, para cada jovem encontram-se nos Apêndices da pesquisa de JANSON79.

Tabela A - 1 - Características dos pacientes dos 14 novos pacientes do grupo de Classe II, subdivisão

\begin{tabular}{lccccc}
\hline Nome paciente & DN & Data Rx & Idade & Direito & Esquerdo \\
1- B. E. & $03 / 09 / 1986$ & $10 / 06 / 2002$ & 15,75 & Classe II & Classe I \\
2- E. S. & $07 / 09 / 1988$ & $01 / 02 / 2002$ & 13,41 & Classe II & Classe I \\
3- G.T. & $20 / 06 / 1988$ & $11 / 03 / 2002$ & 13,75 & Classe I & Classe II \\
4- G. C. & $08 / 07 / 1988$ & $01 / 02 / 2002$ & 13,58 & Classe I & Classe II \\
5- I. C. & $19 / 05 / 1987$ & $05 / 02 / 2002$ & 14,75 & Classe I & Classe II \\
6- J. O. & $22 / 10 / 1989$ & $04 / 02 / 2002$ & 12,33 & Classe I & Classe II \\
7- L. S. & $02 / 09 / 1989$ & $01 / 02 / 2002$ & 12,41 & Classe II & Classe I \\
8- L. C. F. & $06 / 04 / 1988$ & $29 / 04 / 2002$ & 14 & Classe I & Classe II \\
9- M. O. & $11 / 11 / 1986$ & $05 / 02 / 2002$ & 15,25 & Classe I & Classe II \\
10- R. Z. & $27 / 12 / 1981$ & $22 / 04 / 2002$ & 20,33 & Classe I & Classe II \\
11- R. S. & $17 / 12 / 1986$ & $01 / 02 / 2002$ & 15,16 & Classe II & Classe I \\
12- T. D. & $28 / 03 / 1988$ & $18 / 02 / 2002$ & 13,91 & Classe II & Classe I \\
13- V. F. & $27 / 05 / 1989$ & $05 / 02 / 2002$ & 12,75 & Classe II & Classe I \\
14- W. S. & $21 / 10 / 1989$ & $05 / 02 / 2002$ & 12,33 & Classe II & Classe I \\
\hline
\end{tabular}


As tabelas A2 a A-7 se referem aos valores reais individuais de cada variável, para cada paciente, dos 14 novos pacientes do grupo de Classe II, subdivisão

Tabela A - 2

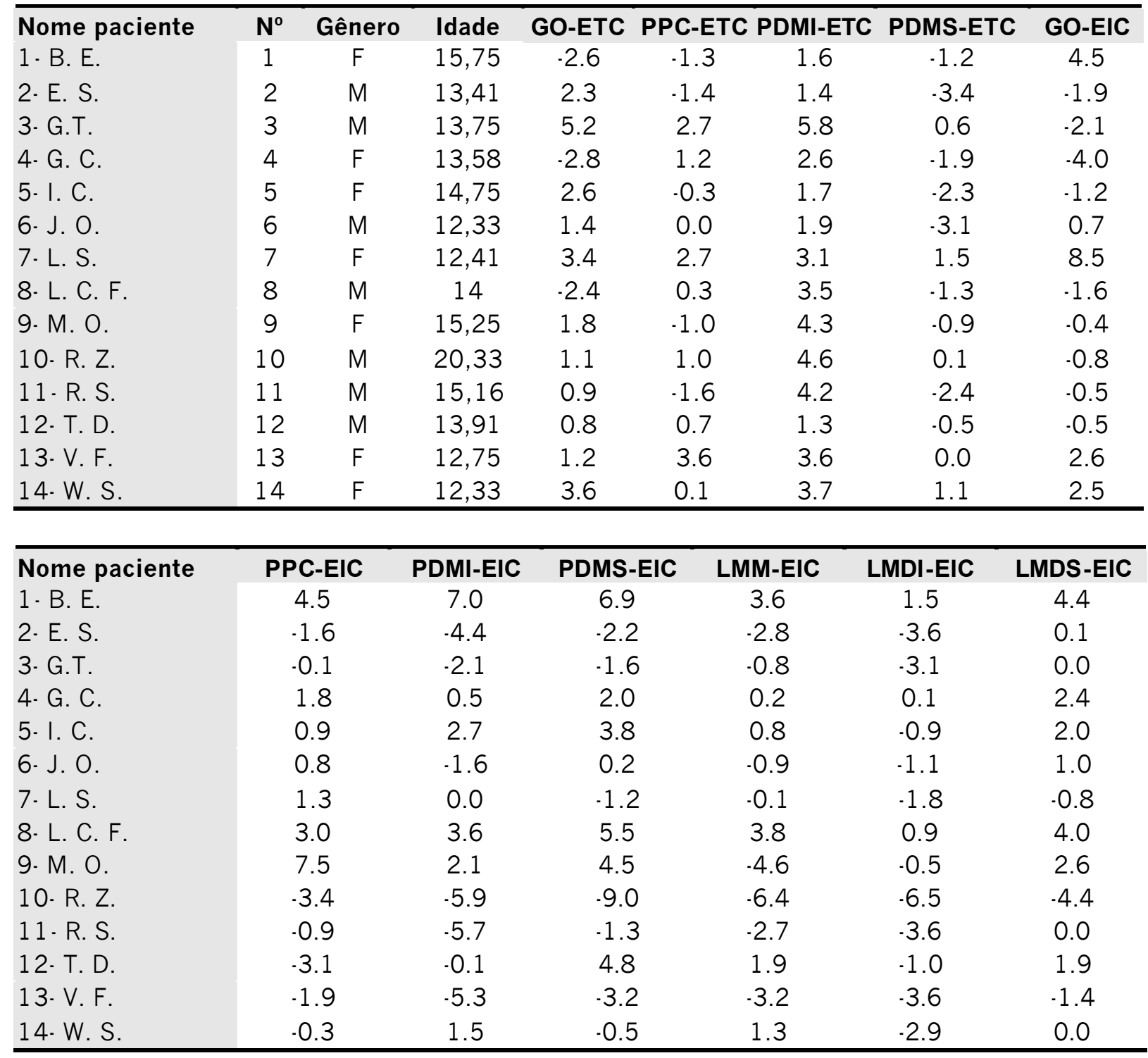


Tabela A - 3

\begin{tabular}{|c|c|c|c|c|c|c|}
\hline Nome paciente & PCM-ETE & GO-ETE & PPC-ETE & PDMI-ETE & PDMS-ETE & ACP-ETE \\
\hline 1-B. E. & .0 .2 & -2.4 & -1.1 & 1.7 & -1.1 & 0.6 \\
\hline 2. E. S. & -0.3 & 2.5 & -1.2 & 1.5 & -3.3 & -1.2 \\
\hline 3. G.T. & 0.8 & 4.4 & 2.0 & 5.4 & 0.2 & 1.5 \\
\hline 4. G. C. & -0.4 & -2.3 & 1.6 & 2.8 & -1.7 & -0.9 \\
\hline 5. I. C. & -3.1 & 5.4 & 2.5 & 3.2 & .0 .8 & -1.0 \\
\hline 6. J. O. & -2.1 & 3.4 & 2.0 & 2.9 & -2.0 & 0.2 \\
\hline 7. L. S. & 0.3 & 3.2 & 2.5 & 2.9 & 1.4 & -0.4 \\
\hline 8. L. C. F. & .0 .9 & -1.6 & 1.1 & 3.9 & .0 .8 & 0.1 \\
\hline 9. М. O. & -1.9 & 3.6 & 0.6 & 5.3 & 0.1 & 1.2 \\
\hline 10. R. Z. & -1.1 & 2.2 & 2.1 & 5.2 & 0.7 & -0.7 \\
\hline 11 - R. S. & 0.9 & 0.0 & -2.4 & 3.7 & -2.9 & 0.7 \\
\hline 12. T. D. & -2.2 & 2.7 & 2.7 & 2.5 & 0.6 & 1.6 \\
\hline 13. V. F. & -2.0 & 2.9 & 5.2 & 4.5 & 0.9 & -0.9 \\
\hline 14- W. S. & 1.6 & 2.1 & -1.4 & 2.8 & 0.2 & -1.0 \\
\hline Nome paciente & FCM-ETE & PCM-EIE & GO-EIE & PPC-EIE & PDMI-EIE & PDMS-EIE \\
\hline 1. B. E. & -3.1 & .0 .4 & 3.9 & 3.6 & 6.1 & 6.0 \\
\hline 2. E. S. & -1.7 & .0 .1 & -2.3 & -2.1 & .4 .9 & -2.7 \\
\hline 3. G.T. & 0.7 & 0.3 & -2.3 & 0.0 & -2.0 & -1.5 \\
\hline 4. G. C. & -1.1 & 3.0 & -1.5 & 4.1 & 2.6 & 4.1 \\
\hline 5. I. C. & 3.1 & 0.6 & -1.3 & 0.1 & 1.6 & 2.7 \\
\hline 6. J. O. & 2.1 & 1.4 & 1.7 & 0.6 & -2.3 & -0.5 \\
\hline 7. L. S. & -1.3 & 0.7 & 9.5 & 3.1 & 2.3 & 1.0 \\
\hline 8. L. C. F. & -0.5 & 1.4 & .0 .5 & 2.7 & 3.0 & 4.8 \\
\hline 9. M. O. & 0.4 & -4.0 & .4 .1 & 2.3 & .3 .4 & -1.0 \\
\hline 10- R. Z. & 0.8 & 0.5 & -1.3 & .5 .1 & -8.3 & -11.4 \\
\hline 11 - R. S. & -6.1 & 3.5 & 3.6 & 3.9 & -0.7 & 3.7 \\
\hline 12. T. D. & 0.3 & .0 .6 & 0.6 & -3.8 & -1.4 & 3.5 \\
\hline 13. V. F. & -0.1 & .0 .1 & 2.4 & -3.6 & .7 .4 & -5.4 \\
\hline 14. W. S. & .2 .9 & 0.5 & 3.0 & 1.9 & 4.0 & 2.2 \\
\hline Nome paciente & LMM-EIE & LMDI-EIE & LMDS-EIE & ACP-EIE & FCM-EIE & BA-EIE \\
\hline 1- B. E. & 3.0 & 0.9 & 3.9 & -3.2 & 1.9 & 1.0 \\
\hline 2. E. S. & .3 .1 & .3 .9 & -0.2 & 0.3 & 4.1 & -0.5 \\
\hline 3. G.T. & .0 .6 & -3.0 & 0.2 & -1.3 & 0.0 & -1.5 \\
\hline 4. G. C. & 1.1 & 1.0 & 3.3 & 3.8 & 10.0 & -1.6 \\
\hline 5. I. C. & -0.1 & -1.9 & 1.0 & 1.3 & -3.9 & 1.9 \\
\hline 6. J. 0. & -1.8 & -2.1 & -0.2 & 2.4 & -2.4 & 0.2 \\
\hline 7. L. S. & 1.5 & .0 .3 & 0.8 & .8 .9 & -4.2 & 1.7 \\
\hline 8. L. C. F. & 2.9 & 0.0 & 3.0 & -4.0 & 3.5 & -3.8 \\
\hline 9. М. O. & .7 .9 & -3.9 & .0 .9 & -3.6 & -1.4 & -4.4 \\
\hline 10. R. Z. & .8 .1 & .8 .2 & -6.2 & 0.9 & -0.9 & -3.6 \\
\hline 11 - R. S. & 0.1 & -0.8 & 3.0 & 1.6 & 7.8 & 1.5 \\
\hline 12. T. D. & 0.6 & -2.6 & 0.3 & .6 .5 & -3.2 & -0.4 \\
\hline 13. V.F. & .4 .9 & -5.4 & .3 .4 & 3.2 & 1.4 & 0.0 \\
\hline 14. W. S. & 3.4 & -0.7 & 2.5 & .4 .4 & 3.1 & .3 .3 \\
\hline
\end{tabular}




\section{Tabela A - 4}

\begin{tabular}{|c|c|c|c|c|c|c|}
\hline Nome paciente & Op-EIE & BC-ETPTM & Z-ETPTM & ACA-ETPTM & A-ETPTM & BC-EIPTM \\
\hline $1 \cdot$ B. E. & 0.6 & -0.2 & 0.8 & 0.7 & -0.6 & -1.8 \\
\hline 2. E. S. & 0.7 & 7.1 & -1.4 & -1.3 & 8.4 & -1.3 \\
\hline 3. G.T. & -1.3 & 0.2 & 1.5 & 1.6 & 0.6 & 1.2 \\
\hline 4. G. C. & -3.6 & -5.5 & -2.1 & -1.9 & -5.3 & 4.6 \\
\hline 5. I. C. & 1.8 & -3.8 & 1.9 & 1.4 & .3 .9 & 1.6 \\
\hline 6. J. O. & 0.9 & 0.1 & 1.2 & 1.2 & 1.0 & 0.7 \\
\hline 7. L. S. & 2.0 & -4.7 & 1.0 & 0.7 & -5.2 & -2.2 \\
\hline 8. L. C. F. & -5.4 & 6.0 & -1.8 & -1.9 & 5.6 & 3.1 \\
\hline 9. М. O. & -4.7 & -1.5 & 0.6 & 0.3 & -0.9 & 2.4 \\
\hline 10. R. Z. & -2.9 & -2.4 & -1.7 & -1.4 & 0.1 & 1.2 \\
\hline 11 - R. S. & 1.5 & 2.2 & .0 .2 & 0.5 & 3.0 & -3.1 \\
\hline 12. T. D. & 2.0 & 0.1 & 1.4 & 1.2 & -1.7 & -0.9 \\
\hline 13. V. F. & 0.7 & -2.5 & 0.6 & 0.4 & -1.7 & 3.0 \\
\hline 14- W. S. & -3.8 & .4 .4 & -0.2 & -0.3 & -4.7 & $\cdot 2.7$ \\
\hline Nome paciente & Z-EIPTM & $\begin{array}{l}\text { ACA- } \\
\text { EIPTM }\end{array}$ & A-EIPTM & VA-EIPTM & VP-EIPTM & LMDS-EIPTM \\
\hline 1. B. E. & -1.7 & -3.5 & -3.5 & -0.3 & -1.0 & 2.7 \\
\hline 2. E. S. & 4.0 & 3.2 & .5 .0 & .2 .1 & -0.1 & -4.2 \\
\hline 3. G.T. & 0.0 & 2.7 & 0.0 & 1.4 & .0 .6 & -1.0 \\
\hline 4. G. C. & 1.1 & 6.6 & 6.7 & 4.5 & 0.1 & 1.3 \\
\hline 5. I. C. & -2.0 & -5.1 & 1.5 & 1.8 & 0.0 & 3.7 \\
\hline 6. J. O. & -0.7 & .0 .3 & -0.4 & -0.3 & 1.1 & 0.1 \\
\hline 7. L. S. & .5 .8 & -11.3 & -1.0 & 1.5 & 0.5 & 3.3 \\
\hline 8. L. C. F. & 4.3 & 5.9 & 1.0 & 1.0 & 2.1 & -0.3 \\
\hline 9. M. O. & -2.4 & 2.1 & 2.0 & 1.3 & 0.2 & -2.2 \\
\hline 10. R. Z. & 4.4 & 7.4 & 2.1 & 0.8 & 1.2 & -2.7 \\
\hline 11 - R. S. & -1.3 & 1.2 & -3.5 & -1.4 & .0 .2 & -4.1 \\
\hline 12- T. D. & -1.3 & -6.6 & -1.7 & 0.5 & 1.1 & 3.5 \\
\hline 13. V. F. & 1.4 & 0.3 & 5.0 & 0.7 & 0.9 & 0.6 \\
\hline 14. W. S. & -5.1 & .5 .2 & 0.6 & 1.9 & 0.1 & 2.1 \\
\hline Nome paciente & $\begin{array}{l}\text { LMM- } \\
\text { EIPTM }\end{array}$ & $\begin{array}{l}\text { LMDI- } \\
\text { EIPTM }\end{array}$ & PDMI-PCM & PDMS-PCM & LMDI-EIMI & LMM-EIMI \\
\hline 1. B. E. & 1.8 & -0.3 & -1.3 & 3,7 & 0.7 & 1.3 \\
\hline 2. E. S. & -6.3 & .7 .4 & 3.2 & 2,1 & -0.1 & 0.6 \\
\hline 3. G.T. & -1.7 & -4.1 & 6.4 & 1,4 & 3.0 & 4.5 \\
\hline 4. G. C. & .0 .9 & -1.0 & 2.1 & 2,6 & 1.9 & 2.2 \\
\hline 5. I. C. & 2.3 & 0.6 & 0.3 & 3,8 & -1.2 & 0.5 \\
\hline 6. J. O. & -1.6 & -1.9 & 2.7 & 2,6 & 1.2 & 1.2 \\
\hline 7. L. S. & 3.9 & 2.1 & 2.7 & 1,8 & 1.0 & 2.8 \\
\hline 8. L. C. F. & 0.0 & -3.0 & 1.5 & 3,4 & 2.0 & 4.6 \\
\hline 9. M. O. & -9.1 & -5.1 & 2.7 & 3 & 1.1 & -3.1 \\
\hline 10. R. Z. & .4 .7 & .4 .8 & 6.8 & 3,4 & .0 .2 & -0.3 \\
\hline 11 - R. S. & .5 .6 & .7 .3 & 5.8 & 2,1 & 3.1 & 3.0 \\
\hline 12- T. D. & 3.5 & 0.6 & 0.0 & 4,3 & 0.0 & 2.7 \\
\hline 13. V.F. & -1.4 & -1.7 & 5.6 & 1,3 & 2.1 & 2.2 \\
\hline 14. W. S. & 2.8 & -1.2 & 2.4 & 1 & -0.5 & 3.4 \\
\hline
\end{tabular}




\begin{tabular}{|c|c|c|c|c|c|c|}
\hline \multicolumn{7}{|l|}{ Tabela A - 5} \\
\hline Nome paciente & $\begin{array}{c}\text { LMDS- } \\
\text { EIMI }\end{array}$ & $\begin{array}{l}\text { LMDI- } \\
\text { EIMS }\end{array}$ & LMDS-EIMS & LMM-EIMS & EIE-EIC & ETE-ETC \\
\hline 1-B. E. & 2.3 & -3.1 & -0.3 & -1.0 & 0.1 & 0.1 \\
\hline 2. E. S. & 3.8 & .4 .4 & -1.0 & -3.4 & 0.1 & 0.2 \\
\hline 3. G.T. & 6.7 & -1.5 & 1.7 & 0.7 & -0.1 & -0.4 \\
\hline 4. G. C. & 4.5 & -2.3 & .0 .3 & .2 .4 & 0.3 & 0.2 \\
\hline 5. I. C. & 1.9 & .4 .4 & -1.6 & -2.5 & 0.6 & 1.7 \\
\hline 6. J. 0. & 3.5 & -3.7 & -1.9 & -3.0 & 1.0 & 1.2 \\
\hline 7. L. S. & 2.3 & 0.6 & 1.8 & 2.4 & -0.7 & -0.1 \\
\hline 8. L. C. F. & 5.3 & -2.4 & 0.6 & 0.5 & 1.0 & 0.5 \\
\hline 9. M. O. & 4.4 & .3 .6 & -0.6 & .7 .6 & 1.0 & 0.9 \\
\hline 10. R. Z. & 2.1 & -1.4 & 0.7 & -1.3 & 0.9 & 0.6 \\
\hline 11 - R. S. & 7.6 & -4.2 & -0.9 & -2.9 & -0.5 & -0.5 \\
\hline 12. T. D. & 3.0 & .4 .0 & -1.1 & -0.9 & 1.3 & 1.2 \\
\hline 13. V. F. & 4.9 & -1.6 & 0.6 & -1.2 & 1.1 & 1.1 \\
\hline 14- W. S. & 3.1 & -2.2 & 0.8 & 2.0 & -1.4 & -0.9 \\
\hline Nome paciente & ETMI-ETE & ETMI-ETC & ETMS-ETE & ETMS-ETC & PCM-LMM & PCM-CMM \\
\hline 1. B. E. & -1.9 & -1.7 & 1.2 & 1.3 & -3.1 & -3.6 \\
\hline 2. E. S. & -1.6 & -1.5 & 3.4 & 3.6 & 2.7 & 5.8 \\
\hline 3. G.T. & .5 .4 & -5.8 & -0.2 & -0.6 & 1.0 & 0.7 \\
\hline 4. G. C. & -3.0 & -2.8 & 1.9 & 2.1 & -0.4 & 0.8 \\
\hline 5. I. C. & -3.5 & -1.8 & 0.9 & 2.6 & -1.0 & -1.2 \\
\hline 6. J. O. & -3.3 & -2.1 & 2.2 & 3.3 & 1.1 & 4.3 \\
\hline 7. L. S. & $\cdot 3.5$ & -3.6 & -1.5 & -1.7 & -0.2 & -0.5 \\
\hline 8. L. C. F. & -4.1 & .3 .6 & 0.8 & 1.3 & -3.7 & -0.3 \\
\hline 9. M. O. & -5.1 & -4.2 & -0.1 & 0.8 & 4.9 & 0.4 \\
\hline 10. R. Z. & -5.4 & -4.8 & -0.7 & .0 .1 & 6.5 & 0.9 \\
\hline 11 - R. S. & -3.9 & -4.4 & 3.2 & 2.6 & 2.2 & 3.6 \\
\hline 12. T. D. & -2.5 & -1.3 & -0.6 & 0.5 & .4 .0 & -2.7 \\
\hline 13. V. F. & -5.6 & -4.5 & -1.0 & 0.1 & 3.1 & 3.5 \\
\hline 14. W. S. & -2.8 & -3.7 & -0.2 & -1.1 & -2.0 & 1.5 \\
\hline Nome paciente & POSM & POSMS & ÂPLANOZ & ÂPLOCLUSAL & ÂPLANTEG & DESMAND \\
\hline 1. B. E. & 2.7 & 5.1 & 91.0 & 92.3 & 92.7 & -0.1 \\
\hline 2. E. S. & 0.6 & 1.6 & 91.0 & 92.4 & 90.6 & -1.5 \\
\hline 3. G.T. & -3.3 & .0 .8 & 90.2 & 92.5 & 91.4 & 0.5 \\
\hline 4. G. C. & -3.3 & -2.1 & 90.4 & 89.5 & 90.6 & 2.4 \\
\hline 5- I. C. & 0.9 & 1.9 & 89.6 & 89.9 & 90.2 & 3.0 \\
\hline 6. J. O. & 1.5 & 3.3 & 89.9 & 90.8 & 88.9 & 4.2 \\
\hline 7. L. S. & 1.4 & 3.3 & 90.9 & 89.7 & 90.2 & 0.7 \\
\hline 8. L. C. F. & -2.1 & 0.4 & 89.0 & 88.6 & 90.2 & 2.2 \\
\hline 9. M. O. & -2.4 & -1.4 & 92.7 & 88.2 & 89.2 & 4.0 \\
\hline 10. R. Z. & -2.5 & -0.3 & 89.6 & 91.2 & 91.1 & 0.6 \\
\hline 11 - R. S. & -1.9 & .0 .6 & 90.2 & 89.1 & 83.6 & 3.0 \\
\hline 12- T. D. & -0.9 & -1.5 & 89.5 & 89.9 & 90.3 & 1.8 \\
\hline 13. V. F. & -0.1 & 0.4 & 89.4 & 90.7 & 88.0 & 4.4 \\
\hline 14. W. S. & -0.2 & .0 .4 & 90.5 & 91.5 & 90.7 & 1.4 \\
\hline
\end{tabular}




\begin{tabular}{|c|c|c|c|c|c|c|}
\hline \multicolumn{7}{|l|}{ Tabela A - 6} \\
\hline Nome paciente & A1 & B1 & $\overline{\text { ÂANT }}$ & DISTZ & DISTCO & DISTZA \\
\hline 1- B. E. & -0.6 & 2.0 & -1.0 & .2 .0 & -11.6 & -10.1 \\
\hline 2. E. S. & -2.2 & 1.5 & 0.6 & -2.7 & 2.8 & 2.6 \\
\hline 3. G.T. & .0 .9 & 2.1 & 0.4 & -0.6 & 2.4 & 2.3 \\
\hline 4. G. C. & 0.6 & 2.2 & -2.3 & -1.3 & -5.4 & .8 .4 \\
\hline 5. I. C. & -1.9 & 1.5 & -3.8 & 0.7 & 1.3 & -0.4 \\
\hline 6. J. 0. & -0.5 & 2.2 & -4.5 & 1.0 & 0.7 & 0.1 \\
\hline 7. L. S. & 0.0 & 1.4 & -5.7 & -1.0 & 0.3 & -0.4 \\
\hline 8. L. C. F. & -0.2 & 2.5 & -1.8 & 2.5 & -4.4 & -2.3 \\
\hline 9. M. O. & -0.7 & 1.5 & -9.2 & .3 .2 & -8.5 & -8.9 \\
\hline 10. R. Z. & 0.4 & 1.6 & 2.5 & -1.0 & 7.9 & 2.4 \\
\hline 11 - R. S. & -0.2 & 3.8 & .7 .2 & -1.2 & -0.5 & -2.6 \\
\hline 12. T. D. & -0.2 & 3.1 & -0.1 & 0.5 & -4.1 & -5.2 \\
\hline 13. V. F. & 0.0 & 2.2 & -6.8 & 4.9 & -12.4 & -10.0 \\
\hline 14. W. S. & -1.1 & 1.3 & -9.1 & -0.6 & -1.2 & -8.0 \\
\hline Nome paciente & DISTNC & DISTJ & DISTAG & ALT $\underline{6}$ & CO-AG & CO-ME \\
\hline 1. B. E. & -5.7 & -5.3 & -5.4 & -3.1 & -8.2 & .7 .5 \\
\hline 2. E. S. & -0.5 & .0 .9 & 0.6 & -0.3 & 2.8 & 3.3 \\
\hline 3. G.T. & 0.2 & 1.2 & 1.3 & -1.2 & -4.3 & 0.3 \\
\hline 4. G. C. & -1.7 & -3.7 & -5.1 & -6.5 & -2.1 & -0.7 \\
\hline 5.।. C. & 1.2 & 1.1 & 1.8 & -2.2 & .0 .5 & 3.3 \\
\hline 6. J. 0. & 1.2 & 0.3 & -1.6 & 0.2 & 0.8 & 3.6 \\
\hline 7. L. S. & -0.2 & .2 .7 & 1.1 & 3.9 & 1.2 & 2.9 \\
\hline 8. L. C. F. & 0.9 & 3.1 & -1.3 & 0.5 & .4 .5 & .3 .6 \\
\hline 9. M. O. & -6.7 & .7 .4 & -10.1 & 0.0 & 1.8 & 2.2 \\
\hline 10. R. Z. & 0.9 & 0.9 & 3.6 & -2.7 & -0.8 & 4.3 \\
\hline 11 - R. S. & -0.8 & -1.1 & -2.3 & -2.3 & 8.6 & 0.8 \\
\hline 12. T. D. & 0.4 & -0.7 & -2.2 & -2.1 & -1.2 & -0.9 \\
\hline 13. V. F. & 2.2 & -2.3 & -6.6 & -4.3 & 1.1 & -2.8 \\
\hline 14. W. S. & -0.3 & -1.7 & 2.6 & -3.2 & -2.8 & 0.2 \\
\hline Nome paciente & ME-AG & DESVENA & PDMI-ETPTM & $\begin{array}{l}\text { PDMS- } \\
\text { ETPTM }\end{array}$ & PDMI-EIPTI & DMS-EIPTM \\
\hline 1- B. E. & 0.9 & 1.4 & 1.5 & -1.3 & 3.8 & 3.7 \\
\hline 2. E. S. & 0.4 & 0.8 & 5.9 & 1.2 & .5 .6 & .3 .6 \\
\hline 3. G.T. & 4.7 & 0.6 & 5.6 & 0.4 & .3 .3 & .2 .8 \\
\hline 4. G. C. & 2.5 & 1.0 & 2.5 & -2.0 & -1.7 & -0.2 \\
\hline 5. I. C. & 6.0 & -0.3 & 0.0 & -4.0 & 3.0 & 4.2 \\
\hline 6. J. O. & 5.1 & 0.1 & 2.2 & -2.8 & -2.5 & -0.8 \\
\hline 7. L. S. & 4.8 & 1.1 & 0.6 & -1.1 & 4.1 & 2.9 \\
\hline 8. L. C. F. & 1.5 & -0.6 & 7.5 & 2.9 & 0.2 & 2.0 \\
\hline 9. M. O. & 4.5 & 2.9 & 5.6 & 0.4 & -5.2 & .2 .8 \\
\hline 10. R. Z. & 4.5 & -0.2 & 4.0 & -0.6 & -2.8 & -6.0 \\
\hline 11 - R. S. & -5.1 & -0.1 & 7.2 & 0.4 & .8 .3 & -4.1 \\
\hline 12. T. D. & 0.3 & -0.6 & 1.0 & -0.8 & 3.4 & 8.3 \\
\hline 13. V. F. & -1.5 & -0.6 & 2.6 & -1.0 & -2.8 & -0.7 \\
\hline 14. W. S. & 7.5 & 1.0 & 2.2 & -0.3 & 1.4 & -0.2 \\
\hline
\end{tabular}


Tabela A - 7

\begin{tabular}{lcccc}
\hline Nome paciente & ETPTM-ETC & ETPTM-ETE ETMI-ETPTM & ETMS-ETPTM \\
1. B. E. & -0.1 & -0.3 & -1.6 & 1.4 \\
2. E. S. & 4.8 & 4.7 & -6.3 & -1.3 \\
3. G.T. & -0.2 & 0.2 & -5.5 & -0.4 \\
4. G. C. & 0.0 & -0.3 & -2.8 & 2.2 \\
5. I. C. & -1.8 & -3.5 & 0.0 & 4.4 \\
6. J. O. & 0.4 & -0.8 & -2.5 & 3.0 \\
7. L. S. & -2.9 & -2.8 & -0.7 & 1.2 \\
8. L. . . F. & 4.3 & 3.8 & -7.9 & -3.0 \\
9. M. O. & 1.2 & 0.3 & -5.4 & -0.3 \\
10. R. Z. & -0.6 & -1.2 & -4.1 & 0.6 \\
11. R. S. & 3.1 & 3.6 & -7.5 & -0.5 \\
12. T. D. & -0.4 & -1.5 & -1.0 & 0.9 \\
13. V. F. & -1.2 & -2.3 & -3.3 & 1.3 \\
14. W. S. & -1.5 & -0.5 & -2.2 & 0.3 \\
\hline
\end{tabular}

